

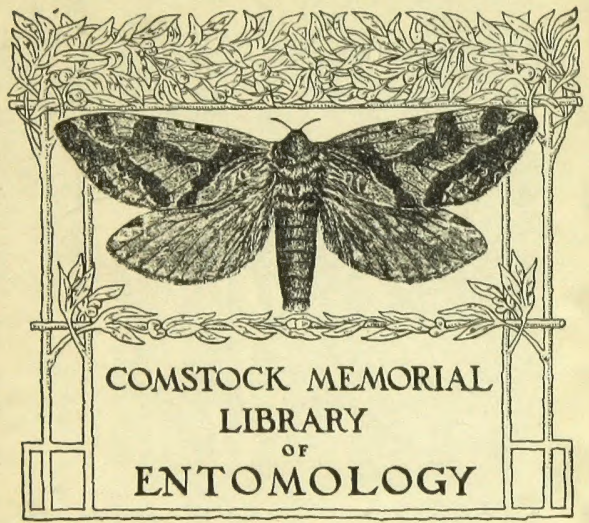

BOUGHT WITH THE INCOME OF THE COMSTOCK ENDOWMENT FUND,

THE GIFT OF JOHN HENRY COMSTOCK AND THE STUDENT MEMORIAL FUND, GIFT OF STUDENTS IN ENTOMOLOGY 


\section{Date Due}

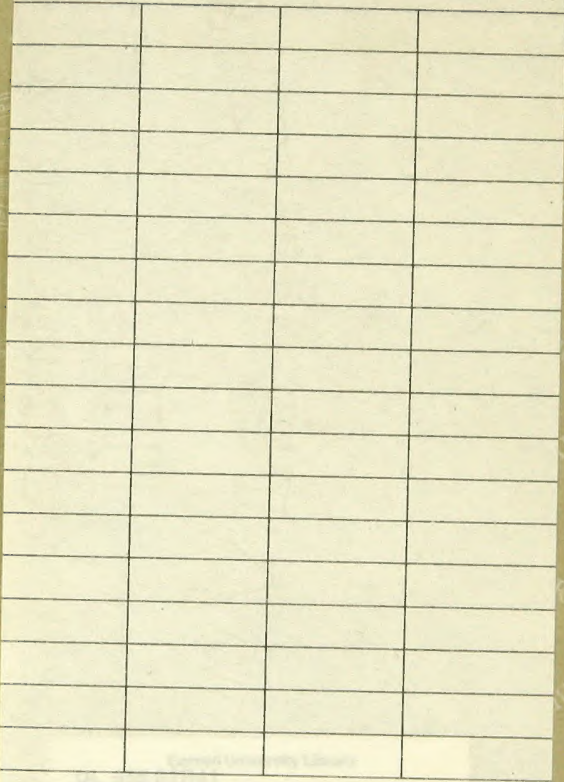

Library Bureau Cat, No. 1137

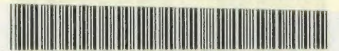







\title{
A CONSPECTUS
}

OP

\section{BUTTERFLIES AND MOTHS.}

\author{
\&c. \&c. \&c.
}


In a forward state of preparation,

\title{
A SERIES OF POCKET VOLUMES,
}

UNIPORM WITH THE

\section{CONSPECTUS OF BUTTERFLIES AND MOTHS.}

\author{
ON ALL THE OTHER PARTS OF
}

\section{Britisf Datural Wistory,}

\begin{abstract}
SAYELY
Botany (with an Alphabet).

Birds (with an Alphabet).

Two-winged Flies, from Meigen and Fallen.

Bees, Wasps, Ants, \&c., from Jurine, Latreille, and Gravenhorst.

Beetles, from De Jean, \&c.

Lace-winged Flies.

Shells and Shell-fish (with an Alphabet).

Minerals (with an Alphabet).

Fossil Remains (with an Al. phabet).

Fishes (with an Alphabet).

Reptiles (with an Alphabet).

Mammalian Quadrupeds (with an Alphabet).

Spiders and Mites (with an Alphabet).

Stars and Constellations (with an Alphabet).
\end{abstract}

Just published, price $2 s$.

AN

\section{$\triangle$ LPHABET OF INSECTS,}

POR THE USE OF BBOINNERS.

W12น КUMEROU: WOOD-CUT.

BY JAMES RENNIE, M.A. 


\section{A CONSPECTUS}

OF THE

\section{BUTTERFLIES AND MOTHS}

\section{FOUND IN BRITAIN.}

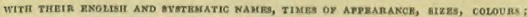

THETF CATEBPILIATE, AND VASLOU LOCALITIES,

\section{BY JAMES RENNIE, M.A.}

Professor of Zoology, King's College, London; Author of "Iasect Architocture," \&c.

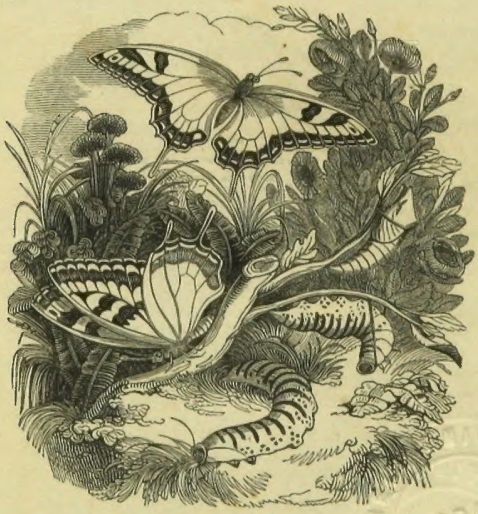

The Queen Butterfiy in itu various stagen.

\section{LONDON :}

WILLIAM ORR, 14, PATERNOSTER ROW, MDCccxxxII. 


$$
\begin{aligned}
& \text { QL Ent } \\
& 555 \text { Ent } \\
& \text { G7 } \\
& \text { K41 }
\end{aligned}
$$

C. 5501 


\section{PLAN OF THE WORK.}

TiLe the task is performed by some person more competent than I can have any pretensions to be, this little volume is intended to assist those who study insects philosophically, in ascertaining the species of our native butterfies and moths; while it may be useful also to those employed in the suborchnate pursuits of making collections either for profit, or as innocent and pretty toys.

In order to render the descriptions plain, I have avoided as much as possible the use of terms not intelligible to a gencral reader, decming it an outrage upon common sense, to invite a student to a museum filled with the most beautiful productions of Creative Wisdom, and at the same time taking some pains to fill the rooms with sinoke before he is introduced, with set purpose to hind him and cause him to stumble. Though this may appear preposterous enough, it has long been the prevailing fashion, particularly in Natural History, which was in consequence for many years rendered unpopular, and has been thrown immensurably behind in the 
rapid progress recently made in other branches of knowledge, naturalists having obviously acquired an artifieial taste for the șmoke. The chief glory of our modern naturalists appears to be the discovery of species, which, to wse their cant phrases, may be "new to seience," or " "n addition to the British Fauna,"-the term Fauna heing generally and most inaccurately applied to fishes, shells, and other productions, of a certainty not under the dominion of the goddess of the woods and rields; no more than mushrooms and sea-weeds, which have no Hlower, are under the dominion of Flora. The term Kingdom, in the phrase animal, vegetable, and mineral kingulom, together with Tribes, Families, and the like, is founded on quaint and inaceurate fancies of the same kind, which would not be tolerated in any other branch of science or literature.

In describing species, either well known or " new to our Fanna," or "our Flora," the current style, misnamed scientific, may be fairly characterised as a uniform tissue of pedantic barbarisms, devised, it would appear, not for the diffusion, but the concealment of knowledge. If the descriptions affect to be in English, the language employed is most assuredly not English. Thus we have "favous" and "luteous" for "yelluw," "griscous" for grey, "fuscous" for " dusky ;" while similar words are not only compounded with Latin derivatives, as "Ochraceous-fuscous," meaning, I conjecture, "dusky-buff," but with plain English, such as 
"castaceous-red," "hoary-griseous," " griseous-rosy," "rusty-testaceous," and numerous others, equally offensive to good sense and correct taste. We meet also with such phrases as "a very obsolete spot," "a cineruscent striga totally oblitcrated," the meaning of which I do not pretend to be able to decypher, as my eyes are not acute enough to perceive what is "obsolete" or "totally obliterated," much less to sce its colour. If I had room I could exemplify this in many other things than colour-such as "striguted" for "streaked;" besides the use of Latin words innumerable, without alteration, where English words would be inore expressive.

But with all this affectation of mongrel Latin so bayharously mixed up with English, the writers seem to have but a very scanty knowledge of Latin itself; for when the descriptions pretend to be in Latin, all grammar is set at defiance, and it is no more Latin than the other is English, it being no very uncommon occurrence to meet with such phrases as "ad stigmatibus fluris," "litura interjecto," "puncto ocellaris," "stigmâ anticû," "stigmata sita ;" and similar ungrammatical language, such as would not even have been blundered upon by a schoolboy.

Science can never be benefitted by terms and language of this sort, while it is out of all question thereby degraded and confined to a narrow circle, beyond which it can only be extended by simple terms and plain lan- 
guage, such as are used in other departments of human knowledge.

In consequence of the materials which I was obliged to use, I have not succecled altogether according to my wishes, in simplifying the following descriptions; but I trust there are so few of the stumbling blocks left, that the student may casily surmount them.

The groundwork of the description of British butterflies and moths was first laid by Mr. Haworth, who has certainly not been surpassed in minute accuracy by any of his followers, most of whom have borrowed largely fiom him without acknowledgment. I owe him my best thanks for the loan of the third part of his valuable work, (nnw out of print, and very scarce,) which he most liberally granted through the medium of my friend Mr. Loudon, the distinguished author of what I always call the miraculous "Encyclopedit of Plants." The materials taken from this part are uniformly marked by inverted commas; but I deem it duc to the author to state, that even where these marks do not occur, by far the larger portion of this little volume is a free translation from his Latin.

Next to Mr. Haworth, I have been indebted to the works of Mr. Stephens, more particularly his "Systematic Catalogue," the names and order of which I hare, with a few exceptions, implicitly followed; and I cannot too strongly recommend every person engaged in the study of British insects to procure a copy of this 
very useful book. I have ventured to give names different from his, to the greater divisions of the Moths, not that mine are unobjectionable, though they do not, 1 hope, involve the Hibernian discrepancy of including day-flying species under a night-flying division, as $\mathbf{M}$. Latreille's certainly do,- one of the beauties, I suppose of what is falsely called the natural system.

The work of Mr. Curtis is also highly valuable, from the accuracy of the engravings and the novelty of the subjects, of which I have taken occasional advantage as I proceeded.

In all cases when I either possessed specimens, or had access to them, I have not failed to compare the descriptions of authors with the insect itself, in order to arrive at as much accuracy as possible; and though I am far from thinking that I have fallen into no errors, 1 trust such as may be discovered will be found trivial in comparison with the utility at which I have aimed. I shall take it very kindly if lists of any such errors, or information connected with the subject of this, or my other projected volumes, be sent to me, free of expense, to the publisher's.

In pursuance of my plan of publishing cheap and comprehensive pocket volumes like the present, I am already considerably advanced with the "Conspectus of Botany," that of "Birds," and that of "Two-rvinged 
Flies," which will be accompanied with "Alphabets for Beginners," uniform with the "Alphabet of Insects."

I have also for many years been collecting from observations in the fields, as well as from reading, the most interesting facts connected with the manners and economy of our native animals; and relative to those described in this little Work, I have already materials for a small volume, which I intend to arrauge for publication under the title of "Biography of British Butterflies and Moths."

\section{JAMES RENNIE.}

Lee, Kent, 10th June, 1832. 


\title{
SYSTEMATIC TABLE
}

\author{
OP
}

\section{BUTTERFLIES AND MOTHS.}

\section{LEPIDOPTERA (LINNאUs).}

INSECTs with four membranaceous ribbed or veiny wings clothed on both sides with minute scales, like meal or powder, placed like slates or tiles, and easily rubbed off. Mouth, with a spiral hollow sucker (haustellum) placed between two palpi clothed with hairs or scales; the body hairy; the corselet with a tippet (tegula) on each side; foot (tarsus) with five joints; the antenne with a great number of joints.

\section{Divided into \\ I. Butterflies; ir. Мoths.}

I. BUTterflies (Papiliones, Scheiffermulez ). Antemne, diverging at a considerable angle from the base, thickest towards the tip, which is either rounded in the form of a club, or flattish and ending in a hook or bristle; wings, when at rest, mostly erect and destitute of any bridle to retain the upper pair in their place.

\section{Divided into}

1. Papilionide; 2. Nympintide; 3. Lycenide; 4. Hesperide,

II. MOTHS (Pialane, Ray, not Linnjeus). Antenna more or less tapering; wings, during repose, horizontal 
or deflected, with a bridle formed of a horny bristle, or a bundle of hairs from the under pair, through a fold or ring to the upper pair, which are thus kept in their position.

\section{Divided into}

1. Sphungina ; 2. Bombycina ; 2. Noctusna; 4. GloMETRINA ; 5 . 'TORTRICINA.

\section{BUTTERFLIES (Papiliones)}

Divided into

1. Papirionine, with the fore legs long, and the tips of the antenno without any hook

2. Hesperide, with the fore legs long, and the tips of the antennæ with a hook

3. NYMPHALIDE, with the fore legs somewhat short, and the claws of moderate size, forked or with only one nail

4. Lrcenide, with the fore legs somewhat short, and the claws minute and not forked

\section{PAPILTONIDN (LEACH).}

Antenne with the club-shaped tip, in some flattish, and in no case with any hook; legs long with claws, in some forked, in others not; hinder shanks (tibice) with a single pair of spurs; under wings with groove or scollop to receive the abdomen; all the wings erect during repose

\section{Divided into}

1. Papilo, with the clubbed tips of the antenna longish and not flattish, and the under wings not angular

2. Goneptenyx, with the clubbed tips of the antennx short and not flattish, and the under wings angular.

3. Corns, with the clubbed tips of the antennre not flattish and the under wings roundish, with a groove to receive the abdomen

4. Pinfrs, with the clubbed tips of the antenna flattish, and the wings sparingly covered with scales and somewhat translucent 
5. Ponrn, with the clubbed tips of the antenna flattish, and the wings plentifully covered with scales, the upper wings with three corners, the under wings not variegated beneath

6. Manciprom, with the clubbed tips of the antennæ flattish, and the wings plentifully clothed with scales, the upper wings distinctly round at the tip, the under wings variegated beneath

7. LevCopHasia, with the clubbed tip of the antenna flattish, and the wings plentifully covered with scalez, the upper wings somewhat oval

\section{NYMPIIALIDAE (SwAINSON).}

Antenna with the club-shaped tip in some very flat, in others without any hook at the tip; fore legs in both sexes somewhat short, the hind legs long, in some with forked claws, in others with only one nail; under wings with a groove to receive the abdomen

\section{Divided into}

1. Nemzoвn's, with the clubbed tips of the antenne abrupt, the eyes naked; the palpi very short

2. Mristas, with the clubbed tips of the antenna ab. rupt, the eyes naked, the palpi longer than the head, and the under palpi very hairy

3. Aroynsis, with the clubbed tips of the antenna abrupt, the eyes naked, palpi longer than the head, and the under palpi scarely hairy

4. Comsa, with the clubbed tips of the antenna abrupt, the palpi with scales and few hairs; the upper wings narrow, with a waved border, the under wings indented with a distinct tail

5. Vanıss.1, with the clubbed tips of the antenna ab. rupt, the cyes downy, palpi hairy with few scales, and the upper wings angular, the under wings with a short tail .

6. Aminasis, with the clubbed tips of the antennac abrupt, the eyes downy, palpi with a few hairs, thickly clothed with seales, the upper wings angular, the under wings round, indented, and without any tail 
7. Cysruts, with the clubbed tips of the antenna abrupt, the eyes downy, and the upper wings not angular - 10

8. Apatura, with the antenna gradually thicker, and the clubbed tips straight; the eyes naked

9. Limexitrs, with the antennx gradually thicker, the clubbed tips straight, the eyes hairy

10. Hrpparcirs, with the antenna gradually thicker, and the clubbed tips more or less curved

\section{LYCXNIDAE (LEACH).}

Antenna, with the club-shaped tip in some flattish, in others not having a minute hook at the tip; fore legs rather short; hinder shanks with a single pair of spurs at the points; under wings with a groove to receive the abdomen

\section{Divided into}

1. Trecrs, with the clubbed tips of the antenne not flat, and the eyes downy

2. Lycasa, with the elubbed tips of the antenna not flat, and the eyes naked flattish

3. Polyosmarus, with the clubbed tips of the antenna

\section{IIESPERIDAE (SWAINSON).}

Antenne, with the clubbed tip spindle-shaped in most instances, with a hook at the point; legs long; hinder shanks with two pairs of spurs, one pair in the middle and one at the point; claws very small; under wings with a groove to receive the abdomen

\section{Divided into}

1. TIYMELE, with the clubbed tip of the antennx curved inwards

2. Pampinzs, with the clubbed tip of the antenna straight or very slightly surved 
MOThS (Phalent, Iray).

Divided into

PAOE

J. SPIIINGINA (RENIE). Antenuce tapering into a club, in form of a prism or of a spindle, sometimes peckinated or serrated, and often with a tuft of hair or scales at the tip; wings horizontal, in many transparent, with few or no scales on the disc, the first pair much the longest; tail sometimes in form of a brush

\section{Divided into}

1. Zyganide; 2. Stungide; 3. Srstide; 4. EerRISDE.

II. BUMBYCINA (RENIE). Antenne more or less fringed or serrated, particularly in the males; palpi round and short; jaws and tongue very short (in some wanting), and not spiral; wings undivided and with three corners; body large ; tail frequently woolly

\section{Divided into}

1. Herlaliba; 2. Notodontide; 3. Bomuycida: 4. Anctirde.

111. NOCTUINA (REnns). Antenne in the males fringed, and in a few pectinated or serrated ; palpi flattish with the second joint large, and the tip short; jaws in most long and never wanting ; wings undivided, somewhat three cornered, in most deflected or incumbent, in some horizontal; corselet frequently with a crest; tail in the males tufted

\section{Divided into}

1. Lithoshde; 2. Noctuide.

IV. GeOMETRINA (Rennie). Antenna either pectinated or plain; palpi short, roundish, generally with three joints; jaws short and membranaceous, sometimes wanting ; wings large, undivided and horizontal, or nearly so, during repose; corselet velvety or scaly, never crested or tufted; tail of the male with a small tuft. 


\section{Divided into}

1. Geometridñ; 2. P'latyptericide; 3. Pyralide.

V. TORTRICINA (RENIE). Antenna either distant or near at the base, in some very long, often pectinated or bearded in the males: pulpi rounded, velvety or scaly; wings entire in some, divided in others

\section{Divided into}

1. Tortricide; 2. Ypononeutide; 3. Trnelde; 4. Azuctidis.

\section{SPIIINGINA (RENNIE).}

Divided into,

1. ZYOANIDE, with the antenne spindle-shaped, without a bundle of scales at the tip; palpi long; abdomen ending in a small tuft; wings covered with powdery scales

2. Sringmis, with the antennx prism-shaped, tipped with a scaly bristle, or naked; palpi short; abdomen not ending in a tuft

3. SessuDE, with the antennce prism-shaped, having a slight look and a slanting scaly projection at the tip; pulpi short ; abdomen ending in a tuft

4. Egernos, with the antenne spindle-shaped, and tipped with a plume of scales; palpi long; eyelets two very minute behind the antenne; abdomen ending in a tuft ; wings most frequenily transparent.

\section{ZYGANIDAE (LеACH).}

\section{Divided into}

1. Iso, with the antenna either doubly pectinated, or simple and not curved

2. $\Lambda$ мтиносев $\wedge$, with the antenna having an abruptly curving club at the tip 


\section{SPIIINGIDA (LEACH).}

Divided into

1. Surarntuus, with the wings more or less irregular $r$ indented

2. Achenonts, with the wings entire and acute; the aws short.

3. Sruisx, with the wings entire and acute; the jaws bngish; and the antennx not clubbed at the tip

4. Dencepuse, with the wings entire and acute; the aws longish; and the antennx clubbed at the tip $\quad 25$

SESSIID R. (StEPHENS).

\section{Divided into}

1. Macnoglossa, with the wings clothed with scales and opaque.

2. SEsta, with the wings naked and their disc transparent.

\section{AGERIIDAE (STEPUENs).}

\section{Divided into}

1. Trocurium, with the jaws very short, and the antenna shortish

2. Xigen 1 , with the jaws and antenna longish

\section{BOMBYCINA (RENNIE.)}

\section{Divided into}

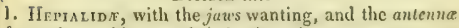
in form of a necklace, or bristle-shajed

2. Bombxcid $\pi$, with the jaws wanting, and the antenna for the most part doubly pectincate

3. Notononids:, with juws more or less obvious but tery short

4. Arctid ., will the jaus more or less obvious, short, nd somewhat membranaceous.

\section{IIEPIALIDA (STEPHENS).}

\section{Divided into}

1. IIfrunus, with the antonne somewhat thread-like and aruch shorter than the corselet 
2. Cossus, with the antenna bristle-shaped, as long as the corselet, with the tip indented on the inside

3. ZnUzERA, with the antenna bristle-shaped, as long as the corselet, with the tip not indented

\section{NOTODONTID $L$ (StepHeNs).}

\section{Divided into,}

1. Pygers, with the corsclet crested, the wings denticulated

2. Crosters, with the corselet crested; the wings entire; the antenna short and curved

3. Lissuss, with the corseleterested; the wings entire; the antenne somewhat longish and straight

4. Crnuti, with the corselet not crested; the wings longish and somewhat translucent

5. 1'ctasia, with the corselet not crested; the wings longish, opaque, with the scales not elevated

6. Srauropus, with the corselet not crested; the wings longish, opaque, with the scates elevated

7. ENDnosis, with the corselet not crested; the wings shott, broad, and somewhat triangular

8. Pribopuona, with the wings hairy, and entire at the tip .

9. Prniprt, with the wings scaly, entire at the tip and somewhat translucent

10. Cusovs, with the wingsscaly, entire at the tip and opaque

11. Notononts, with the corselet not crested; the tip of the wings more or less denticulated, having one indentation on the back, first pair slightly long with the tip blunt

12. Inrocumpi, with the corselet not crested; the tip of the wings more or less denticulated, and having one indentation on the back, first pair longish with the tip rather acute

13. Lомиогтгх, with the corselet crested; the tip of the wings more or less denticulated, and having one indentation on the back

14. I'JELos' om, with the tip of the wings more or less denticulated, having two indentations on the back 


\section{BOMBYCYD.F (STEPHLXS).}

\section{Divided into}

1. Arisin, with the second pair of wings entire, -all theyed spots; each joint of the antenna being singly anched or toothed

2. Sarvanis, with the sccond pair of wings entire,I with eyed spots; each joint of the antenna being doubly anched or toothed

3. Hewlocsuss, with the second pair of wings entire, all without eyed spots; the first pair somewhat transluat, and longish with no central spot

4. Enoonsmen, with the second pair of wings entire, I without eyeci spots; the first pair somewhat translucent, dongish, with a central white spot

5. LAsıocımPA, with the second pair of wings entire, I without eyed spots; opaque and somewhat shortish, steriorly rounded; the tail slightly hairy . 6. Tinrcuruns, with the second pair of wings entire, I without cyed spots; opaque and somewhat shortish, teriorly rounded; the tail very hairy; the antenure might

7. Cхитнослмpa, with the second pair of wings entire, ll without eyed spots, opacque and somewhat shortish, steriorly rounded; the tail very hairy; the antennac mewhat curved

B. Ctisiocsures, with the second pair of wings entire, without cyed spots; opaque, somewhat shortish, posteorly somewhat abrupt and rather acute

9. Lutrín nticulated ; the palpi rather short

10. ODoxrsts, with the secont pair of wines more or ss denticulated; the palpi longish ; the first pair of wings lire

11. Gastroracin, with the second pair of wings more less denticulated; the palpi longish; the first pair of ngs indented 


\section{ARCTIIDAE (LEACH).}

\section{Divided into}

1. Fumes, with the jaws indistinct; the wings not sealy, more or less translucent, rounded and very hairy

2. Psycure, with the jaws indistinct; the wings not scaly, more or less translucent, longish and rather acute .

3. Printuopmara, with the jaws indistinct; the wings more or less translucent, and clothed with minute scatterod scales.

4. IIrpogyma, with the jaws indistinct; the wings opaque and thickly scaled: the antenna pectinated or fringed; the fore feet slightly hairy, and rather slender; the first joint of the palpi minute

5. Psilura, with the jaws indistinct; the wings opaque and thickly scaled; the antenne pectinated or fringed; the fore feet slightly hairy and rather slender; and the first joint of the palpi longish and clubbed

6. Dasycura, with the jaws indistinct; the wings opaqque and thickly scaled; the antenne pectinated or fringed; the fore feet very hairy and thick; and the wings t longish

7. ORGXIA, with the jaws indistinct; the wings opaque and thickly scaled; the antenna pectinated or fringed; the fore feet very hairy and thick ; the wings shortish, triangular, and wanting in the female

8. HETEROGENA, with the jaws indistinct; the wings more or less opaque and thickly scaled; the antenna simple; the wings triangular and posteriorly somewhat abrupt

9. Lisacomrs, with the jaws indistinct; the wings opaque and thickly scaled; the antennx simple; the wings longish and posteriorly rounded.

10. Colocissa, with the jaws distinet and slightly longer than the head; the wings opaque and thickly scaled; the corselet crested

11. Ancris, with the jaws distinct and slightly longer than the head; the wings opaque and thickly scaled; the corselet not crested; the body ringed or spotted ; the first joint of the palpi longer than the second, and third joint rather acute 
12. Sptzosoma, with the jaws distinct and slightly onger than the head; the wings opaque and thickly caled; the corselet not crested; the body ringed or ipotted; the first joint of the palpi longer than the second, ind the third joint short and oval

13. Eutucmosia, with the jaws distinct and slightly longer than the head; the wings opaque and thickly scaled; the corselet not crested; the body ringed or spotted; the first joint of the palpi shorter than the second, find the third joint cylindrical

14. Nemeorturs, with the jaws distinet and slightly longer than the head; the wings opaque and thickly tcaled; the corselet not crested; the body ringed or spotted; the first joint of the palpi shorter than the second, and the third globose

15. Poвтusis, with the jaws distinct and slightly longer than the head; the corselet not crested; the boty bot spotted, but crested at the tip

16. LALIA, with the jaws distinct and slightly longer than the head; the wings more or less translucent, and thinly clothed with a few scales; the body not spotted; the palpi longish and very hairy.

17. Levcoms, with the jaws distinct and slightly longer than the head; the wings more or less translucent, and thinly clothed with a few scales; the body spotted; the palpi shortish and acute

18. Pinagmatoms, with the joints distinct and slightly longer than the head; the wings more or less translucent, and thinly clothed with a few scales; the body spotted; the palpi scarcely distinct, and hairy

19. DIApuror $\Lambda$, with the jaws distinct and slightly longer than the head; the wings more or less translucent, and thinly clothed with a few scales; the body spotted; palpi distinct and scaly

20. Hymincampa, with the jaws much longer than the head; the wings thickly clothed with scales

21. Nudani, with the jaws much longer than the head; the wings translucent and hairy 


\section{NOCTUINA (Rennie.)}

\section{Divided into}

1. Litnosirds, with the wings very long, most frequently convoluted; and the palpi cylindrical

2. Noctuine, with the utings slightly longish, not convoluted; and the palpi somewhat flat

\section{LITIIOSIID AE (StepheNS).}

\section{Divided into}

1. Evrrirs, with the first pair of wings oblong and somewhat elliptically abıupt; the palpi three-jointed; the jaws rather longer than the head

2. Derrern, with the first pair of wings oblong and somewhat elliptically abrupt, the palpi three-jointed; the jaws much longer than the head; the second pair of wings somewhat transluccot

3. GNornus, with the first pair of wings oblong and somewhat elliptically abrupt; the palpi three-jointed; the jass much longer than the head; the second pair of wings opaque

4. Lrtuosia, with the first pair of wings oblong and somewhat elliptically abrupt; the palpi two-jointed

5. Setina, with the first pair of wings somewhat threecornered and not abrupt; the palpi three-jointed, and having the third joint much shorter than the second

6. CALLIMONIIA, with the first pair of wings somewhat threc-cornered, not abrupt; the palpi three-jointed, and having the third joint nearly equal to the second

\section{NOCTUIDIE (StrPnENS).}

\section{Divided into}

1. Prnopirn, with the body more or less flat; the wings incumbent, and the first pair with the hinder margin entire; the corselet not crested; the palpi recurved

2. Agrotis, with the body more or less flat; the first pair of wings with the hinder margin entire, and having three stigmata; the corselet not crested; the palpi not recurved 
3. Tnirness, with the body more or less fat: the first pair of wings with the hinder margin entire, and having wo stigmata; the corselet not crested; the palpi not recurved

4. Actemin, with the body more or less flat; the first pair of wings narrow, shining, and green; the corselet somewhat crested; the palpi not longish, recurved, nor beak-shaped

5. Xylins, with the body more or less flat; the first pair of wings narrow, dull, wood-coloured; the corselet somewhat crested; the palpi not longish, recurved, nor bcak-shaped

6. GLAA, with the body roore or less flat; the first pair of wings somewhat broad; the corselet woolly, transwerse, and not lobed

7. Amplnpyra, with the body more or less flat; the Fings incumbent, the first pair with the hinder margin potched or indented; the corselet not crested

8. NFNsa, with the body more or less flat; the wings incumbent, the first pair notched; the palpi longish and recurved; the corselet strongly crested

9. Calocame, with the body more or less flat; the frst pair of wings notched; the palpi short; the corselet somewhat crested, distinctly square and posteriorly lobed.

10. Schropreaxx, with the body more or less flat; the wings deflexed, the first pair tooth-notched

11. Enrorus, with the body more or less fiat; and the fist pair of wings slightly notched

12. Euplexia, with the body not flat; the first pair of swings with the hinder margin slightly notehed, folded lengthwise during repose; the second pair entire

13. Prrocopiona, with the body not flat; the first pair of wings with ragged teeth; the second pair entire . 14. PLusis, with the body not flat; the first pair of wings acute, and more or less marked with metallic chaacters : the corselet creted the palpi aseending

15. Dyptengeis, with the body not flat; the wings incumbent, the first pair not folded, and having no metallic marks; the corselet with a forked crest

16. CALorinst, with the body not flat; the wings 
deflexed and banded with green; the corselet with a forked crest

17. Tracuma, with the body not flat; the wings broad and vory slightly notched ; the corselet with a forked crest; the palpi short, projecting forward, with the last joint strongly distinct

18. Pous, with the body not flat ; the wings longish and spear-shaped; the corselet with a forked crest; the palpi short, projecting forwards, with the last joint strongly distinct

19. IIAsa, with the body not flat; the corselet without a forked crest

20. Mamestri, with the body not flat; the palpi with the last joint almost concealed

21. Hexiorhoses, with the body not flat; the corselet somewhat crested; the antenna (in the male) pectinated; the jaws short

22. Chantas, with the body not flat; the first pair of wings having the hinder margin somewhat hooked; the jaws longish; the palpi ascending

23. Valemis, with the body not flat; all the wings narrowish, the hinder margin indented, the first pair posteriorly rounded; the corselet slightly hooded, with an undivided crest; the antenne in both sexes pectinated

24. Miser.IA, with the body not flat; all the wings narrowish, the first pair posteriorly rounded; the antennas simple or slightly serrated

25. XYLoruasia, with the body not flat; the first pair of wings with the hinder margin somewhat abrupt

26. NONAGria, with the body not flat; the first pair of wings with the hinder margin indistinctly notched, and somewhat abrupt; the corselet with an undivided crest and hooded

27. Chantcres, with the body not flat; the first pair of wings with the hinder margin indistinctly notched, and somewhat hooked; the corselet with an undivided crest and hooded

28. Cucumin, with the body not flat; the first pair of wings indented, long, narrow, and acutely spear-shaped; the corselet with an undivided crest and anteriorly hooded 
29. ABrostol.t, with the body not flat; the first pair f wings indented and acute; the corselet with a forked trest; the palpi longish, somewhat slender and ascending

30. AРАмх , with the body not flat; the first pair of 92 wings indented and acute; the corselet with a forked crest; the palpi projecting forward, of moderate length, and somewhat clubbed

31. Morso, with the body not flat; all the wings the binder margin rather deeply indented, of uniform colour and dull

32. CAtocila, with the body not flat; all the wings broad, with the hinder margin rather deeply indented, of yarious colours, the second pair pretty, with a black border

33. TeтreA, with the body more or less thick; all the wings entire, soiled, with the hinder margin incurved, the first pair rather broad, with the hinder margin somewhat hooked

34. XANтma, with the body more or less thick; all the wings entire, and more or less golden yellow

35. Mrthims, with the body more or less thick; all the wings entire, the first pair acute, the fringes of moderate length

36. Culopinsta, with the body more or less thick; all the wings entire, the first pair somewhat rounded, with the fringes longish

37. Trтлtra, with the body more or less thick; all the wings entire, the first pair broader, with the tip acute ; the palpi projecting forwards and distant; the corselet with a forked crest posteriorly

38. Dipirtien A, with the body more or less thick; all the wingrs cntire; the first pair grcenish, variegated with black, the second pair dull

39. Cenico, with the body more or less thick; all the wings entire, the first pair duskyish, the second pair yellowish.

40. Gontrns, with the body more or less thick; all the wings entire, the first pair narrower, with the tip acute 
41. HADENA, with the body more or less thick; all the wings entire, the first pair narrower, with the tip blunt; the fringes short

42. Envaronis, with the body more or less thick; all the wings entire, the first pair narrower, with the tip blunt, the fringes longish .

43. Rusixs, with the body more or less thick; all the wings entire, the first pair rather broad, with obscure stigmata; the corsclet somewhat crested

44. Grarumona, with the body more or less thick; all the wings entire; the first part rather broad, with three indistinct stigmata

45. Canapnina, with the body more or less thick; all the wings entire; the first pair narrow; the palpi with the last joint almost concealed

46. MIANA, with the borly more or less thick; all the wings entire; the first pair narrow; the palpi with the last joint very distinct

47. Bryopisis , with the body more or less thick; all the wings entire; the first pair rather broad, blunt, the hinder margin round, pale, variegated with black; the corsclet crested, and not scaly

48. Srguts, with the boily more or less thick; all the wings entire; the first pair rather broad, soiled, fringes short; the corselet not crested, and scaly.

49. Ilrtomus, with the body more or less thick; all the wings entire; the first pair rather broad, acute, somewhat unequally dilated ; the palpi ascending; the corselet not crested, and scaly

50. Crmatonom, with the body more or less thick; all the wings entire; the first pair yellowish, netted with tawny; the palpi not ascending, projecting forwards, with the last joint acute

51. Cosma, with the borly more or less thick; all the wings entire; the first pair reddish, with a darker central band; the palpi projecting forwards, not ascending, with the last joint acute

52. Acronycta, with the body more or less thick; all the wings entire; the first pair rather broad; the paIpi with the last joint blunt. 
53. Lyrka, with the body more or less thick; all the sings entire; the first pair narrow, shining, with cross lines

54. Bounrcis, with the body more or less thick; all the wings entire; the first pair narrow, shining, without cross lines; the palpi with the last joint ovally pointed .

55. Scotopirla, with the body more or less thick; all the wings entire ; the first pair narrow, shining; the palpi with the last joint blunt .

56. Granufsia, with the body more or less thick; all the wings entire; the first pair pale, not shining, with eross lines

57. Leveanra, with the body more or less thick; all the wings entire; the first pair narrow, pale, not slining, and without cross lines

58. Cen all the wings entire; the corselet not crested, woolly, or bairy; the antenna thickening or flat

59. Simyra, with the body short ; the first pair of wings Jongish, narrow, and acute; the antenna not thickening.

60. Achatra, with the body short; the first pair of wings longish, narrow, and blunt; the antennx not thickening

61. Orruosis, with the hody short; the first pair of (twings longish and narrow; the palpi very short and hairy, projecting forward, with the last joint almost concealed

62. Srmopnors, with the hody short; the first pair of wings longish and narrow; the palpi very short, very thairy, projecting forward, the last joint almost concealed; exserted, and deflexed

63. Celena, with the body short; the first pair of wings longish and narrow; the palpi very short, very liairy, glexserted, and not deflexed

64. Apatrla, with the body longish

65. BrerHA, with tho hody longish and slender; the wings entire; the palpi so short as to be scareely pera'ceptible

66. Acosimetra, with the body longish and slender; the palpi short, projecting forwards, very slightly ascending, fivith the last joint exserted 
67. ANarts, with the body longish and slender; the palpi short, with the last joint concealed; the second pair of wings yellow, with a black border

68. Strinis, with the body longish and slender; the second part of wings pale, shining, and not ornamented .

69. Aconrts, with the body longish and slender; the first pair of wings rhomboidal, somewhat shining, rather dilated at the base, with the hinder margin roundish; the palpi of moderate length, and ascending

70. Eurunsia, with the body longish and slender; the first pair of wings longest, spear-shaped, shining, somewhat dilated at the base, with the hinder margin rounded; the palpi ascending

71. Evcridis, with the body longish and slender; the first pair of wings rather dilated at the base, with the hinder margin rounded, the tip acute, marked with geometric lines

72. Erastris, with the body longish and slender; the first pair of wings rather dilated at the base, with the hinder margin rounded, the tip acute, and not marked with lines .

73. Ornivss, with the body longish; the first pair of wings not dilated at the base, with the hinder margin repanded, the tip somewhat hooped

74. Puytomerna, with the body longish and slender; the first pair of wings not dilated at the base; roundish, not repanded; the legs simple

75. CAtepuin, with the body longish and slender; the hind feet very hairy, hairs short

76. Scorreopus, with the body longish and slender; the hind feet very hairy, the hairs longish .

\section{GEOMETRINA (RENnIE)}

\section{Divided into}

1. Geometride, with two short palpi ; the first pair of wings not hook shaped; the caterpillars measurers or loopers

2. Platyptencida, with two short palpi; the first pair of wings for the most part hook shaped; the caterpillars not measurers or loopers 
3. Prnation, with two or four longish and large palpi; the caterpillurs in a leafy covering

\section{GEOMETRID E (StLPians.)}

\section{Divided into}

1. Gzonвтлs, with all the wings acutely angular; the body somewhat thick

2. Macaria, with all the wings acutely angular; the first pair notched

3. ENromos, with the first pair of wings deeply notched, and the second pair somewhat angular

4. Ounaprenyx, with the first pair of wings entire or somewhat angular, the second part acutely angular, yellow, with two streaks

5. Culonrssa, with the first pair of wings entire, or somewhat angular, the second pair acutely angular, green, with two pale streaks

6. BRADYEPETIs, with the first pair of wings entire, or somewhat angular, the second pair acutely angular, pale, with a slanting red streak

7. TIMANDRA, with the first pair of wings somewhat angular, the second pair acutely angular .

8. CАп्PNA, with the first pair of wings somewhat, angular, the second pair rounded and someivhat angular green, with pale streaks

9. AN1A, with the first pair of wings somewhat angular, the second pair rounded, somewhat angular, pale with rufous streaks

10. Lunymene, with the first pair of wings somewhat angular, the second pair rounded, somewhat angular, rusty with darker lines

11. Evione, with the first pair of wings having two darker streaks, the second pair rounded with toothed erosions.

12. Pruicallis, with the first pair of wings variegated; the antenna in both sexes pectinated

13. Hrmer , with the first pair of wings somewhat rufous, and thin, having two darker streaks, the second pair round and entire 
14. Crocarrs, with the first pair of wings yellowish, and having a darker band, the sccond pair rounded and entire

15. Vrxirra, with the first pair of wings yellowish, spotted with black

16. InsmтнA, with the first pair of wings entire: the second pair, somewhat angular, green with two pale streaks 10

17. Lipurra, with the first pair of wings entire: the second pair, somewhat angular, pale, with a purple streak or ringlet

18. Eusmersia, with the first pair of wings entire; the second pair powdery with darker streaks .

19. Hals, with the first pair of wings entire; the second pair somewhat angular, powdery, with black letters, but without streaks

20. Odontorers, with the wings not angular, the first pair with toothed erosions, the second pair somewhat indented

21. Lamproptrayx, with the wings not angular, the first pair slantingly streaked, acute, having the hinder margin slightly rounded, and scarcely denticulated; the sceond pair soinewhat indented

22. Scotosia, with the first pair of wings slantingly streaked, acute, and denticulated; the second pair deeply indented

23. HeMznopurta, with the first pair of wings somewhat obtuse, the hinder margin rounded and slightly indented

24. C.мmтовиман, with the first pair of wings streakel or banded across, acute, with numerous ornamental svavings

25. Axricces, with the first pair of wings streaked or banded across, acute, with an insolid band in the middle

26. Eucosur $A$, with the first pair of wings streaked or banded across, and acute; the second pair decply indented

27. 'Tnurnoss, with the first pair of wings streaked or banded across, the hinder margin rounded, slightly acute; the feet simple

28. Cuanissa, with the wings having a contral ring; the first pair streaked or banded across; the hinder margin 
rounded, slightly acute; the shanks of the hinder legs thickened

29. ANCERons, with the wings not angular, yellowish with dots, and a darker crescent; the first pair entire, the second pair somewhat deeply denticulated

30. Itppsrenus, with all the wings green, having indistinct pale stripes

31. ('L.on $\mathrm{A}$, with all the wings powdered, having two deep black streaks minutely notched

32. Atcrs, with the second pair of wings somewhat denticulated; the shanks of the linder legrs thickened, and often with small bundle of hair

33. Bоламд , with the second pair of wings somewhat denticulated; the shanks of the hinder legs slender and simple.

34. Larextra, ivith the first pair of wings having a tather straight streaky band in the middle; the second pair with the posterior margin waved

35. Enecrna, with the wings yellowish; the first pair banded and angular

36. Porvriasia, with the wings prettily streaked; the first pair with a wavy insolid band in the middle

37. P'uвánрталух, with the first pair of wings having

a slanting streaked band in the middle
38. Eurnat.rA, with the first pair of wings without

bands, green, with darker streaks
39. Rums, with the first pair of wings not banded, yellow, with brown waved streaks

40. MisanIPPE, with the first pair of wings not banded,

7hite, with an interrupted deep black border
41. Stroxis, with the first pair of wings not banded, pale, netted with brown

42. HLLors, with the first pair of winiss somewhat rufous, having two angular streaks; second prir with the binder margin indistinctly waved

43. Numcris, with the first pair of wings somewhat pifous, having a hatchet shaped band; the sccond pair bith the hinder margin indlistinctly waved

44. Actongia, with the fust pair of wings pale, with brownish streaks; the second pair with the hinder margin his tinctly waved 
45. Anruxss, with the first pair of wings pale, having deep black spots; the second pair with the hinder margin indistioctly waved

46. Brstoy, with the wings entire, and without angles; the body thick and hairy; the jaws very short

47. P'HIG A LIA, with the wings entire, not angular; rather broad, or very short; the body thick and hairy; the jaws wantiug

48. N $x \operatorname{ss} \wedge$, with the wings entire, not angular, narrow, or wanting; the body thick and hairy

49. Lonopron $A$, with the hody slender and scaly; the wings more or less translucent and clear; the second pair short, with the base dilated or lobed

50. Anisorteryx, with the body slender or scaly; the wings more or less translucent and clear; the second pair short, with the base simple; the antenna fringed

51. Cinmatona, with the first pair of wings blunt, having the hinder margin rounded, with an insolid band in the middle

52. Ororsвis, with the first pair of wings blunt, having brown waved streaks

53. HibenNin, with the first pair of wings blunt, having the hinder margin somewhat abrupt towards the posterior angle

54. TuEna, with the first pair of wings acute, with the hinder margin rounded

55. Pschycnemis, with the wings opaque, dull or slightly lucid: the first pair longish and narrow, with the shank of the hinder legs thickened

56. Cuesias, with the wings opaque, dull, or slightly lucid; the first pair longish and narrow; the shank of the hinder legs slender

57. Lozogramia, with the wings opaque, dull, or slightly lucid; the first pair longish, broadish, acute, with a slanting streak at the tip; the shanks of the hinder legs thickened

58. PuASIANE, with the wings opaque, dull, or slightly lucid; the first pair with two streaks, and an interjacent dusky spot; the shanks of the hinder legs slender

59. Anartis, with the first pair of wings having an insolid middle band; the forehead very prominent 
60. C'вz A, with the first pair of wings having an inPAOR solid middle band; the forehead slightly prominent

61. IIAnpalyce, with the first pair of wings rather long, acute, the hinder margin somewhat abrupt, with a solid band in the middle; the base underncath not crested

62. Srroanocorma, with the first pair of wings rather lone, acute; the hinder margin somewhat abrupt, will a solid band in the middle; the base underneath with a long voncealed crest

63. A plocen a, with the first pair of wings rather long, having an insolid band in the muddle

64. SNERANZA, with the first pair of wings rather long, with no bands, yellow or rusty

65. Juraces, with the wings erect; the first pair not banded; the legs short

66. SIONA, with the wings spotless; the first pair not banded; the legs very long

67. M $n s i \Lambda$, with the forst pair of wings pale, and liaving two black cross streaks

68. Aspriatrs, with the first pair of wings yellow, having two slanting buff-coloured streaks

69. Fuprtmera, the first pair of wings longish, blunt, the posterior margin rounded; the sceond pair short

70. Prycuoroms, with the first pair of wings streaked orross, the border waved; the second pair not stiort; the hinder legs bearded or thick

71. P'ucrorinasis, with the first pair of wings not streaked; the inarin black

72. IIYnis, witl the first pair of wings not streaked; the hind feet simple

73. Mrvon, with all the wings rounded, of one colour, 5lack or brick red
74. Creogenr, with all the wings rounded, of one culour, white or yellow

75. 1'sobos, with all the wings rounded; black, witl deper streaks or tawny bands

77. PILIONm, with all the wings rounded ; yellowish, bith purple streaks

78. Cinmus, with all the wings rounded; white, wits lusky cross streaks 
79. Xerenc, with all the wings rounded; thite, with an interrupted black border

80. 13APTA, with all the wings rounded; snow white, with very indistinct dusky streaks

81. Fidons s, with all the wings rounded, powdery, and with dusky uniting streaks; the antenna much pectinated.

82. Cidaria, with the first pair of wings, with a somewhat solid band in the middle

83. Lamicesin, with the first pair of wings having numerous waved streaks

$$
\text { PLATYPTERICID E (STEPHENS). }
$$

The body slender; the antenna of the male for the most part pectinated; two palpi short, awl-shaped, curved towards the tip; the caterpillar lizard-shaped, behind tapering, without any clinging feet.

\section{Divided into}

1. Platyitenyx

2. Datpana

3. C'ILIX

\section{PYRALIDAE (LEACH).}

'The borly always sleneler; the untenne of the male bristle-shaped, and rarely pectinated.

1. Hyrena

Divided into,

2. Polypoonn

3. Madopa

4. Clempobia

5. Agrossa

6. Pуratis

7. Agrotera

8. Sумлётитs

9. Ennychis

10. Pyrausta

11. MYDROCAMPA

12. J)APIANIA 


$$
\text { OF Motils. }
$$

13. Borvs

14. Miroaritia

15. SCOPULA .

16. Nora

17. Asopia

18. Nyapiula

\section{TORTRICINA (RENNIE).}

\section{Divided into,}

1. Tonrricid $x$, with the antenne always bristle-shaped; the wings with their outer margin arched at the base, and so nariowed as to give the insect a short broad form at the shoulders

2. Yrononeutide, with the under palpi longer than the hearl, often in form of a muzzle

3. I'innive, with the wings rarely rounded at the tip, oftener acute, convoluted and deeply fringed ; first pair long and narrow, the second pair broad and folded dusing repose.

4. Aluctrins, with the body and feet long and slender; the wings, particularly the second pair, divided lengthwise in the form of feathers; the antenne always bristle-shaped. 229

\section{TORTIRICIDA (STERHA.)}

Divided into,

1. Cinconinolis

2. Tortux

3. Lozotenia

4. Ampirsa

5. DiTULA

6. Antitursia

7. Spilonota

8. P'sеидотомiА

9. Sitecanoptycua

10. Anchyiopeita 
11. Semasta

12. Apiffia

13. Cnephasia

14. Onthotenia

15. Pecilochroma

16. Ртхснодома

17. Euchromia

18. Lorhoderus

19. Sarnothripes

20. Prenonea

21. Paramesia

22. Leptograma

23. GLypuisia

24. 1)ICtYonteRYX

25. Cinzmatorilila

26. AngrRotozA

27. ABGYROLEHA

28. Juposilia

29. Р'нun eochros

30. Lozopera

31. Xantuosetia

32. Phibalocera

33. Hypeticallia

34. ORthotzla

35. P'JOXOPTERIS

36. Carpocapsa

37. T'eras

38. Cociryus

\section{YPONOMEUTIDA: (SIIIULAS.)}

Divided into

1. DEPREsantA

2. ANACAMP3IS

3. I.OPHONotus

4. Cimuaria.

j. Jicurvaria

6. Macrocullia

7. ENicostoma

8. J)AsYcira 
9. $\Lambda$ nela

PAGR:

10. Capillaria

.195

11. Diurnea

12. Jigigaphia

- 196

.197

. 197

13. Melanolevea

14. IPONUMEUTA

- 197

- 197

15. Anerrosetia

16. Anoynomiges

17. II ERBEIA

18. Microsetia

19. (ÉcopHona

20. Pancalia

21. Ponrectatia

. 200

. 200

. 202

. 203

, 206

. 207

. 209

\section{TINEIDAE (SterneNs.)}

Divided into

1. Galeeria

2. Ityinia

3. MELIA

4. Eudorea

5. JHYcita

6. Oncocera

7. Силмвев

8. Cirlo

9. P'lutelita

10. Y Ysolorius

11. Euplocamus

12. Tinea

13. Lrpidocera

14. INCURVARIA

15. LaMpronia

16. Graciliaria

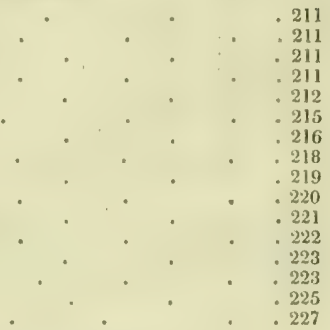

\section{ALUCITID $\mathbb{E}$ (LEACU.)}

Divided into

1. 1'тиRophones

2. Alvejta 


\section{ERRATA.}

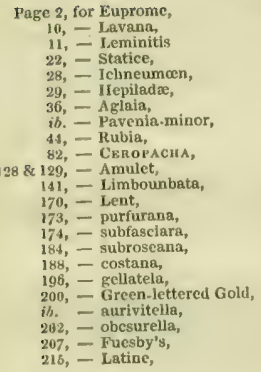

read Europome.

- Levanu.

- Limenitis.

- Statices.

- Ichneumon.

- Hepialide.

- Aglia.

- Pavonia-minor.

- itubea.

- Ceratopacha.

- Annulet.

- Limboundala.

- Kent.

- furfurana.

- subfasciana.

- rubroseana.

- costosa.

- geintella.

- Greek-lettered fould

- aurivittella.

- obscurelta.

- Fuesly's.

- Satin. 
CONSPECIUS

op

\section{BUT'TERTLIES AND MOTIIS.}





\section{CONSPECTUS OF BUTTERFLIES.}

\section{PAPILIONIDAE (LEACX).}

PAPILIO (RAY).

Palpi very blunt and short, scarcely reaching the hood (clypeses), the third joint wanting or very small; antenna with more than thirty joints, and the clubbed tips somewhat eurved ; feet (tersi) with distinct claws not forked; upper wings triangular, somewhat curved like a sickle at the outer crige; under wings: with a pointed tail, the inner margin will a scollop to receive the abdomen.

Eigs not known; caterpillar witlout hairs, with an organ in the neck in form of a $\mathrm{Y}$, which can be protruded or retracted at pleasure; chrysulis, girt with silk, angular, with two ears.

Tue Qunen (Papilio Regina, DE GEeR) appears the end of (May and beginning of August. Wings three inclies seventweliths, somewhat indented; yellow with a black margrin, and yellow crescents; the under wings with a tail, and red and blue eye spot. Caterpillar, smooth, pale green, with black, red-suotted rings, feeds on fennel and wild carrots in July and Septenher. Chrysulis yellowish green. Not common. Kent, Nortolk, Hants, Cambridge.

The searce Swablow Tan (P. Polaliriks, LiNx.) It is very doubtful whether any specimen has been found in Britain. The New Forest specimen proved to be $P$, Regine.

\section{GONEPTERYX (LEACH).}

Palpi very flat, sliort, but longer than the head, the tip joint short; anlense with less than thirty joints, short, thick, with the clubbed tip becoming gradually thicker; fect (tarsi) with the claws short and forked; upper wings somewhat three comered; tenter wings somewhat egg-wedge shaped, with a groove to reccive the abdomen.

EgR not known; caterpiller withont hairs; chrysulis, girt with silk, somewhat angular, with a beak.

Tur Primose (Gonepteryiz Ihamni, LeAcr) appears the middle of February, beginuing of June, and in nutumn. Wings two inches and a half; angular; primrose yellow in the male, greenish white in the female, each with a darker spot. 
Caterpillar, pale green, with a whitish stripe on the sides, feeds on the buckthorn and borry bearing alder (Thamnas frangule); Chrysalis greenish, suspended. Common in the south.

\section{COLIAS (TABRICIUS).}

Pulpi projecting beyond the head, very flat, the tip joint the shortest; antenua with less than thirty joints, short, rather slender, the clubbed tip blunt; feet with small, weak, forked claws; ayper wings somewhint three cormered; undtr wings roundish, with a groove to reccive the abdumen.

Fisc not known; culerpillur warty, and without hairs ; chry. satis, girt with silk, somewhat angular, with a beak.

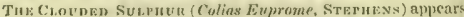
the millde of August and in September. Wings two inches to two inches one-sintis; abnve very jale sulphur yellow (ste. phens' specimen) with a black border, spotted, in the female, with ycllow; in the centre of the upper wing a black spot, and in that of the under an eye spot. Caterpillur and chrysulis un. known. Very rare, and even doubtful as a native. East cuast.

Tui searev Chounfo Yellow- (C. Pulano, Stipuks) very doubtful as a British species.

TuE Cuouden Gounk ( $C$. Chrysotheme, Strpnexs) appear in septemler. Wings one inch two-thiros to oue inch fivesixths; alrove Eoldon yellow with a black border, spotted in the femalc with yellow; the upper wings rounded. Probably a small pale variety of $C$. iddusa. Norfolk.

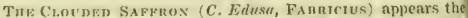
midlle of August, and early in spring. Wirss one inch twothirds to two inches one-third; above decp saffron yellow, sometimes with a rosy ploss, with a black border, spotted in the fe. male with yellow; upper ones will a black spot in the centre; the under ones rrenish undernoath, with a silvery spert; some with five or six reddish brown spots. C'aterpillar, dull green, with a white atripe om cach side, feeds on grass. C'hrystis treen, with yellow and black lines. Not common. Norfolk, Kent, De. von, Jersey.

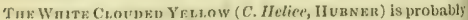
only a pale varicty of $C$, Eidusa,

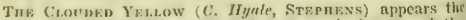
middle of Aurdst. Wings two inches to two inches one-sixtls; above pale sulphur yellow or creamy white, with a black borcler, spotted in a contirnums line, the ujper with a black spot in the contre, the under with a silvery spot; female whitisls. Coter. pillar preen and velvety, two jellow lines on the sides; feeds on papilimaceous plants in July. f hrysulis green, with y chlow lines on the sides, Rare, Kent, Norfolk.

PONTIA (PABRICIUS).

Palpi short, with three joints, the tip joint longer than the 
second: anlenna with more than thirty joints, long and slender, the clubbed tip flattish and abrupt; fert with very short forked claws; "jpw" uings somewhat three cornered, with a blunt corner at the tip: under wings not variegated beneath.

Hifk somewhat tlask shaped, with elevatcd ribs; enterpillur. somewhat spindle shaped, downy, and in some warty; chrysulis, girt with silk, angular, with a sharp beak.

TuF CABBAOE (Pontia Brassiea, STEPIENS) appears the middle of May, and the middle of August or beginning of Sejtember. Wines two inches and a half to thrce-fourths; white; first pair above with the t.p blackish, the inner edge of the black deefly indented bencath with two black spots; second pair rather long, yellowish underneath. ("aterjillar greenish, with small black warts, and a ycllow line on the back and sides; tail black. ( $/ h^{2} y$. salis pale green with black spots, and tirce yellow stripes. Fery common.

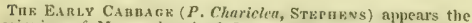
beginning of May and end of June. Wings two inches onefourth to one-half; white; first pair above clouded with somewhat asliy black, and with yellowish white fringes; the inner edge of the black on the tip not indented; inderneath with two black spots; scconi pair rather short; bencath yellowish, and much spriakled with very mimute black points. Perbaps only a variety of $f^{2}$. Brassica. Ilerts and Derbyshire.

THE TURNI $\left(l^{\prime}, R(1)\right.$ a, STEPHEN $)$ apjears the end of April or micldle of May, and berinning of July or middle of August. Ihings one inch seven-tweliths to two inches nad a half; white or yellowish white; first pair abuve with the tip pale thaky, and the base a little blackivh; beneatl, in the male with one, and in the female with two black spots; second pair rather long; unilerneath hright jellowish, sprinhled witls rery minute black points at the base. ("riterpillur frecn, with a lim-s-coloured line on the back, and yellow spots on the sides, Chrysalis greenish, with three sulphur-coloured lines. Very common in gardens.

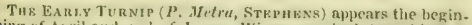
ninf of April and end of Jume. Wings one inch two thirds to cleven-twelfths; white, black at the base; first jair above with the tip sliphtly cloteded; bemeath witbout spots, or with one oni) in the male, and two faint black spots in the female; second par rather short; undermeath jellowiah, sprinkled with very minute black points. Jrobably ouly a variety of $P$. Ii aper. Herts and Surrey.

The Navsw (P. Napi, Strpuss4) appears the middle of May and begiming of $J u l y$. Wings one inch oze-third to two inclues; ahore white, heneath with dilated greenish norvures; first pair with the tip blake, ome black spot in the male and two in the female; the second pair rather long, yellowish. Cuterpillar, green, with white warts and black "yes, feels on the navew and other brasicas. Chrysulis kreen, with sjots on the hoad and back. Very common. 
Tur Garat Nayew ( $P$. Nupare, Strukna), Wings one inch five-sixths to two inches one-sixth; milk-white; first pair above with a spot, the tip and some dashes black; second pair pale, with the three first nervares dilated and greenish. Most probably only a large variety of $P$. Napi.

Tuk Con wort ( $/$ '. Sabellica, Stephens) appears the berinning of June. Wings one inch seven-twelfths-five-sixths; roundish; above whitish, with a blackish base, and on both surfaces the nervures dusky; above, the first pair with one dusky spot in the male and two in the female; bencath, first pair with the tip, and the second pair (which are rather short) ycllowish. Probably only a variety of $P$. Napi. Surrey and Middlesex.

\section{MANCIPIUM (FABRICIUS).}

Palpi short, with three joints, the tip joint shorter than the second; antenne with the clubbed tips flatish and grooved; repper wings distinctly round at the tip; under wings variegated beneath.

Tur Rock Aucust. Wiags one inch five-sixt.ls; white; first pair in the male spotless, in the fernale with a central spot, and the tip black; the seeond pair heneath yellowish green, in the male spothess, in the female with white spots; the margins of all the wings dusky. Calerpillar dull blue strilied with ycllow, and dotted with black; head Ereen, with yellow stripes and black dots: it fecds on wild wond, base rocket, cabbage, \&c. Clrysulis brown or green. Rare. Bath, Bristul, Hampstead, Cam. bridge, Dover, Canterbury.

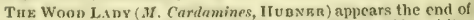
May. Wines oncinch one-third to two inches one-twelfth; white; first pair with a black central crescent on beth surfaces, and in the malc a large saffron-coloured spot towards the tip; second pair variegated underncath with yellowish green. ('aterpillur, solitary, green, with a white stripe above the lecs, feeds on lady's snock, ficld-cabhage, ke. Chrysalis green, with a slen. der white streak on the sides; on the wing-cases of the male is a safiron-coloured spot. Common in fields and lanes, and near woods.

\section{LEUCOPHASIA (STRPIRNS).}

Palpi very short, with three joints, the first large, the sccond smail, the tip one minute and globular ; nutenno with the clubbed tip flattish and abrupt; feet with distinct forked clasvs; wings opaque, and plentifully covered with seales, very narrow, wedge shaped, round at the tip; under teings with a slight groove.

Tнв Woop Werte (L. Loti, RENNik, appears the end of May and beginning of August. Wings ,one incl onethiret to one inch five sixths; white, spotless; tirst pair above dusky at the tip; second pair underneath clonded with ashy. Calpryillar, freen, with a deep yellow strije on the sides, feeds on the bird's foot trefoil and pea everlasting. Chrysalis grecnish, with a yellow streak on the sides, and white spots on 
the segments. Not common. Kent, Surrey, Essex, Devon, Forest IIill, Darenth Wood.

\section{PIERIS (SCHRANK).}

Palpi short, with three joints, the first long, the second half as long, and the fip joints half as long; unt enne, with the clubbed tips fiattish and abrupt; feet with very short forked claws and cushions; wings entire, sparingly covered with scales, and somewhat trauslucent; upper wings somewhat triangular; under wings somewlat oval, with a groove to receive the abdomen.

$E_{g F}$ not known; erterpillor somewhat spindle shaped, hairy, and sliglitly warty; chrysulis, girt with silk, angidar with a blunt beak,

TuE IJAWTHORN (Picris Crutogi, Schrank) appears in June. Wings two inches onc-third to five-sixths; of a uniform white, with black nervures. ('uterpillitr, at first gregarious and black, afterwards with a black line on the back and sides, feeds on the hawthurn and fruit trees. Chrysalis lemon-coloured or Whitish, with black streaks and spots. Not common. Coombe Wood, Surrey, New Forest.

\section{DORITIS (FaBRICIUS).}

The Crimson Rinokd ( $D$. Apollo, Stephens), Indigenous to Norway, and said to be British by mistake.

The Arine Write (D. Mnemosyne, Steriens). Indigenous to the Aljs, and said to be British by mistake.

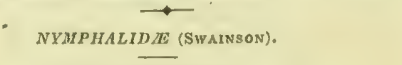

\section{A. FrITILLAfIES.}

NEMEOHIUS (STEPHENS).

Palpi very short and hairy, with three joints, the first very small, and the third alout half as long as the second; unterna with clnblyed tips, short and flattish; forr legs short and hairy; hinder leyss without spurs; feet with minute undivided claws: unper vings short and triangular; under wings somewhat round and indented.

E $E g$; enterpillar; chrysalis, not known.

THE Duke (N. Lurinz, Stratens) appears the end of May and June. Wines one incls to one inch one-third ; first pair black, spotted with tawny; second prir underneath with two bands of whitish spots. The female darker-coloured above. E'nterpillus. said to feed on grasses. Not common. Woods in Kent and Surrey, New Forest, Dorsetshire and Berkshire.

\section{MEIIT.A.A (FAвRICIUs).}

Pulpi longer than the head, very hairy, with three joints, the first slightly bent, the third in some half the length of the second, 
in others short and minute; antenno with more than thirty Jrints, the clubhed tips short, abrupt, blunt, large, aud tlattisli; fore logs small, the feet with a small cushion, in some the nails are double, in others undiviated; upper wings longish and trian. gular; under wings roundish.

kigg not known; caterpillar downy, with spines in some, and fleshy warts in others; chrysalis somewhat angular with a blunt head, suspended by the tail.

Ture Ynu,ow Crasernt (M. Athalia, Stwpunss) appears the end of May and beginning of July. Wings one inch serentwelfths to three-fourths; Ahove black tessellated with tawny second pair underneatlo with tawny spots at the hace, a band of yellow spots in the middle, and a row of yellow cresecnts at the tip; male smaller and more distinctly marked. Catryillw brown. Not common. Caen Wond, Mictdlesex; Dartmour, Devonshire, and Hartley Wood; Essex, Dover.

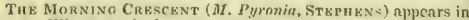
June. Wings one inch seven-twelfths; first pair abeve tawny, witl black blotches, underneath with a black band and tawny nervures: second pair black with a tawny streak, underneath with a whitish band and black spots and ncrvures. Probably only a variety of $M$. Athulia. Rare, Middlesex and Peckham, Surrey.

THE Br.Ack Crescevt (M. tessellata, StKpluks) appears the beginning of May. Wings one incli two-thirls; above tawny, tessellated with black; second pair undemeatli straw colour, with thrce yellowish bands and hlack crescents; the fringes white, intersected with black. Cuterpillur black, with a pale linc on the sides. Probably only a variety of $H$. Altulits. Very rare. Caen wood, Middlesex.

TuE Stantous ( $M$. Artemis, Leach) appents the middle of May, and rarcly nuits its natal ficld Wings one inch one-third to one inch eleven-twelfths; above tawny, waved with black, and spotted with yellowish : second pair undernenth with three buffcoloured bands, and, on both surfaces, a streak of cye-likc spots. Female larker and more distinctly marked. Cntrrjillar, black ahove, and yellowish beneath, with a row of white dots on the back and sickes, feeds on the devil's bit seabions (Scabiost succisu) ke. Remains in snciety under a silken web from Sep. tember till the middle of April. C'/rysalis grecnish white, with black spots and yellowish tubercles on the hinder yart of the body. Not common. Norfolk, Sutfolk, Middlesex, Devon.

The Granvin.x (M. Cinria, Lraca) appears the middle of June. Wings one inch three-fourths to eleven-tweliths; alove orange tawny, tessellated with black; second yair underneatl with lluree ycllowish batids, edged and spotted with black, and towartis the hinder margin, on both surfaces, a row of cye-like suots. Female darker below than the male, Caterpillav black, with a row of white spots on the sides; it feeds on various kinds of plaintain, appears in autumn, and lives in socicty beneath a silken web till April. Chrysalis brown beneatl, with tawny 
stripes. Very uncommon. Middlesex, Kent, Hampshire, Yorkshire, Lincolushire, Bedfordshire; near Dover.

I'HE Aspen (M. Maturaa, Stephens). Said to be Jritish on doubtful authority.

Th: Gommas (M. Din, Stephens). A contincatal species, said to be luritish by mistake.

THE Su.vkr Spot (M. Silene, Ltacu) appears on heaths and in woods, in May, the beginning of July, and in August. W' ings one inch two-thirds to eleven-twelftlis; tawny, spotted with black ; secont pair underneath variegated with red and yellow, with twelve silvery spots, a black cye-like spot, with a red pupil, and towards the hinder margin, a streak of black spots. Varies much. ('aterpillor black, with a clear stripe on the sides; the spines half yellow. Common in the south of England, Essex, Devon,

Tre Prinex (11. Frephosyne, J.kacn) appears in May. Wings one inch threc-fourths to cleven-twelftis ; ormge tawny, spotted with black; second pair underneath variegated with red and yellow, with nine silver spots, seven of which are placel on the hinder margin, one wedlge-shaped in the middle, and one at the base, with a yellow eye-like spot, having a black pupil. Varies much. Cinterpiller, black, with two orange-sputterl streaks on the back, feeds on violets, such as the viola luten, and riola canina. Common in wonds in the south of England. Penge Common, Essex, Devon, and near Edinburgh.

\section{ARGXNNIS (FARRICIUS).}

Palpi not much longer than the head, divergent, hairy, with three joints, the first curved, the second broad, the third nectleshaped, and very small; antemes with more than thirty founts, the clubbed tips short, abrupt, blunt, large, and flattisls; fore legss short, the claws with double nails: npper uings triangular; under wings somewhat round, and both nore or less intentcd. Females usually diarker than the males.

Egg conical, with a round point, and many clevated ribs: caterpillar witb spines; chrysalis somewhat angular, commonly with metallic spots, the head notehed, suspended by the tail.

Tнв Prixesss (A. Luthonin, Lrucit) appears in May, Angust, and Scutember. Wings one inch five-sixths to two inches onetwelfth; tawny orange, distinetly spotted with black; second pair underneath with numcrous silvery spots, and, towalds the hinder margin, a row of seven red eye-like sjots, having a sil. very pupil. Cnterpiller, brown-grey, with a whitisli tine on the back, and two brownish ones on the sides, the spines and legs pale yellow, feeds on heart's.easo and saintfoin. ('/urysulis dull brown, with a ycllow stripe on the back, sprinkled with gold and silver dots; a white streak at the ond of the wins-cases. Very scarce. Norfolk, Dattersen, Surrey, Kent, Ilertfort, Cambridgeshire.

A Bant's (A. Niobe, Stermens), Said to be British on doubtful authority. 
THE Hü BHown (A. Adipne, Leacu) appears the end of June and beginning of July. Wings two inches and a half to three-quarters ; orange tawny, spotted with black; second pair underneath jellowish red, with many silvery spots, and a streak of three or four red eye.like spots, having a silvery pupil, which vary much. Caterpillar, brownish, with a whitish stripe on the back, edfed with black dots, feeds on the dog's violet and hearts ease. Chrysalis reddish, with silver syots. South of Englaud, Suffolk, Essex, Devon, woods near lReading.

THY DARK GREkN (A. Aglaia, Lfaci) appears the beginning of July and August. Wings two inches one third to five.sixtlas; orante tawny, spotted with black; second pair underneath greenish yellow, with twenty-one silver spots. C'nlerpillar dusky, with a yellow line on the back, and a row of pight square spots on each side; it feeds on the dor's violet. ('hrysalis brownish red. Rather uncommon. Suffolk, Essex, Kent, Devon, Berks.

A. Charlottu, (SowerBy), is only a variety of A. Aglair.

тин Sinvi Streak (A. Paphia, I,kacu) appears the beginging of July. Wings two inches two-thirds to three inches; tawny, sputted with black; second pair greenish underneath, with four narrow silvery bands. Calerpillur, solitary, brownish, with a yellow line down the back, feeds on the dog's violet, raspherry, and nettie. Chrysalis greyish, with ycllow points. Iather uncommon. Sufiolk, Essex, Kent, Devon, Berks, Penge Common.

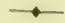

\section{B. SWIFTS.}

\section{COMMA (RENNIB).}

Palpi thickly clothed with scales and a few short hairs; $a n$ tenna with the clubbed tips abrupt; fore tegs short and very hairy; "pper wings narrow, with irregularly waved edges; tender wings with incientations and a short tail.

TIIs Comma (Commu C. album, RRNNIR) appcars the cad of June and middle of September. Wings one inch threeguarters to two inches one twelfth; above dark orange, spotted with black and brown; second pair underneath marked with a reversed and snowy white C. Caterpillor, brownish red, with the fure-part of the back yellow, and the other white, feeds on hop, willow, elm, gouscberry, currant, nettle, hazle, and loneysuckle. Chrysalis flesh-coloured, with a contraction in the middle, and spotted with fold. Rather uncommon. York and South of England, Suffulk, llerts, Pextge Common, on poppies.

\section{VANESSA (FABRICIUS).}

Palpi halry, with a fow seales intermixed, nore than twice the lemith of the head, jrojecting obliquely, the tips beaked, with three joints, the first short and curved, the second long, 
the third the length of the first, and needle shaped; antenna longish, with about thirty joints, the clubbed tips oblong and abrupt; eyes very downy; fore leys very hairy, somewhat like a tipuet; feet with long double claws, or with a nail-like projection; upper wings somewhat curved, and three cornered; under wings somewiat three cornered, with a short tail, and a groove to receive the abdomen.

lyy oval, with many elevated ribs (except in $V . P$ olychloros); catervillar with divided spines; rhrysulis somewhat angular with two ears, commonly filded with metallic spots, suspended by the tail.

TuE ELat (Vanessa Polyehloros, LeAcri) appears the middle of July. Wings two inches one-third to three inches; dark orange, inwardly covered with tawny hairs, and scales ut the base, and clouded with black beneatly; second pair with the hinder margin black, with blue crescents; all the winirs uncierneath ashcolourcd, with black bands, Cutprpillur, blackish, with a ycllow stripe on the side, fects on clm, dog-wood, and fruit trees; when young it is gregartous. Chrysulis flesh-cotourel. Not uneommon. Suffolk, Essex, Middlesex, Surrey, Kent, IIanpshire, Devon, Isle of Wight.

THE ToRToIsEsHLL. ( $V$. Urtifa, LEAcu) appears in spring, the end of Junc, and berinning of September. Wings one inch five-sixths to two inches one third ; above deep oraure, bese black, hinder margin black, with a scries of blice crescents; second pair covercd with long tawny hairs at the base. Cutcrpilter, dusky, head black, feeds on nettle; when young it is gregarious, Chrysulis greyish, spotted with gold on the neck, and sometimes entirely gold coloured. Common throughout the kingdom.

THE PEACOCK ( $V$. Io, LEACU) appears in spring and the middle of July, till late in antumn. Wings two and a half to three inches; above purplish, or redklish brown, with a large eye-like spot near the tip of the first, nad towards the marmin of the second pair ; underneath brown, marbled, banded, and spotted with blnck. Cuterpillur, gremarious, black, spotted with white, the fect rust-eoloured, feeds on the nettle. Chrysulis greeu, gold spotted. Common in the soutis of Eugland, and found also in Yorkshire and in Scotland.

THE Whuow (V. Antimpa, L.wacu) appcars in spring, the berimning of August and middle of september. Wings two inches five sixths to three inches one-sixtli; above purplish, posterior margin whitish or straw-colourch, (in foreign specimens buff or orange), with a series of violut-blue sjuts interiorly. The first pair have the upper edse marked with white, with two white spots near the tip; the scenud pair have a central white sjot. Cuterpillur, fregarious, black, with square reddish rusty spots on the back, feeds on the willow, birch, and poplar. Chrysalis black, spotted with tawny. Kare. Norfolk, Suffolk, Esisex, Worcester, Bcrks, Oxfurd, Cambridge, Middlesex, Iferts, lient, Epping forest. 


\section{AMMIRALIS (RENNIE).}

Palpi thickly clothed with seales, and a fow hairs intermixce ;

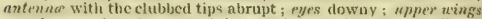
angular; under wiugs round, indented, and without any tail.

kise oval, with many elevated ridges; cuterpillor solitary, with toothed spines; chrysulis somewhat angular, commonly gilt, and suspended by the tail.

Tus Azonaman (Ammirulis Atalanta, Rennu:) appears in spring, the midclle of July and the beginning of August, until November. Wings two inclics aud a half to throe inches; deep silky black, edred with white crescents : first pair with a transverse, somewhat interrupted, orange-red band on both surfaces; sccond pair with a marginal row of black spots. Cater. pillur, solitary, frecnish, with a yellow line on the back, feeds on the nettle. ('hrysalis blackish, ashy-grey bencath, with gold spots. Common everywhere.

\section{CYNTHLA (FABRICIU8),}

I'alpi thickly clothed with scales and short hair, with three joint , the first short and curvel, the second long and llattish, the third lonfer than the first, and needle shaped; untemne with nearly forty joints; the clubbed tips very short, abrupt, and flattivi; ey/es very downy; fore legs very hairy, somewhat like a tipjet; fret with short cushious and lone claws, somewhat forked; "eings with scolloys; upper wings trianjular and some. what curvel; tonder wings somewhat oval, wodge-shaped, clothed on the upper and inner stdes with long hair, with a groove to receive the abdomen.

Fisk oval, with many elevated ridzes; rateppillar solitary, with toothert spines; chrysulis angular, commonly fllt, and suspended by the tail.

THE Panten Lapy (Cynthin Carlui, Steplatsq) appear: in sjrins, the end of July and beginning of Auenst, until october. Wings two inclies one third to two thirds; tawny brown, with a tinge of rose colour, variegated with white and black; second pair underneath marlyled, with four eyclets Varies much in brightness of colour. Cuterpillar, solitary; dusky, with interrupted yellow lines on the sides, fecds on spear-thistle, nettle, mallow, \&c. Chrysulis lirnw1, with aul. coloured lines and gold spots. Common. Edinburiph, Middle. sex, Devon, Jerkey, and in most parts of the globe.

THE HAMnstiad ( $C$. Ifrmpsterlimsis, STRPIENq), Winge two inclses; abose dark brown, with a ycllow streak at the margin; the first pair with five yellow spots, and all the wing with two black ryelets, having a white jupil. This insect has not been met with since the time of Petiver, who had it from IIampstead.

Tuv Nrrwiva ( $C$ \} Lavana, STrpuzvs). Said to be British on doubtiul authority. 


\section{APATURA (FABRICIUS).}

Palpi longer than the head, with three joints, the first short and bent, the second lone and slender, the third about the Jength of the first; and blunt; untenna long, with about thirty joints, the clubbed tips abrupt, with a poist at the cdre ; eyes without down; fore ligs very short; hind lo'ss with forked c'aws; wings with scollops; "nper wings somewhat curved and triangular; wnder uinirs rondo-triangular, with a groove to receive the abdlomen.

Kigr not known; enterpillar spindle shaped, with spines, and with horns on the head; chrysulis somewhat angular, with a beak, suspended by the tail.

Tur Eurkion (Amatura Iris, LEAen) appears the beginning of July, Wings two inches and a half to three inches and a quarter; black, or iridesecnt blus, with a common interrupted white band; second pair abosve with a single cyclet. Caterpiltrr, of a beautiful green, with recldish bristles at the tail, and greenish yellow horns; fecdv on the emmnon sallow and the oak. Chrysulis pate green. South of Eugland, Suffolk, Essex, Middlesex, Surrey, Kent, Bedford, Hereford, Berks, Wilts, and Ifants.

\section{L.FMINITIS ( $\mathrm{F} \wedge$ BRICIUS).}

Pelpi longer than the heach, clothed with sealea, and slichtly hairy, with three joints, the first small and oval, the sceond long and yightly bent, the third longer than the first, and egg shaped; antmmer lang, the clubbed tip long and slender, and ending in a point placed sideways; ryes hairy ; fore legs short, slender, with a very small claw; hind legs lonig, with claws and a short cushion; uings somewhat triargular, and with slight scollops, upper uings triangular; unle; wings rondo-triangular, with a shallow groove to recelve the abdomen.

fisg not known; caterpillar long, with blunt spines on the back, nnd tufts of hair on the sidos; chrysulis somewhat angular, with a benk, and suspended by the tail.

TII Porran (Leminitis Populi, Stronkss). Said, without proof, to be Hritish.

Tu: IIos'rysuek t.F ( $L$. ('amillu, LE.ACI) appoars the beginning of suly. Wangy two inclies to two inches one-sisth ; brownish black, indented with a central whitish band, between which and the base is an ashy creseent on the dise, and four white dots, with a double parallel series of obscure black marginal syots; underneath the central aroolet is iaserjbed with zurzag black gignatures. 'The seeond pair are very similar. C'elerpillar, green, feeds on the honeysuckle. Chrysalis green, sputted with gold, forked in front. South-eastcrn eounties of England, Sussex, Lissex, Jerks, IIants, Kent and Middlesex, Suffolk.

T'ue Proferptess, (L. Sibilla, StapheNs). Said, without, proof, to be 13ritish. 


\section{IIIPPARCHIA (FABRICIUS).}

Pulpi slightly longer than the head, more or iess lıairy, curving downward at the tip. with three joints, the first short, and the scond much longer and tlattish; entenua long, with about forty joints, the clubbed tip slender, spindle shaped and bent; ryes in some with, in nthers without, down; fore legrs shoutest, and in most cases hairy; himl legrs with sliort forked claws, and short cushims: upper wings in most cases triangular; miler wings rondo-triangular, insome with scollops, with a shallow groove to receive the abiomen.

Kige in some, with elevated ribs, in others with minute punetures, in others with net-work markings; cuterpillar somewhat spindle shaped, warty, and the tail forked; rhrysulis somewhat angular, with two ears, suspended by the tail.

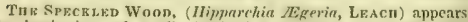
the beyinning of April, beginning of June, and beginning of August. Wings one incl and a half to two inches; brown spotted with yellow; first pair with an eyelet toward the tip on both surfaces; second pair above, with three eyelets. Varies much. ('aterpillar, green, with white lines, feeds on the couch krass. Chrysulis short, green. Throughout England, and near Edinburgh.

Tuk SpвскLev BnowN, (II, Mart, STRpizNs). Said to be British by mistake.

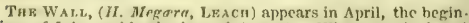
ning of July, and beginning of Augunt. Wing's one inch and a half to cleven-twelfths; tawny, with brown bauds on both surfaces; first pair with an eyclet on both sides towards the tip, with one or more adjoining it; second pair above towarls the hinder maryin, with four eyelets, the side ones being often without a pupil, and anderneath with six, the lash of which is double; female larger. Caterpillur, greenish, with dark streaks on the back and sides, fecds on grass. Chrysulis brown. Common everywhere.

TuE I3rown Wale (II, Phadra, Strmens). Said to be British without authority.

Tuk bavnen Brown (II. Aleyone, Strermas). Said by mis. take to be British.

Tuk firayine ( $I$. Semple, Leacu) appears in July. IVings two inches one-fourth to seven-twolfths; dull brown; the first pair witls two eyclets on both surfaes, and the seend pair with a single eyclet above: varies much in eolour and marktngs. Cuterpillur, green, feeds on grass. Chryssulis duaky. Lncal. South Shiedds, Scarborough, Cambridise, Suffolk, Essex, Sydenham, kent, Devon, and Salisbury Hain.

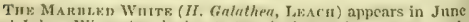
and July. Wings two inclies to twe inches and a iquarter; yellowish spotted with black; underneath the first pair with a sin. ste cyclet near the tip, and the second pair with five, one of which is double; the black lighter in the maic. Caterpillur, 
bright green, with an obscure line on the back and sides, feeds on the cat's-tail grass. Chrysalis yellowish. Throughout Eng. land: Suffolk, Essex, Devon, and Wilts.

THe Gate KEePzR ( $I$. Tilhonus, Strephens) appears the middle of Jaly. Wingrs one incli five-twelfths to five-sixtbs; above with the disc tawny-yellow; the first pair with an eyelet on both sides towards the tip; second pair with a faint cyclet towards the posterior angle, and beneatl with from three to five white points ; female larger. Catopillas, greenish, with white lines and brown head, feeds on the anmual meadow grass. Chrysulis green. Abundant near London; Yorkslie, and Northumberland,

Tnts MEAjow Brown ( $I$. Innirn, Liscil) appears in the beginning of June and July. Wings one inch and a laxlf to two inches; above nearly black; first pair with a black eyclet near the tip in the male, and in the female $(H . J u r l i n a$, LIN,$)$ a tawny. orange bloteh, in which is an cyelet; sccond pair grey underneath, with an asliy band. Cuteryillar, green, with a white streak on the sides, fceds on the mendow grass. Clinysulis yellowish, with black streaks on the breast and wing-cases. Near Loudon, north of England, and Scotland, abundant.

THis AnthN l3nowN (IJ. Ligrn, StePHENs) appears about July or August. Wings one incli five-sixths to two inches; abovo brown, with a red band; first pair with four or five eyelets on both sides; second pair above with three eyelets, and underneath with a short whitc band. Cutprpillar green, with a black stripe on the back, and several white ones; head reddish yellow. Local. Isle of Arran, Scotland.

Ture Scotcu Rinonet ( I. Blundinn, LeAcH) appears in August. Wings me inch five-sixths to two inches; abnve brown, with a reddist band towards the hinder margin, in which, on the first pair, arc four black eyc-like spots, havine white pupils ; sccond pair underneath with an ashy band: varies much in colour, the females lightest. Local. Isle of Arran, and near Durham.

Tue Bavmen Brown (H. Mnestra, Stephens). Said to be British by mistake.

Tia Mountan Ringlex (II. (assiope, Strphens) apucars in July. Wings one inch one-fourth to five-twelfths : silkez brown, with a rel band, in which are several eye-like black spots, Searce, or rather local. Ambleside, Westmoreland, and in Cumberland.

TH: Rivorkт (II. IIyperanthus, LeAcI) appears the end of June. Wings one ineh and a half to eleven-twelfths ; brown, paler bencath ; first pair above with one or more cye-like spots, and three underneath; scend pair above with two eyclets; un. derneath with two conjoining eyelets near the anterior marnin, and three behind: varies much in the size and number of the spots. Cuterpillar, whitish prey, sometimes black, with a brown stripe, fecds on and resites at the roots of the annual meadow grass, Chrysulis bright brown with obscure strenks. Abundant throughnot IBritain: Dartmoor, Devonshire, Shooter's 11ill, aud Penge Common, Kent. 
Tny MAnsu River.for (II. Polyluma, Strpness) appears in June. Wings one inch and a half to two-thirls; above kreytawny; undernoath, first pair with from two to four eyclets, and the second pair with six, bondered with white, of which three are very small: varies much. Prohably a bright varicty of $H$. Uumus. North Wales, Cumberland, aud Yorkshire.

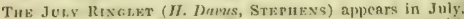
Wingh one inch nue-third to tliree-fourths; above brownish tawny: underneath, the fir yair with fwo cyelets towarts the linder markin, and one or more very faint eye-like spots, hor. clered with tawny, and the second pair with six eyclets, and a silver spot in the ceritre: varies excecdingly. Near Manchester, in Yorkshire, and Norfolk.

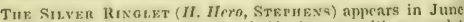
and July. Wines (one inch and a half ?) lorown, with an eyclet towards the tip on the uyper surface of the first pais; sccond pair with four or five hlind ejelets; underncath with six perfoct ones. Very race. Sussex.

Tuk 1ron Brown (H. Arramius, Sreptens) has been given as British on the doubtfil authurity of one specinen.

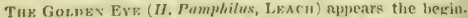
ning of June and beginnims of september. Wings one inch onesixth : tawsy with clarker marins; first pair with an cye. let on each surbice towards the tip; second pair alsove witl a very faint cyelet tuswast the posterior angle; un. Icrneath with a chort a-hy band in the midelle, in which, towats the nargin, are four minute very faint erolels: varıes much in colour. faterpitim; green, with white lines on the lack, feccls on crested dog's.tail grass. ('Trysutis green. Abmelant throughout the kingdom.

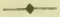 \\ LYCENII) $A \dot{E}$ (L\&ACH),}

THECLA (FАntictes).

Jelpi rather longer than the licial, clutlied with scales at the hase and a few hairs, witl three jsints, the first short and licht, the second long, the lhird sloort and pointed; antermos short, with more than forty joints, heconing gradually thicker from the base upwards, the club longert and nut flat; myes downy fras alike in both sexes: fure legs rather short; feet with larke cushions, almost concealiug the claws, which are very slowt and undivided; zuprr wimgs cutirc aud triangular; znder vings in some inderited, in others witl sliart tails.

kge not known; calropillar short, oval, and flat, in form of a wood louse (Onisfus): chrysulis, girt with silk, with the head roundish.

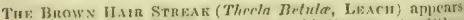
the niddle of Atertent. Wings one inch me-third toseven-twedthe; aluve dark brown; npjer wings with a black spot; undermenth ycllow, with a tawny band margince with white, frioges whites 
female with a pateh of orange hrown on the upper wings. C'aterpiller, green, with oblique yellow stripes on the sides, and two on the back ; feeds on birch, blackthorn, and plumb. ('/rysutis reddish brown, with jaler streaks. Near London, Suftulk, in Derkstire, Dorsetshire, and Devonshire.

Tun Psema Han Strnak (T'Pruni, Curtas) ajpears the end of June. Wings one juch five-twelfths; above brownish black; npper wings with an oblong spot uear the npper edpe; the uncler wings with three or more crescent-shaped scarlet sjots, with a small bluis bue at the posterior angle, underneath brownish orange; upper wings with a bluish silvery eross line sear the edge, where are several indistinct sedrlet syots, each with a blick spot and silvery culse; under winks with an interrupted silvery line acress the milalle, furming a blunt w near the abdo. men; bordor fintwia) with a black sjot betwecn each nersure, te rminated at the base of the fringe by a silvery line; the inner marsin of the horder with six or seven black spots half edired with silver; taits of the wings diverging outwards. Huntingdonshire.

The Hzack Uain Streak ( $T$. W. album, Stermens) appears in July. Wints one inch and a half to one inch seven-twelths; Abrove deep black or brown, and spotless; heseath paler, particu. larly in the tcmale; uputr wongs with a somewhat waved, white cross streak, ncarly straiglit in the male; under wings with a similar streak zig-zagered in furm of a W, and beyond it a deep orange waved marginal band, spotted on the ontside, and edired with black ou the inside; the tails of the wings parallel fougest in the female!, liack tipjed with white: the antemme black with White rims aud an orauge tip. ('uterpillur, du-ky grecu, with whitish lines on the sides, and indentations on the back, feeds on blackthorn and spirtea frutex. Chrysatis dunky brown, with a white heml. Not common. Suftolk, Surrey, Issex, Iient, Windsor.

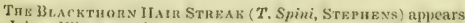
in July. Wings one inch one-third; above brown, with several reddinh sperts at the hinder tip); under wings with the tip of the tail white; bencath a di coloured, with a white streak and several tawny creacents dotted with black, and a bluish spot at the jus. terior anzle. ('ateryillur, green or redilish green, with yellow lines on the back, and the liead black, feeds on blackthora. Chrysulis brown, beneath ash-colourch. Rare. Norfolk.

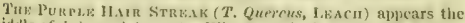
middle of July and Ausust. Nings ono inch one fumti to onehalf; ahove black ish, with a blue disc ; unleraeath ash-colonred, with a waved white streak, and it tawny twin.spot at the posterior angle. Male liorece wathout gloss; fomale all black with a purple filoss. ("atrigillor, flesily brown, with three rows of green flots, fecels on the oak. (Koysutis runt.brown, with three rows of brown dots on the back. Not uncummon throughcuit the south, and in some parts of the north of Britain, Essex, Middlesex, Keut, Devon, Huntingdonshire. 
Tife Grefa IIAIR Streak $(T, R u b i$, LeAcir) appears the end of May, beginning of June, and beginuing of Aupust. Wings one inch toone inch one-thirc, above dusky brown; some with a white spot on the upper wings; beneath green; second pair with a series of white dots, sometimes very faint; some with white spots bencatll. Catervillas, green, variegated with yellow, with a black head; it feeds on the bramble, dyer's woad, snintfoin, and broom. Chrysalis brown. Not uncommon near London; in Lisex, Dorsetshire, Devonshire, and IIampshire.

\section{LYCANA (FABRICIU\$).}

Palpi longer than the head and divergent, with three joints covered with scales, the first and second also with hair: anterna with more than thirty joints, the clubbed tip blunt and not flat; eyes not downy; legs alike in both sexes; fore legs little shorter than the hind legs; feet with large ctislions, beyond which the claws project ; "pppr wings entire, triangular, and somewhat wedge shaped; undur uings rondo-triangular, toothed at the posterior angle.

Egk not known ; caterpillar short, oval, and flat, in form of a wood louse (Oniscus); chrysalis, girt with silk, with the head roundish.

TuF Coppre (Lynana Phleas, Lever appears the beginning of $\Lambda$ jril, beginning of June, and beginning of Aurust, till November. Wings one incl to one inch five-twelfths; above, first pair of a ficry copper colour, spotted with black; sceond pair black, with a copjuer bank on the hiuder margin; some females with three or four blue spots; underneath ashy, with a tawny streak towards the hinder margin. Cateryillar, green, with a yetlow stripe on the back, fecds on the sorrel. Abundant throughout Britain.

THE GOLDEN COFPER (L. chryspis, Leach) appears in August and Sejtember. Wings one inch five-twelfths to one-half; above bright copper, with a longish central black dot; first pair beneath with ash-colourci margin, yellowish dise, and about seventeen eye-like dots; the second pair with nearly half the dise purple; bencath ash-coloured, bluish at the base, with thirty or more scattered cye-like sputs; female darker and spotted above. Very rare; near Epping.

THE LARGE Copper (L. dispur, LeAci) appears in July. Wings one inch and a half to two inches one-twelfth; above bright fiery copper colour, with an obscure band of spots near the tip, first pitir with a central crescunt-shaped black spot; underueath pale orange with ten eyclets, and the steond pair bluish, with numerons eye-like black spots; female not so bright, spotted with black above, and copper-coloured margin. ('ater' jillar somewhat hairy, vivid green, with innumerable white dots; it feeds on a kinst of dock. Chrysalis at first green, then pale ash-coloured, with a dark line on the back, and two shortish white unes on cach side, Lucal; Cambridge, Iluntingtion, Suffolk and Norfolk, Whittlesea Mere. 
Tик Swipt Coppkr (L. Iippothoё, Stgphens). Wings one inch five-twelfths toone-half; above tawny; beneathasl-coloured, with numerous eye-like black spots. Local: very rare. Whittlesea-Mere, Norfolk, Suffolk, and Kent.

Tuk Gotnen Rop ( $L$. Firgauree, LRAcir) appeats the cnd of August. Wings one inch five-twelfths to one-lalf, of a shining and bright fiery copner colour; first pair, in the male, without spots; underncath yellowish, with ten or eleven very indislinet eye-like hlack spots; sceond pair above with six black spots attached to the black hinder margin; underneath with about twelse black spots crowned with wlite, some fow orange spots near the posterior angle, which is acute.

In the female the first pair spotted above, with a markinal band of six somewhat confluent brown spots; second pair brown, with the veins, and a large square spot on the dise, of a tawny colour. Caterpiltar, dall green, with a ycllow stripe on the back, and one of yellowish freen on each side, liead and legs black, feeds on the golden-rod and docks. Chysalis brownish-yellow, witls the wing-cases rust-coloured. Rare and local. Isle of Bly and Iuntingdonshire.

\section{POLYOMMATUS (LATREILLE).}

Palpi longer than the head and nearly parallel, elothed with scales above, with three joints, the first short and curved, the second long, the third as long as the frot and without hairs; mitenne rather short, with more than thinty joints, the chubed tip abrupt and tlattish, ending in a point placed sideways; eyes in some downy, in others not; legs alike in both sexes ; fert with very short cushions, beyond which nre minte undivided claws; wings entire: upper uings triangular, and somewhat wedpe. sliaped; umler uings ovo-triangular, and scarcely, if at all, toothed at the posterior angle.

Ekg not known; caterpiltar short, oval, and fat ; chrysulis girt with silk, with the head roundish.

Tнв Azure Buve (Polyommatus Argiolus, Strernws) appears about the miditle of May and end of August. Wiugs onc inch one-sixth to one-half; above light blue, black at the tip; beneath light grey, with ohlong clissimilar black spots; female with more black at the tip of the wing. Cuterpiller, hairy, yellowish-freen, with a vivid ereen line down the back, the head and leus black. feeds on the buckthorn and holly. Chrysalis smonth, biown and green, with a black line down the back. Ncal London, Norfolk, Suffolk, Ilants, Kent, and Devonshire.

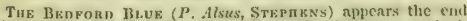
of May and beginuing of July. Wings five-sixtlis to ore inch one-twelfth; above brown, with a blue gloss; bencath ash-coloured, with a single streak of eye-like spots. Uncommon and local. South of England, Coombe Wood, Surrey, Norfolk, Suftulk. Devon,

The MazAnive BLUE ( $P$. Acis, Steprens) appeary towarts the end of May and beginning of July. Wings one inch ure- 
sixth to one-third; alonve deep hlue, with a black margin ; under. neath ash-coloured, with a central black spot surmounted with white, with a hand of eye-like dots towards the hinder margin fcmale brown above. Hare. Norfolk, Surrey, Cambridge, Dor. setshire, Mants, and Yorkshire.

TuE Anion ( $P$. Arion, Stkpnkns) appears the beginning of July. Wings one inch onc-half to two-thirds; above brown, with a blue disc, or dark blue edged with black; three smal black spots on the nidllie of the upper sviniss; female bluc, edtecd with black; seven sjuts on the upper wing, aud three on the lower (nore or less distinct); beueath ash-coloured, spotted, edged with a line of eye-like sjots. Rare. Bedford, Kent, Wilts, Bucks, and North Wales.

THk Arcon ( $P$, Allon, StepheNs). Wings one inch one. half; above bluc, without spots, and with $\mathrm{a}$ brown markin; bencath brownish ash-coloured, with a double series of cye-like dots. I'robabiy only a variety of $l^{3}$. Arion. Bucks.

Tin CHaik Hill BLue ( $P$. Corydon, Stemens) appears the midule of July. Wings one inch one-third to seven-twelfths : above of a silyery blue, with a decp black marginal band; beneath brown-ash, with numerous eyc-like spots; fringes above spotted with black; male beneath varies from a chalky white to ail colour. Female brown above, with sometimes a slight lines of blise near the base of the wimgs, edsea with yellow spots; under Ecnerally darker than the male, and the spots more dis. tinct. Frequent in the neighbourhood of Dover, Ifent, IIants, Sussex, Sufrolk, Dorset; in chalky places.

THE ClHDFN BLUK ( $P$. Adonis, STEPIIFNS) appears the end of May and midale of August. Wings one incli one-fourth to one-half; silvery blue, with a black marginal strcak; beneath ash-coloured, with numerous eye-like spots; frimge on both sides white, interrupted by brown. Male very shining light blue; fe. male hrown above, edged with a few yellow spots surrounded with black; beneath like the male. Caterpillur, Ereen, with rows of tawny spots on the back; fecds on clover. Chrysalis proen or brown. Kent, Suffolk, and Dorset.

TUE DORYLAs ( $P$ '. Dorylas, STEPHENS) appears in June. Wings one inch one-third; above bright blue; bencath pale ash colour, with a central black patch; a streak of cye-like spots towards the hinder margin, and the margin itsclf whitish. Most probably the same as 1 . Alexis. lound with the preceding. Suffolk, Itevon.

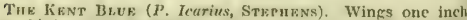
one-third; pale blue, with black margins; bencath ash-coloured, with an arched series of eye Jike dots, nnd marginal tawny spots, lemale brown, with indistinct tawny edirings, Rare. Kent.

TuF Alexis ( $\boldsymbol{P}$. Alexis, STEPIENS) appears the end of May and middle of Augunt. Wings one inch to one inch five. twelfths; above silky-blue, without spots, with a black marginal streak; underneath ashy, with numerous eyc-like spots, and a 
marginal tawny spotted band; fringes white. Males vary underneath from chalky white to ash culour; females sometimes of B light black above, sonetimes half purple, and in fine speci. mens of a beautiful purple, always edged with tawny or orangeculoured sputs, on the under surface often forming a continuous line, on which are marginal black spots. Culcrpillur, green, hairy, with a dark line on the back; feeds upon grasses, the wild liquorice, and barren strawberry. Chrysalis dark brown. Very common throughout England.

The Cupid Blee ( $P$. Eros, StrpuFns) appears in July. Wings one inch one-sixth; above pale silvery or greenish blue, without spots; beneath brownish grey, with numerous cye-like dots; the second pair having a very indistinct yellowish marginal band. keat, Surrey.

THE LEAD BLUK ( $\boldsymbol{P}$. A Agus, STEPHENS) appears the middle of July. Wings one inch one-sixth to one-third; above lilactinted bluc, with a black margin; underneath bluish. The first pair with eyc-like spots, and a faint tawny band; at the posterior margin of the second pair an orange tawny band, in which are six silvery spots. Femalc, brown above with tawny margin. ('aterpillur, green, hairy, witl white warts, and a reddish brown line, edged with white on the back and sides, and some oblique streaks of the same colour on the sides; head and legs brown; feeds on melilot, broom, and saintfoin. Clirysalis at first green, then brown. Common. Surrey, Kent, Mants, Dorset, Cambridgeshire, Suffolk, Nortolk.

The Brown Argus ( $P$. Agestis, Str.muns) appears the begin. ning of June and middle of August. Wings oue inch to one incli one-fourth; above brown on both sides, with a red spotted marginal band; benenth greyish brown, with numerous eye-like dots; fringe variegated with white and brown; the first pair with a black sjut on the disc. Males are of a lighter colour underneath than females. Near London, Norwich, ipswich, in Suffolk, Essex, Dorset.

Tue Duruar Arous ( $\boldsymbol{P}$. Salmacis, Stephxns) appars in Junc. Wings one inch one-twelfth to one inch one-sixth; dusky black, underneath diugy, with somewhat eye-like spots; first pair with a dot above, in the male black, in the female white; second pait in botli with a red band near the margin. Durham.

TuE Scotcr ARgus (P. Avtarerzes, STEPukNs) appears at the end of Juty. Wings one inch to one inch one-sixtl; above brownish black; on both sides of the tirst pair a white spot on the dise, the second pair with reddish erescents; underneath, a white margin with a row of orange spots, Male, lighter than the female. Local, near Edinburbh and bumfries, Scotland; Devon. The Durham specinens, probably $\boldsymbol{P}$. Sulmacis,

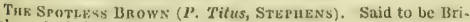
tish on doubtful authority. 


\section{HESPERIDAE (SWATNON).}

THYMELE (FABRICIUS).

I'alpi mather longer than the heat, very hairy, the thp joint blunt; antenne with more than thirty joints, longish, with the clubbed tip spindk-shaped, curved, and ending in a sharp hook. legs long, with minute forked claws and cushions filling the spaces between them; wings entire; upper uings brond, short triangular, and roundish posteriorly; under wings broad, rondo. triangular, and slightly toothed.

EKR not known; culerpillar without hairs or spines; chrysali with the head notched.

TuE Grizzle (Thymele Alueolus, Steprikns) appcars about the end of May. Wings from five-sixths to one incli one-sixth. above black, with numerous white square spots on both surfaces. sometimes confluent; underneath greenish-grey. Fringe white, barred with black. Herts, Essex, Kent, Wits, Yorkshire, Cam bridgeshire.

Tue Mallow (Th. Malne, Stepaens). Said to be British by the mistake of confounding it with Th. Tuges.

Tnk DrNay Skimper (Th. Tuges, Stepukns) Rppears about the end of May and middle of July. Wings one inch one-twelfti to onc-third; above brown, indistinctly clouded with ashy-grey with indistinct seattered white dots on both surfaces, and a mar. ginal series of white dots; beveath mrey: the colours mor obscure in the male. Caterpillar, bright green, with a brown head and a yellow stripe, dotted with black down the back and sides, feeds on ficld eryngo, and bird's-foot trefoil. Chrysalie, the fore part dull green, the latter part reddish. Unconmon Cumberlaud, Yorkshire, Norfolk, Suffulk, Middlesex, Kent, Sur. rey, Devon.

The Georgian Grizzla ( Th, Oileus, Stephens). Said to be British on doubtful authority.

\section{PAMPIILA, (FABricius).}

Palpi slinrt, flat, in some very thickly clothod with scalcs and short stift bristles, in others thickly clothed with scales alone: antenne rather long, the clubbed tip spindle-shaped, in most cases ending in a hook; head rather large; upper wings longish, and almost triangular; unler wings with a very minute tail at the posterior angle. sharp.

Egf not known; caterpillar downy; chrysalis with the head

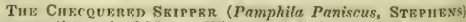
appears the end of May. Wings one inch one-sixth to onefourth; above blackish brown, spotted with tawny; beneath yellowish brown; second pair with twelve whitish spots. Femalt jarger than the male. Caterpillar, dark brown on the back, with the sides paler with two yellow stripes, head black, and si 
orange-coloured ring round the neck; feeds on the great plantain. Northamptonshire, Bedfordshire, Oxfordshire, Devonshirc.

THl WoOb SRIPPER (P. Sylvius, Stepilens). Said to be British on doubtful authority.

Tue Great Streak Sipper ( $P$. Linca, Steruens) rppeats the end of July. Wings one inch to one inch one-fourth; above tawny, without spots in the femalc, with veins and margius black; underneath, the second pair are tawny ash colour. The male lias an oblique black line in the centre of the first pair. Caterpillur, solitary, green, with a dark line on the back and sides, Chrysatis yellowish green, Abundant: near London, Kent, Carabridgeshire.

The Clouded Serpper ( $P$. Sylunus, Strifhens) appears the end of May, and in July. Wings one inch one-sixth to fivetwolfths; alove brown, with pale square spots; underneath yeliowish wlite. Male has an oblique brown line on the upper wings, like the $P$. Linea, which is wanting in the female. Kent, Yorkshire, Devon, Cambridgeshire, and near Newcastle.

The Peari. Skiprer ( $P$. Comma, Stephens) appears the middle of August. Wings one inch one-sixth to five-twelfths; tawny or grey, with pale or whitisla square spots on both surfaces; the male has an oblique black patch in the centre of the first palr. C'aterpillur, dull green, with a row of black spots on the hack and sides, head black, with a white collar, feeds on the Coronilla varia. Sussex, Middlesex, Wilts.

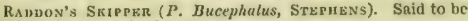
British without authority.

Tuk Bonnened Surpper ( $\boldsymbol{P}$. Vitellits, StepanNs). Said to be British on doubtful authority. 


\section{CONSPECTUS OF MOTHS.}

\section{SPHINGINA (RENNIE).}

\section{ZYG}

INO (LFACI).

Tup GrenN Forrster (Ino Stutices, Leacii) appears the middle of Junc. Wings one inch to one inch one-third; first pair alove blue-green; underneath brown; the second pnir on both sides are brown; antenno pectinated and club-shapet. Cater. jillur, dusky, with two lines of white crescents on the back; fecels on sorrel. Chrysulis dusky. Not common. Kent, Surrey, Hert fordshire, Essex, Middlesex, Yorkshire, Cambridgeshire, North. umberland.

Tuk Bhegenten Forectkr (I, Globulatia, Stephexs). Sup. posed by Stephens to be only a variety of 1 . Statice.

\section{ANTIROCERA (SCOPOLT).}

Tite Mrzhot Burner (Anthrorera Meliloti, Stepiteng) appears the end of June. Wings one inch one fourth to one third; first pair greenish-blue, or greenish-black, transparent, with five red spots; second pair red, with an indistinct freenish margin. Caterpillar, green, head and fore legs black, with a white stripe en the back, and a line of black spots on the sides, feeds on dover. ('hrysalis yellowish whitc, with the back and wing-cases dusky. Rare. Surrey.

TuF Trafoil Burnet (A.Trifoli, Stzpirens) appears the end of May or beginning of June. Wings eleven-twelfths, or one inch one-sixth to one-fourth; first pair preenish blue, with five red spots, two of which are in the middle, and frequently confluent; underneath of uniform colour; second pair red, with a broad grcenish bluc margin. Caterpillar dull yellow, with rows of black spots; it feerls on trefoil, Chryzsrtis black. Abundant. Jevonshire, llants, Cambridgeshire, Nortlsumberland, Middlesex. Probably only a variety of $A$. Loth

Tak Five Spot Burnet (A, Loti, Stephens) apears in June. Wings one inch one-third to one-half; first pair decp greenish 
blue, with five red spots; underneath of uniform colour; seconul pair red, with the border broad, wavy, and dark blue, Easily distingaished from the preceding by the waved margin of the hinder wings. Caterpillur pale green, with a row of black spots on the back and sides; undezneath the spots on the sides the females have a bright ycllow streak; feeds on trefoil. Chrysalis ycllowish, having the wing-cases black. Not common. Kent.

The Tripuk Spot Burnet (A. Scabiosa, Sterinns) appcars the end of May and beginning of June. Wings eleven-twelths to one inch one-sixth to one-fourth. First pair green, with three longish red streaks; becond pair red, with a deep blue margin. Doubtful as a native, or probably only a variety of $\mathrm{A}$. Loti.

THE Liguonice BurNet (A.Mippocrppidis, Strpness) appears the middle and end of Junc. Wings one inch one-twelfth to seven-twelfths; first pair bluish black, with six red spots; second pair red, with a grcenish blue margin, waved internally :- the ablomen without spots. Citerjillar, freenish, on each side a yellowish stripe and a row of black spots; feeds on the wild liquorice. Chrysalis dingy brown, with a freenish abdomen spotted with black. Not common. Surrey, Kent.

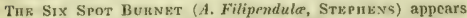
the end of Jume or berinning of July. Wings one inch onehalf to seven twelfths; first pair nzure blue, with six blond. Ied spots; second jair deep red, with an judistinct dark blue margin; abdomen spotless black. Caterpiltar primrose ycllow, with three rows of black spots on the back, and a row of smaller ones on cach side; head hlack; feeds on pliuntain, clover, clandelion, mouse-ear, hawksecd, quake grass, \&c. Chrysalis yellow. Common. North of England, Devonshire, South Wales, near London.

The Sulpiun-Wort Buenet (A. Peucedani, Stepikns). A loubtrul species.

\section{SPIINGIDHE (LЕАCH).}

\section{SMERINTHUS (LATREILLB).}

ThE Even IIAwK (Smerinthus ocethatus, I, ATRRILLE) appears the end of May. Wings of the male two inches three-fotirtis to three inches; female three inehes and one-haif to two-thirds ; first pair angulated, rosy-asli coloured, with a slanting, clouded, central band, aud posterior margin irregularly brown; second pair rosy at the base, the tips much paler, with a large blue eyclet near the prosterior angle. Cuterpiltar, very rough, of a fine green, with slasting white stripes on the sides; the fore leg's rose-red; fects on willows, poplars, and fruit-trees. Chrysalis blackish brown, Subterranean. Abundant. Dssex, near London, Devon, Yorkshire, Cambridgeshire, Surrey, Westmoreland.

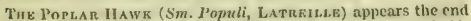
of June. Wiogs of the male three inches to three inclies one-half; 
female three inches one-half to four inches one-third, irregulasly indented, krey clonded with reddish ; first pair with a white cres. cent on the dise; second pair with a large nust-coloured bloteh at the base. The thorax and abdomen ashy and spotless. Cuter. pillire, solitary, rourh, green, with a yellow line on each side, and with slanting white stripes; feeds on poplars. Chrysalis dingy brown. Common. Surrey, Devonshire, Westmorcland, Northumberland, Cambridgeslire, South of England.

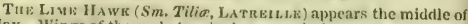
May. Wings of the male two inches one-sixtl te twouthirds; female two inches one-third to three inches; somewhat three-lobed, frey, clouded with rosy-grey, sometimes iron-red, with an inter. rupted central hand, the posterior fringe olive-brown; second pair grey, with an indistinct brow ish band, terminating in the postcrinr angle. Caterpillar, solitary, rough, fore-part slender, green with slanting red or yellow stripes, fecels on the lime, elm, flder, bireh, and oak. Chrysalis dusky brown. Abundant. Hertfordslure, Surrey, Essex, Yorkslite, Devonshire.

ACIIERONTIA (OCHSENHEIMKR).

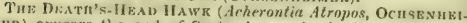
B1sn) appears the end of Septembor or beginning of October. Wingsot the male four inches one-thircl to two-thirds; female four inches five-sixths to five inches one-twelth; first pair brown, clouded with yellowish, with a white spot on the disc; second pair freyish, with two deep brown bands. Abdomen yellowish brown, with beits, and an interrupted black line down the back. Caterpillur, solitary, posteriorly yellow, spotted with black, with slanting lines on the sides, of which the first half are blue, the remainder green; seldom ventures ont during the day.time, feels on potatoe, jasmin, thorn-apple, spindle-tree, hemp, elder, woody nikhtshack, \&c. Chrysalis brown, with five black points on each side. Not common. Ayrshire, Berwickshirc, Surrey, and Wilts.

SPHINX.

Tut: Tonaceo Haw (Sphin, Carolina, Lannzes). Indigenous to North America, but doubtful as Englisl.

THE Yer.ow-spot UnנconN HAws (Sph. quinque Afaculatus, HAworTH). Imported like the preceding, from America?

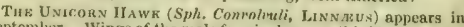
September. Wings of the male four inches one-third to one-half; female four inche's one-half to two-thirels; first pair ash.coloured, clouded with black and brown, with a few rigzag black lines; the second pair with four irregular black bands. IIead, ash. coloured; thorax asliy-brows, with indistinet clark lines; abdomen decp ash, with about five red spots, surmounted with white and black. Cuterpillur, green, spotted with blnck or brown, with dingy jellow slanting stripes down the sides, horn dingy, feeds on the greater and lesser bindwecel. Chrysalis bright brown. Rather rare. Caithness, York, South Wales, Cumberland, Cambridge, Middlesex, Surrey, Kent, Cornwall. 
Drent's Irawg (Sph. Drecei, Donovas). Supposed to have been imported from America,

TuE PrivieT Haw x (Sph. Ligustri, Linnaws) appears the end of Juneand heginning of July. Wings of the male three inches one half to four inches one quarter, female four inches one-sixth to fivesixths; first pair ash-colourch, pale at the base, with a broad dingy band drawn lensthwise from the inver margin to the tip; second pair rosy, with three black hands; aldiomen purj,le, with black rings, interrupted on the back with ash colour, with a line town the brek. Caterpillew, dingy reddish-green; foeds on the privet, common and Persian lilac, elder, ash, \&c. Chrysulis bright reddish-brown, with the tiv slightly forked. Rather uncommon. Ilertfordshire, Surrey, Kent, Cambridgeshire, Yorkshire, Cumberland,

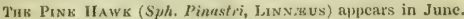
Wings three inches one-sixtli to five-twolfhs; nsh colour; thorax with three black lines lengthwise : first pair with three uncqual black lines in the centre, and a whitish stripe along the sides of the corselet and posterior margin; sides of the corsclet red, with hlack bands, with a line on the back and three on the belly, all black. Catripillar, light hrown, with a dark ycllow stripe on the sides, head dusky; neek varied with dusky and brown; segments with eight slanting black lines; the loorn black, divided at the tip; feeds on various species of the pine. Chrysilis greybrown. Rare. Scotland, near Edinburgh ; Sussex;

Thк Plembian Hawg (Sph, plebeio, Рanucius). Said to be British on very doubtful authority.

The Varjkonten Hawk (Sph, pocila, Stephens). Said to be British on very doubtful authority.

DELLEPHILA (OCHSRNHEIMKR).

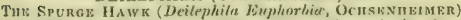
appearsthe beginning of Jume. Wings of the maletwoinches fivesixthy, female three inches one-twelfth; first pair grey, with a brond posterior streak and two spots on the upper edge greenish; the second pair red, with a band and the outer marsin black; the antenne white; the head white, with n greenish tonp. Cesterpiller, in its first state quite black, afterwards spotted with red, and lastly with a black skin having whitish points; feeds on various kinds of spurge. Chrysalis pale yellowish brown, with longish wing-cases. Rare. Devoushire, Warwickshire.

Tuk Mandek IIawk (D. Gatlii, Laaru) apjear's the begin. ning of June. Wings two inches five-sixths to three inches; the first pair greenish, with a whitish streak lengtlwwise; the second pair black, with a pale band clouded with red ; the antennae brown, with white tips; the back dotted with white. Cinterpillar, olivegreen, with a yellowish line on the back; feeds on the yellow Lady's bed.straw, wild madder, anul dyer's madder. ('hrysulis dark brown. Rare. Near London, Kent, Cornwall, Devonshire.

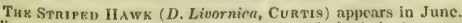
Wings three inches one-fourth; the first pair indistinct green, with a whitish streak drawn from the base to the tip, obliquely 
intersected by six white reins resembling lines; the second pair black, with a broad streak drawn lengthwise from the base to the hinder margin, clouded with red; all the margins, except the upper, are dingy white. Cuturpiltar, yellowish at the tail, spotted with black, with the head, a line on the back, and spiracles rose. coloured; feeds on the yellow laty's bed-straw, and on the vine. Chrysalis rosy brown. Rare. Norfolk, near London, Devonshire.

THx CARrot Hawk (D. Datens, STEPHKNS). Indigenous to North America, and doubtful as British; or probably a variety of D. Livornica.

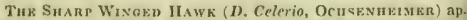
pears in July. Wings of the male two inches five-sixths, female three inches one twelith; the first pair grcyish, with white longitudinal lines lengtlswise, and a bright silvery band; the second paif brown, with the base and six spots on the hinder markin rose. coloured. Caterpillar, brown, with two whitish lines on the sides, and two eyelets on each sicle of the neck; feeds on the vine. Chrystalis lingy brown. Rare. Cambridgeshire, Norfolk, Oxforctshire, Warwickshire, Lancasbire.

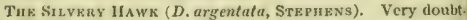
ful as British.

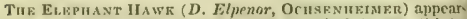
the end of Junc, Wings two inches one-sixth to two thirds. the first pair olive-coloured, with three slanting reddish purple streaks, The second pair anteriorly hlack, posteriorly rosy (aterpillar, dingy brown, with two blue eyclets on each side ol the neck; freds on the yollow ladiy's bed-straw, hairy willow herb, vine, \&e. Clhrysalis anteriorly dull grey, posteriorly brown, with the spiracles obscure. Not uncommon; near Loudon, Hertfordshire, Surrey, Devonshire, Shropshire, Cambridgeshire. Yorkshire, Northumberland.

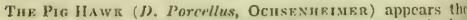
berinning of June. Wings one inch five-sixths, to two inche one-twelith; the first pair varied with yellow and purple; second pair brown at the base, with a ycllow band and purjole inargin underneatlı the abdomen dotted with white. Caterpillor brown, with three bluish eyelets on both sides round the neck. Chry sulis blackish. Rather scares. Surrey, Shropshire, Warwick. shire, Yorkshire, Dorset, Wiltshire, IIunts, Cambridgeshire, neat London.

\section{SESSIID) TE (STEPUENS). \\ MACROGLOSSA (OCHSENHKIMER).}

THRIIUMMINe 13IRd It A WK (Alurroglossa stellatarum, Ocrsis. MRImFr) appears the end of April, June, and August. Wing one inch three-fourths to two inches, first pair dingy brown. with two wated black streaks, with a spot or circle betweel them; second pair rust colour, with the hinder marpin dings. tinged with rusty brown, the fringe whitish; the sides of thi 
abdomen varicd with black and white. Caterpillar, speckled with white, with a yellowish line on the sidle; feeds on various kindls of bed-straw and dyer's woad. ('hrysalis pale brown. Not uncommon. Kent, Ilertfordshire, Surrey, Cambridgeshire, Yorkshire, Northumberland, Hants.

\section{SESIA (FARRTCIUS).}

The Drove Bre Hawr (Sesin Fuctiformis, Strmens) appears the end of May and beginning of June. Wings one inch two thirds to three fourths; olive brown; the abdomen tawny, with a broall black band; the margin of the wings light brown. C'rtterpillar fecrly on the devil's bit scabious. Chrysalis brown. Very rare. Near London, Berkshire, Cambridgeshire, Jiants.

THE BKE FLY UAwK (S. Bombyliformis, STKPaY, N4) appears the end of May. Wings one inch two thirels to five sixtlis; freen-ish yellow, with a band and broad margin blackish purple: the abdomen greenish yellow. Cateryillar, green, with a yellow stripe on the sicles snd back, horn straight and reddish brown; feeds on the honeysuckle nnd bed-straw. Chrysalis dusky brown ; with yellowish streaks. Not common. Surrey, Kent, Essex, Hants, Yorkshire.

TH: Cimanx IIAwk (S. Cimbiciformis, Sterhens) indigenous to North America, and doubtful as British.

\section{AEGERIII) $/ E$ (STEPHENS). \\ TROCHILIUM (ScOPOLI).}

THE BRE HAWR (Trorhiliem A piformis, STEPINDE) appears the end of June. Wings one inch seven-twelfths to five-sixths; brownish, with the mareins and nervures brown : heat yellow: thorax black, with four ycllow spots; abtomen ycllow, with the second and fourth rings hlack. ('ateryillor, whitish, head brown, feeds on the trunk and boughs of the poplar nnd aspen. Chrysalis brown, the segments fringed. Not common. Evaex, Surrey.

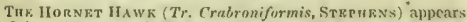
in July. Wings one inch one-half to two-thirds; iron red, head black; thorax brown, with n dull yellow spot on each sile, with a narrow yellow collar; aldomen yollow, and with two black rings. Caterpillar, whitish, with a brown spot on several of the rings near the legs; fecds under the bark of the sallow. C'krysntis brown, the rings fringed. Not very common. Kent, Nor. thumberland.

\section{MGERIA (FABRICIUS).}

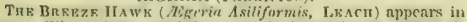
June. Winges cleven-tweltths to one inch ouc-fourth; firt pair tawny ; second pair brown; abdomen brown, with three yellow belts, Rare. Near London, Kent.

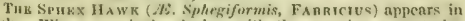
July. Wings one inch; dusky, with the margins, a posterior 
band, and the tips, bluish black; the antenna bluish black, with a broad whitish band; abdomen above with a whitish spot, and two underneath. Caterpillur is sait by Oeblmann to feed on the birch. Very rare. Southgate wouds, north of London, and in the Isle of Wight.

THE ICHNEUMEN HAWK (JE. Iohmomoniformis, CURTAs) appears in June. Wings five-sixths to eleven-twelfths of an inch; transparent, and brownish black : markin and tip dark yellowish brown, with a reddish streak, black on the inner edge; abdomen black, with several equidintant yellow hands. liather scarce. Cornwall, Devonshire, Yorkshire, Islc of Wight, Sussex.

THE Runy Fly HAwk ( $\mathscr{H}$. Chrusidiformis, Curtrs). Wings one inch five-sixths; bluish black, tirst jair with the margins and tips saffiron yellow, and a central black sjot; abdomen bluish black, with two whitish rings. Very rare.

THE GAIL FI.Y HAw K ( $/ E$. Cynipiformis, J.KACH) appears the end of May and heginning of June. Wings one inch threefourths to eleven twelfths, blue black; first pair with the tip, a slantinf line on the dise, nervures, ast markins, brown; the outer cate of the line on the disc saffron yellow; alxilomen with five yellow riners; fect tawny, with hlack Joints. Not scarce. Coombe and Darenth woods, Chcltenham, and in Clapham Park wood.

Tun Currant Hawk ( $\mathscr{E}$. Timeliformis, Lencu) appears the middle of June. Wirnes one inch two-thirds to five-sixths, blue black; first pair with the margin, tip, and line on the disc as in the preceling; tip with streaks of gold yellow; abdomen with a black tust at the tail, and the alternate segments yellow. Cater. villar, solitary, rather hairy, wbitish, lead and begs brownish, with an obscure line ou the back; feeds upon the pith of the currant trce. Common. York, and near Neweastle, London,

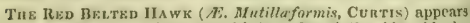
in June. Wings one incli two-thirkls to five-sixths, blue black; first pair above with the nervures, margins, tip, and broad slanting band on the dise, bluish black, bencath golden yellow; second pair with the upper edge gulden ycllow, a spot and margins bluish black; abdomen shining, with a ycllow ring. Not abuudant. Near London, licrtford, Ripley, and Dublin.

TUE GNAT HAWE ( $E$. Culiciformis, StrpHWNs) appears in Jume. Wings five-sixths to one inch, bluish black; the palph tawny underneath. Culerpillar, dingy white, with the head rusty brown; fecds under the bark of fruit trees. Chrysnlis brown, the segments fringed. Scarce. Near London and Dublin.

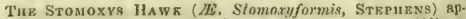
penrs the beginning of July. II ings cleven and one half lines, like the preceding. Corselet with two orange tawny lines; the abdomen with a belt, and spots on the sides, tawny orange. Rare. Gravesend. Curtis says this is the female of $L$ : MU. tillaformis. 
THF ANT JAWK (A. Formiciformis, LNAca) appears the middle of sune. Wings eiglit to ten and a half lines, blueblack; first pair with the upper edge and a slanting line on the lisk, orange brown, with the tip flame yellow; second pair wath the nervures and margins brown; the abdomen black, with a broad flame-red belt, the tuft at the tail black, with a white streak on each side. Not common. Ireland, Lincolnshire, and near Limehouse.

Tuk Day ILy Hawk ( IE. Ephemeraformis). Antenna pectinated; the tip hairy; wings bhe-black, with ycllowish brown nervures; abdomen without belts. Very rare. Yorkshire.

\section{BOMBYCINA (RENIE).}

\section{IEPILADIE (STEPHENS).}

HEPMLUS (FABRICIUS).

TuE GoLden SwIFT (Itpialus Hetus, Fabicivs) appears the middle of June. Wings one isch to one inch one-third; first pair very bright ycllow in the male, ashy-brown in the female, with three slanting bands of fold yellow spots; the sceond pair lingy. Not rare. Cumberland, Devonshirc, Dear london,

THb VARIABLE SWIPT ( $1 \pi$. Lupulimus, Fabricius) rppers the end of May. Wings, male one inch to one inch one-fourth, female one inch one-fourth to seven-twelfths; first pair ycllow in the male, dusky-ash in the female, with a central streak, and two bauls white; the extermal one interrupted with a row of spots; the sccond pair ash-coloured. Caterpillar dusky, with black spots, Not uncommon in gressy meadows.

The Guost Swift (II, Ifumuli, FABRicius) appors the middle of June. Wings, male one inch two-thirds to two inclies onc-twelfth, female one inch five-sixths to three inches; suowy white in the male; the female has the first pair yellow, with streaks or spoti, sccond pair dusky. Cuterpillar, cream-coloured, with a brown licad; feeds on the roots of the hop and burdock. Chrysalis dark brown. Common in churchyards, whence its name. Scotland, Ircland, near London.

Tin BEAvtirul. Swikt (H. Velledi, Hawortu) appears the midale of June. Wings of the male one inch four-sixths to five-sixths, female two inches one-sixth to one half; raried with yellow, livid, and white, with a row of white or silvery spots on the hinder markin, and brown spots on the upper edere. Catrpillar is said to feed on the fern. Local. Darenth, York, Cheshire, Derby'shire, Wilts, Kent, Scotland.

Tue Livin Swipt (II. carmus, Fabricius). Wings, of the male one inch two thirds to five-sixths, female two inclics onefourth to two-thirds, livid; first pair, clouded with white and yellow, with a serics of pale spots on the inner edge; nearly spottess in the female. North of England, Warwick. J'erhaps a varicty of $I f$. Velleda. 


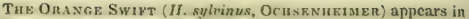
August and september. Wings of the male one inch to one inch one-third, femele one inch oue-hali to five-sixths; male above yellowish-brown, with a wayy slanting white streak at the base, and another at the hinder marsiu; a small indistinct brown spot on the dise, bound internally with white near the centre. The female has 8 large patch of dingy white at the basc, and a row of tharkish spots on the upper edge. Second pair brown, with a ycllowish maryin. Not raue. Lee, Birchwood, near flertford, stoke Newington, and York.

\section{ZEUZERA (LATRIELLF)}

THE WoOD LFopaitD (Zeuzeta As'sculi, LATrEILle) appears in Juiy. Wings of the male two inches one-sixternth, female two inches two-thirds to tive-sixths; some what naked, and translucent; snowy-white, with the veius and upper edge yellowish; thickly scattered over with numerous bluish-black spots. Second pair more faintly, aul not so numeromaly spotted, except on the margins; spotless at the inter angle. Thorax white, with twelve black spots. Calerpillat, deep yellow, dotted with black, head and tail black; fecds on the wood of the pear and apple, walnut, eln, lirue, horse-chestnut, ash, becch, birch, oak, Kc. C'/rysarlis pale brown. Rather rare. Norfolk, Warwick, Wilts, Essex, Cambridge, and Surrey.

\section{Cossus (Panrictus).}

Tuk Gotи Motr (Cossus ligniperdu, Fabricius) appens the cnd of June and heginning of July. Wings of the male two inches five-tenths to three inches ouc-fourth, fomale three inches onehalf to three-fourtis, clouded with frey ank brown, with athmerous Alanting black streaks: corsulet whitish, with a posterior black band. ('alerpiller, dull yellow, with a brown-rerl back, yellowish underneath, head black, with cight brown spiracles on each bide; fects upon onk, willow, asjen, and poplar. I'upa brown, with indented fringes to the segments. Not common. Near London, Kingston, Bottisham, and Deputiord.

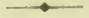 \\ NOTODONTID $\mathscr{L}$ (इTEPHENS).}

PYGARA (OCHSENHEIMER).

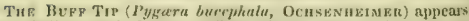
the middle or end of June. Wings of the male two inches onesixth to one-half, female two inchey two-thirds to eleven-twelfths. lirst pair silvery ash, with a double anterior strenk, rust-co. loured black; also a double posterior streak, interrupted and more wavy black, rust-coloured, with a large yellow spot at the tip. Caterpillar, hairy, dusky yellow, above spotted with black, head black, with a yellow spot, legs outwardly black, inwardly yellow; feeds on the lime, oak, willow, elder, elm, and chestnut. Japa subterrancous, brown spotted with yellow. Common. 


\section{CI.OSTERA.}

'TuE Rust Per (Clnstera anastomosis (Strparns). Said to be British on very doubtful euthority.

Tuk Reclusk (Clostera reclusa, Stкrinss) appears the end of May. Wings of the male one inch to one inch one-sixteentl, female one inch to one inch one-fourth; brown; first pair ashy-brown, with four anastomosing white streaks, a reddish. brown pateh near the tip, and a white marginal spot. Second pair dark brown. Caterpillar, brown, with a broad line on the lack, ycllowish-white, the sides with a chain-like series of yel. low circles; feeds on the aspen in September. Pupa brown. Kare. Darenth and Birch woots, Epping, Cambridge, and Dublin.

TuE Ascmoret ( $C$, anachoreta, Stepitiss). Wings of the male one inch one-fourth, female one inch onc-third; grey, with four whitish streaks, the fourth wavy, and jassing over the rusty-brown spot at the tip; towards the posterior angle two black spots, the inner one largest. Caterpillur, brown, hairy, with a flesli-coloured streak on the back, with two warts, and spots on the sides yellow; fecds on willows and poplars. I'upa brown. Very rare.

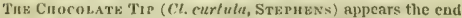
of April or beginnimg of May, Wings of the male one inch one. third to five-twoltths, femalc one inch one-third to une-hadf; greyish-ash ; first pair with four nenrly straight whitish streaks; the tip reddish-brown, with an indistinet row of five dingy spots. C'atevillar, solitary, hairy, ash-coloured, with four rows of rustred spots, feeds upon poplars and willows in Stptember. Not common. Near London, Wanstead, and Coleshill.

\section{EPISLMA (OCHSENHEIMER)。}

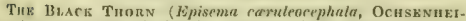
Mar) appears the midlile of August and in September. Wines of the male one inch ono-fourth to five-fwelftls, femal, one inch one-third to one-half; ashy-grey, ratler oblonge, with confluent whitish points between two brownish streaks, and an ashy marginal band. Female rather darker. Cnterpillur, smovth, bluish, with yellow lines and black spots; feeds on the white thorn, black thorm, and fruit trees. I'repu brown, within a strong silken web. Common. Near London.

\section{CERURA (SCHRANR).}

THe Tivin Point (Cerura bieuspis, SrkPHens) appears in July. Wings of the male one inch one-sixth to five-twelfths, female one inch one-thire to one-half; snowy-white; first pair, the base and hinder margin, spotted with black, with a slanting asis-coloured waved band. Second pair with a central spot, and nervures dingy yelow. Caterpillar, saffron-yellow, with three redish-brown spots on the sides, mrecnish underncath, feeds on willow. Rare. Darentil Wood, and near Dublin. 
TuE ENTIRE ( $C$. integra, STEPrass), Wings one inch seventwelfths; whitisll; first pair spotted with black at the base and posterior margin, followed by a slanting ashy band, margined on botlt sides with black: corselet asb-grey, with three slantlng black bands. Caterpilinr? green, with a violet purple spot, and a series of red spots on tho back, margined with yellowish; feeds on birch. Rare. Coombe Wood?

Tав KıтT:N ( $C$. furcula, Scurank) appears in July. Wings of the male one inch one-sixth to one-third, female one inch one-fourth to one-half; grcy; first pair, with black spots at the base and himder margin, with a central ashy band, terminated by beveral dingy streaks; a row of diugy spots on the margin, and whitish fringe: corselet anteriorly stey, with a black slanting band; posteriorly brown. Cuteryilim, kreen, smonth, solitary, witl a forked tril ; feeds on various species of willow, nspen, and poplar. Pupu brown, in a laard case. Rare. Near London, at Coombe and Darenth woods, Ilertford, Ripley, Epping Forest, York, and Coleshill.

Tru Bow (C. arcuata, STnPmens). Wings one inch fivetwelfths; dingy ash; first pair with black spots like the precel. ing, with a narrow slanting ashy band, margined with black, with a posterior waved streak of bowlike lines: corselet ante. riorly asliy-grey. Caterpillur, pale green, with a bluish back, sides with a white furrov, spotted with red; feeds upon willows. Rare. Coombe Wood.

Tú Brond Bar (C. latifascia, Cuatrs). Wings one inch seven-twelfths to two-thirds; whitish; like the preceding, with a broad achy band, varied with orange, and bordered with black corselet bluish-black, with two faint orange bands, anteriurly ashy-grey. Rare. Near London, Linton, and North Devon.

THE KitTunet ( $C$. fuscinula, StepuENs) appears in July Wings of the male one inch two-thirds, female one inch two. thirds to five-twelfths; whitish; first pair with the base and posterior margin spotted with black, with an ashy slanting bani, waved outwardly; collar grey. Caterpiller, emerald green, with brown head and blue back, feeds on birch and oak. Liare. Near Loudon, Darenth Wood, and İpping Forest.

Trk Clevr (C', bifida, LisAcH). Wings of the male one inch two-thirds; femate une inch five-sixths to eleven-twelfths; whitish ; first pair with the base and posterior margin spotted with black, and an ashy-grey slanting band bordered with blach. The second pair with an orange border : corselet erey, streaked with black and orange. Rarc. Near London, Darenth Wood, and nearlimehonse.

Tuz Puse (C, Vinula, Scuranz) appcars the end of May and beginning of Aigust. Wings of the male two inches onehalf to three quarters, female three inches onc-twelfth to onethird; white ashy-grey in the fenale, first pair with the upper edge spotted with black; nervures yellow; two convergent and -lanting rows of black spots near the base, followed by a brown wavell strcak; towards the middte a black ereseent, pointing out. 
wards; hetween which and the tip are two very acutcly waved browni-h slanting streaks; second pair with $\mathrm{a}$ dingy erescent spot on the disc, and one or two spots on the hinder margin, towards the posterior angle. Cnterpillar, sulitary, green, with a brownisl back; foeds on the poplar, willow, and sallow. Prupa brown, enclosed in a liard case. Not common in many parts of England. York, Cambridge, and near London.

THu Ermine Puss ( $C$. erminea, Stepiness). Wings of the mate, two inches one-quarter to one-haif, female three inches, white; first pair with several black spots at the basc, followed by fluree or four waved streaks, towards the middle a creseent on the disc, behind which are three strongly indented dinfy slanting; waved stieaks; second pair with a creseent on the dite, and row of black dots on the markin. ('ntergrillar, reddish-brown, sprinkled with white on the back, and with lines on the sides; feeds on the poplar, willow, and aypen. I'upa pale brown. Rare. Birchwood, and near London? but somewhat doubtful as a native.

\section{STAUROPUS (GERMAR).}

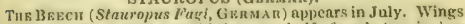
of the male two inches one-third to one-half; female two inches one-half to two-thirds; ashy-brown; first pair above the base with a linear yellowish wavy streak, and beyond the centre nnother very much waved, and indented; towards the hiuder margin is a waved row of black spots. Caterpillar, brown; the six fore legs lougish; the tail turned down with two horns; teeds on the beech, oak, lime, alder, and bloe. Puja brown, enclosed in a case, Rare. IIants, Essex, Norfolk, and Kent.

\section{NOTODONTA (OCHSENHEIMER).}

TIB DROMEDAKY (Notadonta diomedarius, STEPIENS) appcars the beginning of June and in August. Wings of the male one inch one-third to two-thirds; fomale one juch two-thirds to cleven-twclfths; reddish-brown; furst pair, with a ycllowish bloteh at the base, and two whitish indented streaks; second nair with an indistinct whitish band. Cuterpillar, solitary, smooth, green, with four protuberances on the back, and a tail hent downwards; feeds on alder, becch, hazel, and puplar. Rare. Combe aud Darenth Woods, Norwood, and in Cheshire.

TuE DARK PRoMUNeNT ( $N$, perfusea, StzrHENs) apyears in sune. Wings of the male one inch oue-half to two-thirds, femalc one inch two-thirils to five-sixtlıs, brown, with dusky clouds, a dingy anterior band, and a slanting indented streak towards the tip. Caterpillar feeds upou the oak. I'upu subteriancuus. Very rare in England; near Dublin.

Tur Peunu (N.ziczrc, Ocisenuriatin) appears in May, June, and July. Winus of the male one inch two-thirds to three-fourths, female one inch five-sixths to eleven-twelfths, yale brown; first yair with a square white patch in the middle of the upper edge, an eye-like spot, purplish, and intersected with black dashes, 
with a marginal black streak, fringe brown, dotted with white, second pair ashy. grey, with a black marginal line, fringe whitish, dark brown towards the posterior angle. Caterpillor, ashy-grey, with a pale stripe on the sides, and a reddish tail, with two bumps on the back; feeds on the poplar and willow. j'upu brown, cn. closed in a case. Not common. York, Norfolk, Kent, Surrey, and near Dublin.

\section{LEIOCAMPA (STEPHENS).}

TIE SWALrow (Leiocampe dirteu, SrEPIins) appears the beginning of Junc and August. Wings of the male two inches, female two inches one-fourth to one-third; first pair greyish white, margins brown, with a central whitish spot; sccond pair white, with a dingy patch at the posterior angle. Cuterpillur, reddishbrown, with a streak on the back; fecds on poplar, willow, and birch. P'upa subterrancous, brown. Not common. Coombe and Darenth woods, near Dover, Epjing and York.

Tru Litrle Swallow (L. dictaoides, Stepursns) appears the cnd of June. Wings of the male twoinchea, female two inches onesixth to one-third; furst pair greyish white, with a central white spot, and white triangular blotch at the hinder angle; seconi pair dull white, with a dingy patch at the postcrior angle. Cuter. piller, pale green, with a yellow stripe on the sides, and a line on the posterior protuberance; feeds on the poplar, willow, and birch. Not common. Kent, and Surrey.

\section{LOPHOPTERYX (STEPRENS).}

The Coxcomb (Lophoplery.x comelina, STErifexs) appears the end of April and begimning of August. Hings of the male one inch one half to two-thirds, female one inch two-thirds to five-sixths, brown or dingy; first pair indented, with a, very slender waved black streak at the base, a second towards the middle, and a third rather minute towards the hinder margin on the upper edge, beyond this four spots, and an indistinct pale streak; second pair whitish yellow, with the nervures and margin diugy. Cinterpillar, smooth, green, with pale lines, spiracles and protuberances at the tail purplish; feeds on oak, birch, willow, poplar, alder, beech, lime, de. Common. Near London, Durbam, and Cheshire.

The MAPLE ( $L$. cueulla, Strphens) appears in June. Wings of the male one inch five-twelfths to one half, female onc inch one. half to five-sixths; first pair pale yellow, with dark markings, the upper edge with two or three streaks in the centre, with in ashy white marginal patch; sccond pair greyish, with a rusty. brown blotch at the posterior angle. Caterpiluar, slightly hairy, pale bluish green; fecds on maple. Rare. Darenth wood, and near Erith.

Tue Cananrere ( $L$. carmelita, Sternevs) appears in March. Wings one inch seven-tweliths, brownish; the first pair whitish at the interior margin, and two white spots on the mpper edge; second pair with an indistinct whitish band, and bluish brown patch at the posterior angle. Caterpillar, Ereen, with a yellowish line on the back, and a reddisin one on the sides; feeds on birch.
Rare. Darenth wood. 


\section{PTEROSTOMA (Gernan).}

THE PAle Proninent (Pterostoma P'ulpina, Curtis) appears the beginning of June and end of August. Wings of the male one inch one-half to five sixtlis, female one inch five-sixths to two inches one-sixth; first pair greyish white, with black streaks and nervures, behind the middle an indistinct double row of black spots, and a similar one on the hinder margin, the spots being placed between the nervures, fringe pale yellow with dusky and brown. Caterpiller, smooth, green, solitary, with a yellow stripe on the sides; feeds on willow, proplar, and lime. Pupa redaish brown. Rather uncommon. IIerts, Essex, Kent, and Surrey.

\section{PTILOPHORA (STEPHENS).}

The Plumifenous (P'ilophora variegata, Stepnens) appears the end of October. Wings of the male one inch one-third to onehalf, femate one inch one half to two thirds, rusty ycllow; first pair with a ycllowish bow-like strcak behind the centre, nervures dinfy, margin and fringe rust brown. Caterpillar, yale green, with bluish line on the back, and three white ones on the sides; feeds on maple, birch, and sallow. Pupa red.brown. Rather uncommos. Darenth wood.

\section{CHAONIA (STEPRENS),}

Tile Lunar Manbled (Chuomia Roboris, Stepnens) appears in June. Wings of the male one inch one-third to seven-twelfths, female one inch two-thirds, ash-coloured, with two wavy white streaks, and a central broad white band, with a brown crescent. Caterpillar, green or brown, with two ycllow lines on the back, and a paler one on cach side; feeds in September on the oak. Scarce. Middlesex, Kent, Surrey and Norfolk.

The Dodonean (Ch. dodonen, SzupHens) appears in June. Wings of the male onc inch one-third to one.half, tcmale one iuch one-half to two-thirds, greyish ash ; first pair varjegated with brownish at the base, a broad band in the centre, with two wavy streaks, white; a triangular dingy blotch on the nuper edge, fringe white and brown. Caterpillar, freen, with a bright orange yellow stripe on the sides; fecds on the oak. Not common. Isent fand Surrey.

The OAzEN (Ch. querna, Stephens). Said to be British on doubtful authority.

\section{PETASIA (StEPIENB).}

The Sprawrer (Petusir Cossimea, Stephens) appears in October. Wings of the male one inch one-half to three-fourths, female one incli two-thirds to five-sixths, grey; first pair with a black line at the base and another on the inner margin, with smaller senttered black streaks, and a pale indistinct and almost imperceptible interrujted streak towards the hinder markin ; second pair with dingy spots and nervures; a marginal line dotted with black. Caterpillar, bright freen, with a pale line on the back and two yellow lines on the sides; feeds on lime, sallow, 
oak, beech, privet, Rc. Pupa brown. Rare. Herts, Warwick, Kent, Surrey, and IIants.

\section{PERIDEA (STEPUENS).}

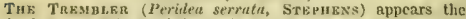
end of June. Wings of the male two inches one-sixth to one fourth, female two inches three-fourths to seven-twelfths, grey; first pair two short and indistinct black wavy streaks at tlie base, the hinder part of the wing with an indistinct brownish crescent, over which is a whitish line, followed by an indistinct waved streak, then two small lines towards the tip, and a row of dull red spots towards the hinder marzin, on which is a row of dingy crescents, fringe spotless brown; second pair, with a brown marginal line. Caterpillar, solitasy, smooth, green, with three protuberances on the back, and with slanting rud and yellow stripes on the sides; feeds on the oak. Rare. Kent, Surrey.

\section{ENDROMIS (OCHSENHEIMER).}

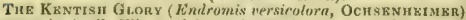
appears in April. Wings of the male two inches one-third to onehalf, female two inches five-sixths to three inches one-sixth, grey; first pair with two dingy black streaks, the first before the midelle bent outwardty and edger inwardly with wlite, the second behind the midklle colged externally with white, between them a dark crescent pointing ontwards, three slanting triangular united spoty at the tip, nervures bulging and white at the anterior angle; second pair with an indistinet eentral streak, and a dingy blotch on the upper edge. C'atmpillitr, green, dotted with brown, with slanting yellow strcaks; feeds on birch, alder, hazcl, beech, and lime. Pupa brown. Uncommon. Norfolk, Sussex, Kent, and Devonshire.

\section{BOMBVCID}

AGLAIA (OCMSENMEIMER).

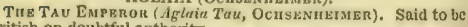
British on doubtful authority.

\section{SATUIRNIA (SCHRANK).}

Tue Eupreor Moti (Salurwia Panenia-minor, Schrank) appears the middle of May and beginning of August. Wings of the male two inches one-laalf to five-sixths, fenale two inches one-half to three inches one-half, grey; first pair with three black streaks on the sides, with a large half-closca eyclet, the tip purplish, with one or two black or red spots; second jair with a half closed eyelet, a grey posterior band, and hinder margin purplish. Caterpillar, at tirst ercgarious, freen, with a black band lengthwise, afterwards with three black ringlets and yellow warts ; feeds on blackthorn, alder, oak, bramble, ruse, elder, \&e. Pupa brown and very blunt. Not uncommon. York, Lincoln, Norfolk, Salop, Kent, and Surrey. 


\section{LASIOCAMPA (SCHRANK).}

TuF Fox (Lnsiucumpu Rubi, Sснвакк), appears the end of May and beginning of June. Wings of the male two inches onethird to one-hadf, female two inches one-half to two-thirds, reddish, without spots; first pair with two slanting whitish streaks in the centre; second pair with a whitish fringe; the fenale pale ashy brown. Caterpillar, hairy, black beneath, brown alrove, with black rings, when young with naic yellow rings; feculs on the bramble. P'vpa dusky, cnciosed in a case, with three ycllow rings. Not uncommon. York, Derby, Essex, Kent, and Surrey.

Tuk Grass Egoer (L. Trifolii, Scmrank) appears in July and Angust. Wings of the male two inches one-sixth to onethird, female two inches one-third to onc-balf; rusty grey; first pair with a whitish spot on the dise; second pair spotiess. Ca. terpillar, solitary, hairy, pale brown, incisures sfotted with blue, collar red; fects on the red clover and plantain. Pupa yellow. ish brown, Rare. New joreat, Kent.

THF Minic Eegert (L. Medienginis, Currs) appears in August. Wings of the male two inclies one-sixth to two-thirds, female two inches one-third to seven-twelftis, pale yellow: first pair with \& white spot and two whitish streaks; second pair with an indistinct whitish streak in the centrc. C'uterpillar, pale sellow, with blackish-blue incisures, and slanting white streaks on the sides; feeds on various kinds of medick. Pupu, brownish, with a greenish abdomen, in a case. Rarc. New Forest, near 13 ristol,

ThE OAв Eocen (L. Quercus, ScunANк) appears in August. Wings of the male two inches one-half to five-sixtlis, female tliree inches onc-twelfth to one-fourth; deep brown in the male, much paler in the fomale, with a broad yellow band, arched interiorly; first pair with a central white spot and yellow jatch at the base. Caterpillar, pnle yellow, with black rings, and slanting white streaks on the sides; feeds on the ash, birch, sloc, willow, oak, horn-beam, white thorn, and broom. Cocoun dusky. Rare. Near Dublin, near London, New Forest, Devonshire.

Tue Broom Enokn (L. Roboris, Senfank) appears the end of Jnly. Wings of the male two inches one-half to five-sixths, fernale two inches five-sixths to three inches one-third; of the nale brown, of the female yellowish grey; first pair with the yellow band less arched, and the central white sjot more round than in the preceding; second pair with a yellow fringe. C'at terpillur, ycllow, with black rings, a row of white sjots on the back, and slanting white and ycllow streaks on the side. Cucnon yellow. Not uncommon. Near London, Cambridge, Essex, Kent, Surrey, and Sussex.

Trz Copse Eggzn (L. Dumeti, Scunanx) Sald to be British on doubtful authority.

TRICHIURA (STEPHENS).

TrE IIAwTHORN (Trivitura Cralagi, StEPHENS) appears in September, Wings of tlic male one inch one-twelfh to one. 
fourth, female one inch one-sixth to five-twclfths; first pair ashy-grcy, with two curved streaks and a central spot dingy; second pair brownish; the female is darker than the male, and has the sccond pair of wings without spots. Caterpillar, hairy, black with white bands, and four rusty warts; fceds on white thorn, sloe, and willow. Pupa dusky brown. Rather scarce. Essex, Kent, Surrey.

\section{PCECILOCAMPA (STKPHENS).}

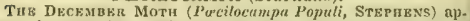
pears in Deccmber. Wings of the male one inch one-fourth to five-twelfths, female one inch one-sixth to two-thirds; chestnut brown; first pair with a pale and very incurved streak near the base, and not reaching to the inner margin, and a second waved behind the middle, the fringe frey and brown; the abdomen tawny brown; thorax black, anteriorly light grey. Caterpillar ashy-grey, darker on the back, with four reddish spots on each ring ; fecds on oak, aspen, birch, poplar, lime, rose-tree, white thorn, and fruit trees. $P^{\prime} u p a$ in a silken case. Not common, York, Essex, Herts, Kent, and Surrey.

\section{ERIOGASTER (GERMAR).}

Tuk Suall Enour (Erioguster Lamestris, Gramar) appears in February and March. Wings of the male one inch one-sixth to one-third, female one inch one-half to five-sixths; pale red; first pair with a large sput at the base, a spot on the disc, and an indistinctly indented streak towards the hinder margin, all white; sceond pair pale ash coloured in the male, frrcy in the female. Caterpillat, at first social, hairy, black, with three white spots on each ring, between two red spots; feeds upon sloe, birch, lime, willow, fruit trees, white thorn, \&c. I'upa brown. Rather scarce. Essex, Kent, Iferts, and Cambridge.

\section{CNETHOCAMPA (STEPHENS).}

The Procession (Cuethocumpa Processionea, Strpmens). Said to be British on doubtful autlority.

Tue Ping Procession (Cn, pityocrmpa, Strphens) apjycars in summer. Wings one inch two-thirds; first pair grey with three dasky waved streaks; second pair pale, with a dusky blotch at the hinder angle. Caterpillar, blackish, with a whitish liae on the sicies, with ycllow hairs on the back, and white on the sides; feeds on various kinds of pine and fir. I'upa brown. Very rare, Devoushire.

\section{CLISIOCAMPA (CURTIS).}

THF Gkounn LACKEY (Clisiocampe castrensis, Cuntrs) appears on the sea const in August. Wings of the male one inch one-sixth to one-third, female one inch one-lialf to tliree-fourths; first pair pale straw-colour, with two red strcaks, and clouted with red; frimge pale yellow, spotted with red. Citerpiltur, bluisin, with red and black streaks on the back, and red lines on the silies; feeds on various plants, sca-wormwood, birch, plan- 
tain, carrot, \&c. Pupa dark-coloured. Rare. Essex, Kent, and Devonshire.

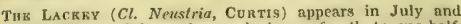
August. Wings of the male one inch one-fourth to one-half, female one inch onc-half to five-sixtls; grey, with a darker central band, and pale terminal streak on both sides. Caterpillar, gregarious, yellow, with three red lines on the sides, and a white one on the back; feeds on oak, hazel, sloe, and fruit trees. Pupa browa. Very abundant in the south.

\section{EUTRICHA (STRPHENS).}

Tue Pine Kappet (Eutricin P'ini, Stephens) appears in July. Wings of the male two inches seven-twelfths to five-sixtha, female three inches one-half to two thirds; greyish ; first pair, with a large triangular white spot before the middle, then an indistinct pale ash-coloured band; beyond the middle a rustybrown band, margined on each side with grey; second pair decper grey and spotless. Calerpillar, varicgated witl white, frey, and brown, with bluish rings and red spots on the sides; feeds on various species of pine. Pupu brown. Rare. Norfolk, and Surrey.

\section{ODONESTIS (GERMAR).}

THE Drinker Moth (Odonestis potatoria, Grrarar) appears in July, Wings of the male two inches one-third to one-half, female two inches two-thirds to three inches; grey, sprinkled with yellow, with two dusky-brown streaks, and a spot and erescent white. $E_{F g}$ large, flat, and bluish white. Caterpillar, dusky-brown, sides spotted with white; feeds on different species of grass, and lives through the winter. P'upa brown. Very common in lanes and hedge roads.

\section{GASTROPACIMA, (OCHSENMKIMER).}

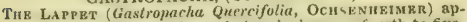
pears in May. Wings of the male two inches one-fourth to fivesixths, female three inches one-sixth to one-third; dingy red, indented; tirst pair with three slanting wayy strcaks, and a minute central dingy spot; secont pair spotless. Caterpillar, lingy brown, with blue bands; fceds on white thorn, willow rose, \&c. Pupa brown, with red bands. Rather scarce. Herts, Essex, Surrey, and Lincoln.

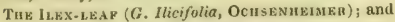

The Poplar-leap (G. Populifolia, Ocuslinielaer). Said to be British on doubtful authority.

\section{ARCTIIDAE (LEACH).}

HYPOGYMNA (IIURNKR).

TuE Gipser (Hypogyma Dispur, IIUDNKa) appears in $\mathrm{Au}$. gust. Wings of the nale one inch one-half to two inches one- 
twelfth, female nne inch two-thirds to three inches onc-twelfth the male clouded with grey and brown; the female whitish with black streaks. Caterpillar, llingy black, witl white lines, anteriorly blue, aud posteriorly red; feeds on the elm, oak, lime fruit trees, \&e. Puph brown, Very local. Surrey, Hunting. donshire, and Whittlesca-Mere.

\section{PSILURA (STEPHENS).}

Tue BuAcr Arcues (Psilurn Monerha, STrpurss) appears in July. Wings of the male one inch one-fourth to three-fourthe, feniale one inch three-fourths to two inches five twelfths; first pair white, with black spots at the base, three or four waved streaks behind the middle, and a marginal row of black spots; second pair dingy, with a black and white fringc. Cuterpillur, Ashy-lorown, with red tufts on the back, and a black heart-shaped spot on the second sefment; feeds on the oak, bramble, \&c. Jupu black. Very local. New lorest, Kent, and Surrey.

\section{DASYCHIRA (STEPHENS).}

THE BLACK TUSSORK (Dasychira fascrlina, STEPHENS) appears in July. Wings of the male one inch two-thirds to five-sixths, female one inch two-thirds to two inches one-sixth, ashy-brown; first pair sprinkled with black, with two dark brown streaks, and two slanting dingy spots near the hinder margin; second pair with an indistinct darker markinal band. C'oterpiliar, with tufts of hair, tipped with red, and white fur tufts on the back, with a brown tuft on the hearl and at the tail; feets on various plants, irefoil, dandelion, hop, bramble, oak, \&e. I'spe hairy brown, with a rale line on the back. Not common. Bedfordshirc, Kent, and Surrey.

Tне Yer. Low Tussock (D. pudibunde, Sткрпвхs) appears in June. Wings of the male one inch two-thirds to cleven twelfths, fomalc one inch five-sixths to two inches one-sixth, ashy-white: first pair with threc transverse dusky waved stregks, and a marginal row of dingy spots; second pair with a central dingy crescent. Caterpillur, hairy, yellow, with a large red tuft on the tail, and four white ones on the back; fceds on various trees in Septeraber. Pupa enclosed in a case, anteriorly black, pos. teriorly brown, spotted with yellow. Not scarce. Essex, Kent, and Hampshire.

COLOCASIA (OCHSLNHEIMER).

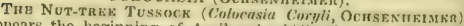
appears the beginning of April and midtle of July. Wings of the male one inch one-twelfth to one-half, female one inch onefourth to five-twelfths; first pair anteriorly brown, with a black ring and several small blotches; posteriorly ash colource, with it dingy indistinct waved streak. C'aterpiller, red, with two tufts of hair on the back, one on the tail and two on the neek; feeds on hazel and birch. P'upu encloserl in a case; anteriorly black, posteriorly hrown, Not common. Kent, Surrey, and ncar Dublin. 
ORGYIA. (OCHSENHRIMER).

TIE VApoverk (Orgyia antiqua, Ochsenhermen) appears from July to Octoher. Wings, none in the female, one inch two-bisths to one-half in the mole, rust-brown; first pair clousled with brown, with a very white crescent near the pos. terior angle; sccond pair palcr and spotless. Ciaterpiller, dusky spotted with red, with four white tutts on the back; feeds on white and black thorn, and various other trees. P'upu dingy and yellow. Common near London.

The Oranez Tussock (O. Gonostigma, OCusnnuerier) appears from June till the end of August. Wings, none in the iemale, one inch one-fourth to seven-twelfths in the male, brown; first pair with two opposite white spots, one in the posterior ancle, and the other at the thicker margin. Caterpillar, gregarions, with eight white tufts on the back, with two black gnes on the neck and one on the tail; feeds on a varicty of plants. Pupa yollow, losteriorly yellow. Scarce. Oxfordshire, Kent, and Surrey.

\section{LAELIA (STEPHENS).}

Tre Wuttreesea Eruine (Lalia Canosi, Stepuess) appears in July. Wings of the male one inch seven-twelfths to three. fourths, female one inch one-half to three-fourths, pale ycllow. ish-brown; first pair, the hinder margin with a row of indistinct dingy spots; female white, with the legs and palpi yellow. Crilerpillar, dingy, spotter with yellow, with four ycliow turts on the back, two dark ones on the heart, and one on the tail; feeds on burr-reed. Puju deep black, enclosed in a spindle-shaped cocoon. Local. Whittlesea-Mere.

\section{LEUCOMA (STEPHENS).}

TUE BLACK V. (Letu'bmu Vuu-nigru, STEPHENs) appenrs in August. Wings of the male one inch three-fourths, female one inch five-sixths, snow-white, with the nervares slightly yellowish, and a small black $\mathrm{V}$. in the centre of the first pair. Cinteryillar, with cight tufts on the back, of which the two first and last are white; feeds on the line. Pupu grecnish blue, with a black spot on tlie corselet. Karc. Kent.

TuE SATIN (L. Salicis, STEPHeNs) nppears in July. Wings of the malc one inch one-half to five-sixtlis, female one inch fivesixths to two inches, of a rich glessy white; the anterma with black plumelets, nud the legs with black rings. ('nterpillar, hiniry, blackish, spotted with red, with a row of white spots on the back: feeds on willows and poplars. Pupa hairy, clusky, enclosed in a cocuon. Very' common. Middlesex, Kent, and Surrey.

\section{PORTIESIA (STERHENS).}

Tuz Goun TAu. (Povthesia (Wysurrhou, Strpuexs) appears the end of July and begioning of August. Wings of the male one inch one-fourth to seven-twelftis, female one inch seventwelfths to five sixths, snow-white, with a dark spot at the posterior angle of the tirst pair; the plumelets of the antenure dusky yellow. Catcryiller, gregarious, hairy, blackish, with two red 
lines on the back, and white tufts on the sides: feeds on white and black thorn, clm, oak, fruit trees, ke. Pupr dingy, enclosed in a case. Abundant. Yorksiure, Essex, Middlesex, Kent, and Surrey.

The Brown TAil ( $P$. Aurifiun, Strphens) appears in August. Wings of the male one inch one-third to one-half, female one inch one-half to two thirds, above pure white; first pair beneath with a dusky cloud on the upper edye in the male; the plumelets of the antennae and tuft at the tail yellowish-brown. Cuterpillar similar to the preceding. Abundant. Near London, York, Newcastle-upon-Tyne, Kent, and Surrey.

\section{IfYPERCAMPA (IIUBNBR).}

Tue Scarlet Tiner (Iypercumpa"Dominula, Strphens) ap. pears in Junc. Wings two inches to two inches one-sixth; first pair black, having a glossy greenish tinge, with several yellowish white spots; second pair cinnabar red, and spotted with black. Caterpillav, hairy, black, with three yellow streaks and white spots: feerls on willow, ash, lound's-tongue, nettle, Rc. I'upq brown, in a lonse web on the ground. Not common. Near London, Xork, Cambridge, Oxford, Devonshire, and Ilampshire.

\section{EUTHEMONIA (STgRHRNS).}

Tuk Crounen Bupp (Finthemonia Russutu, STrpnens) appears in June. Wings of the male one inch one-hin to three-fourths, female one inch orse-third to five-sixths; buff orange, with the margins and a centual crescent, blood red. The fenaic smaller than the male, with the nervures and the crescent reddish. Caterpillar, dingy, with ycllow spots on the sides; feeds on grasses, \&e. Jup reddish-brown; in $\mathrm{R}$ well on the fround. Not very common. Darenth Wood and the New Forest; York, Cambridge, and Surrey.

\section{ARCTLA (STRPHENG).}

Tuk Grast Tigar (Arctiu Coju, ScHnank) appears towards the end of July. Wings of the male two inches two-thirds to cleven-twelfths, female two inches three-fourths to three inches: reddish-brown, with white waved streaks; second pair red, with nbout six round bluish-black spots; abilomen red, with a row of black spots. Caterjillur, solitary, black, hairy, with tliree clevated bluish warts on the sides of the serments: fects on lettuce, chickweed, and various other plants. $\ell^{\prime} u p n$ black or brown, encloset in a case. Common. Scotland and England.

Tak Sacil Matron (A. Matronula, Scmisank), said to be British on doubtful authority.

Tuz Crian-Pot Tiger (A, Villict, Scurank) appears the middle or cud of June. Wings of the male two inches onetwelfth to onc-third, female two inches one-stxth to one-half; first pair very black, marked with eight yellowish. white spots; second pair yellow, spotted with black. Cuterpillar, dingy, hairy, spotted with red; head and legs red; feeds on chickweed, and 
various plants. Pupa black, enclosed in a case. Rather scarce. About London, Hertfordshire, Sufiolk, Cambridge, Kent, and Surrey.

Thi IIene, the Purple, and the Counthen (A. Mebe, $A$. Purpuren, and A. Aulica, ScrikiNk). Said to be British on doubtful authority.

\section{NEMEOPHLLA (STKMIENS).}

THE Wood Trava (Nemeophilu Plantaginis, StrpurNs) apjpears the midclle or end of June. Wings of the male one inch one half to two-thirds, female one inch seven-twelfths to five. sixths; first pair black, irregularly strcaked with yellow; sccond pair red or ycllow, with irregular long black streaks and spots. Cateryiltm, black, with the six micklle segments yellow: feeds on plantatn. Pupn dark. Not common. Yorkshire, Westmoreland, Kent, and Surrey.

\section{PIIRAGMATOBIA (STEPMENS).}

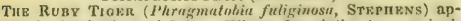
pears the beginning of July. Wings five-sixtils to one inch one-half; first pair of a reddish-trown, with two black spots in the centre; second pair red, with a row of black spots towards the hinder margin; nbolomen above red, with a row of black spots. Caterpillur, rust red, with the head and fore-legs black: feeds on plantain, dock, nettle, \&c. Not common. Dublin, Durham, Yorkshire, Ilertfordshirc, Kent, and Surrey.

\section{SPILOSOMA (STRPHBN3).}

THE Gneat Erank (Syilusema Menthrasti, Streruens) appears in May. Wings of the male one inch one-half to threefourths, female one inch one-half to eleven-tweliths, whitish, spotted with black, and having several black lines towaris the posterior margin; antennae black; the alsdomen aloove yellow, with five rows of black spots; the fore-legs yellow. ('aterpilla)" hairy, brown, with a red streak on the sides. Pupu subterrancous, reddish, in a loose cocoon. Not scarce. Near London, York, Neweastle-upon-Tyne, Epping, and Cambridgeshire.

TH: Dinoy Wure (Sp, Urtiro, Strpuens). Wings one inch seven-twelfths, whitisl ; first pair with a minute bleck dot on the tise; second jair with three dusky spots; the antennes white. Caterpillar, similar to the preceding. Rare. Epping liorest, and Yorkshire.

Tus Water Eraniza (Sp. Pupyrntir, Stipuens) appears the mitdle of June. Wings one inch one-half to two-thirds, white; first pair with three or four black spots on the disc, and a streak of black spots (about ten in number) towards the tip; sceond pair generally spotless; the corselet and tip of the abdomen snow white. Cialerpillar, deep brown: feeds on water-mint, white ladies bed-straw, \&c. I'uja dusky. Rather rare. Near London. 
TIE Spotren Bupf (Sp, lubrispedn, Strphens) appears in Junc. Wings of the malc one inch one-half to tiree-fourths, female one inch two-thirds to five-sixths, bufi colour ; furst pair with a slanting interrupted streak of black spots behind thic centre; second pair generally without spots; ablomen with five rows of black dots, Caterpillur, yellowish, with a whitish line ni the sides; feers on various herbaccous plants. I'upu subter. raneous, enclosed in a case. Common. Durham, York, Cam. bridge, Middlesex, and Devonshire.

THE RAYED BeFp (Sp, rudintu, STEPnENs). The first pair of wings black, with a large spot, and streaks of yellow. Rare Yorkshire.

DIAPHORA (STEPHENS).

Tue Spotren Musan (Diaphora mendier, Stuphran) appears the middle of May. Wings of the male one inch one-sixth to one-thrrd, female one inch one third to one-half; first pair in the male blackish, in the female white, with six or seven black scattered spots; second pair with three or four spots near the hinder margin; the abdomen white, with five rows of black spots: legs yellow. Cuterpillar, ash-coloured; feeds on varions water plants. Pupa brown, cnclosed in a case. Rather un. common. Yorkshire, Norfolk, Essex, and Kent.

\section{PENTHOPHERA (GETMAR).}

TuE Ren Motil (Penthophere Rubiu, (rismar). Not British

TuE Negro (Penth, migricans, Curtss) appears in June. Wings one inch one-sixth, brownish-black, with a yellowısh tint; the fringes and nervures darker; the feet silvery; the leg; and margins of the four or five last rings of the abdomen obscure yellow. Rare. Dorsetshire.

\section{PSYCHE (ScHRANE).}

Tite Brown Musidv (I'syche fuseti, Scurank) appears the end of June and beginning of July. Wings of the male cight lines to nine one-half, female two jines to two one-half; pale greyish-brown, without spots; the abdomen ash-coloured. The female without wings. Caterpillur fects on the sallow and hazel in June and the autumn, living in a case formed of pices of leaves. Very local. Highgate, Midulesex.

\section{FUMEA (HAWORTH).}

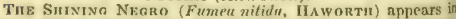
Juby. Wings five lines to five one-half, of a bright brown, ro. ther longish, with the margins ash-coloured. Caterpillar, yol. lowisl, with the head and a line on the three first segments chestnut colourcel. I'upn brown, in a case formed of bits of grass and leaves, Rare, Kent.

TuE SMALL Nvero ( $F$. Pulla, Strpnnxs) appears in June. Wings five lines, rounded, deep brown, without spots, and wjth hairy margins; antennxe rather pectinated, Rare. Kent. 
Tur Narno Bov (F, Muscelln, SтгрлеNg) appears in June. Wings rive lizes one-half to six lines, slizhtly oblong, deep black, transparent, unsprotted; the body covered with hair; the antenne brown. Not common. Essex, IIertfordshire, and Kent.

The Transparent Negro ( $F$. Bombycelli, Stepuens), Wings six lines to six one-half, rounded, slightly transparent, livid, sprinkled with brown. Very rare.

Thв Light Negro ( $\boldsymbol{F}$, petinea, Strpabss). Wings one-lialf inch, rounded, ashy.brown, transparent, unspotted, margined with brown. Very rare.

\section{NUDARIA (ITAFORTH).}

TIE MUSLIN (Nudaria mundr, IIAwoitii) appears in July and August. Wings nine to eleven lines, blunt, dingy white ; first pair with two waved brown streaks, and a brown spot between them; sccond pair spotless. Caterpillar, brown, hairy, feeds upon licliens. p'upa brown. Not uncommon. Ifertfordshire, Cheshire, Kent, and Surrey.

THB LACE-WING ( $N$. Hemerobin, STFPн ENS) appears the end of July. Wing one-half inch to five-sixths, transparent, spotless, with sealy margin and ycllowish fringe. Not common. Kent.

TuF ANtique Musuin ( $N$. Senex, Stepnens) appears in Jily. Wings two-thirds to threc-fourths of an inch, rounded, dingy yollow, first pair with a dingy spot a little beyond the middic, beyond which there is a very indistinet arched streak, composed of dusky dots, or small tingy lines; second pair with a crescentlike dingy spot in the centre. Kare. Cambridgeslire and Surrey.

\section{IIETEROGENA '(KNOCE).}

Trв AsRluUs (ITelerogenu Aselles, Stremins). Wings one. half inch to three-quarters, of a plossy brown, spotless, with dusky fringe. Calerpilles, egg-shaped, red, with a yellow line down the back, spotted with black; the sides green; feeds on the poplar. Pupa brown, enclosed in a case. Local. New Forcst, near Lyndhurst and Kimpton.

\section{LIMACODES (LATREILLE).}

TUE FEsToon (Limucodes Tesludo, STEPILNs) appears the end of June. Wings of the male two-thirds of an inch to eleventwelfths, female five-sixths of an inch to one one-third, yellowish grey ; first jair with two slanting dusky streaks ; colour leeper in the second pair. Cuterpillar, freen, egg shaped, smooth, with two

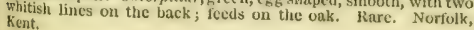




\section{NOCTUINA (RENIE).}

\section{LITHOSIIDIE (STEPHENS).}

CALLIMORPHA (LATREILLE).

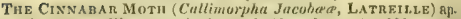
pears in May. Wings one inch onc-lialf to eleven-tweliths ; first pair brown on both surfaces, with a streak and two spots of a blood-red culour; second pair blood-red, irregularly dusky at the upper edge, fringe ashy-brown. Caterpillur, hairy, black, with yellow rings; feeds on the flowers of the rag-wort. Pupa blint, reddish, enclosed in a slight cocoon. Not common. Near Lon. don, Yorkshire, Cambridgeshire, Suffolk, Devon, Somersetshire, Cork, and Bute.

THE Ro*E Wing (C. rosea, LATReille) appears the end of June and beginning of July. Wings five-sixths of an inch to one one-third; red, or rose colour ; first pair with three waved, slanting, blackisly streaks, the last of which is near the hinder margin, and composed of distinct black dots. Caterpillar, brown, with whitish tufts; head reddish-brown, with orange down; feeds on birch, ash, and oak. P'upa brown, acute, enclosed in a strong web formed of silk and hair. Not common. Yorkslire, Ilertfordshire, and Middlesex.

\section{EULEPIA, (CURTI8.)}

The Featheren Lackey (Éulepin Grammica, CUtris) ap. pears in October. Wings one inch one-thirc to one half, yellow; first pair strealied with black, witl a black spot towards the hin. der margin; sccond pair with a central crescent and margins black. C'aterpiltur, brown, with a yellow streak on the back, the sides with two lines, one white and one yellow; the legs orange. red; feeds on black thorn, plantain, \&c. I'upa dusky. Rare. Berkshire and Anglesea.

Tue Sieve LAckEY (Fu. Crilurum, Curtus) appears in June. Wings one incl one-third to one-half, ashy grey, first pair with slanting rows of black spots; second pair darker. The corselt! white, with black spots. ('aterpillur whell young deep black. Very locul. Parley lleath, Hampshire.

\section{DEIOPEIA, (STEPIRNS).}

The Prattr Crimson (Deiopeia pulehellu, Sterines) appears the end of September. Wings one inch five-twelftins to threefourths; first pair straw yellow, with very numerous black and red square spots, disposed ncarly in a slanting arched serics; sccond pair snow-white, with a central bloteh, and the hinder margins black. Caterpillar, bluish gray, with black and red spots, and a broad white stripe down the back; feeds on mouse. ear, and forget-me-not. IRare. Yorkshire, I lampshire, and Sussex.

\section{LITHOSIA (FABRICIOS).}

The Oranae Lackey (Lilhosia Aurcola, Ochsenheimer) ap 
pears the midlle of July. Wings five-sixths of an inch to one inch one-sixth; orange-ycllow; first pair beneath with a very broad dingy patch, leaving the margins only yellow. Second pair paler. Caterpillar, black, with thrce pale yellow stripes on the back, and some white spots on the tail; feeds on the spruce and Scotch fir. Mare. Kent and Surrey.

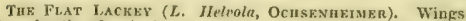
three-fourths of an inch to one inch one-sixth; pale yellow, with ashy and yollow margius, and yellow fringes. Very Rare. Es. sex and Hampshire.

THe Straw Lackey (L. fubu, Fabrerus). Wings one inch nac-third to one-half; straw colour on both surfaces, and with. out spots, Rare. Kent and IIampshire.

Tif Cinzanous Lackey ( $L$, Gilmeola, Ochaenueiser). Wings one inch one-third to one-half; first pair pale buft colour, ashy heneath; second pair pale yellow on both surfaces. Very rare. Kent.

THE LeAd coloured LAriry ( $L$. complana, HAwortu) ap pears the end of July or beginning of August. Wings one inch to one inch one-third ; first pair lead colour, with the upper edge, and second pair on both sides yellow. Caterpiltur, black, with two yellow streaks on the back, spotted with red and whitc, with a slight yellow line on cach side; fecds on the oak, ash, poplar, sloc, \&c. I'upu reddish-brown. Not uncomnon. Yorkshire, Essex, Devonshire, Kent, and Surrey.

THE BufF LACKey (L. depressa, OCHSEnMfimen) appears the middle of July. Wings one inch one-half; first pair pale lead. coloured ash, with the upper edge yellow; second pair on both surfaces yellow, with the base ashy. Caterpillur greyish brown, with the back yellow, with black spots; feeds on the Scoteh fir. pupa reddish. Rare. Kent.

THE DUN LAckry (L. griseola, IIAworti) appears the end of July or beginning of August. Wings one incl onc-quarter to one half; first pair with the upper edge straw-yellow. Second pair paler, with a tinge of yellow. Rather rare. Hertfordshire.

THe PAle LeAnen ( $L$, plumbeolata, Stephens). Wings one inch five-twelfths to one-half; first pair of a pale lcad-colour, with the upper edge slightly tinged with yellow; sccond pair yellowish-grey. Rare. Near London.

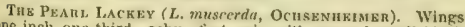
one inch one-third; R.shy ; tirst pair with several small black lots disposed towards the tip and middle; second pair spotjess. Very rare. Norfolk.

THk JuLy Lackey ( $L$. quadra, Fabricius) appears the middle of July. Wings of the male one inch two-thirds to five-sixths; female one inch two-thirds to two inches; first pair of the malc yellowish grey, deep yellow at the base, with the upper edge blue-black; of the female bright ycllow, with two deep blue spots in the middle. Catcrpillar, dusky, with rod dots and a 
black spot on the back, and black lines on the sides; feeds on bircl, fir, \&c. Pupa black, in a strong web. Plentiful. Essex, Kent, Surrey, Suffolk, Devonshire.

\section{GNOPHRIA (STEPHENS).}

Tun BLAck LActiby (Grophitrit Rubricollis, Stepnens) appears the midatle of July. Wings one inch one-twelfth to one-third, black, with the anterior margin of the corsclet bloorl-red. $C_{t h}$ terpillar, hairy, blackish, with deep black bauds; head-pitch black and two white strcaks: feeds on various kinds of lichens in Junc. Pupu redish.brown, in a grey web in July. Nut scarce. Essex and Kent.

\section{SETINA (STEPIENS).}

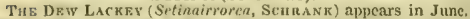
Wings of the male one inch to one inch one-fourth, female threefourths to one inch, ycllow; first pair with three slanting streaks of black spots; second pair with very few spots; corselet and extremity of the abtomen orange yellow. Cuterpillar black, with yellow stripes on the lack and sides; feeds on lichens. pepa red-brown. Rare, Kent.

TuE Swale Dew Lackiey (S, roscida, Scuranic). Wings of the male five-sixths to one inch, female two-thirds of an inch. Appears to cliffer from the preceding insect in size only. Uncommon. Surrey.

Thк Four Spot Lackiy ( $L$, plorina, Stepaens) appears the beginning of August. Wings of the nale one inch one-fourth, female flve-sixths to one inch; first pair whitish and klossy, with the upper edge and hinder margins yellow, with two black spots, one on the upper elge, and the other on the inner margin; second pair above dusky; margins on both sides yellow; bencath whitish yellow. Not common. Essex, Kient, and Surrey.

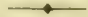 \\ NOCTUIDE (STEPHENS).}

\section{TRIPIIENA (OCHSHNREXMER).}

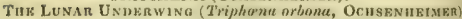
appears the end of Jume and beginning of July. Wings one incil seven-twelfths to two-thirds ; first pair liver-lorown, with dotted streaks; second pair of a decp yellow, with a central black cresecnt and marginal streak. Caterpillar greenish, with black spots on the sides. Not scarce. York, Salop, Essex, Kent, and Surrey.

The Criscrent Unnerwino ( $T$, subsequ, Ochsinneisea). Wings one inch two-thirds to threc-fourths, grey-brown, with an obscure kidney-shapel spot and black streak at the tip of the first pair ; second pair ycllow, with a dusky central crescent and marginal band. Rare, Scotland, 
THE BRIDE-MaId ( $T$, Promubf, Ocusenezimen) appears the beginaing of June and midule of July. Wings two inches to two inches one-fourth or one-third ; first pair of a cloudy grey ; becond pair bright yellow, crossed with a narrow black band. C'uter. pilker, greenish, with two interrupted black lines on the back ; feeds on the primrose, violet, airicula, cabbage, Re. found throughout the winter beneatil stones, clods, ke., in the day. time, and changes to a reldisls pupa ahout April or May. Common. Durham, York, and South of England.

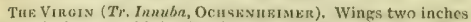
to two inches one-third, of uniform colour; upper wines liver brown; under wings yellow, with a black submargimal streak. Probably a varicty of $T r$. Pronuba. Common.

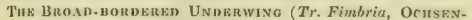
newsit) appears the cud of June and beginning of July; first pair of a pale grey, with waved streaks of a lighter colvur; second pair clear yellow, with a very broad black marginal band. Caterpillar buft grey, with a recldish liead, a jatle line on the back, and black spot on the spiracles; feeds on the prinrose, violet, yotato, Rc., in spring and antumn. Rare. Yorkshire, Derbyshire, Norfolk, Suffolk, Kent, and Devonshire.

TUE SUALL-BOTnERED UNDERWINo (TH. Interjerte, OCusRNnEIIER) appears in June. Wings one inch one-sixth to five. twelfths; first pair of a dingy red, with various indistinct strenks of black dots, and a clouble one towards the hinder marrin; secomd pair yellow, with a black circumference. Nut common. Hertfordshire, Iissex, Kent, aud Surrey.

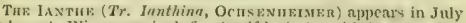
nr Aurust. Wings one inch five twelfths to two thirds, erey; first pair variously banded with dusky, with white crescents in the middle in place of the ordinary stizmata; second pair with the base and broad marrinat band decp black, aud the centre bright nrange jellow. Caterpiller whitish, with waved dusky streaks and black spots posteriorly; feeds on chickweed, \&e. Pupu brown. Not common. York, Suflolk, Essex, and Warwick.

\section{CERIGO (STRPHENS).}

Thr Straw UNDeniving (Cerigo tealu, Strumens) appears about June. Wimps one inch onc-half to three-fonrths, dusky varied with grey; first pair with waved stronks, bortered with black; sccoral pair straw colour, with a broad dusky margin. cuterpillar whitiul, with a black stripe on the back, feeds on goat's beard. Nut conmon. Norfolk, Essex, Middlesex, Kent, and Surrey.

\section{LYTAA (STEPHRNS).}

Tuk Six-strine lRestic (Litce umbrosu, STEPunNs) appears the end of July. Wings one inch one-third to two-thirds, rosy frey; first pair with six dusky streaks; sccond pair with a broad dusky margin. ('aterpillur greyish white, with a dingy stripe on each side. Not common. Salop and lient. 


\section{CIIARABAS (STEPHENS).}

TuE TuRn Rustic (Churatas Cespitis, Stupitend) appears in September. Wings one inch one-third to seven-twelfths; first pair brownish black, with three whitish waved streaks, margined with black; second pair freyish white at the base, with dusky clouds towards the nargin. Cuterpillur browuish, with three pale limes placed lengthways; fecds on grass. Scarce. Kent.

TuF Autumal Rustic (Ch. confinis, Stepuens). Wings one inch five-twelfths; first pair indistinetly inclented, pale greyish brown, with two slanting blackish streaks and one whitish; second pair greenisi white, Rare. Locałity unknown,

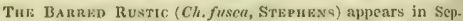
temlyer. Wings one inch one-third to seven-twelfths; first pair hlackish brown, with an indistinct somewhat triangular band in the middle, and a streak at the hinder margin; second pair in the male whitish, in the female brown or dusky. Not common. Kent.

THE BrACk Rustic (Ch. Rithiops, STEPHiNs) appears in June. Wings one inch two-thirds to five-sixths; first pair black, with a broad dark band darker tinted in the midale, stigmata very indis. tinct, the hinder one extermally margined with yellowish; second pair in the male white, margined with black, in the female dusky. Kare. Cumberland, Kent, and Devoushire.

THF ANther ( $C h$. Graminis, Sternens) appears the begil. ring of July. Winfs one inch one-sixth to one-half; first pair greyish brown, with a whitish line branching into three towards the posterior angle, with pale stigmata, and slender black lines towards the tip. Colerpillur dusky, with yellow streaks on the hack and sides, feeds on grasses, (except fox-tail grass), and changes into a brown shining pupr towards the end of June. Not common. Huatingdonshire, Surrey, and Devonshire.

\section{RUSINA (STEPHENS).}

Tra Brown Rustic (Russina fermginea, Strphexs) appcar towards the end of June. Wings onc inch one-half to two-thirds, first pair rusty grey, with four waved streaks and several paic spots on the upper edec; second pair pale greyish white. Cuter. jillur dingy brown, witli yellowish lines on the back and sides. l’upa reddísh. Hare. Kent.

\section{AGROTIS (HUBNBR).}

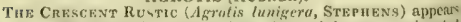
in June. Wings one inch two-thirels; first pair brown, variegated with yellowish, having two doulble lackish streaks and a yellowish crescent formed by the anterior stigma, which is dusky towards the upper edse, and lright yellow towark the inner nargin; second pair cream white. Rare. County Cork.

Tus IIbart and Cleun Rustic (A. corticen, Oensfantamen) appears the eud of June. Wings one inch one-third to two. 
thirds; first pair pale errey, with the ordinaty stigmata interiorly grey, exteriorly black; sccond pair dusky, with a central crescent and nervures darker. Thorax grey and white. Very vari. able. Rather scaree. Salop, Norfolk, IIertford, Kent, Sussex, and Devonshire.

Tul Prari. Underwino ( $A$. atru, Ochszminimer) appears in September and October. Wings one inch five-sixtlis to two inches ; first pair ashy grey, with the three ordinary stigmata very indistinct, and a paler spot at the tip; second pair dusky white, inged with violet, with the nervures and the hinder margin, especially towards the posterior angle, dusky. Rare. Essex, Hertfordshire, and near London,

TIE Conn Rustic (A. Segetum, OcIsenikimar) appears in June. Wincs one inch one-half to cleven-twelfths; first pair rusty greyish, with rather indistinct waved streaks; second pair whitish, aud so variable in its colour and markings, that it has been multiplied into not less than nine species. Cinterpillut dusky, with a pale line on the back and on each side, with four or five black spots on cach ring; found at the roots of corn, and in May changes into a dusky brown pupu. But too common in some districts. Hertfordshire and Suffolk.

Thi Dark Sworu Guass ( $A$, suffusa, Ochsenuzimer) appears in Junc and July. Wings one inch three-fourths to two inches; first pair grey, clouded with brownish, with a broad dusky band in the middle, and the hinder stigma spine-like, C'aterpillar ashy frey; found at the roots of grass in May, and towaris the end of the month changes into a dusky pupa. Not uncommon, but local. Essex and Kent.

The Subtriraneous Rustic (A. anmexi, OChsenfeimer) appears in June. Wings one inch two-thircls; first pair greyish brown, paler at the base and hinder margin, with the stipmata connected by two black confluent lines; second pair pearly white, with the nervures and mugins brownish. Rare. Near Loudon, Essex, and County Cork.

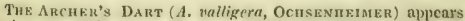
in August. Wings one inch one-third to two-thirds; first pair grey, clouded with dusky, the upper edge with whitish spots, on the hinder margin a streak composed of arrow-shaped black spots. Cuterpillar ashy grey, with four black spots on each segment; feeds on grass. Scarce. Dublin, Glamorigan, Norfolk, near London, llants, and Devonshire.

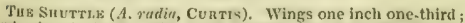
first pair jale dusky, witl three stigmnta, of which the two anterior are small and shutte-staped, and the exterior large and kidney-shaped; the upper margin is dotted with brown and white. Second pair whitish. Probnbly a varicty of $A$. Rarivin. Not common. Derbyshire, IIants and Devon.

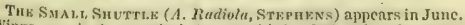
Wiags one inch one-sixth to one-third; first pair asliy grcy, the base with a dusky-square patch, and another behind the B 2 
middle; the anterior stigma longish and acute; of the female with a pale cloud towards the middle of the upper cdere; second pair white, with dusky nervures; female dusky, with a darher central crescent. Rare. St. James's and Greenwich Parks, Norfolk and Devonslire.

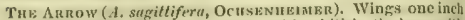
five-twelfths; tirst pair grey, clonded with whitish, the base with an furrow-shaped black line, and another beneath the orliuary stigmata; second pair milk-white. Rare. Near London.

Tни Line Dart (A. lineolata, Cunts) appeats the midale of August. Wings one inch four lines to one-half; first pair reddisl brown, stigmata whitish, and a streak on the hinder margin of wedge-shajerl black lines; second pair whitish, with a dusky border. C'aterpillor slining grey; found in June under stones, sc. Rare. Dublin and Kent.

Tue Pupil DArt (A. papillatu, Curtis) eppears in July. Wings oue inch five tweliths; first pair brownish, with two somewhat waved streaks, between which the colour is paler; two of the stigmata somewhat ocellated, and the third teliform. Rare. Iruntingdonshire, near London, and Devon.

TuE EAgb: (A. nquilinn, Ocusknstmbu) appears the middle of July. Wings one inch five-twelfths; first pair ashy, streahed with black, the uypuer edge spotted with black at the base, and with white towards the tip; second pair in the male whitish, in the fomale a-hy. Cuterpillar, ashy, head reddish, sides dusky; feeds on the bed straw. Scarce. Near bundon and Gilamor. ganshire.

THE WIEAT DART (A, Tritici, OCHSEnHRMIR) appears in June or July. Wings one inch five-twelths; first pair pale dusky brown, with the ordimary stigmata paler, and a streak towads the hivder margin composed of wedge-like spots, and a white line placed lenglitways. The teliform stigna is conspicuous from its black edging, second pair of the male whitist, of the fentale pale ash, with the margin dusky. Cateryillur, pale frey, with paler lines; feeds on corn in May. Not searee. Near Londen and Whittlesea-Mere.

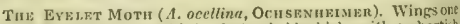
inch one-fourth to one-tlirel ; first pair blackish, with a shortish ashy line placed lengthways, two black spots and two pale-culoured streaks. Rare. Dublin, Kent, and Hants.

TUE Wrnok-BAR (A. euneigern, CunTra) appears the beginning of July. Wings one ineh one-quarter to five-twelitis: first pair greyish brown, with three stigmata and a streak of brown wedge-like spots towards the himder margin; second pair whitish, with the nervures and margins dusky. ScarebMiddlesex and Kent.

Thi Vkinza DARт (A, venosa, Stupuse) appears in July. Wings one inch five-twelfths; first pair brownish grey, with thrce slanting asty streaks, at the hinder margin is also a whitis 
streak, the nervures pale ashy grey; second pair of the male ash-coloured, and the nervures darker. Rare. Edinburgh.

TuE (iarura Motu (A. Hortorum, Stemexs). No description published?

THe Br.Ack QUAкел (A. nigricans, CUnTts) appears the end of July and beginning of August. Wings one inch one-fourth to me-half ; first pair dusky, with three streaks, and stigmata paler; the third stigmata well marked with a black margin; second pair whits, with the nervures, margins, and a central crescent dusky. Cuterpillar trown and shiming, with black spots and a yellowish tine on the sille; found in June. Not scarce. Lon. don and lluntingdonshire.

THW DaRk RUstc (A. fumese, HAworti). Wings one inch one-quarter to one-third, blackish, variously streaked with black and palc, with the two ordinary stigmata borticred with yellowish, the teliform stigma is wanting. Ferhaps only a varicty of $A$, nigricuns. Rare. Near London and If untingdonshire.

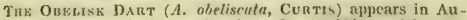
gust. Wings one inch one-fourth to five-twelfths, red brown, with a black triangular spot before the first stigma, and a pale square spot between the stigmata. Rare. Near London and Kent.

THV RURAJ. DART (A, ruris, OCHS KNIEIMER) appears in August. Wings one inch one-third to two-tlirds ; tirst pair pale brown, with strcaks, and the three ordinary stigmata yellowish whitc. Rare. Huntingdonshire and Kent.

THE WHit: LiNk (A. dubin, IlAworth) appears in Angust. Whings one inch one-half, brown or black with streaks, and the ordiuary stigmata darker, and a white well marked waved streak towards the hinder margin. Probably a variety of $A$, ruris. Rare. Near London,

The Gornuc Dant (A. subgothica, Strpukss). Wings one incl oue-third to one-halt; first pair greyish brown, with the upper edge at the bake, a longitudimal dash placed lenkthways, a marginal band towards the hinder margin, and the stigmata, pade. Scarce. Nortolk, Hear London and Devon.

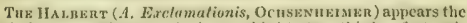
end of June. Wings one inch one-third to two-tlirels; first pair brown, with the streaks and three ordinary stigmata binek. C' terpillar dull red brown, with black spets, and a jale red line on the luack; fects on groundsel. Yery common.

Tun C'ovo Motu (A. nelulosa, SteruzNs) appears in July. Wings of the mate one incls one-third, female one incls one-sixth; first pair whitish-grey, with dusky clouds at the base, the hinder margin darker, with a white waveit streak; the secoad pair of the male white, of the female ash colour. Kare. Devonslire.

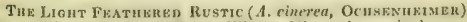
appears the begimning of Jume. Wings of the male one inch one. 
half to two.thirds, female one inch one-third; first pair ash. coloured, cloukled with brown, posteriorly of a darker hue, with two indented black streaks; second pair whitish, corselet anteriorly black. Caterpillar greenish-brown, with three real stripes on the back, the head brown and shining, legs yellowish white. Not common. Shropshire, Berks, Kent, and the Isle of Wight.

\section{GIRAPIHPHORA (HUBNER).}

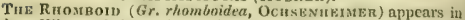
July. Wings of the male one inch two-thirds, fermale one inch one-sixth; first pair reddish brown, tinged with rosy, with a brownish-rhomboidal spot, and a triangular one near the stigmata; the antenne of the male are pectinated. Rare. Huntingdonshire.

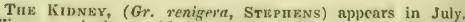
Wings one inch one-third to one.half ; first pair blackish grey, with seattercd white dots, and darker slanting lines; second pair ashy brown, paler at the base. Rare. Forfarshire, Westmoreland, and Derbyshire.

Tuk Sculker (Gr. lutens, STEPHENs) appear's in summer. Wings one inch one-half; first pair glossy ashy black, with waved and very indistinet brownish streaks, the ordinary stigmata are very indistinct; second pair ash-coloured, with whitish borders. Rare. South of Scotland.

THe Prropurous (Gr. myrophila, STEPrens) appears in July. Wings one inch one-half to two-thirds; first pair ashy, streaked, and spotted with brown; second pair glossy brown. ('ateryilin dull brownish-grey. Rare. Near Londion, Shroushire, War. wickshire, Zetland, and Lanarkshire.

Tre Crescent Stripen (Gr. lenulina, Steprens). Wings one inch two-thirds, brown, with four indistinct pale streaks, edged with black, as if composed of minute crescents; no ante. rior stignma; there is a row of very minute black sjots on the hin. der margin; second pair ashy, having a dingy border, with a pale streak on the margin itself, fringes whitish. Rare. Cambridgeshire.

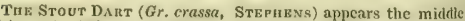
of August. Wings one inch one-half to three-fourths; first pair shining brown, slightly clouded with black, the third stigmn indistinet, the streaks paler than those which generally appear in this species; second pair whitish, with the nervures and margin black-brown. Scarce, Scotland and Norfolk.

Tul Auove (Gr. Augur, Ocusewuxtmen) aplears the berin. ning of July. Wings one inch seven-twelfths to three-fourths; first pair dusky redilish-lorown, with black waved streaks, two black riugs, and one kidney-shapefl, with a black margin and ashy midtlle; second pair dusky, tinged with red, and a cresecnt on the dise. Not scarce. Essex, Hertford, and Kent. 
The BRUNetтs (Gr. brunnea, Hawonta) appears the end of July and heginning of August. Wings one incli one-half to twothirds; first pair purplish brown, with a dark waved band at the hinder margin, the hiuder stigma yellow, and a central black spot; second pair dingy brown, with a spot in the centre; fringe of all the wings dingy brownish. Caterpillar brown, spotted with white, with a bluish line on the sides; head black, with two white streaks; feeds on the pea. Not scarce. Salol, Kent, and Surrey.

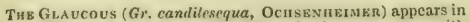
july. Wings one inch one-half; first pair glaucous-grey, with black streaks, of which the exterior is indented, and the posterior paic and somewhat waved; second pair dusky ash; the border of all the wings greyish brown. Caterpillar dingy brown, streaked with white and red; is found in May. Rare. Kent.

Tuz Trune Srotren (Gr.tristigma, Ocusanukman) appears in July. Wings one inch one-half to two.thirds; first pair dusky brown, with a black spot between the stigmata, another at the base of the anterior stigma, and a third of an irregular form at the base towards the inner margin. Caterpillar dusky, with a white line on the back and on cach side; feeds on the dandelion in May. Scarce. Kent and Surrey.

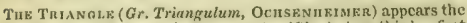
end of July. Wings one inch seven-twelftis to two-thirds; first pair greyish purple, spotted with black, with a black spot on the upper margin towards the tip, the stigmata and four pale streaks margined with black; second pair dusky brown. Caterpillar reddish ash, with a dusky line on the back and a reddish one on the sides, with two brownish stripes on each joint; in June it changes into a brown pupu. Not jlentiful. Yorkshire, Suffolk, Essex, Kent, and Sussex.

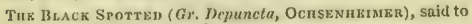
be Britisli on doubtful authority.

Tü Tricomas ( $G r$, baja, HAwortii) appears the cnd of July. Wings one inch one-half to two-thirds; first pair rusty grey, abscurely clouded in the midclle, with a minute black dot at the base, and a patch on the upper edpe near the tip; second pair dusky brown, paler on the hinder margin, Caterpillar varied with ashy and brown, with three white lines on the back, and a yellow one on the sides; feeds on the nightshade, and changes to a propa in Juae.

The Barnu Cuestuot (Gr.erythrocephnla, HAworti) ap. pears in July. Wings one inch one-tlird to seven-twelfths; first pair rusty grey, with a brownish square chestnut spot between the stigmata, between which and the hinder margin is a waved chestnut brown band; second dusky brown, with a darker central crescent. Caterpillar grey brown, with a dusky stripe on the baek, and two white lines on the back and on the sicles, and a few white spots; fects on the plantain(?) Occurs in M1ay. Rare. Kent and Surrey. 
THE PRnunse (Gr. festiun, IIAwortis) appenrs the end of June and beginning of July. Wings one inch one-fourth to ore. half; first pair clouked with grey or yale brown, with several angular spots, which are of a decper hue, or black towarcls the stigmata; second pair ash colour, with a central dusky crescent. Cuterpillar reddish yellow, with yellow spots, and a yellow line on the back, and two dasky limes on the sides; fecds on the primrose, and changes to pupu in June. Rare. Kent and Surrey.

The BeAck C. (Gr. C. nigrum, OCHsfanumarn) apjears the end of June and begrinning of July. Wings one inch one-fourth to one-half; first pair ashy brown, with a black line at the base, and another at the upper edge towards the tip; in the miclale a large bow-like black patch extermally pale; second pair whitish or ycllowish white, with the hinder margin dusky. C'aterpillar varicd with ash and brown, with a pale longitudinal line, and several transverse ones on the sides; fecds on chickweed, marsh willow-lierb, and spinach; changes to a brown pupa in May.

TuE Musrve ( $G r$, musirn, Ocnsexnermzr). Wings one inch one-sixtli; first pair brown, the base witl a black waving line, and a whitish band at the superior margin; colselet with a black band: sccond pair whitish. (aterpillar yellowish green, with a brown head, a dull green line on the back, and two whitish lines on the sides. Very rare.

Tre White Spox ( $G r$. nlhimaruln, StepukNs) applears in September. Wings one inch five-twelfth to seven-twelfths; first pair reddish brown, varicgated with purple, with a pale band on the upper edge, a black line on the base, and a longish central hlackich brown dash, in which there is a round white spot; sccond pair glossy, of a dusky ash colour, with faint slanting streaks and dark margins. Rarc. Iluntiugdonshire and liampshire.

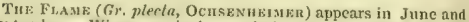
September. Wings one inch one-sixth to one-fourth; first pair of a brownish jurple, with a black line on the base, and with the upper edge from the base to the midkle and the stigmata flame yellow; second pair whitish. Cnterpillur green, with a brown licad; necurs in May and August. Not scarce. Essex and Devonshire.

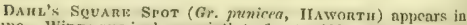
sune. Wings one inch one-sixth to five-twelfths; first pair rosy grey, streaked with dusky, with a dusky square spot between tie stigmata, and another on the upper edge towards the tip; second pair ash colour, with a dusky central sunt; the borders of all the wings reddish. (Interpillar reddish brown, with a yellow stripe on the back, and pale streaks on the sides, which are sprinkled with yellow and brown. Not common, Salop and Essex. 


\section{SEMIOPIIORA (STEPHBNS).}

The HEßREW (S. gothica, STEPIENS) appears the middle of April. Wings one inch one-fourth to seven-twelfths; first pair Grejish brown, with an arched black spot and square black line in the middle; the pale margins of the stigmata are only visible. futerpillur pale green, yellowish on the back, with a white line and few dusky sjecks on the side; fecis on oak, honeysuckle, woodbine, \&c. Not scarce. Iessex, Middlesex, Kent, Surrey, and Shropshire.

\section{ORTHOSIA (OCHSENIEIMER).}

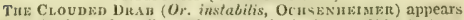
the begiming of $A$ prit. Wings one inch five-twclftis to twothirds, greyish brown, or ashy clouded with grey, with a central rusty-brown band, the ordinary stigmata markined with pale ash, and the streak at the hinder margin simple and whitish. Caterpillar green, with a white line on the back and a yellow one on the sides; feeds on the oak. Plentiful. Essex and Surrey,

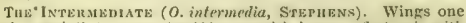
inch one-sixth to seven-twelflis, greyish brown; first pair with three equidistant tarker bands, two rings, and the ordinary stigmata pale, and a double streak on the linder nargin; the antenna of the male strongly pectinated. Rarc. Surrey.

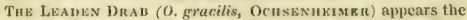
beginning of Aprit. Wings one inch ouse-half to severs-tweltths, lead colour, and cloued with grey; first pair with an indistinct streak towards the linder margin, and several greyish syots marrined with pale; second pair dusky. Caterjillar green, the sides yellowi:h, with a black spot and four obscure dots on each ring, which is yellow; feeds on the oak, willow, bramble, \&e.; changes to a jupa in July. Ratlicr scarce. Essex, Keut, and Surrey.

Tir: Twin Spot Drab (O, munda, Ocusknmkmer) appcats in $A$ pril. Wings one inch seven-twelfths to two-thirds; first jair asliy grey, somewhat clouded, with a pale streak at the hinder margin, having two or three twin spots. C'aterpillar varied with black and krey, with a red line on the sides; fecks on the oak, clm, sloe, and fruit trees, and about June clunges to a pugha. Kare. Essex and Surrey.

TuE Powmeren) Quaker (0. sparsa, Curtis) appears the heginning and end of April. Wings one inch seven-twelths to two-thirds, ashy krey; first pair with very minute dusky dots; behind the stipmata is an arclicd series of black spots, and towards the hinder margin a dusky streak margined with whitish. C'aterpillar green, with a pale stripe on the back and sides; feeds on the tops of willows, and changes to a pupa in July. Rather uncommon. Essex, Hertfort, lient, and surrey.

THe Pale QuAKer (O. pallita, CurTts), Wings one inch five-tweifths to one-half, uniformily of a pale reddish brown: first pair, the ordinary stigmata have only a very slender pale 
margin ; between these and the hinder margin, a straight slanting brownish streak, externally edged with a pale tint; bchind which, and near the hinder margin, is a row of very minute brown spots. Probably only a variety of 0 . sparsa. Surrey.

TuE Steany Quazen (O, stabilis, OcuszNntimar) appears the beginning of April. Wings one inch one-fourth to onc-half, rusty grey; first pair, the stimmata with yellowish margins, an external pale strcak edged with dusky, and a row of small black clots on the hinder margin. Caterpillar yellowish, with prim. rose yellow lines and blue head; fecds on the oak, elm, beech, lime, poplar, cherry, \&c. Common. Salop and Essex.

Tre Blossom Unneriving ( $O$, mirioso, Ochsenieimer) appears the end of Mareh. Wings one inch one-third to one-half; first pair pale ashy red, with three waved strealss and? broad cen. tral band vermilion red; second pair rosy white, with a central dusky spot, aul in the female particularly, an interrupted dusky band behind the middle. Caterpillar black, with an interrupted yellow line on the sites; the head with; three streaks; feeds on oak and birch in May and June, Rare. Essex and Kent.

Tur Divarp Qvaker (o. cruda, Ochsinthimer) appears the end of March. Wings eleven-twelfuis to one inch oue-fourth; first pair brownish ash, the base with scattered brown spots, thic stigmata olsscure, clusky, margined with erey, and two indistinct streaks of reddish spots; sceond pair thisky red. Caterpillar reddish brown, sprinkled with white on the back, with a yellow. ish line on the sides; the head green with white and black; feeds on the oak, wild rose, \&e., in June. Plentiful. Near London.

TIE TINy QUAKER (O. pusillt, CurTIS) appears the end of March. Wings one inch, grey, rounded or retuse, the stigmata contiguous, and a stout reddish, sometvliat interrupted linc, passing from the anterior stigma to the base. Rare. Surrey.

Tus Brown Spot Pinion (O. lituri, Ochsinhimer) np. pears the end of Septemlser and beginning of Uctober. Wings one inch one-sixth to one-lyalf, greyish brown, with five black spots or patches on the upper margin. Catrrpillar green or yellowish, with a dark stripe on the back, edged with white, and \& whitish line on the sides; the head brown; feets on sloe, birch, willow, rose, trefoil, \&e., in May and Jume. Scaree. Yorkshire, Derbyshire, Fissex, and Hertfordshire.

The Chestrut (0. pistacina, OchsвNHAMER) appears in September. Wings one inch one-fourth to one-half, yellowish brown; first pair with five very indistinct streaks composed of yellowish brown spots. Caterpillar green, with a whitish stripe and pale spots on the sides; feeds on the Centaurea scabiosa and Ranunculus bulbosus. Scarce, Kent.

The Lunar Underwino (O. lunosa, Curris) appears in Sep. tember. Wings onc inch one-third to one-half, greyish brown; first pair with a distinct streak of black spots towards the hinder margin; second pair white, with a central dusky crescent and 


\section{CONSPECTUS OF MOTHS.}

submarrinal band. Not unconimon. Yorkshire, IIertford, Essex, Kent, Surrey, and Devon.

TuF Run Ling Quaker ( 0 . Lota, Ochsenumimer) appears in nutumn. Wings one inch one-fourth to one-half, ashy brown; frst pair with a black spot behind the middle; a brown streak towards the hinder margin elged with whitish, and the stigmata with bright brown borders. Caterpillar greyish ash, with white strenks, slightly bordcred with black, and a reddish line on the sides; feeds on willows. P'upa enclased in a solid casc. Not common. Essex, Cambridgeshire, Devonshire, and Yorkshire.

Tine Yellow Line (O. flavilinea, StepHeNs) appears the end of September and beginning of December. Wings one inch onethird to five twelfths, brownish; first pair with a slanting, but very straight ycllowish strcals, edged internally with dusky brown, and a brown spot at the base. Caterpiller feeds on plantain and chickweed. Not common. Near London, Devon. shire, and Hampshire.

Tue Brick (O. mecilenta, Ochsennfimr $)$ appears the end of September. Wings one inch one-third to two-thirds, reddish brown; first pair with four darker streaks, and a brown spot at the base of the first stimma. Caterpillur reddish brown, with dusky spots, and a faint whitish streak on the back and sides; feeds on clm and oak. Rather scarec. Suftolk, Ilertforcishire, Surrey, and Hampshire.

THE Upsuon (O. Upsilon, Ocnsknuknar) appears in July. Wings one inch one-fourth to onc-half, ashy-brown; first pair with a black streak at the base, and a double one in the middle; the stirnata pale, between which is a black mark resembling a $Y$ or $V_{i}$ second pair with a central cresecnt and margin of a darker tint. Caterpillar of a dull brown, with tluree pale stripes on the back, and several darkish spots on the sides; fecis on willows and poplars. Not common. Cambridgeshirc, Middlesex, and Surrey.

\section{MYTHIMNA (OSCHSENHEIMRR).}

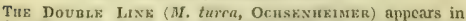
July. Wings one incin two-thirds to thec-fourths, defiened and rusty brown; first pair with numerous indistinct dusky dots; a brown incurved streak before, and another slantins and a little wated behind the whitish erescent, which is in the place of the hinder stigma; the first stigma is wantiug. Caterpillar pale red, with a white line on the back, yellowish white underneath; head brown; feeds on Junces pilosus. Kare. Epping forest, near Bristol, and Surrey.

TIE GREY BRIGHT EYK ( $M$. griseu, Hswortit) appears the beginning of July. Wings one inch five-twelftis to seventwelths, of the niale grey, of the female red, with a white eentral spot and an arched streak of very minute brown spots at the hinder margiu. Caterpillur dusky, with a redulsh lime on 
the sides; fecls on plantain and chickweed. Not conmon. Essex, Suftulk, Cambriclgeshire, Kent, and Hamp̧shire.

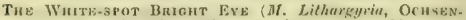
netмk R) appoars in July. Wimgs one inch one-twelftls to fivetwelfths, palc yellowish brown; frst prir with two nbscure streaks, and a white central spot. f'aterpillar kreys, streaked with white, and dotted with black, with three white lincs and the first segment brown; feeds on plantain. Rare. New Forest.

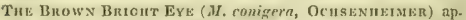
pears the end of July. Wings one incly one-tlirel to tivetwelfths, rust brown; first pair with a very white three-cornered spot in the middle between tivo brown streaks. (uterpillar grey, with white and black streaks; the leed brown; the first segment black with three white streaks; feets upon chickweed and grasses. Not searce. Derbyslire, Lssex, 11erttordshire, Kent, Surrey, and Devon.

\section{SEGETIA (STERIENS).}

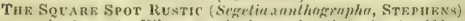
appegrs in August. Wings one inch one-fourth to five-twelfths; first pair chestmut brown, with a square spot between the stig. mata, aud three indistinct brown streaks, and a pale pre towards the hinder rmatkin; second prair whitish, with a yellowisk fringe. Caterpilltr dull yellow, with a pale line on the side, streaked and dotted witl? black bchind; head brown, with three dlark streaks. Pleutiful. Near London, Essex, Salop, Kent, and Sussex.

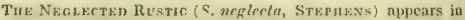
September. Wings one incil seven-twelfths to three-fourths; first pair obscure ash colour, with streaks of very minute hlack dots; the posterior stigma with a bruwn spot, Rare. Kent and Ilampshire.

\section{GRAMMESI (STKPHENS).}

THE TaIPJ.k-1Nks (G. trilinen, STBPHENS) appears the end of June and betinning of September. Wings me inch one-fourth to five-tweliths, whitish grey ; first pair with three slanting and equidistant clusky streaks, with an indistinct one at, the base; sccond pair dushy, with a frey ftinge. C'nterpuller anls kscy, with a pale stripe on the sides; feeds on the plantain. Not scaree. Hertfordshise, Kent, and surrey.

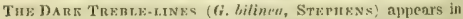
July. Wimgs one inch one-third to tive-tweltths, grey ish brown; first jair with two nearly straight clingy streaks, hetween which is a very indistinct stigma. Very rure, Essex, Kent, and Surrey.

\section{CARADRINA (OCHELNHEIMER).}

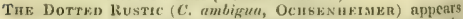
in June. Wings one inch one-third to five-twelftis; first pair 
brownish grey, with three indistinct dingy streaks, and a pale one towards the hinder margin; the stipmata with a white border; second pair whitish. Cinterpillar rusty red, with a brown head; fecls on dandelion and plautain. Searce. Kent, and near London.

Jisszu Dotren Rustc (C. Redacta, Stuptens) appears in Jume. Wings one inch use-sixth to one-third, grey; first pair with three indistinct diney streaks and a pale one towards the hinder markin, the stismata with whitish margins, smaller than the preceding, and its markings more indistinct. Not rure. Đerbyshire and Kent.

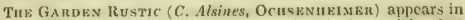
June. Wincs one incli one-sixth to one-fourth, brownish ; tirst pair with a hroad brown indintinet streak towards the hinder marein, and the ordiuary stigmata brown and distinct. ('uter. pullar ash frey, with a reddish line on the sides, and a brown head; feeds on plantain. Rather scaree. Near Londor, Hampshire, and Devonshire.

Tus Waven Rustic ( $\boldsymbol{C}$. implexa, StepHens) appcars in July. Wings one inch one-twelith to one-sixth, rusty frey; first pair with four distinct darker streaks, and a fifth very pale aud waved behind the posterior stigma; the ordinary stigmata brown. Not scarce, Kent.

The Grey RUstic ( $C$. lamis, StepHens) appears the beginning of July. Wings one incis one-fourth to one-tliird, very obscure, the streaks nearly as in the Square Spot Rustic, but more slender and indintinct, scaredy visible unless by a lens, the anterior stigma wanting, the posterior kidney-shaped, one haviner only the margin apparcut, with a black dot at the base. The fringe of the first pair dull redclish, of the second paler. Very rare. Near London.

Tul Dinov Rustıc (C. sardidr, Stipurss). Wings one inch one-thiral, clull reddish; first pair with two very indistinct streaks belind the middic, the mareins of the stismata alone visible, a maremal row of very mimute spots. Very rare. Lo. cality unknown.

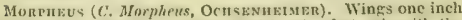
one-fourth to one-third, pale- jellowish ash, first pair with the ordinary streaks, and an external band more olsecure; second paur whitish, witl the margin and central cresecut dusky. Rare. Devonshire and IIertfordshire.

Tue Mutreen Rustic ( $C$. Sepii, IIAworti) apjears in June. Wings one inch one-sixth to one-third, grey, clouted with a broad dusky band towards the hinder margiu; the stigrmata indistinct, brown, and in form of spots; second pair rather large, whitish, with a dusky marginal streak, fringe white, tinged with yellow. Cuterpillar reddish-brown, with a yellow line on the back, ant rerldish streaks on the sides; feeds on the Convolvtulus Sepium. Cormmon. Near London, 
The MotTled Wil.ow (C. culicularis, HAworti) appears the middle of July, Wings one inch one-fourtb, ashy white, clouded with a waved streak on the hinder margin, composed of very mumerous triangular arrow-shajed red spots, edged ex. ternally with a paler colour; second pair whitish, with the margin and nervares dusky. C'aterpillur feeds on the Valeriana locusta, Common. Near London and fient.

Tue Pownkren Rustic (C.superstes, Ocuskviermkn). Wings one inch one-fourth to one-third, asliy white, powdered with brown, with a waved streak near the hinder margin reddish brown, and externally edged with pale, with a row of somewhat three-cornered black clots on the extreme marfin; fringe ashy. brown; second pair white, with the margin and nervures dusky, fringe white. Not common.

Tele Pearl Rustic (C. glorensu, Ochsmnneimea). Wings one inch one-sixth to one-third; first pair faint ash colour, with a black somewhat square spot between the ordinary stig. mata, and two short iuterrupted spots on the upper nargin, towards the base; second pair and fringe white, tinged with yellow. Not common. IIampshire and Devonshire.

\section{GLAEA (HUBNER).}

The Reb Chestnut (G. rubricesu, Stripnens) appears the end of Mareh. Wings one inch one-third to one-half, chestnut. red; first pair with the upyer edge palc, as far as the midclle, four waved dusky streaks, and the ordinary stirmata rather inflis. tinct; second pair reddish brown, with reddish fringe. Citer. jillar grey, with a palc back, and each segment with two white dots; feels on the fumex acuta. Very rare. Kent,

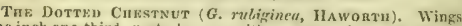
one inch one-third, rusty brown, with numerous irregular brown spots. Culcrpillar slightly hairy, bruwnish, with a black spotted line down the back, the hair grey. Very rare. Locality un. known.

Tuk SAtelite ( $G$. Sutelliti, Sткрнгns) appears in September. Wings one inch one-third to seven-twelfths; first pair chestnut red, indented on the hinder margin with brown streaks, the posterior one being considerably waved; in place of the posterior stigrma is a small white crescent-shaped spot, with a small white dot above it, and another below it; sccond pair blackish, with red fringe. Cuterpilter black or grecnish, with a narrow white line on the sides, and yellowish marks on the neck; feeds un the bramble, sloc, onk, beech, ke. Not uncommon. Essex, Middlesex, lient, Surrey, Devoushire, and Ilampshire.

Thi Bunerry (G. Vaecinii, Stzphess) appears in Septem. ber. Wings one inch one-fourth to one-third; luving the nervures rust-red, with brown streaks, and a row of red spots to. wards the hinder margin, placed on a broad pale chestmut-co. loured band; second pair dlusky, with red fringe. Caterpillar rusty brown, with a pale line on the sides, the collar aud tail 
black with white streaks; fects on the bramble, black and retl wortleberries, sce. Not uncommon. Ifertfordshire, Norfolk, Surrey, and Devonshire.

ThK Dark Chestant (G. spadicen, IIAworti) appears in September. Wings one inch one-fourth to one-third; first pair of an almost uniforn chestuut colour, but somewhat clouded with dusky, the upper edge towards the hinder margin with a few pale spots. Not searec. Near London.

THE Bhack Cifegtrout (G, subnigra, Stephing) appears in September. Wings one inch onc-fourth to one-third ; first pair blackish ehestnut, with a somewhat intcrrupted pale band near the hinder margin, composed of confluent white spots; second pair dusky, with the fringe slightly reddish ; the abdomen of the male less that. Rare, Near London.

The Net Chestnet (G. polita, Haworti) appears in September. Wings one inch onc-fourth to one-third; rust-red, with the nervures and streaks netted and powdered with ashygrey. Caterpiliar pale brick-red, with black dots; feeds on taraxacum.

AMPIIIPYRA, (OCHSENHEIMER).

Tye Copter Unverwive (A, Pyramider, Ochsentamer) appears the beginning of August. Wings one inch two-thirds to two inches; first pair brown, varied with prey, with three wared yellowish streaks, and towards the middle the anterior stigma encircled with white; second pair copper coloured, with the upper edge browr. (Caterpiller green, with a whitish line on the back and sides, and a large cone-shaped protuberance on the posterior segment; feeds on the oak. Rather scarce. Herefordshire, Essex, Surrey, and Hampshire.

\section{PYROPHILA, (STKPHENS).}

TuE Mousk ( $\mathcal{P}$. Tragupogonis, STEPHENS) appears in June. Wings one inch one-fourth to one-tlizd ; first pair mouse-brown, with three black spots in the middle; seeond pair livid brown. Caterpillar, green, with five white lines, and a few whitish spots on the sides; fceds on the goat's-beard, spinach, dock, larkspur, \&ic, Not scarce. Ifertfordshire, Warwickshire, and lient.

Tur Mahogany (P. totru, Stremens) appears in June. Wings one inch one-fourth to five-twelfths; frst pair deep brown, with thee indistinct brown sjots in the middle, and four white ones on the upper edige; second pair rusty ash. Cuterpillur sTeen, with a white line on the back, and two red ones on the sides, the head smnll; fecds on various plants. Scarce. Esser, near London, Somersetslire, and Deronshire.

\section{DYPTERYGIA (STEPHENB).}

TuE BIro's Wine (D). Pinastri, STEPIENS) appears in June. Wings one inch five-tweliths to one-half, black, with an ashy- 
streaked spot resembling an expanded bird's wing at the posterior angle of the first pair. C'aterpillur dull brown, sprinkled witl deeper spots, with some dusky slanting lines, and two pale uncs. Scarce. Norfolk, Middlesex, and Surrey.

\section{N/ENIA (STERIENS).}

THE DAR G Gotrie ( $N$, typica (STretivis) appears the ent of June. Wings one inch one-half to ten-twelfths, brown; first pair with white nervures, and three stigmata margined with whitish. ('uterpillas grey, the sides dingy, with three faint strcaks; feeds on the hound's tongue, nettle, willow, \&e. Prupn brown, cnclosed in a wel). Common. Shropshire, Essex, Huntimgdonshire, and near London.

\section{XYLINA (TREITschKE),}

Tue Grey Shourber KNot (X. Lambdu, Tuentscukf) apr pears in Autumn. Wings one incls one-half to two-thirds; first pair white, clonded, the base with a line terminating in two or three twigs, at the hinder margin a row of black spots; sceond pair deej brown, with the fringe palcr. Caterpillut downy, frecu, white-spotted, with a bluish line on the back; feeds on the oak. Rather scarce. Salop, Iertfordshire, Essex, and Sur. rey.

Tuk Peт (X. pulle, Ocusksmz1men) appears in August. Wings one inch two-thircls; first pair deep ashy grey, with an indistinct whitisi spot in the michle; second pair whitish, with luaky nervures. Cuterpillar green, with a whitish spot, and a linc of the same colour on the sides, Rare. Essex.

Tue Tawny Platon )X. semibrimpa, Stephens). Wingsone incli seveu-twelfths; first pair clouded, externally ashy brown, and internally brownish red; sceond pair ashy brown, with the margin, nervures, and a small central spot dusky. Rare. Surrey.

Tut Stone (X. petriforata, OcusknukayrR) appears in June. Wings one inch two-thirits to three-fourths, pale grey browa; first pair with grey and brown streaks, a dark brown liue at the base, and auotier towards the inner margin; the ordinary stigmata paler; second pair with an tndistinet slanting streak of brown spots a little behind the middle, and a dark crescent on the disc. Caterpither frecrs, with white spots, and a broad white stripe on the back, and a uarrow one on each side; feeds on tike elm, oak, sloc, lime, \&e. Rare. Near London and Devonshire.

TuE SHever Croun (X. conspirillaris, OruskvustmeB) ap. pears the end of May. Wings one incls one-lialf to seventwelfths; first pair streaked, varicd with brown and ash colour, and whitish towards the inner exlge; second pair snow white, with the nervares and hinder marrin dusky, fringe white. Caterpillar alull kreen, with a yellowish white line on the sides, cdged with brownish ; feedy on the Astragalus Omobrychis, \&c. Rarc, Kent and Bucks. 


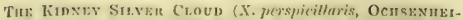
MFR epjear in June. Wings one jucl one-half, witl four brown stroaks, toothol belind with a simgle kidney-shaped common spot, the lower markin with a purplish tinge. (interpillar. sonewhat downy and rough, green, with a white line on the back. Rare. Kent.

Тнк FLA of June. Wimfs one inch one-quarter to five tweliths; first paiv yellowish white, with the anterior margin and stigmata brown, and a slanting double streak of black spots towards the hinder edige: second pitir of a pide yellowish brown, with the hinder marin spotted with brown. ('alryillur y (-llowish lornwn, black spotted, and strualsed with pale yollow and whiti-h, with $\Omega$ yellowish line on the back; the head brownish black; feeds on grasses. Nut searec. Essex, and near London.

\section{CALOCAMPA (STRPHENS)}

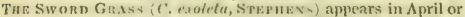
Mtay, and the mislle of Oeteober. Wings two incless to two inches one-fourth ; first pair woud brown, rather long, narrow, streaked with brows at the hinder edge, the interior at ikma olabong, the posterior car-shaped; second pair ereyish brown, with the markin

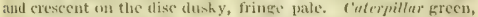
with large whits spots on the back and smaller ones on the sides, arita red one buneatls; feedsupon lettuce, spinach, brocm, bramble, asparagns, \&c. lather scarce. Oxfort, near LonUon, Kent, and Devonshire.

TH: Axтrotr: ( $($ : retustu, STFPHENs) appoars in eutumn. Wings one inch five-sills to two incles onc-sisth; first pair anteriorty pale brown, interiorly olscere brown, with an oblong

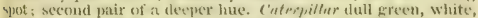
suotted with a yellowis line on the back and a whitish one on the side; stigmata rod; fecds on Carex, Rare, lient.

\section{XYLOPIIASIA (STEPITENS).}

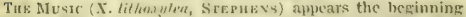
(1f July. Wings ome imoth three-fonaths to eleven-tweltths ; first pair pale, somewhat clotaled with dacky brown, with whitish and brown spots on the tupuer edge; the hinder edire irrestalarly rusty brown; sccond pair pale, with a central crosecnt and marein dusliy; the nervtres and spots on the margin brown. Caterpillar rreen, with whitisly spots and lines on the sides; feeds on the black thorn. Not scarce. Cheshire, Essex, Middlesex, Kent, and Surrey.

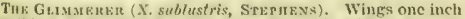
two-thirels to five-sixths, rusty ash; first pair with a spot on the upper edge, and the linder edige irregularly narked with rusty brown; second pair with a central crescent and streak behind, the middle darher. Kare. Sussex.

The Dark Arcmes ( $X$. polyoilon, Stephens) appears the erd 
of June and heginning of July, Wings one inch five-sixths to two inches one sixth; first pair pale yellowish brown, varied with black and pale clouds, witl a whitish wavel streak towards the hinder edge; sccond pair nshy brown, with a dark marginal border and a pole streak towards the posterior angle, Caterpillar dull white, sprinkled with black spots, with a black hend; feeds at the roots of grass. Very common. Cheshire, near London.

Tив LIvиг (X, rureu, Strpnavs) appears in June or begin. ning of July. Winges one inch one half to two-thitds; first. pair varied with grcy and brown, with a spot on the upper edre, a line from the base to the inner marein, and an irregular streak on the margin itsedf, all browsish Erey; second pair hrown, with a dark marginal streak. Cuterpillmr feeds on the primrose, \&e. Ilertford, Darenth Wood, Netley, Eppinf, \&c.

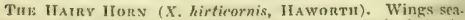
green, with a shortish band and an interrupted terminal streak; the antenne decply fringed. Perhaps a variety of $X$. rurea. Rare. Kent.

THk Clound Bruntw (X. epomidion STEPHTNS) appears in June. Wings one inch one-third to onc-half; first pair varied with grey and hrown, with three pale waved indistinct streaks, the anterior stigma with a black borkler; the hinder markin spotted with brown; second pair ns in X. ruren. Searec. Der. byshire, Yorkshire, Devonshire, Surrey, and Somersetshire.

Tui Fox Ttix, ( $X$. rombusta, Steputiss) appears in June. Wings one inch two-thirds to three-fourths; first pnir dusky brow'n; the ordinary stigmata in the midclle indistinct, with whitish margins, the anterior oval and turned outwards, the external one car-shaped, with an interrupted white margin, and representing the fieure 3 or 5 ; second pair browa, with ycllow. ish fringe, Rare, Kent and Surrey.

The SNIPF (X. scolopacina, IIxworti) appears in June. Wings one inch one-fourth to one-third; first pair varied with grey and brown, with a brownish band at the hinder edge, and a blark waved streak behind the mirldle; the posterior stigna is white, the body slender. Rare. Yorkshire and Surey.

TrE SAXon (X, rectiliner, Stephens). Wings one inch onehalf: first pair ashy grey, with a broad band in the middle, and hinder margin dusky brown; second pair dusky, witls palc fringe. lare. Lancashire.

IEADENA, (SCIRANE).

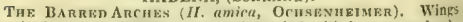
one inch cleven-twelfths; first pair varied with brown and ash, with a broad anfular dusky band, in which the orclinary stigmata are very indistinct, the external one being large, whitisli, and ear-shaped; second pair pale dusky, with a darker central spot and margin, Rare, 
THe Dark Brocane ( $H$. adresta, Ocurseninimer). Wings one inch two-thirch to five-sixths; first pair varied with brown and ashy, with a black line, yellowish streaks and stimmata ; second pair whitish, with the nervures and external margin dusky. Rare. Kent, and Surrey.

The Ponrivar ( $I T$. saturn, Ochsenugimfr) ajpears the end of May. Wines one inch two-thirds to five-sixths; first pair blackish brown, with a black line, having the stigmatiand band paler, and edfed with black ; scrond pair dusky, with the mar. gin, nervures, and a central ereseent darker. Rare. Surrey.

Tие Gotuc 13rocade ( $I$. remissa, SrapHeNs) appears in June. Wings one incl one-half to two-thirds; first pair pale dusky, clouted with two black lines at the base, and a very broad central arch; sccond pair dusky. Rather rare. Yorkshire, Salop, Hertfordshire, Kent, and Surrey.

THe Brown PInionied Brocamiz (II. oblongra, Sremiens). Wings one inch one-half to two-thirds; first pair ashy, clouded witi a larpe wedred-shaped dusky spot behind, and another oblong in the middle towards the inner edlye, towards the posterior margin a whitish streak, which is very much wavel ; seeond nair whitish, with a dusky border. Not common, Yorkshire, Bssex, Kent, and Surrey.

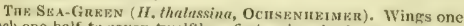
inch one-half to seven-twelftis; first pair ashy brown, clotuled with three white streaks, pale at the base, with a black line; second pair dusky. Not common. Yorkshire, Suffolk, Nolfolk, Essex, Shropshire, and Devonshire.

Tuk Сотие (II. Genista, Ocusaninimer) appears in June. Wings one inch seven-twelftlis to two-thirds; first pair silverywhite clouded with a black line at the base, and nnother resembling the letter I, in the centre; sccond pair whitish, with a darker border. Rather uncommon. Devonshire, Kent, aud Hertfordshire.

Tue Pretty Jrocane (II. contigu, Ochshnuezmer) appears in June. Wings one inch one-lialf to seren-twelsths; frst pair clouded, varied with dusky yellow and white, a white spot on the upper celge at the base, and another towards the inner markin; the linder part of the wing is pale or ashy, with a white waved streak interiorly edeed with arroxy-shaped spots; second pair Whitish, with the nervures and marginal border dusky. Caterpilfer green, with a brown head, and two brown spots on the anterior segment, black stigmata; feeds on ragwort, broom, and otler plants in August or September. Plentiful. Surrey.

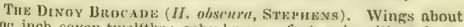
one inch seven twelfths; ashy brown; first pair with a large spot on the upper edge at the base, interually edged with threc black liues, towards the hinder markin a very indistinct waved pale streak. Perhaps a varicty of one of the two preccding.
Very rare.

THE Glaucous Smers ( $H$. glauca, SrepHens) apyears in F 2 
June. Wings one inch one-fourth to one-third; first pair grey. witl the ordinary sjests, funt a waved band, yelinw; seernd pait white, with a whiti-h fringe. ('nterpillter yeltowish and brown, with a ycilow line and black spots on the hack, the sides spotted with white: fecels on the T'ussilapo farfara in August. Scaree. Near London, Deribyshire, and Cifuncestershire.

'I'ZE SHeErs (H. Mrbria, Stermexs) appears in June. Wing, one inch one-fourth to one third; first jair varied with asliy and dunky, with an inslistinct black arch, having three ash-coloured stigmata; sccond pair ashy brown, with a rarker marein. fir. trrpillar dull brown, elouded with red, and withs back lines on the sides and back, the lead black and shining; feeds on daude. lion, Rather ecommon. Warwiekshire, Cheshire, Norfolk, E. sex, Kent, Suftolk, and Devonshire.

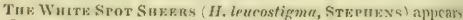
in June. Wines one inch one.fonth to one-\{lirel; ashy white, with an indivtinct arelt composed of yellowish spots, havin three whiti-li stigmata, the lower one divided; difier from thit preceding chictly in colour, being paler. Surcy.

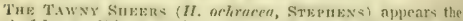

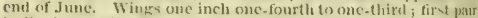
buff colour, with fonr streaks, and the ordinary stigmata pate, haviug the third stigmn wedge-sliaped and blackinh; sccomb phir bricht whitish yellow, with a brown lorker and a yellow fringe. Rare. Noriotk, near I,ondon, and suftolk.

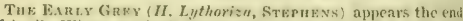
of April. Wings cre inch ous-fourth to one-third; first pair ands. coloured, with an irregular eentral dusky- hand, interrupted by two ordinary car. haped Mipmata ; second pair dusky, with an inter. rupted blackicli streak on the marsin, the fringe rosy. Not scarce. Cheshire, and near London.

Tur C.smpiox (H. ("umbuli, O(ms of Jume. Winges she inch one-third to five-twelthis; first pair sariegated with ashy and brown, the stigmata indented at the base, and diverent, havimg ycllow borders, and disposed be twetn two doulile stroahs of a briplit volet lue; seconil pail rlusky, with a tinge of yellow, aud darker at the hinder mareit

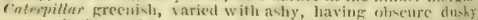

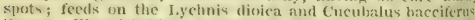
searce. Warwiekshire, Derbyshire, Bedfordshire, Ciloucester. shire, and Kent.

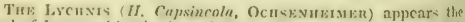
crad of June and berinning of July. Wings one inch one-fourth to one-third ; first pair saresented with aslo colour and brown, with three indi-tinct whitish streaks, the st igmata distinct, margined by a white line; second pair dusky ash, with the margin and a - lender central crescout ducky. ('ulerpillar gremisli, with blackivh spots, laviug streaks on the sides, and a whitish lime undermeath; the head glossy brown; feeds on the Lychnis dioican, Common. Near London, Devonshire, South Wales, and Norfolk. 
Tuz SoAp Wort (II. Saponaria, Ocusunfamer) appears the middle of July. Wings one half-inch to two-thirds; first pair dusky brown, with the nervures and streaks brownish white; second pair whitish, with a very distinet brown margin. C'nterinllur greenish, with darker shides; the liead and first segment hrownsh; feeds on the sizponaria oflieindis aud other plants. Rare. Norfolk, Kent, Suffulk, and Devonshire.

\section{HELIOPIIOHUS (BOISDUVAL.)}

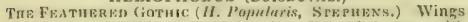
one inch seven-twelttis to three-fourtlis; first pair brown, with the nervures whitish, havine two double streaks in the middle, and anotlier towards the hinder margin, with three-cornered spots; second pair whitish, with a broal dusky markin. Common. Salop, llertiordshire, Kent, Devonshire, and Cornwall.

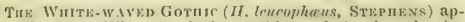
pears in July. Wings ome incls twn-thirds ; first pair ruther intented, rariegated with krey, white, and brown; sccond pair ashy white, with a dark brown central spest in slantiug streaks, aud a fait clusky marginal border. Rare. Sumersetslire.

\section{MAMESTRA (OCHSENHEIMER.)}

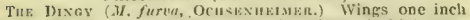
five tweliths to seven-twelfths; first pair variegated with brown, ashy, and yellow, with a whiti-h kidney-sliaped spot, and marfinnl streak; second pair ashy brown, with the nervures, a central cresecnt, and the hinder markin dusky. Not common. lorkshice, near London, Kent, and Suffolk.

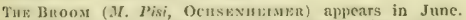
Wings half an inch to two-thirds; first pair reddish, clouded with grey, lovine towards the hioder margin a white wayy streak, tilating at the posteriur angle into a large spot-like jatch; the second pair in the male are whitish, with a dusky marcin; in the female arh colour at the base. Cintervillar pale browuish red, with yellow stripes; fecds on papilionaccous plant in autumn. Rather commun, Dublin, Durtam, Derbyshire, Essex, Middlesex, and Surrey.

TuE Suivixo (Mf. splendeas, Ochazvmermen) apuears in Jnly. Wings one imeh five-twelfths; first pair reddiah brown, with three lanting darker streaks, the onter one terminated with white; the stimmata pale redilish ahth. Second pair buf ach, with themargin, an interrupted trativerse streak, a central crescent, and nervures dusky. Rare. Cumberland.

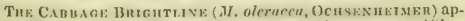
pears the cnd of May. Wiags one inch onc-latif to seven-twelfths; first pair chestnut red, with a yellowisls kidney-shaped spot, and $n$ whitestreak at the hinter margin; second pair whitish, with a dusky margin. Cuteryillus livid, with a dusky line on the 
bnck, and a whitish one on the sides; feeds on cablinge, ictuce, \&e., in autumn. Common, Dublin, Salop, Cheslire, near Lohdon, and Devonshire.

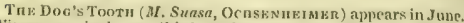
Wings one inch one-thirs to five-twelftlis; fir-t pair browsi, somewliat clouded, with an interrupted black line at the base; and towards the binder maxpin a white streak, with black arrowshaped dashes on the anterion edge. The fringe and second pair dusky. Ciuterpillur green, with reddish and bluish suots, and three hlue streaks; feeds ujon cabbage, dock, lettuce, plantain, kc. Rare. Norfolk, near London.

'Tun Munatro) M, nigrieuns, Strinens) appears the end of Iune. W'ings one inch two thircls; first pair dusky browu, tinged with orange, with the ortinary stigmata and streahs inaler; second pair bufi white, with the hinder margin and ncr. vures dusky. Rare, Kent, Hampshire.

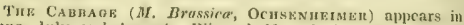
Jure, July, and Angust. Wings half an inch to two thirds; ashy brown, First pair with a white kidney-shaped stigna and streak towards the hinder margin. The colours in the fertale are darher. C'aterpillar green or brown, with white stigmata, und an obscure lise on the back; feeds upon enbliage in autumn. Too common. Yorkshire, Salop, Wiltshire, and Deronshire.

The Wuth-LINe Br.Ack (MI, albidilinen, Stephens) similaz to the preceling. The first pair of wings blackish, witis a white. ish and deeply toothed strenk towards the hinder margin. Pro. bably a variefy of $M$. Brassice. Rare.

TH: WHTE Couon (M. albicolon, Ocusennמmen) appears in August. Wings one inch two-thirds to three-fourths, first pair grey ish brown, with a white kidney-shaped patch, and two sperts, and a scries of yellowish spots towards the hinder mar. gin. lare. Cumberland.

Tue Stranger (M. Alienn, Ocusenumagre), Wings one inch five-tweliths to me-lialf; first pair clouded with brown and ash colour, with a white tuothet streak at the binder ma:gin. The corsclet with a forked crest.

The Nutake (M. Chenopodii, Ocusenufruve) appears in June. Wings one inch one-third to one-half; first pair ashy brown, spotted with black, with thrce stigmata, one of which is hidney-shaped and blackish, and towards the hinder margin $n$ white toothed streak. Caterpillor green, with an obscure line on the back, and a redish one on the sides; feeds on various pot herbs. Common. Near London.

Tue Dot Motu (M. Persicaria, Ochsknulimen) aypears in Jume. Wing one inch one-half to two-thirds; first pair black, variously clouded, with a snow-white kidncy-slraped stigma, laving an obtuse brown crescent. Caterpillar smooth, freen, with a white line on the back, having a fuint cloud on the lourth 
and fifth sefments, witl the tail conical : feeds on the hop, elder, \&.c. in autumn. I'upn brown. Searce. Salop, IIertfordshire, Warwickshire, Essex, and Surrey.

\section{EUPLEXIA (STRPHENS),}

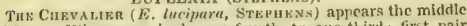
of June. Wiggs one inch one-fourth to onc-third; first pair brownish grey, with a few black spots at the base, a band in the centre, and hinder margin brown; the posterior stigma is kidney-shajed and yellowish. Caterpillar, prass green, with a brown head, legs redilish; feeds on tramble, dock, lettuce, tee. ill nutumn. Not common. Essex, Kent, Surrey, Hampehire, and Devonshire.

IIAMA (STEPHRNS).

TIE Rustic SHovulin KNot ( $\boldsymbol{H}$. bhillimen, Sreprans) appears the beginning of June. Wings one inch five twelfths to seven twelftis, deficxed, greyish brown, waved, with a black line at the base; second pair with the linder margin, nervures, and ccutral spot darker. Cinlerpiltur liglit prey, with a broad white line on the back, and a pale one on the sides; feeds on grasses in autumn. Rather searee. Ncar London, Essex, and Devonshire.

TuE TAWNy X. (II, testacea, STEPttkNs) appears in autumn. Wings one inch onc-fourth to seven-twelfths; first pair brick red with an oblong black malk in the centre, resembling the letter $\mathrm{X}$, and an arched streak composed of black crescents behiud the middle; second pair white, with a somewhat intermipied brown streak at the margin. Iather scarce. Lissex and Devorshire.

THE LINK (II. connexa, Strmmens). Wings one inch onethird ; first pair arliy whitc, witl a black line at the base, a brown band in the centre, separating into two branches, and foined by an obscure dusky streak; second pair ashy, with the margins darker. Rare. Locality unknown.

\section{APAMEA (OCHSKNHRIMER).}

The Crescrent (A. fibrosu, Ocusanihimete) appears the middle of July. Wings one incls one-third to two-tlirels; first pair eliestuut red, with a large darker anfular band-like spot in the entre, in which is a white crescent, the anterior stiema kidney-sliajed and whitish, the streak at the hinder margin paler; scennd pair dusky. ("aterpiller" whitish, membranous, with the bnek dull lrownish red, and the head brown; feels on the Iris pscudacorns. Local. Cambridgeshite.

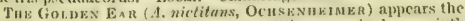
end of July or beginuing of Amgust. Wings one incli one-sixtiu to one-third; first pair reddikh brown, tinted with fold, streaked with hrown, with the posterior stigmin large, ear-slinjed, and of a whitish gold colour. Rare. Kent, IIauts, Devonshire, and Isle of Arran. 
THe Rustic Mourner (A, didyme, Ochseniteruter) nppears in August. Wings one inch one-fourth to one-third; first pair black, slightly clouded, and kidney-shajed, with stigma suow. White; second pair dusky, paicr at the base. Rather scarce. Near London, Kent, and Midrilesex.

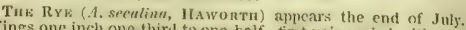
Wings one inch one-thiril to one-half; first pair varicd witlo erey and brown, with two streaks paler, and whitish stigmata. Kare. Kent and Surrey.

THE Warmony (A. wnunimis, Ochezuzrmen). No distinefive description of this insect has yet been published to my knowledge. Very rare. Scotland.

TuE Puanf: (A. arwlen, StrinENa) appears in August. Wings one inch one-sixth to five-twoffths. First pair ashy brown or grey, clouded indistinctly, streaked with a kidney. formeri stigma, now white, Plentiful. Sliropshire, near London, Essex, and Devonslire.

THE Latren I (A. I-Nige, STERHENs) appears the beginning of Atrgust. Wings one inch one-fourth to one-tlied. Fir pair saried with Grey and brown, with the letter $I$ in the centre. Plentiful. Near Londou, Surophire, Ensex.

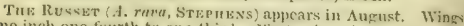
one inch one-fourth to one-llirel. Iirst pair pale reid, with the upper and hinder mareins irregulatly hrown. Not scarce. lertfordahire, near Iondon, Surrey, and sliropslire.

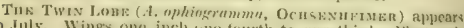
in July. Wiages one incls ene-fourth to me-thirc. First pair grey, with a romdish larese black patels in the mirlule of the upper edge, and margind teswards the inner edge; a black spent-shaped spot at the posterior anfle, and another smalles one near the hinder marein. Rare. Lissex, Middlesex, Keut, and Surrey.

\section{MIANA (STEPheng).}

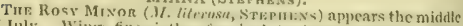
of July. Wing five-sixtlis of an inch to cleven-twelftls, First pair glaucons, with a waving rose-coloured streak at the hinfer marein, and blate marks resembling letters in the centre. Kare. Essex, Kent.

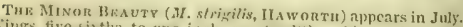
Winge five-sistlis to one incli one-twelth. Jirst pair varied with ashy and grey, clonded with three white streaks, posteriorly connected hy a black liue. Cuterpillno thalyg white, with a vio. let line on the back, and $t$ wo on the sides haviug hlack stig. mata; head ycllowish lowwn. Rather searee. Derloyshire, Norfolk, Suffolk, (iloncentershire, Hamphlire, and Jevonshire.

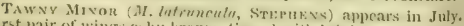
First pair of wiugs flyy brown, tinged with bright eopper, hav. ing the sti gmata and streahs paker. Not common. Cambridge-
shire. 


\section{CONSPECTUS OF MOTIY.}

TuE Br.ACK. woon ( $M$. Whiops, Stwrixss) appears the endof june. Wings eleven-twelfths to one inch, black; the first pair with deeper clouds, the hinder margin faintly tinged with a coppery hue. Rather common.

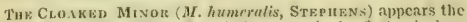
middle of Auzust. Wings five-sixtlis to one fnch; first pair deep brown or black from the base to the middle, then whitish ash, with a pale waved streak towards the hinder margin irregularly clouded with brown, haviner the antewnt brown. Not scaree. Cambridgeshire, ilertfordshire, kent, and Surrey.

Tuz Frounced Minon (H. terminatis, STEPHExs) appoars the middle of August. Wings five-sixths twone inch one-twelfth, reditish brown, with the linder marein waved witl blackish; the antemmer rust brown. Not so plentiful as the preceding. Essex, Niddlesex, Kent, and Surrey.

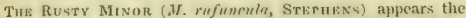
midtle of August. Wings fire-siaths to one incli, all red brown, with three sireaks, which are jale and very indistinct; nn the hinder margin of the fir at pair is a row of black triangular cresceut-slinjed spots. Scirce. Norfolk and Suffolk.

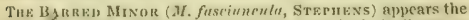
middle of Aurust. Wings three-fourths to one inch, buff grey or rell ; first pair with a broad band of a darker sliade in the centre, interrupted by the ordinary stimmata, whichare paler. Rather scarce, Hertfordshire and Middlesex.

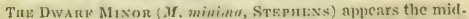
dile of August. Wings two-thires of nu inch, ashy red; first pair with two syots and the liwee ordimary streaks of a paler lue : second pair with a white fringe. Very searce. Cambridgeshire and Kent.

\section{CELIENA (STRPHENB).}

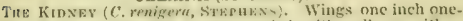
third; first pair arcenish brown, varied with yellosw, with a tarker band in the middle, in which the ordinary stigmata are placed; second pair wlitish, with a brown border. Lare. Near London.

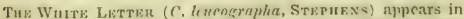
Jaly. Wings one inch one-siath to one-third; first pair rosy brown, with two black lines at the base, a yellowish wavel streak towarts the postoriur margin, and the ordinary stigmata huff colonr ; seeond pair with the margin and contral syot darker. Local, Cambridgeshire.

Tuk Laxep (C. Lanera, STupmevs). Wings deven-twelfths to one inch ; first pair of a conpery brown, wilh four paler very indistinet streaks, the tirst at the base, the second before, and the third behind, the middle and the fourth indented, but slightly curved at the hinder margin; second pair yellowish axh, with a brown border. Lare. Nurtolk, and Cambrittreshire. 
Tü IIBEnNIAN (C. Hibernira, Steprexs). Wings nne inch onc-fourth; first pair reddikh brown, with a band towards the linder markin, and an indented streak paler, liaviug the first stigma indistinet ; second pair with the central creseent and mar. gin darker. Local. Near Dublin.

\section{SCOTOPHILA (STEPHINS).}

Tur Pormyay (S. perphyrea, STEPHess) appears the end of July. Wings five-sixths to one inch one-sixth; first pair dusky red, with a purylish tinge, with several white streaks and spots, margincel with black; sccond pair ash grey, with a black marginal streak. Caterpillur feeds on various kinds of lieath. Scarce. Yorkshire, licnt, and Hampshire.

\section{ACIIATIA (IIUBNER).}

TuE PINe (A. mimiperda, STEPHENs) appears in March. Wings ome inch one-third to one-half; first pair varied with rush brown and yellow, with the ordinary stigmata conflucnt; sccond pair brown, with a rosy tint. Caterpillas bright green, with a white line on the back and two on each side; fecds on the pinus sylvestris and other firs in Jume. Not scarce. Yorkshire, Derbyshire, Norfolk, and Iertfordshire.

\section{ACTEI3IA, (SтарHкNS).}

The Porthand (A. precox, STRPHENS) appears in June and September. Wings one inch scven-twelfths to two-thiris ; first yair translucent ashy green, with a bruad wayed red streak to. wards the posterior margin; sceond pair 'dusky $a+h$, with a white fringe, (aterpillar grey, with a plale line on the back; feeds on the Sonchus olcraceus, Viola tricolor, and other plants in sandy jlaces on the coast. Not scarce. North of England, Portland Island, and Devonshire.

\section{TRACIIEA (OCHSENIIEIMRR).}

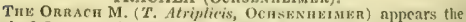
cnd of June and in september. Wings one inch two thirds to five-sixths; first pair somewhat ashy frey, clouded with yclow or greed, having a large whitish spot in the contre; second par dusky, with a diarker border. Cuteryillar reddish, spotted with white, with a brown line on the back; feeds on dock, Atriplex, Polygonum bydropiper, \&c. Scarce. Cambridgeslire, near London, and Gloucestershire.

\section{VALERIA (GERMAR).}

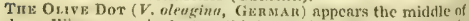
Juls. Wings one inch two-thirds to tive-sixths; first pair marbled with freen and brown, with five white spots on the upper edge towards the tip; the anterior stigma brown, with a 
white border, the outer one large, ear-shaped, and white; second pair pale, with a brown margin. Cuterpillur ash grey, with black spots and reddish and black indented streaks bchind, having the collar red; feels on the black thorn. Very rare. Surrey and Gloucestershire.

\section{MISELIA (OCHSBNHEIMER).}

TuF ITAJiAN TWIN ( $M$. bimaculost, Ocuskniteinter) appears in July. Wings two inches, ashy white; first pair slightly clouded; sccond pair with two spots, one large and brown, placed at the posterior angle, the other crescent-like in the centre. ('aterpillar, grey, with dusky and whtish lines, each segment with an oblomg black spot, in whicl the stigmata are situated, having a large brown patch towards the head; feeds on the elm. Rare. Gloucestershire.

THE Irawtuok ( $\boldsymbol{H}$. O,yncunthe, Ochsexherame) appears the end of September. Wings one inch seven-twelfths to two thirds; first pair varied with brown, green, and pale, with a white crescent on the inner edge; second pair dusky, with the margin darker, on which there is a shortish white streak. Cater.. gillar, brown, varier with black and white, with a bump behind; feeds on the white and black thorn in Jume. Not scarce. Warwickshire and Cheshire.

Tпв Aрпі, ( $M$. Apritina, Ocnswnetmer) appears the middle of April and in ()etober. Wiags one inch seven-twelfths to twothirds; first pair bright green, with a streak of ariow-shaped spots near the hinder fedge, and another streak composed of smaller spots on the margin itself; second pair deep brown, with a white streak at the hinder edre, and a shortisit one at the posterior angle, the fringe white, spotted with brown. Caterpilla", variable, ash coloured, with dark spots and lines on the back and siles, or with whitish spots on the back, and whitish lines on the sides; feeds om the oak, beech, apple, \&c. Common. Yorkshire, Essex, IIevefordshire, Kent, Surrey, and Somersetshire.

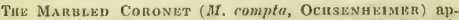
pears in Jume. Wings one inch oue-third to onc-half; first pair brown, varied with black, with a broad hlack patch resembling the letter $\mathrm{N}$, in the niddle towards the upper edge, mi a white waved or indented streals near the hioder edge, expandiug into a small spot at the tip; sccond pair dusky, paler at the base. Cuterpillar grey, with brownish spots on the back; fceds on the Lychuis dioica. Not common. Kent aud Sussex,

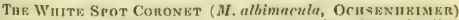
appears in June. Wings one inch the-twelfths; first pair olive brown, waved with black and white, with the anterior sticma and a square-shaped spot near it white, having the fringe white, spotted with black; second pair ycllowish brown, with a tusky border, and two whitish spots towards the inner angle. Very rare. Kent. 
POLIA (IUBNER.)

THE Survixg Bnow ( $\boldsymbol{l}^{2}$, adrena, $($ (U) end of June. Wings one inch five-sixtlis to two inclues; first pair asliy brown, with three indistinct pale streaks, and towards the hinder edge a streak of confluent angular spots; second pair dusky, with an obscure markinal line, having pectinated hairy anterna. C'atcrpiller fecds on the Lcontodon taraxacum, and Iactuca sativa. Not scarce. Near London, Norfolk, Sufiolk, and Devonshire.

Tuk TAwny Sulve ( $\boldsymbol{l}^{2}$, nitens, CurTIs.) Wings one inch five-sixtlis; first pair brown, with a silvery tinge posterierly, the kidney-shaped stigma semicireled at the lower extremity with pure white, towards the hinder edge a streak of contluent angular spots, but whiter without, having the antenna setaceous and naked. liare. Norfolk, and near London.

Tue Grey Arcues ( $I^{3}$, bimuculosu, Strarnexs) apperars the end of June. Wings one inch five-sixtlus to two inches one-sixth; firt pair whitish, clouded with brown, black, and rery faint ycllow. ish, the stipmata larke, white, and more or less ash grey in the contre, near the linder edige an indented black struak, and a marginal row of dusky spots. Crsterpillor lirown, with a waved pale reddiah streak on the sides, and two pale lines; feeds on the Verbascum tlapsus, Not rare. Cumberland, Cheslsire, Essex, Kent, and Surrey.

THE (iRHAT Brocane ( $P$, nemltu, Ocmsexmlimen) appear in July. Wings two incles one sixtla; first pair clouched with white and brown, with three white streaks, second pair much shorter, ash grey undemeath, with a blacki-is central erescent, and the hinder margin white. ('ulergillm) black on the back, the sides brown, with buft-culonred lines; fects on the dandelion and lettuce. Scarce. Cheshire, Essex, and lient.

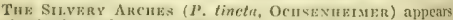
the beginning of June. Wings one inch five-sixtlis to two inches. First pair clouded, silvery asl, with varions waved streaks, the outer one beine connected with tlwee black spots Caterpillar frey, with five black atripes on the back, and palc whitish ones on the sides; the latter having a reddich waved streak above them; feeds on restharrow, ke. Very rare. Kent, and Surrey.

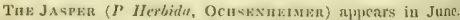
Wrugs one inch five sixtles to two juches. First pair pale ye! lowish abh, with indented black streaks; towards the hinder chese a pale and very indistiuct streak, with two or three black triangular spots towards the upjer edige; flie orilinary stigmati larke, and bordered with black. Second pair lowwninh yellow, with a browt narsin, the fringe faint yellow. Catromillos freen, with black spots on the back, the stigmata white, and head brown; feeds on the Cochlearia armoracia. Scarce. Lan. arkshire, Norfolk, and Kent.

The Tesple (P, Templi, Ocnsennkmar, ) appears in October. 
Wings one inch three fourtle; first pair obscure frecnisls ach, with waved streaks, and llic ordinary stimmata yellowish, the fringe ereenish ash, with dusky spots; second pair yellowish Anb, witb a dosky streak belind the mistdle, and an indietinet one townrels the hiucler matgin, the friuge ash colour. Lare. Laucashire, Warwickslire, and Devonshire.

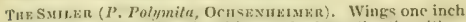
three fourtlis; first pair ash white at the base, the tip with a frecnish brown band in the centre, in which the ordinary stigruata are placed; second pair slusky, with an obscure crenated streak behind the middle, and a whitish cloud at the inner angle, the fringe whitish. liare.

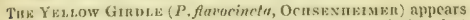
the end of June. Wing's ane inch two-thirds to fve-sixtlis ; first pair lnary, varied with ash brown, and orange colour, having a faint streak of triangular brownish spots externally celged with yellow at the hisder margin; sccond yair whitisli, with a brown crenated streak behind the middle, and an ash colourcd marginal horder. ('steryillor preen, with a pale line on the back and sides; jeels on the dock, currant, Romeberty, lettuce, willow, \&e. Not common. Yorkshire, Essex, and Hertfordshire.

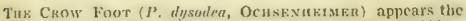
miditle of July. Wings one inch one-third to five twelfths; first pair anh coloumed, with orange yollow spots, \& blackish laud in the exufre, and two streahs of crescent-shaped spots, the frimger avly and tawny ; second pair ashy frey, with adukky

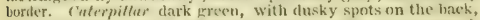
and a yellowish line on the sides: feeds on lettuce, wormwood, se. Not-carce, Essex, Hertfordshire, Keut, and sizrey.

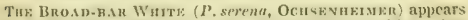
the emi of Junc. Winges one inch one-sixth to one-third ; first fnir Ashy white, witli a broad dusky band in the middle, boumbed on each side by whiti-l, streaks, the stigmata ash coloured with white margins, havine the fringe pale an grey, spotted with white; second pair as 12 grey, with a contral sjot and margin dusky, the fringe white, fintmpillur fecis on the Hieracium unbcliatum, l.contorlon isispidum, Sonchus palustris, \&c. Not scarce, Kent.

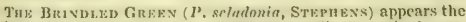
middle of April aud middle of October. Wings one inch onethird to one-half; fint pair varicd witls green and ash, with indistinet black streaks, scattered black clouds, and near the hinder edge a pale streak of irregular black triangular spots, and a marginal row of more regular black triangular spots ; sccond pair ash grey, with a lorown border, in which is a whitish streak. Caterpillu dirty green, with varians dusky and pale stripes and dusky elourls; feeds on the oak. Not scaree. Shropshire, Essex, Hertfordslire, Kent, and Surrey.

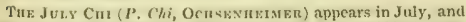
frequents barren districts. Wings one inch five-twelfths to one- 
half; first pair variously clouted with ash, brown, and black, the ordinary stigmata white, between wlich and the inner mar. gin is a black mark like the Greek letter $\chi(c h i)$; secona pair of the male white, with nervures and margin dusky, of the fomale dusky, with a dark margin. Caterpillar grecn, with two white lines on the sides; fecdson the Aquilegia vulgaris, Sonchus olera. ceus, and S. arvensis, Arctium lappa, Lactuca sativa, \&c. Not searce. Cumberland, Yorkslire, Derbyshire, Wales, Durham, and Wiltshire.

\section{APATELA (Ḧ̈B̈NRR),}

Tre MrLter (A. Leporim, II IiвNkR) appears the middle of May and Augrst. Wings one inch five-twelftis to two-thiris: first pair white, with spots and small waving lines black ; second pair snow white, glossy, and without spots, the nervures sometimes slightly dusky. Ciutrpiltur with yellowish white hairs, fud several black tufts on the bnek; fueds on the alder, willow, poplar, birch, elm, Re., in the autumn. Rare. Kent and Surrey.

THe IIARE (A. Brudyporinn, Stipnise) aplears the beginning of June. Wings one inch five-twelfths to one-half; first pair whitish, sprinkled with minute black spots and lines, the hinder margin strongly spotted with black; second pair white, with a row of black sjots on the hinder margin. Caterpillew grass grcen, clothed with long white hairs; feeds on the Prarius domestica. Rare. Kent and Surrey.

THE Sreamone Tussoek (A. Aceris, StepHzNs) appears the end of June. Wings one inch one half to two-thircs ; first pair ashy white, with waved black lines, and the anterior stigma formed by a black ring; sceond pair whitish, with dusky ner. vures. Caterpillur covered with long yellow hairs, liaving flse red and yellow tufts on the back, and $n$ row of white chain-like spots edred with blark; feeds on the horse chestuut, maple, oak, ash, \&c., in the autumn. Not scarce. Cambridgeshire and Essex,

\section{ACRONYCTA (OCHSENHEIMER).}

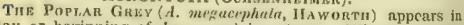
May or beginning of June, and in autumn. Wings one incli seven-twelfths to two-thirds; first pair ash grey, waved with black, with a whitish arch trwards the hinder marcin, thic anterior stigma ashy, with a black ring; seconil jair white, with the nervures and margin dusky, the fringe wijite, with dusky spots. Caterpillur, with a large hent, hairy, brown, spotted with rusty red, having a primrose yellow spot on the hinder segment; feeds on the poplar and on willows. Not scarce. Ifertfordshire, Canl. bridgeshire, and Kent.

TuF Cononet ( $A$. Ligustri, OCHSEymerimer) appears the end of June. Wings one inch five-twelfins to one-lialf; first pair varied with brown and greenish, slightly waved with black, the anterior stigna round, brownish, with a white markin, having a large white coronet-shaped spot uear the hinder margin, towndls 
the upper edge; sccond pair brown. Caterpillar pale ycliowish freen, with ycllowish white stripes and slender black hairs; feeds on the privet (Lignstmun vulurare.) Rather searec. Derbyshire, Essex, Kent, Surrey and Suftolk.

TாF Almer (A. Alni, Ocusenisimer) appears the beginning of June. Wings one inch one-half to seven-twelfths; first pair brownish black, with a large ash-coloured patch at the base and tip, two very deep black lines, one at the base, and the other near the hinder edge towards the posterior angle, which is ash grey ; sccond pair whitisl , the fringe of all the wings intcrupted with dusky. C'uterpillur black, with yollow spots and long hairs on the back; fecis on alder, ash, willow, birch, poplar, \&c. Rare. Norfolk, IItatingitonshire, Warwickshire, Uorsetshire, Devonshire, and Hampshire,

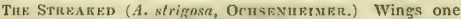
inch one-fourth (?) first pair whitish grey, mixed with dusky lrown, with three black lines before the inner cdge; second pair preyish ash, with a transverse streak beyomel the middle, and a narrow marginal line. Caterpillur yellowish freen, with an irregular broad yellowish brown line on the lack, sprinkled with black, head reddish; fecds on the black thorn and mountain ash. Rare, Norfolk.

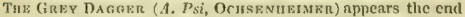
of June, and frequents poles, walls, and trunks of trees. Wings one inch one-half to seven-twelftis ; first pair ashy brown, having a faint black $\psi$ towards the tip, and a strong one towards the postcrior angle; second pair dusky, with a darker margin. Cuterpillar black, with a broad ycllow line on the back, and transverse red streaks on the sides; the fifth segment with a lonpish btack conical protuberance; feeds on the lime, alder, poplar, \&c. Very plentiful. Durham, Yorkshire, Essex, and Deronshire.

Tay Dank Dioger (A. tridens, Octranmemane) appears in June, and frequents woods and woody places. Wings one inch one half to two thirds; first jair ashy white, having a faint black $\psi$ near the tip, and a stronger one towards the poste. rior ancle; second pair whitisl, with a pale ashy maryin, and a faint transverse rhsky streaks behind the middle. ('aterpillar black, with a narrow yellow line on the back, and a red one on the sides, the fifth segment spotted with white, having a conical protaberance on the back; fecds on the plum free, sloe, willow, white thorn, \&c. Not uncommon. Essex, near Loudon.

Tre Sprar Point (A. muspis, Ochsenugister) very similar to the preceding. Wings one incli to one incl two thirds ; first pair greyikh white, with a yellow tinge, a waved black streak towards the hinder edse, in which are two $\psi$-like marks, the fringe whitish ash, spotted with black; second pair whitish, with a dusky central creseent, a trausverse streak lychind the midelle and posterior border. Rare. Kent.

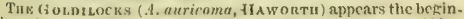
ning of Jaue, Wings one inch five-twelfths to seven-twelfths; 
first pair whitish ach, with the orlinary stigmata distinct and black, and towards the hinder edge an imented black lire termi. natiug at the josterion angle in a patch resmbling the $\psi$. like character. ('ateryillar black, with a reddish yellow spot on cach segment, and orange legs, hatirs yellowish red; fechls on bireli, aspen, heath, bramble, wortleberry, \&c., in autumn, Local. Surrey,

Thr Lrent KNot-ensse (A. similis, CurTas). Found with the preceding, of which it is probably a small varicty. Wings one inch five-twelftis, ash. prey; first pair with a sorncwhat waved black strcak betore the middle, an olblicfue shortinh dusky one in the midelle, and a thirit somewhat like a necklace, and white, towards the hinder margin an indented black streak, with a faint $\psi$ at the postcrior angle. Not rare. Surrey.

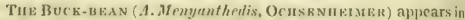
June. Wiugs one inch one-half to seven-twelfths; first pais whitish ash, cloucled with brown, with the orelinary spots black, and towards the hinder edre a waved black indented streik, bearing the t mark near the posterior angle, the anterior stigma is small, and formed by a blacls roms; second pair aslay krey, with a central spot amel marein (lusky. C"uleryillor black, with a lrownish red stripe on the sides above the lefs; feeds on the Menyanthes trifoliata. Not staree. Yorkshire.

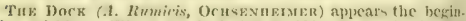
nine of May. Winss one incle five-twelfthe to one-half ; firt pair saricd with aslıy and lrown, with black waved streaksand a whitish patch at the imer edec; second pair $n \mathrm{~s} / \mathrm{krey}$, witha dusky margin. ('ulerpillar dusky, spotted with wlite and red, with a ycllow line on the sicles; fects on the bramble, deset, poplar, \&e., in entums, papn brown. Conmon. Clueslire, Norfolk, Essex, Hampshire, and Devonshire.

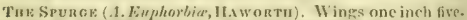
twelftis to one-half, ash grey; first pair waved with brown, the stigmata whitish, behind which is an a-hy streak in form of a necklace. ('ateryilker lipbt. brown, with black spots on the back, and a rusty brown erescent on the neele; feeds on the Euplurbin esula, and E. cyparissias. Kare. Near l.endon, and Hamp-hire:

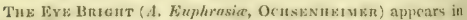
June. Wiags une inch one-lıalf; fir-t pair yolluw a4h, with brown streaks; second pair pale whiti-h ash, with a contral crescent and margin of a deeper shade, dusky in the tomale; abdomen yellow ash. ('nteryiller black, with a series of white spots on the back, and dusky ones on the sites; lessiblack; feeds on the wlite thorn, bramble, Euphrasia oflicinalis, Re. Rare, Near London, aul Kent.

\section{BRYOPIILA (OCHSENHEIAIER).}

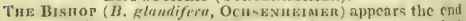
of June. Wings eleven-twelftlss to one inch one-sixth; fint pair bright green, with various large black patches, raore or less 
bordered with black, the uppor edge and fringe, spotted with black; second pair dusky, with a darker marmin and white fringe. ('aterpillar tult yellow, with black spots, and a whitish line on the back; feets on the bichen saxatilis. Not unconmon. Middlesex, and Jampshire.

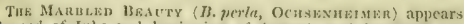
the cond of July and boginning of Auzust, and frepuents sild walls. Wings eleven-twelyths to one inch; first pair whitisli, with black wavect transverse sercaks; the stigmata larke, brown, and hordered with white; second pair aslis white, with the cen-

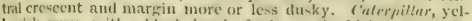
lawish grey, with a black head, fecis on tie Lichen saxatilis. Heatiful. Essex, Kent, and Surrey.

\section{DIPITTILRA (HÜBNER).}

Тнв Sporter ( $\boldsymbol{D}$. ladificu, Тнехтse $1 \mathrm{kE}$ ), Said to be British on doubtful authority.

Tuz ReNic (I), runiom, Octsenterm:n) appears the beriu. nis.g of June. Wimgs one inch one-third to five-twelfuls, first Inir very bright freen, with mumerous black spots bordered with white, ant a markinal series of triangular black spots; sccond pair nearly black, with small white spots at the posterior angle-fringe white with brown spests. Cotergilles, dushy, with large tawny and minnte white spois on the back. IRare. Norfolk, Lent, Somersetshire, and Devonshire.

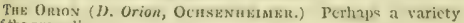
of the preceding.

\section{TIIYATIILA (OCHERNATIMER).}

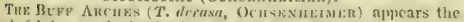
end of July, or the beginning of Angeust. Wings one inch onelalf to two-thirds; first pair without scales, variquated witls white and tawny, in the middle with hrown and whitivh, with two white bands converging pusteriorly ; fecond patir dusky, with a tinge of red. Catiognthe, frrenish yelluw, with dusky hrown spots and back haes, Rather common. Hertiordshire, Essex, Kent, and Devonshire.

TuE PEAcu Brossom ( $\boldsymbol{T}$. butis, Ornsevnramer' appeara the mutale of Jume to the'end of July. Wings une inch five-tweliths to seven-twelfths; first pair olive-brown, with fine palc rome-colnued spots, of which that on the posterior angle in the largest, with n mimute one adjoining it; sccond pair dusky, with a pale waved streak behind the middie. Calirpillor, rust.larown or dusky, with lnmps on the back, aud a zigzaf streak on the sides; feeds on the bramble. Not rare. Norfolk, Essex, Keut, and Surrey.

\section{ERIOPUS (TREITSCIRE).}

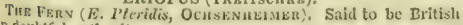
on doubtful authority. 


\section{CALYPTRA (OCHSENHEIMER).}

TuE HenALn ( $C$, Libutrix, OchsENIEIMER) appears in Aprit and end of July. Wings one inch two thirds to five-sixths; first pair grey, clouded with brown, with two snow-white sjuts, and towards the hinder margin is a slanting white streak; second pair dusky, with a darker streak behind the middle. Caterpillnr, green, with reddish stigmata, and a white line on the sides; feeds on the poplar and willow. Not uncommon. Cumberland, Durlam, Yorkshire, Essex, and Ilampshire.

\section{CEROPACIA (STIPHENS).}

Tie SATIN Carpet (C. flueluosa, Steritens) appears the midale of June. Wings one inch one-third to two-thirds; first pair ashy white, with a very broad brown hand in the middle, in which are some dark wayy streaks, and a black creseent in place of the posterior stigma; second pair whitish, with a streak be. hind the middle, and the hinder margin dusky. Caterpillar, yellowish white, with dusky brown head; feeds on the birch. Not common. Kent and Surrey.

THE Twiv Poixt Carpet (C.duplaris, StePIEns) appeans the middle of Junc, and frequents woody places. Wings one inch one-quarter to one-half; first pair ash grey, with a veny broad dusky band in the middie, in which are two black spots: second pair brownish asls, witl a pale obscure streak bejind the midule, and a dusky centrat crescent. ('aterpillur, yellowislt green, with a red line on the back, and small white dots; the heau reddish brown; fceds on the poplar. Not scarce. Kent, Surrey, llampshire, and Devonshire.

Tun Dwarz Lutestring (C. diluto, STrpuens) appears the end of August. Wings one inch ouc-quarter to one-half, fint pair ash-coloured, with two straight rusty-brown indistinct hand, with a brown wavy streak behind them; second pair whitisl, with a band behind the middlc, and hinder margin ashy grey; the frimge whitish. Coterpillur, pale, with a dusky line on the hack, and black head; feeds on the oak. liare. Essex, Kent, and llampshire.

TuE Poplar Lutestrivo (C. Or, Stromins) appears the end of June. Wings one inch one-half to two-thirds; first palf ash colour, with brown waved strcakr, and a central grey spot greatly resembling the letters O R. Cinterpillar, green, with 3 brown head, with the anterior margin black; fecds on poplar. Rare. Essex, Kent, and Devonshire.

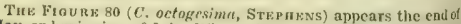
May, or betrinning of July. Wingrs, first pair purplish, with browa waved streaks, and a yellow central patch, nearly repre. senting the figure 80 ; second pair whitish, with an obscure betid - betind the midde, and the hinder margin dusky. Caterpillur. yellow, with black dots on the back, and brown head; feeds on the poplar. Rare. Shropshire, Warwickshire, and Gloucestershire. 
THE YRLLOW-horned (C. Aavieornis, Stepmens) appears the end of February, or beginning of March. Wings one inch onehalf to seven-twelfths; first pair asli-coloured, with three black streaks; second pair brownish-ahh, with the margin and a streak behind the middle dusky, antenne yellow. Cit erpillar, yellowish. green, speckled with hlack, with a pale white lime on the sides, and two large eye-like sjots; head brown; feeds on the birch, jopler, and oak. Rare. Kent and Surrey.

TIK Frostan GRENn ( $C$, ridens, STEPHENS) appears the beginuing or middle of April. Wings one inch five-twelfths to une half; first pair varied with green, brown, and white, with a whitish distiact large spot at the base, and two waved whitish streak, having small white lines and black eresecnts towards the tip; sccond pair white, with the nervures towards the tip, and the hinder markin dusky; antenne yellowish. Caterpillar, yellowish freen, with a wlitish stripe anteriorly on the back, some black dots on the sides; legs brown; head red; feeds on the oak, Rare. Kent and Surrey.

\section{TETIEA, (OCHSENHEIMER),}

Tue Or.rve ( $T$. subtusa, OcusknHzrakt.) Wings one inci one-twelfth to one-quarter; first pair olive-brown; the thrce stigmata olive colour with yellow borders, and four yellowish streaks; second pair dusky, with pale ashy fringe. Caterpillar, whitish green, with pale stripes and small white spots; the head black and forehead white; feeds on the poplar. Scarce. Essex, Kent, and Surrey.

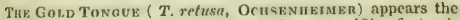
end of July. Wings one inch to one incls one-twelfth; first pair grey brown, with four palcr streaks edged with white; the first and hinder stigmata car-shaped, olive, with a pale border; the third stigma very indistinct, the fringe chestnut brown, sceond yair dusky, with pale reddish fringe. ('aterpiltar, grecn, and very slender, with three white lines on the back, and one on thesides; feeds on the sallow and poplar. Not common. Essex, Kent, Surrey, Hertfordshire, and Devonshire.

The St, ENder Gold Tongue ( $T$. grucilis, Strputens). Wings one inch one-twelfth; clifiers from the preceding. with which it is found, in having a longer and more slender body; the first pair of wings darker, with the strenks less yellowish, the third being straiglit, and the fouth wanting; the stigmata have pale margins, Searce. Essex, Kent, and Surrey.

\section{BOMBVCIA (IIUBNRR).}

THE OSIER (B. Viminulis, STFrHENs) appears in June. Wings oue inch to one-fourth; first pair glossy ashy red, with black clouds; the ordinary stigmate with interrupted black margins, the base with a black line; second pair frey, with a black streak on the margin; fringe of all the wings hairy. Catevillar pale green, with tive whitish stripes; licad brown, with black spots; o 2 
feeds on varions kinds of willow. Not common. Ifertfordshire, Kent, and Surrey.

\section{CYMATOPHORA (TREITSCHER).}

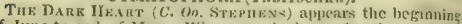
of Junc to end of May. Wings nne inch onc-fourth, to seren. twelftlis; first pair yelinwish, with rust-rerl bands, and slightly waved streaks; the ordinary stigmata yellow, the linder one heart-shaped; second pair white. C'aterpilinr, brownish red, will white spots and liney; heal black; fects on the oak. Not common. Yorkshire, I'ssex, and Kent.

\section{COSMIA (OCHSENTELMER).}

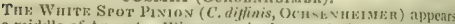
the midhlle of August. Wings one incli one-sivth, to one-third, first pair rouy-brown, with tluree red streaks; three white spost on the mpuer edtee, and a black twin spot at the tip; second put very tusky with a yellow fringe. Catrrpillur, green, with whit stripes; head and fore leg; black; fecols on the eim. Not pheth. tiful. Ilertfordshire, surey, and bevonshire.

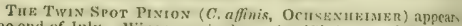
the end of July. Wings one ireh oue-twelfth (o ane-sixth; first pair rusty or grey ish lrown, with two white strealis, and a twis black spot at the tip; second pair black, with a yellowish frimes. Cateryillar, grecusish-white, with greon lines; each serment with a black crescent; feets on the cim. Not searce. Iferuort. shire, and surrey.

Tue Crascrent Pixion (C. Pyralinu, Ortrsextretmen) appears the end of July. Wings one inch me-tourth to five-twelfthe first pair purplisis ret, with stronely wavet streaks, and a white crescent-like patel ois the upper edfec toward the posterior masgin; fringe yellowish red; second pair pale red, with red fringe. Caterpillar, grees, with five white lines, and some white spet, on the back. Rarc. Norfolk, Essex, and lient.

Tut Dunar ( $C$ t) rmetzinu, OCH of July. Wings one incli one-fourth to five-tweliths; first pair grey, ycllowish or rectlish, with darker streahs, a contral blact spot, and the hinder margie spotted with black; second pair red, with the upper edse yellowish, and the fringe red. Cinteryiltur, green or dusky, with ash culoured streaks aut yellowish spats; feeds on oak, lime, liazel, Xe. Common, (ilamorganshire, Shropshire, near Lontion, and Devoushire.

THF ANGLE STRIPE (c.fulrago, OCucENHEIMER) appears the end of July. Wings one incli five-twolftis to two three-fourths first pair plain or tecep ycllow, with a distinct reddish one-nugled streak before the midelle, and a strmewhat waved one behind the midlde; the stigmata paler; the binder margin with a black spot; sccond pair straw colour. Ciaterpillar, dull freen, with a whitish stripe on the hack, and three pale ones on the sides; feeds on the birch. Very rare. Jent. 


\section{XANTHA (HÜвNER).}

Tit: PIVK-BAR ( $X$. fiaviro, Cvitis) appears the beginning of seftember. Wings one incli one-fourth to one-third; first pair osange eoloured, with purplish spots on the upper edec and dise, and a slantimg spotted band of the same tint behind the middie; fringe purplioh; secend pair pale yellow, with nn obseure dusky streak luelind the midtle; fringe ydllow. Cuterpillas, brown, rather cloudad, with dusky, having a romnd licad; feeds on the sallow and plantain. Not searee. Kent, and Surrey.

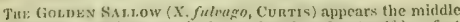
of Septemlicr. Wings one inch one-fourth to five-twelfths; first pair 3 ctlow, clouded with brikht gold, with two very much interrupted reddinh brown spotted baukls; second pair yellowish white with a primrose yellow singe; thorax yollow. Caterpillar, pale, witlk ft brown heal; feeds on the bircli. Very common. Near London.

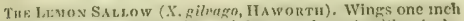
one third to five-twelttlis; first pair lemon colourch, with a dusky spot behind the midelle, and a streak of dusky spots towards the linder matrin; second pair and fringe pure white. Very rare. Essex, Kont, and Surrey.

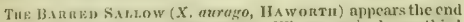
of Aurust or hepinning of Septentser. Wings one inch one-third to five-servenths: tirst frair golden yellow, clouded with red, with two disky purjlish bands; sccond pair whitish, with a posterior stak, marein and finge red. f'utrpiller, grey, with small slantiug red lines; feeds on sallows and willows. Not common. Kent and Surtey.

Tuk Cwarus-Bir ( $X$. rentugo, Cunts). Wings one inch one-thirel to five-twelftis; first pair crenate golden orange, with a browninh one-angled band in the midslle, and the hinder margin of the salse colour; sccond pair pale reditish yellow, darker ut the margin, with two olnewre struaks bchind the middle, fringe brown. Lare, North of England, Norfolk, and Dorset-lire.

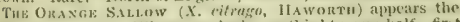
midtle of August. Wings one inch one-tlird to one-lialf; first pir bright oranes yellow, with the streaks nud margins of the stimata brownish red, C'aterpillur, brown, witls a pale streak on the back and sides, and a yellowish lise above the legs, head reddish; fects on the lime. Lather searce. Lisex.

Tuk Funge (X. fimhriago, StepHeve). Wings one inch onethiril; first pair yellow, clouded with red, with the hinder margin very brond and dusky. red; second pair reddish yellow, with the hase whitish. Very rare. Locality unknown.

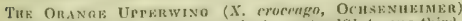
oppears in september. Wimg one incli one-twelfth to onc-third; first pair and stipmata golde'n orange, witla hrown streaks and spots, and the anterior margin spotted with white; second pair white, syith a transverse rosy wased streak towards the middle, sometumes very iudistinct. Caterpillar, yellowish, with a brown 
line on the back, and slanting orange streaks on the sides; freds on the oak. Not scarce. lifertfordshire, Surrey, Kent, and De. vonshire.

The Flouncen Rustre ( $\mathrm{X}$, rufing, Ochsenafimer) appears in September, and frergents woody places. Wings one inch one-third to one-half; first pair red, the base with a darker waved hand, the stigmata paler, between which is an angulated streak of a decper colour, then a broad posterior band of oblune confluent spots; second pair dusky, yellowish at the base, with the hinder margin and fringe red. Caterpillar, reddish brown, spotted with white, and a white line on the sides; feeds on the nak. Not very common. Essex, Hertfordshire, Kent, and surrey.

\section{GORTYNA (OcnSRNIIIMER),}

The Rosy Rustic ( $G$. miracen, Cuktis) alppears the end of July or beginnine of August. Wings one inch onc-fourth to seven-twelfths; first pair dinsky, with a rosy tinge and hrown streaks, darkent in the middle; the stigmata paler; a very slenist dusky marginal band, and fringe ashy brown with a rosy tinge: second pairiwhitish, with a hrown streak in the centre. Cuterpillar, flesh red, with small black dots, a red line on the back, and a pnle streak on the sides; feeds on bulbous ronts. Rather searce. Near London, Cork, Norfolk, Devonshire, and llampshire.

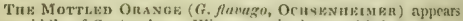
the midtle of September. Wings one inch one-thiril to seventwelfths; Arst pair kolden Jellow, sprinkleil with brown spots, and having two reddish brown bands; the stigmata yellowivh: second pair whitish, with a central crescent, two indiatinet streaks, and crescent-shaped, one at the margin, and fringe astiy brown; feeds on the pith of the burtock. Not scarce. York. shire.

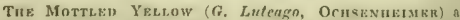
mative of Russia and llungary. Said to be British on doubtul authority.

NONAGRIA (OcHSENIEIMER).

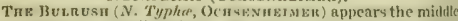
of August among hull.rushes. Wings one inch threc-fourths to two inches; fir:t pair dusky brown, with the nervores white towards the linder margin, with small black points or dots dis. posed in streaks, particularly towardis the linder edtec; second pair whitish, with a central sput, border, and margival streak composed of crescents, alt dusky. C'uterpillur, kreen, spotten with black, with a pale line on the sides; feeds on the pith of the Typha latifolia. Not scarce. Warwickstire, Essex, Midale. sex, and Surrey.

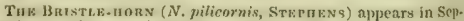
tember. Wingt one inch cleven-twelftis; first pair redlish-ash, sprinkled with a very few black dots, and having a curved strenk 
of indistinct brown spots towards the hinder margin; sccond pair white, kare, Surrey.

THS Lahoe Waincot ( $N$. crossicarnis, Straphens). Wings one inch eleven twelfths; fir at pair veined with deep yellow white, and ashy, with very numerous minute brown spote, and abnut six larger ones towards the hinder margin, disposed in an arched streak; second pair brown, with yellowish friuge. Very rare. Norfolk.

THe REEj (N. Canno, Ocuszniemer). Wings one incli two-thirds; first pair reddish ycllow, with a single series of dlusky points, forming an arclied streak towards the hiuder edge; an indistinct dusky spot in the centre; second pair yelbowish. Rare. Yorkshire.

\section{LEUCANIA (OCHSBNHBIMBR),}

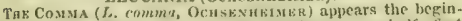
ning of July. Wings one inch five twelfths to one-half; first pair ash colour, with black lines and white nervures; second pair dusky, whitish at the base. Caterpillur, dull reddish brown, spotted with black, having three black stripes on the back; the firs segment black with three white lines; feeds on the com. mon sorrel. Rather searce. Near Dublin, Yorkshire, lient, and Surrey.

THK SHore ( $\boldsymbol{L}$. littoralis, Sremens) appears on the sea coast. Wings one incli one-half to seven-twelftlss ; first pair buff-colour, with a three-forked central live, margined with black or brown, with, white uervures; second pair white. Rare. Cumberland and Ifampshire.

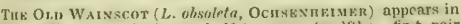
june. Wings one inch one-half to seven-twelfths; first pair jellowish brown, with a central spot and nervures white, with a streak and external margin dotted with black; second pair ashy grey, with the tip and fringe whitish, and a few small black spots on the margin. Very rare. Middlesex.

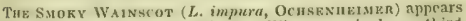
the mildle of July in woody places. Wings one inch one-third to five-twelfths; first pair yellowish brown, with the nervures wibitish, and three black spots placed in a triangle beyond, the middle; second pair greyish brown, with an indistinct central crescent, and pale fringe. Cialerpillter, straw colour, with a slender line on the back, and a dull yellowlsh streak on the sides, feels on Carices. Common. Near London.

Tив Dоттер Вокоел (L. punctini, Straness) appesurs in woody places. Wings one inch five-twelfths to one-hali, entirely redilish; first pair dotted with brown on the hinder edike; second pair pale, broadiy ashy towards the posterior angle. Not scarce, Near London.

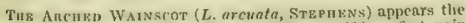
heginnieg of July. Wings one inch five-twelfths; first pair pale straw coloured, with two black spots in the centre; second 
pair white, tinged with ashy, with an arched scries of brown spots behind the middle, fringe white. Rare. Surrey.

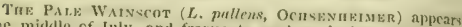
the middle of July, and frequents garkens, liedges, borders of womds and shady lanes. Wings one incli tive-twelfths to one. hatf ; fir-t pair pale dusk $y$, with white ncrvmres, and three black dots belimel the middle placed in a triangle; second pair whitish, or itu certain positions very pale dusky. C'ul/rpillor, dusky, with pale dots and four whitish streaks, Not scarce. Cumberland and Essex.

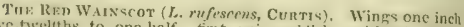
five-twilths to one-half; first prir reldish, without spots: sceond pair whitish, with the nervures in eertain lights dusky fringe white, Perhaps a varicty of $L$. prellens. Not uncommon. Cumberland and Essex.

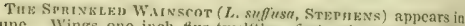
Junc. Wines one inch five-twolfths; first pair jeddish, with astiy itreahs, a central spot, and two indistinet small lines dusky. second pair whitish, with a brown clonul towards the hindir cdipe. Scaree. Norfolk, Essex, and Surrey.

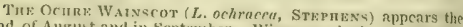
end of August and in September. Wines one inel) one.twelith; firet pair lale buff coloured without spots, very indistinct!y strcaked with dusky; second pair ashy white, darker at the margin. Rars. Cambridgevilire and fient.

Tur Wavrn Warscot ( $L$. תum, Stermexs) appears the end of Iuly. Winges one inch to one inch one-twelfth; first pitir reddish brown, with blackish spots and nervures; second pair dusky, cyes naked. Scarce. Cambridgeshire and Surrey.

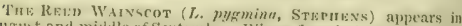
Aurust and midile of September. Wings five-sistlis to one inch : first pair reddish, with the auterior marin and frimge of a deener colour; second pair dusky; abdomen white; eyes naked; thoras redlish. Not common. Iicrtfordshire, Lssex, and Surrey.

Tuv Lign' W mar:hes. Wines threefourths of an inch; first pair whitisl huff colour, without spots, with the nervares at lie tip sprinkled will minute black spots; second pair whitish, fringe wbite; cyes naked. Rare. Essex,

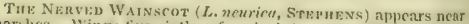
marthess. Wings five-siaths of an incin to cleven-twelfths; firt pair buft coluured or prake dusky redtish, with au arclied series of minze dusky thots behinel the middle; second pair pale whitioh ash. Rare. Cambridgeshire and Essex.

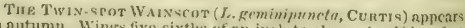
in nutumn. Wins five-sixths of an iach to eleven-twelfths; first pair dusky red, with a broal red fillet on the inner edge, and a 
small snow-white twin spot in place of the hinder stigna; second pair dusky. Rare.

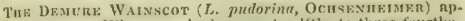
pears in Jume. Wings one inch seven-twelfths to three-fuurtis; frot pair pale dusk y red, sprinkled with black spots, nud a dark streak placed lengthways; second pair dusky red. C'aterpillar dull yellowish white, with a white stripe on the back, and a dusky white one on the sides; head brown. Not common. Cambridgeshire and Ilampshire.

THE WUTE $\operatorname{SPECK}(L$, mimunetu, STEPHEN4). Wings one inch two-thirds : first pair reddish, sprinhled with frecy, with a slanting duaky streak at the tip, and a minute white dot at the base of the hinder stigma; fringe rusty. Rare.

\section{SIMYRA (OCHSENTRTMER).}

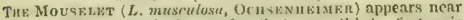
mankles. Wings onc inch one-fourth to one-thirt; first pair buff-colour, timged with greenish, without spots, nnd having the nerrures paler; sceond pair dusky, with the margin darker. Ratherscarce. Cambridgesbire.

Thy Powneris Warscot (L. renosa, Ochasmeran appeirs the midille of June. Wings one inch nne-half to twothirds; first pair hoary, sprinkled with mimite black spots, having n very slender clusky line from the base to the mirldle, and a second in the middle; second pair and abdomen pore white. Corlerpillar, above jellowish, with red, brown, and black spots and dots, a yellow line on the sicles, interrupted with brown spots, beneath redalish; feeds on Carices. Pupre black brown, enclosed in a cocoon. Not searce, Cambridgeshire.

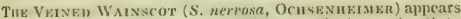
in June and the end of Angust. Wings one inch one-fourth to one-thirt ; first pair pale asloy brown, with broad whitisl lines in certain positions, with the nervures yellow; sceond pair ashculouret, with brown nervures. C'reterpilla' feeds on the clm. Very rare. Norfokk and Kent.

\section{PIHLOGOPHORA (TREIT8CFKE).}

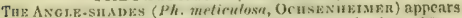
the beginning of May, beginnity of $b$ une, and beginning of September. Wings one inch three-fourths to two inclies, first pair paks rosy-white, with a triangular purpliah band in the niddle; second pair whitish, with the nervures, a central cresecent, and a streak behind the midille, and a second towarks the hinder edge, dusky. Cuferpiller, Ereen or brownish, with a white line on the back and sides; fecds upen pot-luorbs, \&8c. Pupu, bright redbrown. Common, Cumberliund, Durham, York, and kent.

CUCULLIA (SCHRANR).

Tue VAter Betony ( $C$. Srrophularia, Ochsentamer) appears in $\Lambda$ pril and Septemuer. Wings one inch two-thirds to three- 
fouths; first pair buff coloured, dusky brown at the margins, with a pale mark towards the anal angle resembling the figure 3 . second pair whitish, with a brown boriler. Caterpillar, greenisi white, the bead yellowish, the back and sides with some black and yellow spots; feels on the Verbascum and Serophularia. Searce. Suflolk, Midtlesex, Kent, Surrey, and Giloucestershire

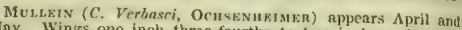
Mny. Wings one inch three-fourths to two inches; first pair blackisil brown, with the markins darker, in the middle of the inner edge is a pale white patch resembling the figure 3 , or the Greek letter $€$; sceond pair white, with a very broad blackish border. Caterpillar, ash-coloured or whitish, with yellow and black spots; feeds on the various species of Verbascum in July, Not scarce. Suffolk, lfertfordshire, and fient.

Tur Starwort (C. Asteris, Curtis) appears the beginning of July. Wings one inch five-sixths to two inclies; furst patir dizkky brown, with a very hroad whitisl streak; second pair ashy brotvn; darker in the femalc. Caterpilfur, with the head brownish, spotted with dusky, a broad yellow stripe on the back, beneath which is a narrower violet one, then a broad dull green one, and then a whitish yellow one, the legs green; feeds on various spe. eies of star-Wort. Not common. Norfolk, Middlesex, Kent, aud
Surrey.

Thi Sumpuern's Chur ( $C$. Thapsiphaga, Oczsenumann) appears in June. Wings one inch five-sixths; first pair astry white, with dusky margins and two row's of black dots towards the hinder edge. Rare, Kent.

Tна Sнане ( $\therefore$. Umbration, Ocnsenminam) appears the middle of July, and frequents low hedges, Wings one inch two. thirds to two inches; first pair streaked with hoary, with a central rusty patch, and a black longitudinal line having contiguous pillar, blackish, with thrce rows of red sy nervares. C'uler. Sonchas oleraceus and L. arvensis. Not very f feeds on the shire, Shropshire, Sufiolk, Essex, and Surrey.

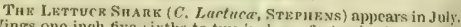
Wings one inch five-Aixths to two inches; first pair obscure ash coloured waved with brown, reddish in the ecntre; under. neath dizky, pale at the bave and markin, with three whitish spots on the upper edige; second pair dusky, with a whit. ish disk. Caterpillur, black, with white rings on the sides, and a tawny line and spot on the back; head blttek; an anterior forked white line; feeds on the lettuce, Rc. Scarce. Yorkshire, Kent,
and Surrey.

THe TANsy SHARK (C. Tunaceti, STEPInNS) appears the chd of July. Wings one inch two-thirds to five sixths; first pair streaked with hoary, having two black lines lengthwise, and three spots on the upper edge; second pair above white, with a blackish margin; undernenth spotless. Caterpillar ash coloured, spotled with black and lined with yellow; feeds on the tansy, 
wormwood, \&e. Searce. North Wales, Norfolk, Suffolk, near London, and Devonshire.

THe Nigut SuAde (C. lurifuga, SternnNs) appears the beginning of July. Wings one inch five-sixtlis; first pair of a blush ash, with black nervures and lengthwise streaks; second pair on both sides dusky, darker at the berder. Caterpiliar, dull yellow, with greenish blue spots, and four streaks on the sides; head, shining brown; feeds on Sonchus oleraceus, \&c. Not common. Shropshire.

TuE Chamomuk SHaRx (C. Chnmomilla, Strpuexs) appears in Junc. Wings one inch one-half to three feurths, ash colour, first pair streaked with black, with two liairy spots in the middle, and three ash colouretl spots on the upper edige; underneath with three white spots on the upper edge; second pair streaked, with white fringe; underneati with a small central brown crescent. Caterpillar, ash coloured, with two curved rusty lines on botli sides of earli segment; when young spotter with white and feeds on the flower of the Chamomile. Rare. Essex, Kent, Hampshire, and Devonshire.

THE Twin SHARis ( $C$. fissinn, Strphres) appears in April. wings one inch one-half to seven-twelfths; first pair streaked, clouded with brown, with a whitish somewhat ecentral spot; yellow; sccond pair brown; tail forked. Not common. Essex, Keat, Surrey, Devonshire, and IIampshire.

Tue Cumw zis ( $\left(C^{\prime}\right.$ Gnaphalii, Stepukns). Said to be British on doubtful authority.

THE Worswoon ( $C$. Alsinthit, OCHsenusisun) appears the hegunning of July. Wint one inch one-half to seven-twelfths; first pair hoary white, with black hands, and spots disposed in a square, a row of black dots on the hinder markin ; second pair whitish, with a brown band. Criterpillnr, green, streaked with yellow and red sponts; feeds on wormwood. Puja in a case, brown, anteriorly green. Not scarce. Soutli Wales, Middlesex, and Devonshire.

Tne MUg-wont Snark (C. Artemisia, OCrsennzimkn) appears in June, Wings one inch one-half; first pair green, with silvery spots: second pair whitish, with a pale ashy margin; fringe of all the wings white. ('aterpilfar' hairy, green, spotted with white, with a series of red tubercles on the back and sides; feels on the Artemisia sylvestris, P'upu green, cnclosed in a case. Rare. Oxfordshire.

\section{CALOPIIASIA (STMERENS).}

THE TOAD-FuAX (C, Linurie, STKPHENS) appears in June. Wings one fnch onc-sixth to one-quarter; first pair brownish akh, streaked with white und black, with a white kidney-shaped spot, margined with black towadds the hinder edge; second pair pade brown, with the nervures and margin disky, fringe wlite. Cieterpillar pale yellow, with a broad stripe on the back, aud 
black and wlite streaks on the sides; lical asli-colourerl, with black sputs; feeds on the Intirhinum limaria. Rare. Essed.

\section{CHARICLEA (STRRISN8).}

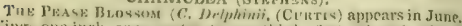
Wias, one inch ove-puarter to one-tlind; firt pair red, with a purplish band at the bave, and anotlee towards the bisuler mar. gin; on the mirgein a streak of the sime edour: frimge yellow. White, and longer than any of the Nurtuar; second pair whits, with a browa borker, outwarlly markned with purple; fringe white. ('aterpillat, yellewish, with lilack sposts, and two yellow lines; feeds on the Delphinium. Rare. Berkshire,

\section{EREMOBIA (STEPRENS).}

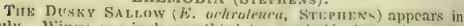
Jidy. Wings one incli one-third to oue-latf; tir-t pair varied with honry white and ash, with a flusky spot at the base of the upper, and three dokky basds; finge white, spotted with ash. colour; second pair brownish, with a dark horder; fringe white. Cinterpillar, taint yellow, with a bright ycllow strenk on the sides; feeits on wheat. Not common. Norfolk, Bedfordshire, Kent, and Surrey.

\section{ABROSTOLA (OCHSENTEIMER).}

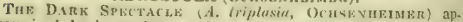
pears in . July, in gardens, and near wood silks. Wings one inch one-thiral to five-I welltis; first pair greyish brown, paler at the base, with two arched black streaks, martinul with grey, and turned in an opposte clirection; the stignatit pale browa; second gair ash coloured, witla dusky maroin. (Atrrmlla), green; the three first scements with a white streak, and the two lullowing with a black sput; feeds on the nettle. Nut searce. Hertford. shire and Essex.

TuE SPretarik (A. Asrlepindis, Orn<kNuresma) appeare the end of July an banks. Wings one incis cuse-third to one toalf, of a. brownish black, pake at the biac; fint pair wilh an arehed streak at the bave, fund another hehimd the contre, tuming in an opposite direction, with black lines towards the outer efige. Caterpultar, qule, spotted with black, with a ycllow line on the sides; feeds upon the Asclepias vitectuxicun. Rare. Nortli of England.

THE NETThe (A. Lrtice? STwPIIN appears the end of July on banks, in woorly places, हैe. Wings one inch one-third to seven-tweliths; first pair clouded with brown and graucoss, with two atched streaks, turuing contrariwise; second pair dusky. Cinterfnillur, glask-green, with a whiti-h stripe on the side's; the fourth and filt scaments with a black latch, with a white bor. der on the back, and the ofther secments laving white spot on the sides; fercls on the nettle. Common, Shopsline, Easex, and Devonshire. 


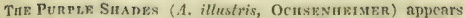
in June or July. Wings one inch one-half to two-thirels; tirnt fair brassy ash, clouded with green and clusky, of a glossy hue, with three distinct red spots, two-fold white streaks, and a wave on the outer margin; secund pair ash coloured, witl a central strcak on the hinder matgin darker. Cuteryillur, bluish green, with a yellows stripe on the sides, with three black patches on the sides of each serment; fects on aconite. I'upu fereen, with brown spots, enclosed in a wob. Rare. South Wales and Wiltshire.

\section{CALOT.FNIA (STEMINNS).}

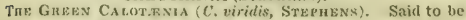
British on cloubtful authority.

\section{PLUSIA (OCASKNHEIMRR).}

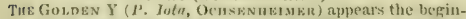
nifue of July, and frequents wooly places. Wins one inch five. twelftis to two-thirds; first pair variegated with brown grey and rust red, with fen interrupted golden character in the middle faintly resemblias the letter $1 /$ or $\kappa$ of the Greeks; the stigmata remote, bostered with fosld; seented pair redklish ash, with a slating streak, nervures and hinder margin dusky. ('uteryollur, green, with white spots; feeds on the netlle, burdesck, Ke. Incommon. Devouslite, Yorkshire, I)urham, near London, and Warwickshire.

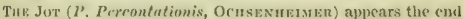
of June. Wings one inch one half to two thirds; first pair varicel with trown and rast eolorur, with an angular mark revembling the (ireck $v$ or $"$ in the micldle and contiguons sput, of bright gold colour; second pair ax in the preceding. Often comfounded with the preceling. Not common. Ilertforishire and kient.

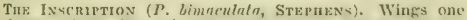
inch two-third-; first pair varied with dusky brown and rust colour, wilh two folden spots on the dise; sccond pair with a central exescent. liare.

THE Yonkshme Y ( $P$. interrogationis, OrnsnxunasR) appears the end of June or heginning of July. W'ines one inch one-fourth to five-fwellths; first pair varied with axhy brown and roxy, in the midile a V-like character aud a contiguous spot silvery; second pair slusky-prey. ('ulerpillar teeds on the nettle. (Ertien arcus). Not tuncommon. Island of Arran, North of England, but not south of Yorkshire.

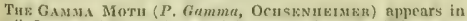
April, June, and Septeinlorr, and frequents flowers. Wings one inch one-third to two-thircls; first pair varied with frery and brown, having a silvery titure, with a perfect silvery Greek letter famma $(\gamma)$ towards the ecntre, and an adjoining rutsty spot; second pair pale ashy-brown, with the nervures and hinder 
margin deep brewn. Coterpillar, fecen, with a brotwn head, having a ycllow streak on the back, and white ones on the sides; feeds on various plants. Common. Chmberland, Durham, York, Gloucestershire, Essex, Middlesex, kent, and Surrey.

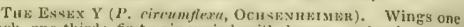
inch one-third; first pair varied with brown and ashy grey, with a pale silvery charaeter resembling the letter $V$, extending nearly from the base to the miclale; sccond pair as in the pre. ceding. Rare. Yorkshire and Essex.

THE Ruversen C. (P. bilobu, Sreprevs.) Wings one inch five-twelths; first pair purplish brown, with wavy streaks at the base, and a spot towards the upper edge near the tip, resemblixg a reversed 5 , golden; in the middie a large silvery yatch. Very rare.

THE GoLden Green ( $P$, aurifer, Ocnstninrmer.) Wings one inch one-third; first jair pale brown, witlı a large triangu. larly-shaped golden frecil patch in the centre; frimge yellow, with brown spots; sccond pair brownish; fringe dull white. Very rare. Near London, and Kent.

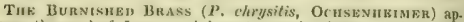
pears the end of June, and hatuuts tveedy places. Wings one inch one-third to one-half; first pair pale brown, with a brassy green band near the base, and another placed slantingly towards the hinder margin, sometimes united; second pair brown, with reddish-brown iringe. Caleryillar, kreen, with a white line on the sides, and whitish streaks above; fects on nettles, thistles, \&c. I'upre cnclosed in a reticulated ease shonth. Not uncommon. Near London, Essex, Shropshire, and Kent.

TuE Scarce Burvisura) Busss ( $P$. orichalrea, Orusentret. Mwn) appears in June. Wings one inch two-thirds to five-sixths; first pair purplish brown, paler at the base nnd tip, with a large somewhat square golden patch towards the linder margin; second pair reddish-brown. ('alerpillar, green, with $₫$ whitish line on the back, a greenish white streak on the sides, and a white spot on each segment; fecds on the hemp agrimony. Very rare. Yorkshire, Berkshire, and Kent.

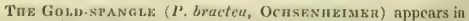
June, on heaths and mountains. Wings one inch two-thirds to fre-sixths; first pair dusky brown, with a large ansular golden glossy pateh bejore the middle. Not common. Edinburgh, south of Scotland, Shropshire, Derbyshire, and Warwickshire.

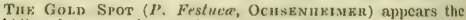
middle of August, in marshy districts. Wings one inch fivetweliths; first pair golden brown, with two golden spots in the centre, and athird more minute near the tip; second pair dusky, with red fringe. Caterpillar, green, with a dark strcak on the back, and a ycllowish mark on each segment; feeds on the bulrush and other aquatic plants. l'upn cuclosed in a case, formed by a leat of the fescue. Rather uncommon. Cambridgestire, II untingdonshire, Kent, and Surrey. 


\section{IIELIOTHIS (OCKSENHEIMER).}

THE BORDERED SA pears the befinning of June. Wings ane inch five.tovelfths to one-half; first pair runty, with redrlish brown streaks, and a broad band on the hinder margin, composed of brown crescents ; second patir yellowish white, with the base, central creseent, and border, brown. Cuterpillar, green, clouded with redulisli-brown, with a whitish stripe on the sides; feeds on the restharrow. Not very common. Essex, lient, Surey, and Devonshire.

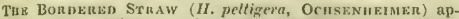
pears in July. Wings one inch seven-twelths to two-thirds, straw enloured; first pair clouded, with a row of very minute black dots on the finder margin; sccond pair with a centrul crescent, nervures and markin dusky, with a marginal straw: colourcd spot. Rare. Yorkshire, Warwickshire, near London, Sussex, Hampshire, and Devonshire.

The Marblen Chover (II. dijracea, Ochsenueimed) appears the midelle of July and August. Wings one inch one-fourth to one-third ; first pair grey, witl an irrerular reddish-brown baud behind the hinder stigun, and auother behind the middte, between and behind the stigmata a pale or yellowish square spot; second pair white, with the base, a broad central crescent, and markinal border black, the border with a whitespot. Calerpillar, red, with the head ash-coloured, the body with white lines ; feeds ujon various species of teazle, ke. Uncummon. Keut, and Sussex,

\section{ANARTA (OCUSENHETMR).}

THE BeAutifui. UNIWRWINA (A. Myrtill, Curtis) appears in June and July, on healhs. Wings tive-sixths to one inch; tirst pair rusty, with wayed whitish and dusky streaks, and a whitish central patch; second pair y cllow, with a broad brown or black borker on the margins. ('uterpillar, grass green, with a bluish lieat, the segments with yetlow and black marks, a black line on the back and sides; fecds on the whortleberry and heath. Rather common. Yorkshire, Durham, Norfolk, Kent, and Hampshire.

Thi HeArt.Bearra (.A. corligera, Strphuns). Supposed British on doubtful authority.

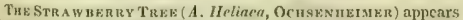
the end of July in lanes. Wings seven-twelfths to threc. fourths; first slight coppery brown, with a wavy hlack streak in the mirtdle, and a pale band townrds the hinder edge; second pair black, with a yellow band in the centre. Not scarce. Yorkshire, shropshire, It arwickshire, IIerthordshire, Essex, Kent, and surrey.

\section{ACONTIA (OCHSENTEMBR).}

THв Four Spot ( $A$. luctrosu, Oensenubrat $u$ ) appears in June in clover flelds. Wings one inch to one one-sistl, black; first pair with a barge rosy-white patch ou the upper edge belind the 
middle; second mir with a waved white band in the middle, and an indistinct white spot at the hinder edge towards the posterior angle. Centerpillur said to feed on plantain. Not common. Hertfordshire, Kent, and Surrey.

Tuk Nuv (A. npriea, OcusknfeimrR), wings one incl one-twelfth; ( $)$ first pair white at the base, fowards the outer margin black, with two spots on the upper edge of the same hue. Very rare.

THE Sor.ar (A. Solaris, Ocusevurimer). Wings one unch five-tweliths; first pair white at the base, brown at tlie tip, with a square white spot on the npper edere; second pnir white, with a brown border. Catermillur, sтey, with the head brick-red, each segment with two white spots; feeds on the trefoil, dandelion, \&c. Rare. Near London, and Kent.

Tha Culoric (A. Culoris, OchsinuFiner). Jingsone inchone. third; first jair snowy white at the base, streaked with bluish, marbled in other parts with brown fand bluish, with a white square spot at the anterior margin ; second yair vvhitish, with a broad brown marginal border. Very rare.

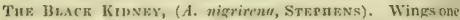
inch one sixth; whitish, spotted with brown, with the first stigma dot-shajed, and the hiuder one large, black, and kidney-shajed. Very rare.

EUPIIASIA (STETHENS),

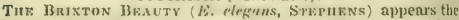
middle of september. Wings one inch one-third, very white; first pair with a white band towards the linder margin, and two spots on the upper cdze, olive brown; a marginal row of brown somewhat eje-like spots, di-posed in a chain; second patir with a blossy purplish tinge in certain lights. Very rare. Surrey.

\section{ERASTRIA (OCHSRNTEIMER).}

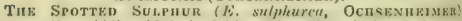
appears the midale of July in ficlds. Wimgs five-sixths to eleventwelfths ; first pair primrose yellow, with five black squts on, or near the upper cisc, and four in a row on the hinder margin, and two rather thick black streaks; second pair lorow'n, with d whitish fringe. ('aterpillor, grass-green, with a black line on the hack, asd a yellow streak on the sides; fecels on the Convolvelus arvensis. Rare, Kent and Surrey.

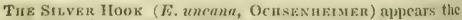
end of June, in marslies. Wings eleven-twcliths to one incli, brown; first pair with the exterior margin whitish; from the middle arises a bent twig; the fringe of all the wings dusky, with a dark base line. Cuterpular, freen, with a pale line on the sides; feeds on Carices. Not rare. Cambridgeshire, Nortolk, Devonshire, and Hampshire.

THE SHVER-Barred ( $E$. Bankiana, Stepiess) appears the 
end of June or beginning of July in boggy places. Wings fivesixths to eleven-twelfths of an inch; first pair olive brown, with two snow-white bands, the outer one with a sinfle tooth; near the tip of the upper edge is a small comma-siraued white spot. Caterpillar green, with a white line on the sides. ltare. Norfolk.

Tue Rosy Marbled ( $E$. venustula, Curtis). Wings twothirds to thrce-fourths of an inch; first pair whitish, brown in the centre and at the outer margin, with a central rose-coloured and a rather large blackish spot towards the inner edge. Faterpillur redish brown, with two broad orange-yellow belts, and a dusky stripe on the back and curved streaks on the sides. Very rare. kisex.

The Difarp Mandes (E. minuta, Ochgenhemer). Wings three fourths of an inch; first pair variegated with white, brown, lead colour, yellow, red, and olive; the base white, the hinder edge with a ruw of minute black dots; second pair brown, with the margins darker. Rare. West of England.

The Scancet (E. ostrina, Cuntis) appears in Junc. Wings three-fourths of an inch ; first pair yellowish white, with violet streaks, and a white indented streak next the hinder margin. Very sare. Devonshire.

Tне Buossom Tup (E. apirosa, Stepnens). Wings one inch; first pair glossy black from the base to beyoud the middle, with a marginal border and stigmata purplish; second pair brown, with a darker spot in the centre. Very rare.

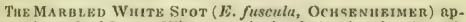
pears the end of June. Wines one inch; first pair asla coloured, lariegated with brown, black, and white; towards the posterior anglea white oblong patch, behiud which is a white streak cross. ing from the upper edge to the inner margin. Caterpiller, yellow, with a broad reddish streak on the back, and line on the sides; feeds on the bramble. Scarce. Kent and Surrey.

The Marble1) WutTe Linf ( $h$, albililinea, Steptinss) rery similar to the prececting, of which it is urobably a varicty, and from which it differs in the absenee of the white spot at the posterior angle, and having the white waved streak at the hinder elge very indistinet. Fery rare. Kent and Surrey.

\section{PIIXTOMETRA (HAWORTH).}

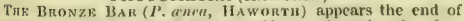
Aurust on heaths. Wings seven-tweliths to three-fourths of an inch, olive brown; first pair with a slanting purplish band behind the middle, and another on the hinder margin. Not searce. Hertfordshire, Kent, and Surrey.

\section{ACOSMETIA (STEPHENB).}

The Rro Bupr (A. lateserns, Streruens) appears in July. Wings one inch to one inch oue-sixth; first pair nearly uniform 
reddish buff, red at the upper edge; second pair pale brown. Rare. Hampshire.

THE Sootr (A. caliginost, StEruENs) appears in Juns. Wings one inch one-twelfth; first pair red or dusky greyish, with ubscure indistinct streaks; sccond pair grey. Rare. Ilamp. slire.

Tri Divang Ren (A, mfula, Stepmens). Wings five-sixthi to eleven-twelttis of an inch; first pair and fringe of a uniforin red; second pair pale, with a central streak of disky spots; fringe pale. llare. Norfolk and Cambridgeshire.

TuE Ltand Burp (A. lineola, Steriens). Wings five-sixt'ss to eleven-twelfths of an inch; first pair grey red, with a dusky streak lengthwise at the base, and another at the linder margin, composed of minute dusky dots: second pair jalst, with a streak of obscure syots behind the midule. Rare. Cam. bridgeshire and Norfolk.

Tue SaAj.z Dot Buff (A. arcuosf, Sterimss). Wings one inch onc-twelfth ; first pair dulk whitish clay, with two streaks of minute dusky dots; second prir and fringe dusky. Rathes scarce. Hertfordshire, Essex, Middlesex, and surrey.

\section{SCOPELOPUS (STEPIIENS).}

THE BRUsmzоoT (S. inops, STEPIENS). Said to be British on cloubtful authority.

\section{STILBIA (STEPHENS).}

THE Anomalous ( $S$, momulutu, STBPHENs) appears in aultumn. Wings one inch onc-third to one-half; first pair ashy brown, clouded with black, the ordinary stigmata pale and divaricated; second pair pale. Scarce. Hants and Devonshire.

\section{OPHIIUSA (OCHSENHBTMER).}

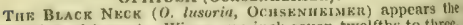
heginning of August. Wings one inch seven-twelfths to three. fourths; first pair glaucous irrey, with a black blotch in the middle; the hinder margin with a broaul dusky border; second pair pale brown, with the margin clarker; collar black. Caterpillus, grecnish grey, with black spots and two clark lines, and an ia. termediate yellow one; feeds on the Astragalus glycyphylus. Not searee. Yorkshire, Kent, and Surrey.

Tue Scarce Black Neck ( $O$, Indicta, Ochshnmbinki) Wings one inch two-thirds, brown; tirst pair with a dot and central pateh black, and two indistinct strcaks towards the tip. Very rare.

Tre Dovale Barrad (O. crassiuscula, Stepunns). Wing one inch two-thirds; first paix greyish brown, with two bands of a decper tint, a spot in the middle, and a patch towards the tip black, Very rare. North of England. 
TME GREAT KinNiv (O. gradivena, STrpmens). A native of America, reported to be British on doubtrul nuthority.

\section{CATEPIIA (OCHSENAETARR).}

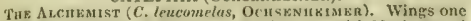
inch three-quarters; first pair dusky brown, with black waved streaks; the hinder margin ash-coloured; second pair black, with the base and two marginal spots white. Caterpillar, ashcoloured, with yellow spots and bluish head; feeds on the oak.

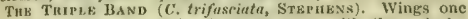
inch five-sixths; first pair glaucous grey, witl three dusky lands; second pair brown, with the margin darker. Rare. Sufiolk.

\section{MORMO (Осн8ENHEMMR).}

TuE Orn Lany ( $M$. maura, OchsENusimkr) appears the end of Juy or begimning of August. Wings two inches two-thircls to three inches, deep brown; first pair varied with ashy and black, with a broad central band, and seven brown spots on the upper cdge; second pair with a pale slanting contral streak, and another near the hinder margin. Cuterpillar, deep brown, with $\mathrm{n}$ whitish line on the hack; head ycllowish; fecds on lettuce and other pot-herbs. Common. Shropshire, Essex, Kent, and Sur. rey.

\section{CATOCALA (SCHRANR).}

Thr Asur Tree (C. Fruxini, Contis) appears in July and September. Wings three inches tive-sixths to four inches; first pair whitish, clouded with ash grcy; second pair black, with a broad blush band hehind the middle. C'uterpillar, ash-coloured, sprinkled with minute black rlots; fecds on ash, joplar, oak, elm, \&c. Hare, Yorkshire, Kent, Suffolk, and Surrey.

Tue Chosen (C. Elocata, Strepiens). $\Lambda$ native of Portugal; said to be Britisli on doubtful authority.

THE WHE (C. Nupta, OCHskNtEIMkR) appears among willows the beginning of Aurust. Wings three inches to three inclies one-lhalf; first pair aslıy, with various waved streaks, the last unequally indented; second pair reel, with a central band and margin black. Calerpillur, varied with dark and pale brown, with ycllow spots and streaks; feeds on Salix vitelliaa. Common. Shropshire, Norfolk, Suffolk, and Essex.

The Enanern (C. Pacta, Steriens). Sald to be British on doubtiul authority.

THe l3kiDE (C. sponsa, Ocnsenumimen) appears the end of sune. Wings two inclies onc-lialf to three inches; first pair of a yellowish ash, waved with brown; second pair loright crimson, with a very wavy band in the centre, and marginal border black. Caterpiller, with a bluish head, the body variegated with brown and light ash; feeds on the oak. Puja bluisl. IRare. Kent, Surrey, Berks, and Ilants. 
The Prosisen (C, promissa, Ochsenitermar) appears the end of June. Wings two inches one-quarter to five-sixtlis ; first pair ash-coloured, with black wavy streaks; secomd pair rich crimson, with a narrow wayy shortish black band towarls the middle, and a black marginal border. Caterpillar, bluish ash, with black spots; fecds on the oak. Scarce. Surrey and Hants.

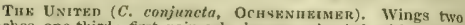
inches one-third; first pair ashy brown, clonked with black; sccond pair rich crimson, with a nearly straight, slender, and somewhat line-like black band in the middle, and broad black marginal border. Rare. Surrey.

\section{BREPHA (HÜBNRR).}

TuE VIroin ( $B$, Purlhemias, OchsFnikimisr) appears the end of March. Wings one inch to one inch one-third; first pair brown, sprinkled with asliy-grcy; second pair pale orangc, with a spot at the base, an angular band in the niddle, and the mar. ginal border black. Caterpillar, yellowisl-preen, with a bluishblack line and black spots on the sides; feeds upon poplars and willows. Not rare, Essex, Herts, Midillesex, Kent, and Surrey.

TnE Girl (B. meella, Ochsкnнвimez). Wings one inels one-quarter; first pair ashy brown, with indistinct darker bands; second pair yellow, with a bloteh at the base, a central band, and hinder margin black. Cuterpillar, violet, with a white line on the bnck aud sides, ench segment with two spots on the middle under the line on the back; feeds on the aspen. Very rare.

THE HAzeL (B. notha, OCHSFvinimer) appears the end of March. Wings one inch one-sixth to one-third; first pair rusty, sprinkled with ashy grey, having white spots; second jair bright orange, with a patch at the hase, an angular band in the centre, and an interrupted marginal border, black. Caterpillar, green, weeds a yellowish line on the back, and a grey one on the sides: feeds on the oak, birch, and hazel. Rather searce. Yorkshire,
Essex, Kent, and Surrey.

\section{EUCI,IDIA (OCHSIENHEIMER).}

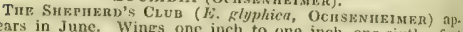
pears in June. Wings one inch to orte inch onc-sixtl, fort pair greyish, with an oblique band before and anotlier bebind the
middle, a square spot on the upper edge near the tip, and a mar. ginal band, urown; second pair yellow, with the bese, streaks, nervures, and hinder marpin blackish; all the frimges brown. Caterpillur, rusty grey, with a brown streak on the back and sides, the latter have a row of blackish dots above and beneath the streak; feeds on the Verbasci and Trifolium pratense. Not nneommon. North Wales, Derbyshire, Iorkshire, Ifuutingdon.
shire, and Essex.

Tuz Tumes Cornans ( $C_{\text {. }}$ triquetra, Ocusenuenmen), Said to be British on doubtful authority. 
THE MASK ( $F$, Mi, OchsENminar) Rppears the end of June. Wings one inch to one inch one-sixth; first yair varied with black aul white; sccond pair black, with spots and waved streaks white, all the fringes white, spotted with black. $C u$. terpillar, reddish white, with a dark line on the back, and a whitish one on the sides; head brown, with pale stripes and dark spots; fecds on the Medicago falcata. Common. Wales, Yorkshire, Suffolk, IIuntingdonsture, and Essex.

\section{GEOMETRINA (RENwIE).}

\section{GEOMETRID R (STEPHENS).}

PSODOS (TRETRCHKE).

TuE Bi,ack Mountain ( $I$ '. trepidurin, Traitscires) appcars in June. Wings five-sixths of an inch, smoky black, with a central band of a deeper tint, on both sides indented with a pale margin. Local. Schehalion, in Breadalbanc, Scotland.

Tав, Gor.n Four-spot ( $P$. alpinata, Duponerer). Wings one inch, black, with a broad golden tawny baud near the hinder margin. liare. Kent.

\section{SPERANZA (CURTIS).}

Tuz EMenoiderad Yellow (S. limbria, Curris). Wings one inch one-twelfth to one-sixth, ycllow, with minute brown dots, the antenna, upper cdge of the wings, and hinder margin, liack. Culerpillar, smooth, slender, green-brown, with a yellow stripe on the sidies; feeds on the broom. Not rare. Kent.

Thz Woonsañ (L. sylvaria, Cunris) appears in July. Wings five-sixths to eleven-twelfths of an inch; rusty buff colour, jowdered with dusky, having dark waved cross strcaks. Rare. isle of Arran, Scotland.

\section{FIDONIA (TREITSCIKE).}

THe WAven BuAck ( $F$. fuliginaria, StкpHENs) appears in June. Wings eleven-twelfths of an inch, black, witl three yellowish raved interrapted streaks, and near the margin a common indistinct streak of yellowish clots. Excccingly rare. Near Loncion.

Tik: Brown Iвати ( $F$, atomaria, HaworTн) appears in May, June, and August. Wings one inch to one inch oue-fourth, yellowish white, sprinkled thickly with brown dots, with five conjoised common streaks, and marginal border of a decper colour. Caterpillus, at first green, with redish spots on the sides, with a brown stripe on the back, on each side of which on each segment are small triangular decp brown spots; feeds on Scabious. Pupa subterranean. Common. Dumfriesshire, Cumberland, Durham, Yorkshire, Hertfordshire, Essex, and Kont.

TaE BLACr HEATH ( $F$. carbonariu, StepHans) appears the 
middle of June. Wings eleven-twelfths of an inch, pitchy black, with small white spots or blotehes, fringes white and brown; antenna black, irregularly narked with white rings. Perhaps a variety of $F$. atumarin. Not rare. Near London.

Thr Grex II vati ( $F$, ericetarit, Stephins) appcars in Au. gust. Wings of the male one inch seven-twelfths to two-thirils; female one inch one-fourth to one-half; ashy white, sprinkled with brown dots, and having a brown marginal band; first pair with three equi-distant brown spots on the apper edge; second pair with a brown central spot. Not rare. Kent, Surrey, and Hampshire.

\section{BUPALUS (LEACH).}

THY Bondered Wurt (B, Piniurius, LaAcu) appears the midclle of June, in fir plantations. Wings one inch one-tialf to two-thirds, brown, spotted with yellow, clouded underneath, with two brown bands. Caterpiller, green, witis a line on the back whitish, followed on earh side by a yellowish white and yellow line; ifects on the Pinus sylyestris and $P$, alies. Nut common. Scotland, Northumberland, Norfolk, and Surrey.

\section{MASIA (STEPHENS).}

Tue Grey Scollop bar (S. furillacearius, Steprens) appenrs in June. Wings of the male one inch five-twellths to seven-twelfths; female one inch one-thirit to one-half, ashywhite, with a black spot in the eentre, the margin with a row of black dots, fringes brownish; forst pair with two black streaks, accompanicel with two black spots; sccond pair with a single streak. Scarce. IIampshire.

\section{ANISOPTERYX (STRPHENS).}

The Sprino Usuer (A. leupophearia, Stephens) appears in oak woods the end of lebruary and March. Wings one inch onc-third to two-thirds, ashy grey, clouded; first pair with \& black curved strcak at the base, and another wavy behind the middle; second pair whitish, witl numerous brown dots, with a central streak composert of a few distant black spots; the female has only very short indistinct wings, with three retidish grey lines, sprinkled witl dusky, and having two black strcaks; varies much. Very common. Durham, Essex, Kent, and Surrey.

Tue WAle UsurR (A. Aiscularia, StepunNs) appears on palings and trunks of trees the middle of March. Wings one inch one-thiri to nne-half, ashy-brown, with a band in the centre margined with white, outwardly indented and deeper, and a brown slanting slender line at the tip, the margins with a row of minute black spots, fringe pale brown; the female without wings, of a mouse colour, with pale grey dots on the head and breast. Caterpillar, green, with a white line on each side of the back, and another above the legs; feeds on the privet, sloe, and horve-chestnut, Rather common. Cumberlausd, Essex, and near London. 
HIBTRNIA (LATREILLK).

Tuz Cross Wino ( $I$, capreolaria, Duponcrel, appears in Feb. ruary and March. Wings ne inch one-third to seven-twclfths; furst pair reddish grey, sprinkled with rust-brown spots, with a darker straight streak before the midule, snd a marginal band, in which is a row of pnle spots. Caterpillar, fawn yellow, the four first segments with brown, yellow, and red lines, the body with brow'n and yellow dots and lines, a row of white dots on eacb side; feeds on oak and birch. I'vpa grecnish brown, Common. Cumberland, Durham, Essex, and ncar London.

THв UMBRE LINk ( $I T$. connectarin, StepheNs) appears in Norember and December. Wings one inch seven-twelfths; first pair speckled with dusky brown, with three equi-distant brown streaks, and a pale square patch on the upper edge near the hinder margin; second pnir whitish, speckled with dusky dots, with two strcaks in the middle, and an intermediate spot, brown. Rather scarce. Essex, and near Loudon.

Trв Scance Uмвве (L. prosapiaria, Stzrmens) appears in october or November. Wings owe inch one-half to two-thirds; first pair tawny orange, spriukled with brown dots, with two slonting brown streaks, and a spot of the same tint in the centre; second pair pale tawny yellow, with a central spot, and a single streak, brown; varies much. Caterpillar greenish, with a brown line edred above with white on cach side of the body above the stigmata; head and lego pale orange; feeds on the oak, birch, and horn-beam. Pupa brown. Rather scarce. Edinburgh, Essex, Kent, and Surrey.

Tue Uмпве (C. defoliaria, Strmines) appears the end of October, in woods and copses. Wiugs one inch seven-twelfths to three fourths; first pair whitish, grey or rusty syeckled, with two dusky streaks, and having a central spot; sccond jair paler, with a brown central spot. C'alerpillar, rust brown, with a bright yellow streak on the sides, and a red spot with a white dot on each segment ; feeds on onk, lime, becch, \&c. I'upa reddish brown, with the tip yery acute. Common. Cumberland, Issex, and near London.

\section{PIIIGALIA (DURONCHEL).}

Thr Winter Bhauty ( $\boldsymbol{l}^{2} h$. pilosarin, StEPIENS) appears in March. Wings one inch one-halt to two-thires; RTcenish ash sprinkled with dusky, with a ecntral spot and four inter* rupted streaks, black; the streaks arise from equi-distant spots on the upper edge; second pair similar, but pale, with a single streak in the centre, the fringes with a slesder brown line more or less interrupted. The femalo without wings. Cuterpillar, yellow, varied with reddish brown, with red spots and black dots; feeds on oak, birch, clin, \&c. in June, fugn brown. Scarce. Chcshire, Shuopslire, Warwickshire, and Surrcy. 
NYSSIA (DUPONCHEL).

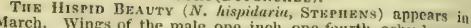
warch. Wings of the male one tuch one-fourth, ashy-brown, with three dnsky streaks, the two first waved, and the hinder one wavy, fringes pale, with dusky rather square spots; second pair dusky, with a dark central line. Female without wings, th. terpilin, brown, with dark square spots; feeds on the elm. Rare.
Shropshire, Kent, and Surrey.

\section{BISTON (LEACI) ,}

Tü OAK Beavtr (B. prodromurius, LeAcri) appears in March or April. Wings of the male one inch one-half, temale one inch two-thirds to two inches one twelfth, whitish, powdered with dusky, with two wavy brown bands terminated with black; varies much. Caterpilln, variable; brown or ash colour, mar. bled with yellow or dusky, with white dots and fourteen spiracles; feeds on the oak, lime, \&e., in June. Pupa chestmut brown, with the spine terminating in two hooks at the tip. Rather
scarce. Yorkshire, Warwickshire, and near Lonton.

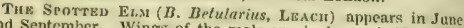
and September. Wings of the male one inch one-half to five. sixths, female two inches one-fourth to one thircl, white, thickly sprinkled with black, clouded; second pair laving sometimes a black wavy streak behind the middle, body white, corselet with a bedack band. Cuterpillur, variable, Ereenish, or brown, with a reddish line on the back, - or ashy-erey, with two warts on the eighth, and two on the eleventh segment; feeds on oak, willow, rose, \&c. Pupa brown, with a longspine at the tip. Common. Yorkshire, Durham, Cambridgcshire, and Scotland.

THe JrRnded Brautr (B. hirturius, Lwacer) appears in April. Wings of the male one inch one-half to two-thirds ; female one inch two-thirds to five-sixths; hoary, yellowish, or grey ur dusky, with black cross streaks approximating at the hinder male with the wings similar, with only two cross strcaks. Female with the wings grecuish, more translucent, and the markings less distinct. Cinterpiller, brown spotted with grey, with ten feeds on poplar, lime, elme back, legs yellow tipped with reddisli: feeds on poplar, lime, elm. Pupa short, dirty black, with a fine
point at the extremity. Not searce. Near London.

\section{IIIMERA (DUPONCREL).}

Tú Featuenen TuorN (H. pennariu, StepheNs) appears the beginning of October in woods. Wincs of the male one inch three-fourths to two inches, female one inch one-half to two inches one-fourth; first pair reddish, with two thick streaks at the upper edge, and an Interjacent spot, brown, and a black spot at the tip, bordered with white; second pair paler, with a central dusky spot and roddish streak; female paler. Caterpiller grey, varied with brown and white, with two reddish warts on the last segment, and two red spots on the first; fecels on the oak, becch, 
horn-beam, \&c. Not uncommon. Chester, Essex, and near London.

\section{CROCALLIS (TREITSCEKR).}

THK Sconiofen OAK (C. elinguri, Orusknnkmen) appears in June. Wings one inch one-half to two-thirds, ycllow; first pair with two darker strcaks, having a dusky spot between them; second pair paler and spotless. Caterpillar, thick, dirty, brown, with a few hairs; feeds on the onk, elm, aplple, \&c. Rather scarce. Durham, Essex, and near London.

\section{ODONTOPERA (STETHTNS).}

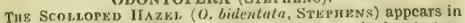
April and June in woods and conses. Wings two inches to two inches one-sixth; first pair redelish brown, clotted, with two waved streaks, aud an interjacent ring, hrown; sccond pair paler, with ad eye-like spot on the disc, belined which is a dusky waved streak. Coterpillur, frrey, marbled with freyish red or Freen, sometimes green with black or white spots ; feckls on the rose, willow, alder, fir, \&ec. 1'upte thick, smooth, chestrut brown. Not scarce. Durham, Essex, and near London.

\section{GEOMETRA (LRACI).}

Tuk Alper (G. Alniaria, Strpurns). Said to be British on doubtful authority.

Tre Canary (G. Canaria, Strputens) appers the end of Augrust. Wings onc inch one-third to ono half, in both sexes nearly yellow, slightly clouderl witl dusky, margins sometimes spotted with dusky; firat pair with two streaks and a crescent between them of a dark yellow; second pair with a dusky central crescent; corselet primrose ycllow. Rare. Near London.

THE OCпке (G. orhraria, SrepHeNs). Wings one inch one. fourth to tive-twelfths, pale orange buf wilhout spots; first pair with two yellowish streaks, and an indistinct crescent between them of the same tint, corselet brifht pale yellow. Scarce. Kent:

Tirs Septembr TuokN (G. crosaria, Stefuens) appears in Aukust and September in woods and parks. Wings one inch one third to seven-twelfths, deep yellow; first pair abrupt at the tip, with two slanting nearly straight streaks in the centre; second pair angular, indented, without spots, sometimes with an indistinct cross ecntral streak; corselet anteriorly tawny, posteriorly yellow; female rather darker. Common. Near London.

Tir August OAк (G. Quercinaria, НАworth) appears in August. Wings one inch nne-third to two-thirds, tawny, with evanescent darker dots; first pair with two darker streaks, the first of which is angular near the upper edge, and the hinder slightly curved, hinder margin abrupt; second pair without spots, with an indistinct cross streak; corselet slender, tawny; 
fomale with the wings whitish yellow, with the nervures, dofs, and two cross broad streaks, brown. Common. Shropshire, War. wickshire, and near London.

THE ANGLEU OAK (G. Quercarin, Hähnet). Wings one inch one-half to two-thirds, in both sexes, whitish grey; first pair, jagged, with two brown streaks and a dusky incleter. minate band adjoining the second streak outwardly, corselet pale whitish-grey; second pair with a distinct cross streak, and margin dusky. Rare, Near London.

THE Analen THonn (G. angularin, Itinnza) appears the end of August and beginning of September. Wings one inch one-third to two-thirds, tawny ; first pair with two cross some. what parallel brown strcaks, and an indistinet dusky crescent between them; second pair with an olsscure cross central streak and the hinder margin darker; female paler. Calerpillar, reddish brown, underneath greenish, with black spots and white dots, the spiracles dusky with their tips greenish; head and fore-legs yel. low; feeds on the oak, lime, Rc. I'upu pale green, with the abdomen yellow. Common. Near London.

THE Flounced THorn ( $G$. Carpiniaria, IIflaner) appears the end of Augrust. Wings one inch five-twelfths to one-haif, first pair pale tawny, abrupt, with two cross dusky streaks, fand an indistinet ereseent between them, the space from the second streak is dusky ; second pair dusky. Rare. Near London.

THE Dusry THoRv (G. fuscantarin, Itawortr). Wings one inch one-third to five-tweliths; first pair abrupt tawny ash, with two cross dusky streaks, the sjace from the second streak to the hinder margin dusky; second pair in the female entircly dusky; in the male dusky from the base to the middile, and the remainder tawny. Scarce. Cambridgeshire, and near London.

THE EARนY THOIN (G. illunaria, Hibnen) appears the end of March and beginning of April. Wings one inch seven-twolfth to three-fourths; astiy red, sprinkled with redilish ; first pair with three somewhat equi-distant dusky red streaks in the centre; second pair pale, with an indistinct streak. Cuterpillur, krey, with rust-coloured rings, with black and yellow spots at the base of the spiracles and on the sides; sometimes brown, with a rusty red line on the back, and large red spots on the sides of the hinder segments; feeds on oak, willow, ajder, 太kc. Not scarce. Yorkshire, Essex, and near London.

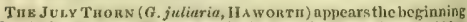
of Joly in woods. Wings one inch two-sixths to five-twoliths, very similar to the preceding, but much smaller in size, the streaks not being equi-distant, and more indlistinct ; the wings also not Ro much sprinkled, and having a rosy tioge on the upper edge. Common. Essex, and near Jondon.

The LUnar ThorN (G. IUnaria, IIawortir) appears in June. wings one inch five-twelfths to two-thirds, whitish grrey, with indistinct sprinklings, and a central white crcscent; first pair with two brown strcaks. Caterpillar dirty green, mottled with 
darker colours, and having the appearance of a piece of bark; feets on the white thorn. Scarce. Roxburghshire, Shropshire, Yorkshire, Warwickshire, Kent, and Surrey.

TH. KЕNT THORN (G. delunaria, HАพовтк) appears in July. Wings one inch onc-half, whitish grey, with an oblique dusky streak before the middlle; first pair with an incurved streak in the nicldle; second pair with two dusky streaks in the midlde, and adjoining the outer one an obscure transparent crescent. laare. Kent.

The Subuvar Tuon (G. sublunntu, Stepmkns), Wings one inch one half to two-thirds, decply indented with a small white erescent; first pair from the base to behind the centre red. brown, with three dusky streaks, and the remainder purplishwhite; second pair reddish, with a brownish band. Rare. Derbyshire.

THE PURP E THORN (O.illustrarit, IIAWoRTH) appears in June. Wings one inch two-thirds to two inches one-twelfth, notehed from the base to beyond the middle, commonly varied with brown and ashy, with a whitisl crescent towards the upper edge of the first, and in the centre of the dise of the second, pair, with a purylish white border. Cuterpillur, brown, with whitish stripes on the sides, and brownish spots; feets on oak, kcc. Kare. Kent, and Hampshire.

\section{PERICALLIA (STEPRENS).}

THF LILAC BEAUTX ( $P$. Syringarin, STE PHeNs) appears the end of June, or beginning of July. Wings one inch one-half to two. thirds, notched, ycllowish grey, withi a somewhat short angular violet strcak before the middle, and two others behind, of which one is brown and the other brown and violet; first pair with a violet crescent at the tip; sccond pair with some black spots towards the inner cdre; female larger and paler. Caterpillar, variel with black and brown; feeds on privet, lliac, willow, \&c. P'upa thick, brown. Scarce. Salop, Cambridgeslire, Warwickshire, Essex, Mitdlesex, Kent, and Surrey.

\section{ANGERONA (DURONCHEL).}

Tur: Puama Onangr. (A. I'runuria, Strpinss) appears the end of July. Wings of the male one inch five-sixths to two inches, female two inches to two inches one-sixth, in the male ligight orange; in the female yellow, powdered with dusky, a dlusky crescent in the middle, the hinder margin sometimes dusky; fringe of the second pair with browa spots. Caterpillar, rust brown, with pale spots on the sides, liead and spiracles redilish; fecds on the elm, sloe, white thorn, \&c. Common. Westmoreland, Warwickshire, Essex, and near Loudon.

RUMia (DUPONCHEL).

Tuв Bristone (R. C'ratayata, Sterhens) appears in April, 
June, August, and October. Wings one inch one-sixth to twothirds, deep sulphur colour, with four red spots on the upener edge. Caterpillar, pale brown, with a bluish spot on each vile behind the heart, with the spiracles on the sixth segment slightly tinged with reddish; feeds chicfly on the white thorn, sloe, apple trec, \&e. Common. Dublin, Edinburglt, Ayrshire, Cum. beriand, Durham, Wilts, Essex, and ncar London.

\section{OURAPTERYX (LEACH).}

The Eldok (O. Sambucaria, LkAcu) appears the end of June, or begiuning of July. Wings two inches one-fourth to nne-half, palc silphur colour, with various obscure cross scattered darker evanescent lines; first pair with two dasker yellow streaks, with an interjacent line; second pair with a sinrle streak and two black spots near the tail. Catcrpillar, dull redclish brown, with darker lines; feeds on the clder, willow, lime, Rc. P'upa longish, brown, with deeper spots. Not searce. Yorkshire, Durham, Cambridgeshire, Iluntingdonshire, Kent, and Surrey.

\section{CAMPAEA (LAMARCk).}

Tue Ltont Eneraid ( $\boldsymbol{P}$, murguritatu, Striptuns) apjears the middle of July, or beginning of August. Wings one inch seven. twelfths to two inches, white tinged with green; first pair with a red spot at the tip, and two whitish streaks, and the second pair with one; all the fringes pearly white. Cuterpillar, green. ish, varied with brown, with whitish spots on the back and sides, bencath with black streaks and dots; feeds on the horn. beam, oak, \&c. Common. Yorkshirc, J Iuntingdonshire, Essex, and near London,

\section{ELLOPIA (TREITSCHKE).}

TuE Baften RED ( $E$. fuscimiu, OCHskninimen) appents the middle or end of June. Wings one inch five-twelfths to seventwelfths, red; first pair with a whitish streak before, and ano. ther behind the middle, the interposing space of a darker hue, sccond pair with a single whitish curved streak; female larker, with the antenne bristle-shajed, and without the darker shade between the streaks on the first pair. Caterpillner, red, varied with brown and white, with the head red; feeds on the pine. Scarce. Fifeshirc, Kent, and Surrey.

\section{IIIPPARCHUS (LEACH).}

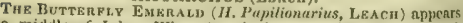
the middle of July. Wings two inches one-sixth to ane-half, deep grass green, with two cross strcaks composed of whitish spots; nd dark green erescent towards the middle of the upper edge of the first pair, and on the dise of the second; antenare reddish white, with red rays in the male. Cuterpillar, green, with a ycllowish line on the slies, and red warts on the back; fecds on the lime, birch, alder, \&c. Pupa brownish, with yel. 
lowish green'spots. Rather scarce. Yorkshire, Warwlckshire, Kent, and Surrey.

\section{CHLORISSA (STBPHENS).}

THe Grass EMerald (C. viridata, STEPHins) appears the end of May and June. Wings five-sixths to eleven-twelfths of an inch, entire, very green, with an indistinct whitish streak before the middle on the first pair, and another behind the middle commen to all the wings; fringes reddish green. Scarce. Essex, Surrey, and Hampshire.

The Mirmaid (C. clorarit, Strapens). Wings thrcefouths of an inch, green, with a common whitish streak behind the middle, the fringes entirely green. Very rare.

TuE Common Emrralo (C. thymiario, Stephens) appears the end of June. Wings one inch one-twelfth to one-sixth, dark green, the fringes white, spotted with dusky ; first pair with n whitish wavy streak before the midile, and a second behind, conmon to all the wings; the second pair are angular, with a very indistinct darker spot in the centre. Caterpillar, green, with dark clouts; fceds on the oak, whitethorn, \&e. Common. Egsex, and London.

Tub Little Eariand (C. putatarin, Steruens) appears the end of May, in woody places. Wings five-sixtis to eleven. twelfths of an inch, pale reeen, with two common indistinct whitish streaks, and a very indistinct interjacent blotch. Cuter. frillar, green, with small red spots; feeds on the birch, hornbeam, sc. Common. Cumberland, Yorkshire, and near London.

\section{IIEMITHEA (DUPONCHEL).}

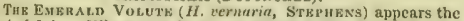
enul of July. Wings one incli une-fourth to five-twelttlss, of a bright pale grcen, a somewhat wavy streak behind the middle, and the fringe white; the tirst pair has also an incurvad streak before the middle. Caterpiltar, green, with a pale line on the back, and a white stripe on the sides, the head with two reddish spines; feeds on the oak, sloc, \&ec. P'upa brownish. Rare. Kent, and Surrey.

Cuktis's EMERALD ( $\boldsymbol{I}$. smuragdurit, STEPHzNs) appears the chi of June. Wings one ioch five-twelfths, green; first pair with two wavy pale buff streaks, with a white spot between; second pair with the upper portion and frimges whitish. Kare. Essex.

Thk GaEen CARpet ( $I I$ Cythisaria, StepunNs) ajpears the end of July, on licatlis, $\mathrm{ke}$. Wings one inch five-twelftlis to one-half, delicate pale green; first pair with an incurved clark green strcak before the middle, and a waved one behind with an interjicent lark crescent; the second streak is common, and also a third whitisi and evanescent towards the binder margin; fringes pale. Caterpillar, green, with a pale line on the sides; 
feeds on the broom. Pupa slender, and yellowish green. Comraon. Essex, and Surrey.

CLEORA (STEPHBNS).

TIR MAID of HoNoun, (C. bujultria, StEptupss) Rppears the beginniug of July. Wings one inch one-twelfth to one. fourth, very deep green; first pair with two waved streaks, fuld a reddish-white blotch at the posterior angle; sceond pair with a similar bloted at the posterior angle, and one or two towards the inner edge, the fringes white spotted with brown. Cateryillur, grey, feeds on the oak. Not common. Kent and Surrey.

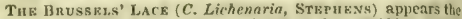
end of July. Wings one inch onc-fourth to five-twelfths; varied with green and ash-colour, sprinkled with dusky, with a com. mon very wavy and strongly isdented black streak belind the middle; the first pair has a somewhat incurved black streak near the base. Cuterpillar, greenish, or ash-colour, varied with yel. low, the sides with black spots; feeds on difterent kinds of lichen. Common. Cambridgeshire, Essex, and Surrey.

THв Winower (C. niduriu, STzрнекs) appears in June. Wings one inch one-third to one-half, white, sprinkled with black; first pair with three indented black streaks, with a black spot between the two last, on the hindermargin is a row of black crescents; second pair with a large central spot and two others on the inner margin. Scarce. Ilampshire.

TuE Smootu (C. feneraria, Stupuens) nppears the end of June or beginning of July. Wings one inch one-sixth to onethird, white, sprinkled with dusky; first pair with four equidistant dusky spots on the upjer edge, giving off an cqual number of indistinct streaks; secont pair with a dusky central dot, and an obscure cross strcak, and a waved black line on the hinder margin. Caterpillar feeds on the lichen omphalodes. Rare. Edinburgh, and Hampshire.

Tire Girnae ( $C$, cincturia, Curtrs) appears in May or June. Wings one inch one-half to two-thirds, ash-coloured, sprinkled with dusky, the hinder margin with an interrupted row of eres. cent-shaped spots, a band at the base, and several dusky spots on the disc, Local. Hampshire.

TuE Paintir ( $C$. pirtarin, StepuEvs) appears in the spring. Wings of the female one inch one-sixth, ash-coloured, with a row of distinct black dots on the jinder margin at the base of the fringe which is ash-coloured ; first pair with two pale waved streahe, having an interjacent round black spot; second pair with a waved streak also behind the middle; antenne reddish; body with a row of white spots on the back. Rare. Kent.

ALCIS (CuRTrs).

TrE Motrlen BEAUTY (A. repanduria, Cuntis) appcars the middle or end of July, in wouds and forests. Wings one inch 
three-fourths to two inclies, ashy-grey, clouded with clusky and grey, with a common waved black streak behind the middle, and towards the hinder maryin a white one bordered within with dusky; having on the margin itself a row of black erescentshatjed spots, an indistinct dusky streak towards the base of the first pair. Caterpiller, ashy-grey, with a dark line on the back, pale spots and dashes of black; feeds on poplar, birch, \&c. Commoa. Duriam, Yorkshire, Essex, and near London.

Tпв Motтled Canpet (A. destrigario, Curts) appears in July, in woods. Wings one inch cleven-twelfths, ashy-grey, very mach sprinkled and clouted with the same, with a common wary white streak, bordered fowarkly with ash-colour, near the hinder margin. Not common. Near London.

Tuk Wazt Carpet (A. mararia, Curtis). Wings one inch two-thirds to three-fourths, ashy-brown, with innumerable dots and obseure strcaks of a darker hue. Common. Scotland, and North of England.

The Great Canper ( $A$. conmersariu, Curts) appears in June, July, and August. Wings one Inch five-sixths to eleven-twelfths, ashy. krey, sprinkled with dusky, with a broad commnn blackish band, with two obtuse angles, the hinder margin reddish dusky. Rare. Dublin, near London, Kent, and Devonshire.

Tuk SILKLn CARpet (A. sericearia, Curtis) appears in July. Wings one inch five-sixths to two inches; silky-brown, or brickred, sprinkled with butf, having black streaks, and on the linder nugrin some black spots; fringes dusky, interrupted with buft. Rare. IIampshire.

Ths OAk Canpet (A. consortaria, Curts) appears the middle of June. Wings one inch five-sixths to two inches, ashy-frey, powdered with dusky, with indistinct indented darker streaks; same black conieal spots on the hinder margin; in the centre of the second pair a whitish ring or eye-like spot. Caterpiltur, dull brown grey, with bright stripes on the sides, and a spotted line on the back; feeds on poplar, willow, honeysuckle, \&c. Scarce, Essex, Kent, and Surrey.

THE OAK BEAUTy ( $A$. roboraria, Curts) appears the end of June. Wings of the male two inches one-sixth to one-fourth; female two inches onc-fourth to one-half, ashy-grey, sprinkled hith dusky dots; first pair with four somewhat interrupted wayed dusky streaks; sccomd pnir with three dusky streaks, the second strongly indented, and a central dusky crescent behind the first. Caterpilat, grey-brown, with as obscure line on the back, each segment with a dusky arch, and the thrce first with a yclinw spot; fceds on the oak and becch. Rather scarce. Kent, Essex, Sussex, and ILampshire.

THE Mint Beauty (A, piperilaria, StepHENS). A mere variety of $A$. roboraria.

The Willow BвлuтY (A. rhomboidaria, CURtis) appears the heginaing of Juy, in woody places and gardens. Wings one 
inch fire-sixths to eleven-twelfths, somewhat dusky, sprinkled and clouded with dusky, with three common black streaks, and a wayed white one towards the hiuder margin; on the margin itself a fine black line. Caterpillur yellowish-green, with a red. dish head, with a yellow streak and two blackish lines. Com. mon. Durham, Cheshire, Newcastle, Essex, Middlesex, Kent, and Surrey.

THE Deven Beauty (A. consubrinaria, Stepnens). Wingsoue inch five-twelfths to five-sixths, pate grey, sprinkled with dusky or rust-brown dots, with three common indented darker streaks and a white evanescent one towards the hinder margin. Searce. Devonshire, and Hampshire.

THE Welte B Bauty (A. fimbriaria, Stephens), Wings one inch one-half, ash-krey, with a hroad dusky border, in which is an indistinct streak of crescent-shaped white spots; first pair with a black dot in the centre. Rare. Suffolk.

\section{HEMEROPHLA (STRPHENS),}

The Waven UMBR: (H, abruptajia, STHPinss) appears in woody places, in May. Wings one inch onc-lialf to two-thirls pale bufr, slightly sprinkled, with a central black spot, and a common oblique dusky brown band towards the hinder margin, on which is an interrupted black line. Not scarce. Warwick. shire, Essex, and near London.

\section{BOARMIA (STEPHENS).}

Tuz Foun ANGLES (G. tetragonurin, STEPHENS) appears in the beginning of May. Wings one inch one-half to two-thirds, whitish ash, clouded with dusky, with very indistinct indented darker streaks, and adjoining the one behind the micdle of the first pair, two somewhat square dusky clouds. Searee. Kent.

The Pine Geat ( $B$. abieturita, Ochishninimen) appears in March and $A$ pril, in woods, Wings one inch one-half to two. thirels, grey, sprinkled with dusky dots, with the common in. dented darker streaks, and adjoining the one behind the middte, a somewhat square dusky pateh and some clouds; some blach spots emitted by a fine black line on the linder margin. Conl. mon. Lssex, Kent, Surrey, and Devonshirc.

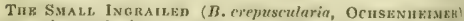
appears in woods, in May and Junc. Wings one inch one-half to seven-twelfths, whitish, slightly sprinkled with dusky, with the common indented dusky streaks which arise from equi-dis. tant black spots on the upper edipe, on the hinder margin a row of triangular darker spots. Not rare. Dumfriesslite, Cumberland, Warwickshire, and Essex.

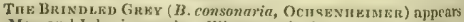
in May and July, in woods. Wings one inch one-third to seventwelfths, ashy, sprinkled with dusky, with the common streak dusky, very mucls interrupted, and very slightly waved, the one towards the hiuder margin white, inwardly ash-colour. Kare, kent. 
Thв BRINDLEd STRkAK ( $B$. strigularia, Stermuns) nppears in July. Wings one inch five-twelfths to one inch, asliy white, clouded with grey, sprinkled with dusky, with very indistinct common, slightly indented, duskyish streaks, and black suots on the hinder margin. Very rare. Kent.

TH Bhindeled White Spot ( $B$, extersaria, Ochsinueiarer) appears the beginning of June. Wings one incli one-third, ashy fiey, dotted and spotted with dusky, with indistinct darker streaks, and towards the hinder margin a pale or whitish waved btreak, near the middle of which, in the first pair, is a rounded white patch. Very rare. Middlesex, and Kent.

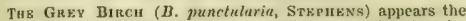
middle of May. Wings one inch one-twelth to one-fourth, ashy wivte, sprinkled with dusky, with three or four nearly common waved, arched, somewhat interrupted, dusky streaks, which are nore evanescent in the second pair, fringes whitish with dusky spots. Caterpillar, dusky grey brown, with five stripes and a whitish streak on each segment; fceds on the birch. Common. Durham, Warwickshire, Essex, Kent, and Surrey.

\section{HALIA (DUPONCAEL).}

TuE L. Motu (II. Vaturia, STEPHkNs) appears in June and July. Wings one inch one-twelfth to one-fourth, ash coloured; first pair with four black shortish unequal bands adjoining the second, and towards the upjer cdge a black V.like character; sccond pair with a small dusky spot in the middle. Caterpillar, freenisl, with black spots and a yellow line on the back and sides; feeds on the currant and gooseberry. Too common. Durham, Yorkshire, Cambridgeshire, Essex, and near London.

Tuв Black Vau (Vau nigraria, Hawortu) appears in July. Wings one inch one-twolfth to one-fourth, ashy black, with a black V-like mark in the middle towards the upperedpe; second pair paler, with a blackish margin. A varicty of II. Vuzaria. Very rare.

\section{NUMERIA (DUPONCHEL).}

The BarRen UмBri ( $N$. pulveraria, StErueNs) appears the end of April and beginning of June, in woods. Wings one inch onc-sixth to seven-twelfths, red, thickly powdered with the same; first pair with a brownisli red hatchet-shaped band in the micldle; second pair with an oblique indistinct line at the posterior angle. Cuterpillar, reddish brown, with bright streaks on each segment; feds on blackthorn and willow. Not common. Cumberland, Essex, and near London.

\section{CABERA (OCRSENIEIMER).}

THE WHite Wave (C. pusaria, OCnsEnנrmater) appears in May and August. Wings one inch one-sixth to onc-third, snow white, faintly speckled with pale dusky; flist pair with three 
equi-distant slightly waved lead-coloured streaks in the middle; second pair with two, agreciag with the two hinder streaks of the first pair. Caterpiller, slender pale greenish, with a series of red dots on the back; feeds on willow, alder, birch, \&c. Con. mon. Cheshire, Essex, audnear London.

THB Round WINO (C, rotunduria, STEPHENg) aplears in May and August. Wings one inch one-twelfth to one-fourth, snow. white, rounded, faintly sprinkled with pale dusky, with two common soncwhat waved leaden-coloured streaks in the mid. dle, of which the first in the first pair is double. Hather scarec. Kent, and Surrey.

The Twin Strife Wave (C. exunthemata, Strpnexs) apnears in woods, in May and August. Wings one inch one-twelth to nne-fourth, whitish, sprinkled with pale dusky; the first with three, and the sccond pair with two waved equi-distant dinsky yellowish streaks about the miclde; a distinet central black tot in each. Catergillar, reddish, with a pale streak on the sides; each segment with a white line on the margin; feeds on the birch. Common. Cumberland, Durham, Essex, and kent.

\section{EPIIYRA (DUPONCHEL).}

TuE LITTLE GrFek O (E. omicromuril, STEPHEN the end of Mry and end of Aueust, and becrinning of september. Wings eleven-twelfths to one inch one-twelftl, buff-white, hav. ing a black wavy streak before, and another strongly indented behind, the middle with an interjacent central black circle, and a row of minute black dots on the hinder margin. Cateryiliar Freen; fecis on the maple. Common. Essex, Surrey, and Kent.

Tus J3ref Mocua (E.penilulariu, Stephans) appears the end of May, ard end of $A$ ugust. Wings eleven-twelftis to one inch one-twelfth, hoary white, with two common streaks of black dots, with a conspicuous interjacent purplish circle. Cateryillar, pale Freenish, with the head and tail red; feeds on oak, birch, \&c. Pupu bright green. About London, in the woods.

THE DiNoy MochA (F, orbieularin, STrphens), Wings one inch one-twelfth to one-sixth, ash brown, with a purplish circle in the middle, having a common and slightly waved streak of black dots towards the liuder margin, and on the margin itsclf a low of minute black dots, Rare. Kent, Surrey, Sussex, and Ilampshire.

Tп: Mocнs SToN” (E. porat", STEPnENS) appears in wnods, the end of May and the end of August. Wings eleven-twelths of an inch to one inch one-sixth, reddish, thickly powdered with black, with a common central band, in which is a snow-white eyelet, havine a brown iris; two indistinct streaks of black dots, and a row of minute black dots on the markin. ('nterpiltar, brownish or pale yellowish, sometimes preen; feeds on the oak, bireh, \&e. Papa brown. Common. Fileshire, Essex, Kent, and Suney. 
This Erno Mocha Stonis (F, ocellaria, Srupinens). Doubtrul as a native.

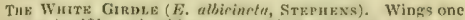
inch one-twelfth, each with a central white spot, and a common white streak near the hinder margin. Very rare. Surrey.

THE BUFF Argus ( 1 , punctarin, STrentws) appears in woody places, in May and in August. Wings one inch one-twelfth to one-sixth, redalish, sprinkled with very minute black dots, with a common central red band, in which in the sccond pair is a very white spot, and a series of black clots towards the finder marein. Cuterpillar brownish or yellowish-green, with streaks of reddish and yellow on the sides. Pupa redalish, with the tip yellowish. Common. Essex, and near London.

Tav: Trzme-tane Morus (F. trilinearia, Stapnexs). Wings she inch one-twelfth to one-sixth, red, with three common brown streaks, the first bufore the middle, curved, very slender and slightly waved; the second hand-like and longer; the third near the hinder markin, very slender, but much waved, and composed of very minute confluent dots. Rare. Essex, Kent, and Hampshire.

\section{BRADYEPETES (STEPHKNS).}

TuE Brond VerN ( $B$. amatrin, Srerutess) appears the end of June. Winfs one inch one-sixth to onc-thirs, pale ssliyyellow, powdered with grey, with the fringes and a common very oblique streak purplish-red, and a common wavy dusky streak towards the hister marizin. Cuterpiltar, reddish-brown, with dark shades and a pale line on the back; feets on lazcl, whitcthorn, \&c. Local. Warwickshirc, Essex, Herts, licnt, and Surrey.

\section{EPIONE (DUPONCHEL).}

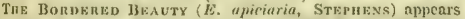
the ent of July. Wings urie inch one-twelf h to one-third, bright yellow, with minute reddish lines; frst paur with a right angled red brown streak hefore the middle, and a wavy dusky ane rising at the tip, with an interjaccnt spot of the same tint; the second streak is common, and the space from it to the fringe is ashy red. ('aterpillur, grey, with a white striak on the back, the sides with white spots and black dots; feeds on the willow, Not rare. Warwiekshire, Cunberland, Cambridgeslire, Essex, and Surrey.

Tue Vesper Beauty (E. respertaria, STEpuews) appears the middle of July. Wings one inch one-twelfth to one-sixth, pale yellow, with minute reddish lines; a dusky central spot; an arched dasky streak behind the middle, from which to the hin. der markin is ashy-red; the first pair also with an incurved reddish strcak nbove the base. Conterpillur, ashy-grey; feeds on the hazcl. Very rare. Yorkshire.

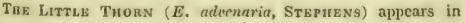


woods, the middle of June. Wings one inch to one inch onesixth, pale ash, sprinkled with dusky, with a pale dusky line on the margin, and the fringe ashy interrupted with dusky; first pair with two dusky streaks; second pair with onc, and a central blackish dot. Caterpillar, fore part grey-brown, with black dlots, the fifth sefment with two snow-white dots; feeds on the whortle-berry, Rare, Middlesex.

THE Dnuans ( $E$. delictaria, StepneNs). Sajd to be British on doubtful authority.

\section{EURYMENE (DUPONCAEL).}

The CnIP $A \times B$ (E. dotabruria, STEP IIENS) appears the end of June. Wings one inch one-sixth to five-twelfths, reddish or pale yellowish, with very slencler irregular ustulated lines; the base fand a blotch at the posterior angle reddish purple. Caterpillar, grecnish-brown, with a yellow and brown line on the sides; feeds on the onk, lime, \&e. Pupa brown. Scarce. Essex, Kent, Surrey, Warwickshire, Cambridgeshire, and Devonshirc.

\section{ASPILATES ('TrEITschK $\mathrm{x}$ ).}

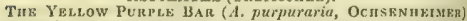
appears in August. Wings one inch one-sixtecuth, yellowish, with the margin and two bands on the first pair, purple. Caterpillar, green, with the back brown, with a pale line; feeds on the oak and black thorn. Very rare.

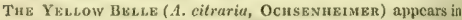
clover fields, in June and August. Wings one inch one-twelt to one-half, yellow, sprinkled with dusky ; first pair with two dusky streaks, with an interjacent spot towards the upper edge; second pair whitish, with a central spot and a waved streak behind the middle, dusky. Common. Kent, Herts, and Hants.

THF Straw Bersk (A. gilmaria, OcrisenflimsR) appears in grassy fields, in $A$ ugust. Wings one inch one-fourth to fivetwelfths, primrose yellow, freckled with dusky ; first pair with a very oblique streak, and central spot dusky; second jair with a central sjot towards the upper edge, and a cross strcak towards the hinder margin dusky. Caterpillus, greenish-ash, with red stripes, and a line on the back and sides; feeds on yarrow. Common. Kent.

Tin Grass Wave (A. respersaria, StepHens) appears the middle of June, on heatls. Wings one inch one-fourth to onehalf, ash.coloured, sprinkled with dusky ; first pair with thrce of four oblique equi-distant dusk $y$ streaks, and the second pair with three cross ones. Caterpillar, yellowish, with a brown stripe on the sides, with two ashy-grey dots on the back; fecds on the broom. Common. Near London, Surrey, and Ilampshirc.

\section{PIIASIANE (DUPONCHEL).}

The Lead Belle (Ch, plumburia, Stephins) appears the cnd 
of Junc. Wings one inch one-fourth to five-twelfths, pale lead colour, thickly sprinkled with dusky dots; first pair with three straight slanting equi-distant streaks, and a line at the tip dusky, cdiged with tawny; second pair whitish, with a cross central dusky streak. Common. Hertfordshire, Essex, Kent, and Surrey.

\section{LARENTIA (TREITSCHBR).}

TUE MALLow (L. cervinaria, OCHskNuhate) Rppears in woods, the middle of October. Wings one inch two-thirds to eleven-twelfths; first pair rusty brown, with an obscure central band, greyish at the margins, and a strongly waved white streak near the hinder margin; second pair pale reddish, with a darker streak behind the middle. Caterpillar, dull green, with the sides yellowish, and the segments margined with yellowish; feeds on the mallow. Kather searce. Durham, Essex, Kent, and Surrey.

TuE Goosw-joot ( $L$. chenopodiatu, StreukNs) appears in June and August. Wings one inch one-sixtecnth to one-third; first phir pale dusky red or tawny, with various indistinct waved streaks before the middle, a broad band in the centre, composed of several dusky streaks, behind this several indistinct darker strenks, with an oblique dusky line at the tip; second pair with two or three dusky cross streaks. Caterpillar, yellowish-green, with dark spots; feeds on grapes. Common. Durham, Yorkshire, Clieshire, Cambridgeshire, Iferts, Essex, Kent, and Surrey.

The Cindit Carpet (L. Gipunctaria, Ochsenhermbr) rppears in July. Wings one inch one-fourth to five-twelfths; first pair whitish-ash, waved with dusky, with an oblique dusky band in the middice, in which there is a black twin spot; second pair dusky-ash, with the streaks very indistinct. Caterpillar, ashygrey, with hairy lines on the back and sides; feeds on the trefoil, red-darnet grass, Rce. Common. Durham, Derbyshire, Horts, and Kent.

The Motrued Gniy ( $L$, multistrigaria, Stepuns) appcars in March. Wings one inch one-twelith to one-third, pale ashy, laving on the hinder margins a row of black twin dots; first pair with numerous streaks and bandlets of a decper hue, composed, as it were, of dusky spots and clouds; second pair whitish, with two darker evanescent streaks ou the middle. Rare. Essex, and Middlesex.

\section{CIDARIA (TREITSCHKR).}

TuE Twin-spot CARYeT (C. didymata, STEPHeNs) appears the end of July. Wings one inch one twelth to one-sixth, ashcoloured, clouded; first pair with interrupted brown and white streaks and bands, and towards the linder margin a brown twin spot. Common. Durham, Kent, Surrey, and Devonshire.

Tue Rupous Carpet ( $C$, munitatu, Strphens) appears the end of June. Wings one inch one-twelfth to onc-fourth, pale dusky, or whitish; first pair with a reddish tawny band at the base, and another in the middle; second pair with a tinge of yel. 
low and pale streaks. Caterpillur fecds on wormwoot. Not scarce. lifeshire, North of England, Essex, and Kent.

The Four-Band Carper ( $C$. unidentaria, Strpines) appears in June and Auglast. Wings cleven-twelfths to one inch one. twelfth, buff-red; first pair with a small black band at the basc, and another in the midille, towards the tip of the hinder margin an axe-shaped double black spot. Catrrpillor, dull green, with a line on the segments; feels on the bedstraw. Common. Cum. berland, Herts, Kent, and Surrey.

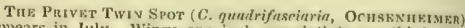
appears in July. Wings one inch one-sixth to one-third, pale dusky, with a tinke of tawny ; first pair with a small band at the base, and a black one in the midtle, having a black dot towaris the upper edge; towards the linder margin a faitut whitisl waved streak, in which is a double dusky spot, and on the margin itsulf is a somewhat square darker spot. Cuterpillur, pale dusky, with dult grey streaks, and a few black spots; feeds on the plaintain, \&c. Rare. Norfolk, Sufiolk, Herts, Kent, and Surrey.

Trk Red Twin Spot (C. ferrugaria, Ocrswintusr) appeats In May and August. Wings one inch to one inch one-twelft?, nsh-coloured; first pair with a reddish band at the base, and a broad waved one in the middle; towards the hinder margin a double black spot. Common. Durliam, Lssex, Duvonshire, and Hants.

Tнк Lunkr ( $C$. latenaria, Strpukss), WVings one inch one. twelfth to one-fourth, ash-eoloured, powdered with black, with waved streaks, and a row of twin black spots on the hinder masgins; a black dot trwards the upper edge on the first pair, ant] near the middle on the sccond pair. Common. Westrooreland.

Tuk Stripen Twix Spot (C. sulicaria, StwpreNs) appears the end of June. Wings onc inch one-twelfth, dusky-ash; first pair with various waved darker and paler streaks; a faint double dusky spot towards the hinder margin, and at the upper edge, near the tip, two somewhat square contizuous dull red spots; second pair pale-ash, with paler cross waved streaks. Caterpillar, feeds on the willow. Scaree. North of England.

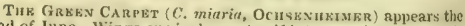
end of June. Wings one inch one-twelfth to one-sixth; first pair of a bright green, with two darker green bands end five black marginal spots; second dusky, with pale crossstreaks. Common. Durhan, Yorkshire, Essex, and near Londoa.

Tuk Olive Cariet ( $C$, olimaria, ocusenumime) apneary the end of August. Wings one inch one-twelfth to one-sixtli; first pair varied with olive green and white, with a clarker band at the base, and one in the middle, both margined with white; second pair ducky, with very indistinct streaks. Common. North of England, Essex, Kcnt, near London, and Ilasts.

Tun Super Ground (C. implicaria, Srepuens) appears the middle of June. Wings one inch one-fourth to five-twelfths, 
whitish ; first pair with two blackish intricate bands, and a somewhat eyelike spot towards the upper edge; seeond jair with dusky strcaks. Catrrpillar, dusky, with white luses on the sides; feels on the primrose. Common. Essex, and near London.

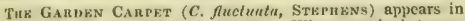
gardens the end of April until October. Wings one inch to one inch one-fourth, whitish ash; first pair with the base and two shortisl somewhat spuare bands on the upper edge dusky; second pair darker, with pale cross bircaks. Caterpillar, green, with black dots above; feeds on the horse-radish, cabbage, ke. Common. Durham, and near London.

Tue Rizвиn Canpet ( $C$. costovita, Stephens) Rppears in May and June, on hedges. Wings one irch one-twelfth, ash-coloured; first pair with the base, and two shortish somewhat oval bands on the upper edge dusky. A mere variety of $C$. fuctuata. Scarce.

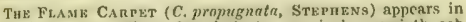
July, in woods. Wings tive-sixtlis to one incli one-sixth, ash colour; first pair with a red patch at the base, and a band in the mitlde, burdered on each side with a double dusky strcak. Common, Durham, Essex, Kent, llants, and Devonshire.

\section{IIARPALYCE (STEPHENS).}

The BArren Yelinw ( $H$, fulmata, STEPHLNS) appears the end of June. Wings eleven-twelfths to one inch one-twelfth; first pair tawny-yellow with a tawny.brown narrow band at the base, and a broad one in the middle, with a conical yellow spot at the tip; second pair whitish, with a tinge of yellow. Caterpillar, greenish, with a broad whitish line on the back; fecds on the rose. Common. Durham, Essex, and near London.

THE PUAPLB BAn ( $\boldsymbol{I}$. ocellalu, STEPIENS) appears the beginning of Junc, and end of Aurust. Wings one incls one-tweith to one-sixth, whitish; first pair with a rusky three-angled band at the base, and another in the midtle, broader, axe-slaped, and purjlish black, having the ordinary black spot towards the upper edge; between the hands some ashy clouds, and towards the hiuder margin a black twin spot; sceond pair with a black dot and the hinder margin darker. Catmpillor, brown, with a white line on the sides; teeds on the Galium sylvaticum. Common. Durham, Essex, Herts, Ikent, Surcy, Ilauts, and Devonshire.

Tuf Benstraiv Carpet (II. Gulinta, Strpines) appens on the sea-coast the begimning of June, and middle of August. Wings one inch onc-twelith to one-fourth, whitish; first pair with a disky streak at the base, an axe-shaped or irregularly indented dusky-brown band in the middle, the linder markin with dusky clouts. Caterpillar feeds on the Galium mollugo. Common. Dublin, Kent, and Devonshire.

THE ANGLED CArpet ( $I$, unilobata, Stbruens). Wings one inch one-sixth, ash coloured, slightly clouded; first pair with a small band at tic base, and a broad, dusky, one lobed, streaked 
one in the middle; the hinder margin darker, with a white evanescent streak of united white arches, in which is a double black spot; second pair pale dusky, with the ordinary streaks paler and evanescent. Rare. Yorkshire.

TuF Necklace CArpet (II. quadriamulula, Sterines). Wings one inch one-twelfth; first pair ashy-brown, with three double waved dusky streaks, and between these a narrow band of four ruund united white spots, bordered with blaek; the space in the midile ashy -brown, terminated by abrown wavy doublestreah, having the ordinary black spot towards the upper edge; behind these the wings whitish, but more or less ashy, with darker waves and clouds, and a small black spot on the upper edge near the tip. Scarce, Cambridgeshire, and Devonshire.

Thz Mournino Canret ( $\boldsymbol{H}$. tristata, Strpans) appears in June. Wings cleven-twelfths to one inch one-twelfth, white, with the common waved bands, streaks of dots, and border black. Caterpillar, yellow, with red-brown stripes; feeds on the Galium verum, Common. Yorkshire, and Devonshire.

TuE SAbIR CAnph (II. sublristata, Stepnens) appears in June, and in August. Wings one inch to one inch one-sixth, with baads and streaks dusky, ash-coloured, and white; the outer mar. gin of all with an indistinct ashy-brown streak of anited white arches. Caterpillar said to feed on Alchemilla vulgaris. Cora. mon. Durham, and Yorkshire.

The Woon Carpet ( $\boldsymbol{H}$. syluaticata, Strpnens) appears the berinning of July. Wings one inch one-fourth, with bands and streaks ashy, white, and dusky; the outer margin of all dusky, interrupted with a white syot. Rather local. Kent.

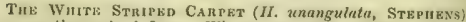
appears the end of Junc. Wings onc inch one-sixth to onefourth, ashy brown, with an obtuse angled band in the middle, anl the ordinary black spot towarts the upper edge; the outer margin of all ashy brown, with a streak of united white arches. Scarce. Kent, and Surrey.

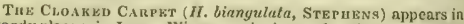
woody places, in June. Wings one inch one-fourth to one-third; first pair grecuish, with a broad darker band in the centre, hay. ing two angles followed by a white bandlet, fringes green, with a row of dusky spots; second pair ash-coloured, with various streaks. Rather scarce. Essex, IKent, and near London.

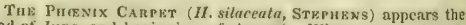
end of June, and beginning of August. Wings one inch onesixth to one-thirel; first pair flossy ash-coloured, with a dusky. brown band at the base, and another in the middle three-lobed, and markined on both sides with white. Caterpillar, bright green, with a dull line on the sides and a black one on the back, with some yellowish fereen spots underneath; feeds on the aspen. Not scarce. North of England, Essex, Middiesex, and Kent.

Tite Broken-BARred CArpet (1X. Corylata, Sternens) 
appears the middle of June. Wings one inch one-sixth to onefourth, sprinkled with dusky; first pair with a broad indented dusky hand at the basc, and anotlser in the middle, ereatly interrupted, and irregularly indented. Caterpiller, yeliowish green, with brownish-red spots on the back, and a whitisl line on the sides; feeds on blackthorn, lime, hazel, sc. Common. Fifeshire, North of England, Essex, Kent, and Surrey.

\section{POLYPIAASIA (STEPHENS).}

THR Wud CARPLT ( $P$. immanatu, STEPHeNs) appears the heginning of July, in woody places. Wings one incli one-sixth to one-fourth ; first pair ash-colonr, varicd with grey, with a band at the hase, and a second in the middle, outwardly strongly intented. Common. North of England, and Eissex.

THE PLAASANT ( $\boldsymbol{P}$. amanata, STEPHENS). Wings one inch one-sixth; first pair rather narrow, ashy-white, with the base black, and a very broal black band in the middle, inwardily indented, with the outer margin extending; secund pair whitish, Rare, Deyonshire.

The Maranen Canpet (P. mormaratu, STephens) appears in July and August. Wings one inch one-twelfth to one-fourth; first pair rusty-ash, slightly clouded with a white band in the mixldle, waved with black, with the outer margin extended, and strongly indented. Scarce. Norfolk, Essex, and Kent.

TII Juncton CARPET ( $\boldsymbol{l}^{\prime}$. concimutu, STEPIENS). Wings one inch one-fourth ; first pair ash.grey, clouded with black, with a whitish band in the middle, strongly inclented on its outer margin; second pair dusky, with a dark spot towards tlic base, and a pale streak bchind the middle, and a row of whitish spots towards the hinder margin. Rare. Isle of Arran.

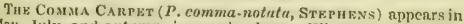
May, July, and nutumn, in woody places. Wings one inch one. twelfth to one-fourth, ashy browa ; first pair with a very broad tawny band in the millde, waved on its outer markin, with a black tot towards the upper edge; second pair dusky, with au indivtinet'dark spot, a strcak bchind the middle, and a row of pale spots behind the hinder margin. Rather scarce. Durlaam, Nor. folk, Essex, and near London.

THE UORNSEY BEAUTy ( $P$. centum-notutu, STEPHENs) appears the end of May, the cnd of July, and in aztumn. Wings one inclu to one inch one-fuurth, pale ash; first pair with an ash-coloured band in the middle, strongly indented on the outer margin; sccond pnir as in the preceding. Common. Jurham, Essex, and near London.

THe Lusu CARpex ( $P$. saturata, Stepuens) appears in July. Wiugs one inch one-sixth to one-fourth; first ptair somewhat ash coloured, with a paler band in the middle, strongly indented on its outer margin. Not scaree. Durham, and near Loncton,

The Degr Carpet ( $P$. perfuscatu, Sternens) appears in July, 
in woody places. Wings one inch to one inch one-fourth; first pair somewhat ash coloured, with a slightly indented black band at the basc, and another in the middle, strongly indented; second pair dusky. Scarce. Durham, Essex, Kent, and Surrey.

\section{STEGANOLOPHIA (STEPHENS).}

Tur Presnix (S. Prumata, Stepunss) appears in fardens the end of July. Wings one inch one-third to one-half ; filst pair ashy-grey, with a brownish-purple band at the base, having a white margin, another in the middle hroad and some what curved; second pair dusky, the frimges with dusky sposts. Caterpillar, Ereyish or greenish, with spots on the back, the legs red; feeds on currant, cim, poplar, blackthorn, \&c. Not scarce. Can. bridgeshirc, Essex, llerts, and Surrey.

\section{LAMPROPTERYX (STEPHENS).}

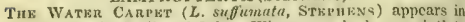
woorly places, in April and July. Wings one inch one-sisth to one-fourth ; first pair ash-coloured, very flossy, slinhtly clouled, with the base pitchy brown, and a central band of the same tint, with the outer marin extended, lobed, and stromgly and irregu. larly indented within, scarce. Essex and Herts.

Tux Pitch Brown ( $\boldsymbol{L}$, picento, Strpinss). Wings one inch one-third; first pair flossy, pitch brown, having a. darker hand in the centre, with a black spot in it, a white streak at the tip; second pair dusky, Rare. Durham.

Tнв RUst Brown ( $L$. badiata, SтrтивNs) appears in copses, in February and July. Wing's one inch one-twelth to one-sixth; first pair somewhat shining, rust-brown, with chocolate-brown at the base, and a white crescent in the middle; second pair pale, with dusky fringes. Caterpillar, dull kreess on the fore part, and reddish grey behind, with spots on the sides, feeds on the wild rose. Not scarce. Durham, Essex, and near London.

\section{ANTICleA (Stephins).}

Tiz Barberry Carpat (A. Bevberate, Strpings) appears the middle of June, Wings one inch one-twclfth to one-fourth; first pair reddish-ash, with three brown bands and a line at the tip. Caterpillar, varied with dusky, white, and red; feeds on the barberry. Rare. Berkslirc and near London.

THE FLAME (A. mulidata, STFIHEN July. Wings one inch to one inch one-sixth; first pair flame red, with a clusky baud at the base, and anotlicr on the outer margin; sccond pair ashy-brown, with obseure darker waves. Cirterpillar, grass green, with a clark line on the first and hinder segments; feeds on the Galium montanum and G. sylvaticum. Scarce. Essex, Kent, and Surrey.

The Roval Mantle (A. sinuata, Staphens) appears in July. 
Wings one inch one twelfth ; first pair pure white, with two narrow slightly curved black bands at the base; bchind the middle a shortish black band on the upper edge, and a sccond near it of a reddish hue, and bordered on both sides with white; the linder margin and fringes pale dusky; second pair white, with pale dusky margin and streaks. Scarce. I3erks, Irent, and Devon. slije.

Tae Strkamer (A. deributu, Stkpurns) appears the beginning of June. Winges one incli one-twelfth to one-sixth, pale red; first pair with thrce narrow deeply brown bandlets. ('uterpillur, green, with triangular spots, legs and tail brikht red; feeds on the wild rose. Rather scaree. Chesilire, Warwickshire, Esser, kent, and Surrey.

\section{ELECTRA (STEPIENS).}

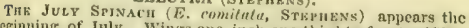
beginning of July. Wings one incli one-third to fyc-twelfths; first pair yellowish, elouded with tawny, with a double greyish waved streak at the base, a broad doubie grey band in the mid. the, having the ordinary black spots towards the unjer cdge, and a dusky line at the tip; second pair pale straw white; all the fringes white, spotted with bown. Cuterpillar, varied with green and dusky, with a yellowish line on the sides, with two dusky streaks on the head; feeds on the wild orach. Local. Yorkshire, Durham, and Middlesex.

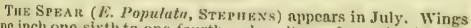
one inch onc-sixth to one-fourth, pale yellow; first pair with two bands, and hinder margin dusky. Caterpilltor, green, varied with yellow, with a red-brown spot on each segment; feeds on the poplar. Common. Scotland, Isle of Arrau, north of lingland,
and Cheshire.

TuE SPinacu (E. Spinachiatr, StrpHkNs) appears in July. Wings one inch one-third to onc-haif; first pair varied with yol. low and tawny, with three angular strcaks and an oblicue line at the tij tawny-brown; all the fringes pale, spotted with brown. caterpillne, green, with a pale line on the sides; fecds on the gooseliery and currant. I'npr pale green. Common. Essex, Herts, and Surrey.

Tur Cuevron (E. textata, Stepuens) appears in May and September. Wings one inch one-third to five-twelfths; first petir yellowish grey, with a broad band in tle middle, and a white streak at the tip, the fringes dusky; sscond pair whitish, with dusy fringes. Rather uncommon. Edinburgh, Durhan, CheShire, Essex, Midcllesex, and Devonshire.

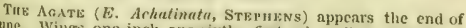
June. Wiugs one inch one-sixth; first pair yellow, with a red band in the midlle, and a rod spot at the tip, edged with white; second pair whitish. Caterpillus tecds on the poplar. Rare.
flemphire.

Tив Barmed Straw (E. Pyralutu, Sraphens) appears the 
end of July. Wings one inch one-sixth to five-twelfths, yellow: first pair with three augular tawny-brown streaks, a series of indistinet spots towards the hinder margin, and an oblique line at the tip. Cuterpillur, ycllowish-green, the segments edred with yellow; feeds on the whitethorn and bedstraw. Common. Dur. ham, Essex, and near London.

\section{CELMA (StEphens).}

The Stained AeATE ( $k$, imbutata, Stzrukns), Winesfivesixths of an inch to one imeh cne-twelfth, asloy-white; first pair with a brown streak at the base, and two somewhat confluent brown bands in the middle, the outer one edged with rose red. Not scarce. North of Eagland.

\section{ANAITIS (DUPONCHEL).}

Tur Slender Tremle BAR (A, plagiatu, Steprens). Winga one inch five-twelfths to three-fourths, greyish white; first pair whth two bands, each formed by three streaks in the middle; second pair paler, with an indistinct streak. Common. Oxford. shire, Nortolk, Essex, Kent, Surrey, and Devonshire. A. pra. formata is doubtiul as British.

\section{SCORIA (DUPONCHIL).}

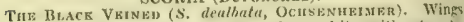
one inch two-thirds to three-fourtlis, above white, without spot, undemeath with the nervures black; first pair with a black spot in the miclalle, and a brown bandlet towards the linder margin. Rare. Kent,

\section{ABRAXAS (LEACI).}

TuE Pantukr (A. jumtaria, Stersiess). Wings one inch two-thirds to three-fourths, all whitish, with an oblique spot-like streak, a row of large spots at the inner edge, and the base of the first pair yellowish. Very rare. Somersetshire, and Devonshire.

Tute Chouned Magrie (A. Ulmatr, Leach) appears the middle of June. Wings one inch one-lialf to five-sixtlis, white; first pair dusky brown at the base, with a band, common to all the wings, behind the middle, composed of comlluent spots, dusky, yellow, and lead coloured, sliflitly sprinkled with silver; verious ruws of black dots on the body. Caferpillar, greenish blue, with numerous slender lines; head and tail black; feeds on the elm. Not scarce. Cumberlaud, and the North of England. Rare in Kent and Middlesex.

THE MAgPie (A. Grossularita, LxAcir) appears the ent of July. Wings one jnch one-third to two inches, white; first pair with the base and streak towards the hinder margin yellow, and six rows of round black spots, more or less confinent : second pair with a few scattered spots on the thise, a streak of the sante behind the middle, and a row on the hinder margin; body yel. 
low, with rows of black spots. Caterpillur, whitc, with a ycllow line on the sides, and various rows of black irrepular dots and spots; feeds on the currant, blackthorn, \&c., being liatched in the autumn, and living through the winter without feeding. very common every where in the three kingdoms.

\section{MELANIPPE (DUPONCHEL).}

The Srear Beauty (. M. hastatu, Stepuens) appears the beginning of June, Wings one inch one-thircl to one-half, white, all the margins black; first pair with two black spotted bands. Caterpillar, dusky brown, with wavy yellow lines on the sides; feeds on the birch. Scarce. Warwickshire, Essex, Kont, and Surrey.

\section{XERENE (TREITSCHXE).}

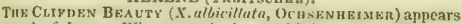
the end of June. Wings one inch onc-third to one-half, milkwhite, in the centre a black dot; first pair with a broad waved somewhat pitchy band at the hase, streaked with lead colour, a large black three-cornered spot on the upper edge near the tip; the marginal border varied with whitisls lead colonr and dusky; second pair with a dusky border, intertupted with whitish; behind a waved black double streak. Caterpillar, green, with the first and last segments with a brown line on the sides, the intermediate oncs with a brown crescent on the back; feeds on the rapplerry. Rare. Near london, Kent, and Norfolk.

The Chalk Carpet ( $X$, procellata, Ochsenumiar). Wings ne inch one-third to one-half, snow white; first pair, with the base, an abbreviated band on the upper edge, and the border dusky; the latter with a square white spot in the middde; second pair witl faint waved streaks, and a white one sometime's within a dark marginal border. Common. Essex, Iferts, and Kent.

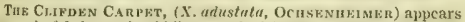
the end of July, and middle or end of August. Wings one inch to one one-twelfth, cream-coloured or whitish; first pair with the base tawny black, and a waved band of the same tint, towards the hinder markin; a row of double black spots on the margiu; second pair clouded or sprinkled with black, with streaks, and a band behind the middle, pale dusky, fringes white. Cuterpiller, green, with a white spot on the margin, with red dots; feeds on the spindle tree in chalky districts. Local. Essex, IIcrts, and Kent.

The Blue Borber (X. mliginata, OCus FNHEIMer) appears the end of June, and end of August. Wings three-fourtis to one inch one-twelfth, snow-white; first pair with the base and an interrupted band in the middle, varied with tawny and brown; the hinder margin of all wings lcad-coloured, witl a faint white streak. Cateryillar, grecn, with a pale line on the back, and a yellowish green one on the sides; feeds on the alder. Lucal. Durham, and Surrey.

Tur Plumben ( $X$, plumbata, SterneNs). Wings one inch to 
one one-sixth, lead-coloured or ashy white, the border lead-black, with a palc waved strcak; first pair with the base and central band darker. Scarce, Forfarshire.

\section{EUTIIALIA (STEPHiNS).}

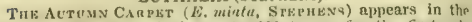
autuma. Wings one inch one-twolfth to one fourth; first pair whiti-li-green, with a darker band at the base, and another in the middle; second pair whitish, with a dusky spot hefore the mil. dle, and a common darker streak towards the hinder margin, and on the margiu itself a row of double black dots, Caterjitiur, pale green, with red dots; feeds on the bramble. Common. Durhan, Cambridgeshire, Essex, and near I,ondon.

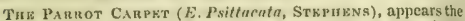
middle of October. Wings one iseh one-twelfth to oue-sixth: first pair reddish-grecn, with black waves, a darker band at the base, ond another in the midale; second pair dusky, with a central dot. Cnterpillur dull greeu. Not scarce, Durham, Can. bridgeshire, and near London.

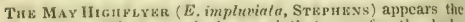
end of May. Wings one inch onc-sixth to one-fourth, dusky frey; first pair with the base and a broad waved band in the middle, whitisls; at the tips towards the upper edge two oblique deep black lines; second pair with olscure waved streaks to. wards the hinder margin. Calerpillor, reddish-brown, with th pale line on the sides, and two on the back; feeds on the birch and hazcl. Not scarce. Kent and Surrey.

\section{PHIBALAPTERYX (STEPILNS).}

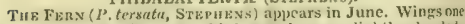
one-inch one-twelfth to one-third, grey-browu, slightly clouded: first pair with a very indistinct common broad band compuscl of evanescent blackish streaks, in which is a conspicuous black dot towards the upper edge; towards the hindermarpin is anindented whitiah line. Caterpillar, brown, with a grey line on the sider, and a pale one on the back, varicd with white; feeds on the Traveller's joy. Local. Herts, Kent, and Surrey.

The SMal, WAved UanRe ( $P$. vitalbata, StwpheNs) appears in May. Wings one inch one-twelfth to one-third; first pair redgrey, with a very dusky broad oblique fillet-like band from the midele of the inner edige to the tip; second pair black at the hase, but ferey towards the markin, with numerous dusky streaks. Local. Herts, Kent, and Surrey.

Tre Jury Hen Fuvin ( $P^{\prime}$. elutatu, Strentins) appears in July. Wings one inch one-twelfth to one-fourth; first mair grceil, or reddish, sprinkled, waved and clouded with black, with a whitish band belind the midrle; second pair ashy-browy. Common. North and South of England.

The Many Manked ( $\boldsymbol{P}^{3}$. polygrammata, Stepinans). Wingj 
one inch one-twelfth, of a yellowish white; first pair with nume. rous bands and two transverse streaks, dusky, with a black dot lowards the upper edge; seeond pair with dusky lines. Very
rare. Norfolk.

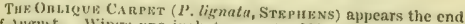
of August, Hings one inch to one-twelfth, palc grey, with karkerstreaks, hinder marrin with a row of double black spots; first pair with two oblique dusky bands, the first towards the upjer edge, ash colour, with a cleep black spot. Scarce. Cambridgeshire, Surrey, and Hants.

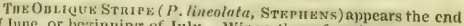
of June, or herinning of July. Wings three-fourths to eleventyclith of an inch, asliy lead-coloured; first pair with various darker streaks and two oblique bandlets in the middle, grey and margincd with white. Caterpitlar, with a broad yellow stripe on the sides, and hack reddish brown; feeds on the Galium verum. Common. Sussex, and Deyonshire.

THE NARRuw-Barrio Carput ( $P$. angustuta, Steprens) apnears the eud of Septomber. Wings eleven-twelfths of an inch, dusky frey, slizhtly clouded, with an indistinct band in the midelle, grathally enlarged towards the upper edge, near which is an eyelike spot; the hinder margin of all with indistinct dusky spots.
Rare. Middlesex.

\section{LOZOGRAMMA (STEPFENG).}

THE Buown SILvist LINEs (L. Metrurit, STEFHRNg) appcars the end of May, where fern abonuds. Wings one inch one-sixth to one-third, acute, rectlish, glossy; first pair with three oblique equi-distant whitisls streaks, inwardly bordered with dusky; seend pair whitish; all the fringes spotless. Coinmon. Essex, Herts, and Surrey.

\section{SCOTOSIA, (STEPHENS).}

THE DAтк UMBER (S. Nhambutu, STERHKNS) appears the end of Jay, or beginning of Junc. Wings one inch one-half to two. thirds, chestutut-bruwn, with obscure waved lines; first pair with an objique decy brown band in the middle, in which is a black angular spot towards the upper colge, Caterpiller, green, with a hrown line on the back, and the segments with yellow margins; teds on the buck thorn. Common. Essex, Ferts, and Kent.

THx Brown Scoli.op ( $S$, mitulatu, STEPILNS) appears in woods, the end of June. Wimp one inch one-sixtl to one-fourth; brown, indented with numcrous very obscure waved streaks, alternating with whitish ones, forming a band in the middle of the tirst pair, in which is a dusky spot towards the upper edge. Caterpillar, grey brown, with a white line on the back, and a yellow one on the sides; feeds on the buckthorn. Rather scarce. Essex, Mid-
dlesex, Kent, and Surrey.

The Dark Forkst (s. Spursarin, Stiphens) appears the end of Junc. Wings one inch, pale dusky, with alternate dark and 
whitish indistinct waved streaks, and black dots on the nervures; first pair nlso with a black central sjot and blackish clouds on the upper edge. Rare. New lorest, Hants.

\section{TRIPHOSA (STEPHENS).}

THK TISsue ( $T$. dubituta, STEPukNS) appears in woody places the middle of May, the midalle of July, and midelle of August. Wings one inch two-thircis to five-sixths, brown, shining; first pair having a tinge of purple, with a darker band in the middle, gencrally divided into two; second pair with obscure waved Jines, Caterpillitr, precn, with dusky lines, and pale streaks, the sides with a ycllow stripe; feeds on the buckthorn. Common. Edinburghshire, Durham, Warwickshire, Essex, Herts, Kent, and Surrey.

Tuz Cindeanua ( $T$. cinereata, Stzpurns) appears in Jaly. Wings one juch one-third to one haif, pale ash-colour, shining; first pair with a clusky hand at the base, and one in the middle, composed of two slender bandlets; towards the hinder margin is an interiupted white streak; sccond pale, without spots. Rare. Surrey.

THE Searce Tessue ( $T$. cerrinula, Stepuens) appears in April. Wings one isch two-thircs to five tenths, shining, grey; first pair with indistinct streaks or bandlets before the middle; then two narrow thicker bands, the outer one somewhat triangular, with an interjacent spot towards the upper edge; second pair with paler and darker streaks, and a spot in the centre. Cater. jillar, witl! pate stripes on the sictes, with green spots beneati; feeds on tlie barberry. Rare. Near London.

\section{CAMPTOGRAMMA (STEPHENS).}

TIE YELLOW SEELL ( $C$. bilimeatt, STH1'HENS) appears the end of Jume, and beginning of July. Wings one inch one-twelith to one-fourth; yellow, with numerous waved indistinet darker streaks; the first pair with a dusky double band in the middle, waved on its outer edige, and margined with white. Calcrpillar grcenish, sometimes with faint white streaks; feeds on the Lychnis dioica. Common. Scotland, Northumberland, Yorkshire, Cambridgeshire, Essex, and near London.

\section{EUCOSMIA (STEP HENB),}

TuE Scoliop SuELy. (K. unduluta, STEPuiss) appears the end of Iune, abcut woods. Wings one inch one-fourtis to five-twelftis, freyish, with numerous strongly waved dusky streaks edged with white. Caterpillar, feeds on the sallow. Scarce. lork. sbire, Warwickshire, Essex, Kent, and Surrey.

CHARISSA (CURTIS).

TIE DARE Arulet (Ch. obscurarit, STRPIENS) appears in July. Wings one inch one-fourth to five-twelfths; jowdered 
with black, with an eyclike spot in the middle, and an interrupted wack line on the hinder margins; first pair with two central streaks, and the second pair with onc, of a very deep black. 'aterpillar, violet brown, each segment with two white dots, the hinder ones with yellow stripes; feeds on the dewherry and southern-wood. Common. Devonshire and Ilampshire.

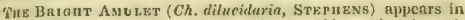
June. Wings one inch one-third to five-twelfths; asli-coloured, sprinkled with blackish-brown, with an eyclike spot in the niddie, behind which is a streak of blackish dots; the first pair, also, with a similar streak before the inlddle. Rare. Devonshire.

Tue Brown Anvert (Ch. mellatu, Cuntis) appears in August. Wings one inch one-fourth to one-third; ash-coloured, sprinkled with black dots; flrst pair with a darkcr waved streak before the middle, and a second behind with an interjacent black ring with a pale centre towards the upper edge, the cyclike spot and streak beyond the middle common to all the wings. Cummon. Durham, Kent, and Devonshire.

Tuk Black Awulkt (Ch, sevotinarin, Curtis). Wings one inch one-third; whitish, with numerous dusky dots, with a com. mon indented black streak betind the middle, and a central black ring, the hinder margin with a row of minute black dots; first pair have also a dusky waved strcak towards the base, Rare. Sussex.

Th: Oascure Awulet (Ch, operaria, CuRtis) appears the end of July. Wines one inch two thirds (1), ash coloured, varicgated with buff; first pnir with two dusky strcaks and an interjacent spot towards the upper edge; and near the hinder marfin a pale indeuted strcak; second pair has two pale streaks bcyond the middle, the inner one edged with black. Rare. Scotland, Fifeshire.

\section{PACHYCNEMIA (STEPRENS).}

Tuk Honse Chestrut (P. Ifippoeastanaria, Stepmevs) appears in April and July. Wings one inch one-fourth to onethird: first pair dark ash-coloured, with a sitvery hue, with an indistinct dusky curved streak towards the base, and a waved one behind the middle; a central dusky spot, and a row of black dots on the hinder margin; second pair whitish, with a reddish tinge, an indistinct strcak towaris the hinder margin, and on the margin a row of faint dots, Local. Essex, Kicnt, Surrey, and Hampshire.

\section{CHESTas (TratTsCHKE).}

Tue Strkak (C. Spurtiatu, Ocusenuminer) appears the end of Septeruber or beginning of Octuber. Wings one inch one. fourth to one-half; first pair grey, variously clouded with three dusky transverse patehes of the same colour, placed at the upper edge in tite middle, and at the base of the inner margin; towards the upper edge a pale streak reaching from the base to 
the tip, and towards the hinder margin an indistinct darker bandlet bordercd with white. Calerpillar, green or yellow, with a light stripe on the sides; feeds on the bioom, Local, Warwickshirc, and Surrey.

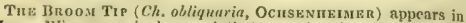
May. Wings one inch one-sixth to one-fourth; first pair red. dish grey, somewhat clouded, at the base a right angted evanes. cent dusky brown streak; and a second wavy band-like white streak near the hinder margin, which terminates in an oblique pitch-black line at the tip; on the hinder margin is a slenter black interrupted streak, in wardly bordered with whitish; second pair pale clusky, spotless. Scarce. Durham, Essex, and Surrey.

\section{THERA (STEPIBENS).}

THE IsLAND CARPeT ( $\boldsymbol{T}$. simulute, STEPHENs) appears the end of Junc. Wings one inch one-sixth; first pair ashy red, with the base reddish, and an angular central band of the same colour, with a dusky border, and having a dusky dot towards the upper edge; second pair reddish-white. Searce. Fifeshire, and Kent,

TuE Grey Carpkt ( $T$. veriatr, Strprens) appears in June, and in September. Wings five-sixths to one inch one-sixtl ; frst pair ashy-brown, with a dusky band at the base, and a sccond in the middle, angular and wavy near the upper edge, but thin and almost broken towards the inmer edge; between this and the hinder margin is a broad indistinct somewhat dusky streak, ontwardly pale; fringespotted with dusky; second pair pale dusky. Guterpillar, green, with a whitish line on the back and sides; feeds on various kinds of fur. Common. Cheshire, Herts, Essex, Middlesex, Kent, and Surrcy.

THю Овецик (T. fulvatn, StrpukNs). Wings one incli and a quarter; first pair ashy-grey, with a band at the base, and a sccond in the middle reddish. Scarce. North and middle of England.

Tne Junirer ( $\boldsymbol{T}$. Juniperata, Strpmens) appears in September. Wings one inch, ash-coloured; first pair with two dusky grey bands, and a dusky line at the tip. Caterpillur, grcen, with a whitish and reddish line: feeds on the juniper. Rare. Kent.

\section{OPORABIA (STEPHENS).}

Tue AUTum Boroble ( $O$. dilulata, STKPnens) appears in Octoher. Wings one inch one-sixth to eleven-twelfths, whitish ash ; first pair with various waved dusky strcalss placed in bands of two or three, and nearly equi-distant from cach other; second pair paler, with some waved lines tuwards the hinder margin. Caterpillar, dull green, with reddish spots and a yellowish line on the sides; fectis on the oak, elro, \&c. Common, Durhan, Cumberland, and Essex. 


\section{CHEIMATOBIA (STEPHENS).}

Tur Wintan ( $C$. Mulgaris, StermbNs) appears the end of November, and beginning of December. Wings of the male one inch one-tivelith to onc-sixth, ashy-brown; first pair witi various indistinct darker waved streaks, forming in the midale an indistinct trausverse band ; the hinder margin with some dusky spots at the base of the fringe. Caterpillar, pale green, with faint lines on the sides; polyphagous. Common. Durham, Essex, and Kent.

This EARL ( $C$, micaprarica, StzPneNs) appears the middle or end of Janunry. Wings of the male one inch one-twelfth to one-fourth, greyish brown; first pair witl a central band, terminated on each side with a deep colour, thinner towards the inocr margin. and the disc with a large black spot; the hinder margin of all with a row of dusky spots; second pair whitish, with a dusky spot in the middic, and an cvanescent streak towards the hinder marpin. I'emale whitish ash, with a central band, reddish margined with brown. Caterpiller, dull green, with white lines on the sicles, the segments with white edges; feeds on the wild plum. Rather scarec. North of England, and Essex.

\section{LOBOPHORA (STEPHENS),}

TH Honevsucis Ious ( $L$, polyeommatu, Curtis) appears in April. Wings pale grey brown; first pair with a central darker band, and an indented white line. Caterpillar, green, with dusky spots and a ycllowish line on the sides; feeds on the honeysuckle. Scarce, Kent.

TuE Tootu Strupio ( $L$. dentistriguta, Strmens) appears the middle of April, and in June. Wings one inch one-fourth to one third; first pair whitish or ash-colourcd, with about five very fidistinct dusky waved streaks, the outer one inwardly indented. Caterpillnr, brown, with the back dull green, and a yellowish line on the sicles; feeds on the honeysuckle. Scarce. Kent.

Tur Striren RrB ( $L$. mostastrigata, Cuitrs) appears in July. Hings one inch onc-third, ashy; first pair with about five dusky double equi-distant streaks on the upper edge; second pair with an obscure streak on the margin. Hare. Niear London.

Thв Devon LoBe ( $L$. rupestrata, STR PIENS) appeats in June. Wings one inch one-third; the first pair with five waved dusky streaks; the second pair with two dark dusky waved lincs near the nargin, fringes white. Rare. Devonslire.

Tne Yellow Brinni,e Ban ( $L$. viretata, Cunt1s) appears in June, Wings one inch onc-twelfth; first pair greenish, with bandlets and equi-distant streaks, varied with black and preenish, And, as it were, composed of black clouds and dots ; on the margin a row of minute square black spots; fringe ashy and brown; second pair ashy, spotless. Caterpillar, greenish-yellow, with redilish-brown spots on the back; feeds on the privet. Scarce, Norfolk, Essex, and Kent. 
Tue Sranpmisi ( $L$. hexupterata, Curtis) appears in June. Wings one inch one-twelfh to one-fourth; first pair varied with dusky and ash colour, with interrupted darker bands and streaks; the hase in the males with an orran resembling a wing. Caterpiltur, feeds on the beech in autumn. Common. Near Edinburgh, and in Kent.

Thi Small Skraprim ( $\boldsymbol{L}$. scritisata, Curtis) appears in June and $\Lambda$ ugust. Wings three-fourths to eleven-twelfths of aninch; first pair ashy-grey, clouded with two bands, and a streak towards the hinder margin whitish. Cuterpillar whittish green, with white stripes on the sides; feeds on the sallow. Scarce. Surrey, and llants.

\section{EUPITHECIA (CURTIS),}

The Benutivur. Pug (E. Linariata, Curtis) appears in $\Lambda$ ugust, Wings threc-fourths to five-sixths of an inch; first pair with dusky and red bands, the border ash-coloured, with an indistinet waved white streak; second pair dusky whit ish, with pale indistinct and darker streaks. Cuterpillar, Ereen, with dark spotson the back, and a dull line on the sides; feeds on the toad-flax. Scarce. Kent.

The Smale Brautiful Pue (E. pulchellata, Strpnens) Appears in July. Wings three-fourths to cleven-twelfths of an Inch; first pair ashy-white, clouded and streaked with red and dusky, with a dusky band in the middle. Rare. Kent, and Surrey.

Tue Grian Puo (E. rectangrelata, Stepuens) appcars the mid. dle and end of June. Wings two-thirds to tive-sixths of an inch, green, with streaks, clouds, and thrce posterior somewhat square confluent spots, ulusky; seeond pair somewhat similar, but without clouds. Common. Nortl of England, Essex, and near London.

TII Brass Pug (E. suberatu, STRPHeNs) appears in June. Wings two-thirds to three-fourths of an inch; first pair greed, with threesomewhat anguar black streaks; the borter slightiy clouded. Rare. Devonshire.

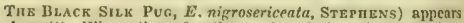
in June(?) Wings three fourthis to five-sixths, glossy or silky black, with a white waved streak near the hinder margin. Rare. Near London.

Tuk Satin Puo (E. sericeata, Sthpness). Wings pale silken brown, with a common waved streak near the hinder margin, and whitish fringes, Rare. Locality unknown.

TnE V. PUo (E. V. ata, Sterukss) appears in July. Wings two-thirds of an inch to five-sixths, green; first pair marked with a black $\mathrm{V}$ behind the middle. Kare. Essex, Kent, and Surrey.

TiE Doubl.F-Stured Pug (E. Strobilata, Stririns) appears in June amongst tirs. Wings two-thirds of an incli to three- 
fourths, greyish white, with a tinge of reddish, with two commen pectinnted dusky bands, and on the hinder margin an indistinct whitish indented line. Scaree. Surrey.

THв Ren-hArRed PUa (F. ruffascinta, StepuzNs) appears in March and April. Wings two-thirds of an inch, grey, clouded with black, with two reddish bands. Scarce, Near London and Deronshire.

THE Junipen Pug ( $E$. levigata, Sterfens) appcars in July or August. Wines three-fourths of an inch to five-sixths, ash. coloured, streaked and clouded with white and clusky. Cater. pillar very slender, smooth, green, with a darker line on the back, interrupted with red in the young state; the sides with two lines, slightly interrupted with whitish; the eyes aud hindermost segmeat reddish; feeds on the juniper. Searce, Kent.

The Motrun Pug (F. exiguta, Srepuens) appears the end of June. Wings three-fourths of an inch to five-sixths, whitish grcy, clouded with dusky, witli thrce dusky spots placed cross. ways, the fringes dingy, with darker spots. Cateryillar, dingy grech, with a line on the brek, and one on each side; feeds on the barberry. Not scarce. Fifeshire, Durham, and near London.

Tha Buff Puo (E.ocheatu, STephens). A dark variety of L. exiguata.

Tne Sifont Pvo (E. abbreviata, Custs) appears in June. Wings three-fourths of an inch; frst pair whitish, clouded with ash-colour, with various dusky streaks, and four deep black lines; second pair ash white, with the hinder margin clusky and somewhat streaked. Scarce. Yorkshire and Kent.

Tuk Grwy Pug ( $E$, singulnrintu, SrepuENs) appears in June. Wings eleven-twelftis of an inch; first pair aslay frey, slightly clouded and indistinctly waved, with a conspicuous black dot in the centre; second pair ashy, with a central dot and dusky margin, in whicls is a white waved evanescent streak. Rare. Kent.

TuB BRINDLED PUe ( $E$, nebulata, STEPHeNS) appears in woods in Jume. Wings five-sivths of an inch, ercy, sliphtly clouded with black; first pair with the ordinary black spot evanescent; second pair ashy, with two evaneseent streaks of minute black lines. Common. North of England and ncar London.

THE Sғeскци PUg (E. albipunctata, Stiruns) appears in woody copses in June. Wings five-sixths of an inch to one inch; fist pair dusky, with the central black dot, indistinct paler clouds, and a streak of white spots on the hinder margin, and a larger white spot on the upper edge before the streak; sccond pair simflar. Rather scarce. Ncar London.

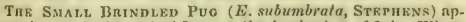
pears in woods the end of June or the beginning of July. Wings seven-twelfths of an inch to two-thircls, srey, with numerous decper clouds disposed, as it were, in streaks; sometinies a narrow band before the middic, composed of dusky streaks. Scarce. 
TuB Satar. BANDED Puo (E. subfasinta, Sternens) appears in June. Wings ten lines and a half; first pair rather narrow, dusky, with intermuted black lines, an indistinct pale band in the middle, and a pale indented streak cowards the hinder margin. Rare. Kent.

Tик Common puo ( $\boldsymbol{E}$. vulgata, Steтикуs) appears in gariens in June. Wings two-thirds of an inch to five-sixths, grey hrown, almost spotless, with a white waved streak at the hinder margis, inwardly marked with bown; sometimes a few obscure disky streaks on the disc. Common. Fifeshire, Cumberland, Cheshire, and near London.

Tne Brown Grey Puo (E. subfuscnta, Strpuens) appears in gardens in June, Wings three-fourths of an inch to five-sixths, dusky ash, with the hinder marrin clarker, in which is a pale waved indistinct and almost imperceptible streak; in the centre is the ordinary black dot. Not scarce. Near London.

THE ScARCw PUo ( $E$. innotutu, Steprr.ss) appears in gardens in June. Wings five-sixths of an inch, grey brown; first pair with two bands, composed of four black wared streaks; on the dise is the minute black dot; second pair paler. Rare. Kent.

TuE Wormwood Pue (I., Absinthiatn, StrpIExs) appears in gardens in Junc. Wings five-sixths of an inch, greg biown; first pair with black spots on the apper edge, and a large one on the disc; towards the hinder margin an interrupted waicd white streak; sccond pair with the posterior angle ash-coloured, with a minute white dot. Common. North of lingland and near London.

ThF Notri PUo ( $F$. notata, Strepnins) appears in June. Wings three-fourtis of an incl, srey brown; first pair with a round black dot in the centre; second pair with indistinct darker streaks. Scarce. Near London.

THE LoNn-Wingen Pvo (E. elnngatn, Stephens) appears in June in gardens. Wings eleven-twelfths of an inch to one ivch one-twelfth, rather long, of a uniform dusky tint, with black spots on the upper edge, and a large black spot in the middle towards the upper cdge; second pair palcr, with a smaller cen. tral spot. Rare. North of England.

Tuz Plain Pue (E. simpleiuta, Strorens) appears in July in lanes and gardens. Wings three-fourths of an inch to five-sixths, grey, rounded with various indistinct paler streaks, and a common indistinct border of a darker tint; in the centre of the dise is a minute dusky dot. Common. Kent.

Tux SuAle Grey Peg (E. pusillutu, Strphens) appears in June. Wings seven-twelfths of an inch to two-thirds, ash colourcd, with indistinct streaks, and the border darker; first pair with the ordinary black dot; second pair pubescent. Caterjillur, green, with pale lincs; teeds on the birch and juniper. Common. Kent.

The Lead-coloured Puo (E. plumbeolata, Stepnins) ap. 
pears the end of May and beginning of June. Wings seventwelfths of an inch to two-thirds, of a ieaden-ash, with jumerous indistinet darker and paler waves; the ordinary spot wanting. Common. Kent.

The TAwny Sruck (E. subfulvata, StErukns) appears the begiuning of August. Wings cleven-twelfths of an inch to one inch; first pair tawny, with the upper edge and hinder marigin dusky; towards the upper elge on the dise is a conspicuous black dot; second pair dusky. Rather searce. Near London, North of England, and Kent.

The Scotcu Pug (E. cognata, Strparns). Wings eleven. twelfths of an inch; first pair ash coloured, marbled with red ant white, with four louble and very much waved pale streaks, with black lines in the nervures, and a black rounded spot on the dise towards the upper cdge. Scarce. Fireshire and Mid Lothian.

THE Borphred Lme Speck (E. suceenturiata, Stephive) sppears in July. Wings eleven-twelfths of an inch to one inch, nshy-white, a little clouded; first pair with the upper edge and hinder nuargin dusky; on the disc towards the upper edge a conspicuous black spot. Caterpillar, chocolate brawn, with white stripes on the sides; fecds on the wormwood. Rather scarce. Kent, and Surrey.

Tns Crovnow Pue ( $\boldsymbol{C}$, piperitata, StrinkNs) appears the beginning of July. Wings three-fourths of an inch to five-sixths, whitish, powdered with ash-colour; first pair with the upper edge and hinder margin browaish-ash, a small black dot in the centre, Scarce. Surrey.

Tнe Lime Speck ( $E$. Centatreata, Strpirina) appears in June, in gariens. Wings two-thirds of an inch to tiversixths, white, clouded with black; first pair with the upper edge nearly uninterrupted black, having behind the middle a somcwhat three-cornered black spot, in which is a black cresecnt; second Jair white, with the inner and hinder margins and central dot more or less dusky. Caterpillar, green, with white spots; feels on the Centaurea scaviosa, \&c. Common. Durham, Essex, and near London.

TuE Naznow.WIngen Pug (E. angustuta, Sternens) appears the beginning of $\Lambda$ ugust. Wings two-thirds of an inch to thre-fourths, loog and narow, ash-colourcd; first pair with three oblique whitish bandlets, and the ordinary black spot; second pair with pale streaks. Commos. North of lingland, Jlerts, and Kent.

Tur Marnexd Puo (E. variegata, Stepmans) appears in Jume. Wings three-foutlis of an incli to five-sixtlis, whitish; first pair marbled with dusky streaks and bands; sceond pair with a black spot in the centre, and the hinder margin with dusky clouds, Kare. Kent.

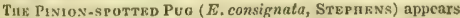
the end of Junc, or the beirinning of July. Wings threc-fourths of an inch to tive-sixtlis, glaucous green; first pair with double 
darker streaks, and liver-coloured spots on the upper edge, and a decp black crescent in the middle; second pair whitish-ash, with an ordinary central black spot. Rare. Yorkshire, Kent, and near London.

Tuz Netren Puo ( $E$. venosata, Strputens) appears the be. ginning of June. Wings five-sixtls of an inch to one inel, hoary ; frst pair with four uniting waved black or white streaks, Scarce, Near Loadon, and Kent.

\section{CLEOGENE (DUPONCHEL).}

THE Spotless YelLow ( $C l$, fincluria, Steprens). Wings one inch one-third to five-twelfths, yellow, spotless, the antenna black or dusky.

THK Spothess WHite ( $C$. niveate, Stephens). Wings cleventwclfths of an inch, snow-white, sjuotless; first pair dusky underneath. Rare. Scotland.

\section{MINOA (TREITgCHEE).}

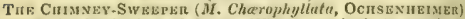
appears the beginning of June. Wings one inch to one inch one-sinth, deep sooty black, with the tips of first pair only white; antesure and body of the same colour. Caterpillar, duli greca; feeds on the Chrerophyllum sylvestre. Conmon. Durham, Middlesex, and Surrey.

The Drab Looper (M. Euphorbiata, Ocusanhermer, ap. pears in woods, the end of May. Wings three-fourths of an inch to five-sixths, brownish-ash, spotless and rounded; eyes black. Caterpillar, yellowish-green, dotted with white and black, with a clark line on the hack; feeds on the Euphorbia Cyparissias, Rather scarce. Essex, Kent, and Surrey.

\section{BAPTA (STEPHENS).}

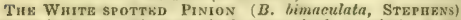
appears in Jume. Wings one inch to one inch one-sixth, snowwhite, with a black dot in the middle; first pair with two deep black spots on the upper edge. Local. Midulesex, and Kent.

Tue Clouden Silvzr (B. punctatu, Stephiss) appears in Junc. Wings one inch one-twelfth to one-third, snow-white, with a black central dot; first pair with a blotch on the inner margin, a band on the hinder margin near the tip, and a row of dots on the margin itself, all black; second pair with an evanes. cent dusky streak towards the hinder margin. Not common. Essex, and Kent.

\section{APLOCERA (STEPIENS).}

The Frbauany CAmpre (A, casintu, Stweness) appears the end of lebruary and in June. Wing's one inch one-fourth to one-half; first pair whitish, sprinklcd with bluish and dusky, 
with a broad indented dusky band in the middle, composed of several waved streaks, and dividing into two branches towards the upper edge, with a central black spot, near the hinder margin a. streak of white arches; second pair with the central spot and ane or two streaks dusky. Common. North of England, Cumberland, and Derbyshire.

TuE YвL,ow Bornen (A. Anvicinctula, StepuzNs) appears in June. Wings one inch one-third to one-lialf; first pair whitish, with blue dots, with a band mixed with dusky and yel. low, and forked towaris the ujper edpe, with a centrnl black spot, near the hincier margin a streak composed of white arches placed behind a fifth yellowish bandlet. Scarce. Cumberland.

\section{EMMELESIA (STEPHENS),}

Tar Sandy Cakrit ( $E$. dectoloratu, Stuphens) appears the end of June in wondy places. Wintrs one inch to one iuch onesixth; first pair brick red, with four strong equi-distant white streaks, the first near the base, the second in the middle, the third interrupted towards the hinder margin, and the third waved at the base of the fringe; second pair white, with a streak in the middle, and marginal border very pale and dusky. Common. Durham, Cumberland; Herts, Essex, and Middlesex.

TuE RIvulwr (F. ufimitutn, Stepinens) appears in June on shrubs. Wines one irich to oue inch one twelfth, of a tawny brown, somewhat streaked with dusky waves, with a conspichous white waved band behind the middle; sccond pair pale dusky, with a whitish band towards the hinder margin. Scarce. North of England, Essex, Herts, and Middlesex.

Tru: Sacl. Rivulet (E. Lurburin, Stemens) appears the end of Jume and beginning of July. Wings five-sixths of an inch to eleven-twelfths; first pair dasky, somewhat streaked with wayy white bands, with a narrow zig zag white strcak lehind the midtle; second pair more pale, with a darker margin. Com. mon, Fifeshire, Cheshire, Essex, and Middlesex.

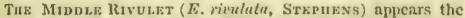
middle of June and in July. Wings two-thirds of au inch to three-fourths, brown; first pair with a whitish streak before the mithle, and a secoud composed of white arches towarts the hinder margin, behind the middle is a distinct waved white band, in which is a pale dusky streak; sceond pair dusky with a darker central dot, and an indistinct paier band bebind the middle. Caterpillar, greenish yellow, with reddish brown line; feeds on the Lamium purpureum. Scarce. North of England, llerts, and Surrey.

Tä Heatn Rrvuikt ( $E_{\text {. }}$ ericetata, Stepnens) appears in June. Wings seven-twelfths to two-thirds of an incb, ashywhite; first pair with the base, a ccntral band, and hinder mar. gin, on which is a slightly wared white streak, ashy-brown; second puir with whitish waved streaks towarts the hiuder margin. Common. Fifeshire and North of England. 
Tuk Wurte Border (E. Bindiata, StepheNs) appears in June. Wings three-fourths of an inch; first pair snow white, with an interrupted brown band in the centre, and the hinder margin pale brown, with a wayed white streak; second pais white at the base, with the hinder margin palc brown. Scarce, North of England.

Thx Grass Rivulat ( $E$. albulala, Stephens) appears in mendows the end of June and beginning of July and Augrast. Wings three-fourths of an inch to flve-sixths; first pair wit! narrow grey brown bands and ibdistinct somewhat waved white streaks, the linder margin reddisl-grey, with a waved whitish streak common to all the wing's; second pair pale dusky, with a narrow whitish band behind the middle. Common. North of lingland and Surrey.

ThE SMAll Blug Borner (E. trigonata, Stephens) appears in June and beginniag of August, about hedges, Wings three. fourths of an inch, white, the border ash-coloured, with a waved white streak; first pair with an ashy band at the base, on the mickle of the upjer edge a black triangular spot, and the very minute transverse band on the inner margin. Scarce. Cumberland, and Kent.

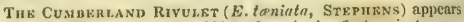
in July. Wings eleven-twelfths of an inch; first pair tawny. grey, with the base and the band in the middle dusky, and a rusty pateh on the upper edge; second pair dusky grey, with a pale streak. Rare. Cumberland.

The Single-Barren Rivelet ( $F$. anifasciata, Stephexs) appears in Jire and August. Wings five-sixths of an inch to clcren.twelfths; first pair krey-brown, with a brown band in the middle, towards the hinder margin a dusky twin spot, and a second at the tip; sccond pair dusky, with a faint central larker spot. Rare. Kent.

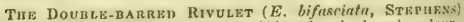
appears in June. Wings cleven-twelfths of an inch, ash-colour: first pair with two oblique contiguous bands, the outer one a little behind the middle and rather waved on the outward edpe, behind these, towards the upper edge, a brown twin syot, and a small one at the tip; second pair ashy, with a dark central dot. Rare.

Tue Least Carpet (G. vustient $a$, Stwplens) appears the end of June and beginning of July, in copses. Wings seven-twelflis of an inch to two-thirds, milk-white, with a black central dot; first pair with a waved or three lobed clusky band in the midrlle, and in fine specimens a pale dusky streak towards the hinder margin; second pair whitish, with ashy wares near the hase, and a row of minute dots on the hineler margin. Searec. Kent, and Surrey.

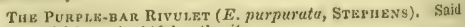
to be Britisb on doubtful authority. 
THE Waven CAnper ( $E$. syloutu, Stepuevs) appeurs in June, Hings eleven-twelfths to one inch, whitish, sprinkled with dusky dots and clonded; first pair with three narrow bands, and a streak of arches towards the hinder margin, reddish-grey; all the fringes ash-colourcd. Searce, Surrey.

Tuk SMa I.L Wuite WAVk (E. chndidutu, STEPHENs) appears the end of May and in Junc, in woods. Wings three-fourths of an inch to five-sixths, snow. white, having a central pale brown spot, with numerous common strongly waved inequi-distant grey streaks. Common. Essex, and ncar London.

Thi Smagh Yellow Wave (E. lutentu, Stephens) Rppears the end of May, in woody places. Wings three-fourths of an inch to five-sixths, deep ycllow, witik a dusky centrat spot towards the costa, and numerous common inequi-distant strongly waved reddish-ycllow streaks. Common. Fifeshire, Durham, Essex, Kent, and Surrey.

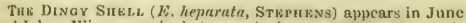
aud July. Wines one inch to one inch one-twelfth; first pair dall yellowish, with two pale dusky streaks behind the micklle, and the hinder margin dull brown; second pair dusky. C'uterpillar, grass-green, with two whitish stripes on the sides, and two white spots on each segment, head with black spots; fecis on the birch, (Betula adba). Scarce. Kent, and surrey.

\section{STRENIA (DUPONCHEL),}

Tar LAtriced IIEATH ( $S$, cluthratu, Srempuess) appears the end of May and middle of July. Wing's eleven-twelfths to one inch one-sixth; ycllowish with the nervures blunky, and about four inequi-distant broad waved streaks, occasionally mniting, the fringes with alternate brown and white square spots. Cider. pllar, bluish green, with a pale stripe on the sides spotted with black; feeds on trefoil. Common. Durham, Yorksliire, Essex, keat, Hertiordshire, and Surrey.

\section{VENILIA (DUPONCIEL).}

THE SPECKLED YкLLOW ( $V$. maculuria, STLPHNNS) appears in woody places the end of May. Wings one inch one-twelfth to one-fourth; tawny, with numerous scattered dusky spots. Cuterpillar, green, with a black line on the back, and a pale one on the sides; feeds on the arch-angel. Common. Warwickshire, Oxfordshire, and near the London.

TurPtion Spotren Yer Low, ( $V$.quadrimatulata, Strpinss) appears the end of $A$ pril and beginning of May. Wings one inch one-twelfth, sulphur colonred, the first pair with the upper edge sprinkled with brown at the base, and having four equi-rlistant black spots; second pair darker, spotiess. Very rare. Mlidulesex.

IIYIRIA (STESTENS).

THe PUTPLe-Bordene Gold ( $H$, aurorariu, Sterabis) ap- 
pears in June. Wings two-thirds of an inch to five-sixths; first pair of a rich golden yellow, on the upper edre an oblique band before the middle, ant a second towarts the hinder markin, purple; the second pair purple, witli a golden spot in the midrile, all the fringes of a deep golden yellow. ('aterpilar, kreyish, witli a pale line on the back and sides; feeds on the plantain. Common. Norfolk, Surrey, and Gloucesterslite.

\section{PTYCIIOPODA (STBPHRNB).}

Tin Suall Fan-pootzo Waye ( $P$, dilutariz, Stapmens) ap pears the end of August in hedges. Wings flve-sixths of an inch to cleven-twelfths; whitish-grey, with the hinder margin asb. coloured, ornamented with four or five alternate whitish or pale dusky streaks, and a row of black spots on the margin itself, with a waved dusky streak before the middle, and knother behind witl an interjacent central black dot. Common. Fifesliure, Durham, Essex, Kent, and Surrey.

Tuk BorDeren FAN-Footen WAve ( $P$. fimbriolala, Stepulars) appears in June. Wings cleven-twelfths of an inch; whitish, with a mimute decp brown central spot, a pale brown common central streak, and the hinder margin decp brown, with a waved vilite streak, fringes pale brown. Scarce. Near London.

Thu Pretty Fav-poot Wave ( $P$. decorariu, Stzpnkns) appears in June. Wings cleven-twelfths of an inch; ash-coloured, with a central dot and streak dusky, the hinder margin waved with dusky. Scarce. Near London.

Thz Salal. Dotran Wave ( $P$. lividata, Stepuens) appears the beginning of June. Wings three-fourtis of an inch to fivesixths; first pair ashy-white, sprinkled with minute dusky dots, with three small equi-clistant dots on the apper edge, from which arise three dusky streaks, towards the inncr margin three or fout transverse dusky spots, bordered with whitish, from which a whitikh waved stredk passes to the upper edge, beyond which the space is dusky; second pair very similar, all with a dusky spot in the centre, and a row of black twin spots on the hindef margin. Common. Fifeshire, Durham, and near London.

Tre Tremer 'Twis-spor ( $P$, trigeminuta, Sтвpumss) appears in June. Wings five-sixths of an inch, yellowish-white, with a central black dot; first pair with the base of the uyper edre and a band towards the hinder margin, composed of three double and somewhat confluent black spots; scound pair nearly spotles, with a slight dusky streak beluud the middle; at the hase of the fringe of all the wings a row of minute dusky dots. Ratict scarce, Kent.

TuF LACE Border ( $P$, ornatr, STspuses) appears in June and April. Wings one inch to one one-sixth, snow-white, a liftle clouded, with a central black dot, and an elegant waved borilet, composed of whitish-grey and pale dusky, united spots. Rare. Kent, Hants, and Devonshire.

TuE Muldein Wave ( $P$, incunata, Sternens) appears the 
end of June and in the nutumn. Wings one inch one-twelfth, whitish-grey, powdered with dusky, with a minute central dot, and obscure dusky waves, the first arched, sometimes wanting, and the second wavy behind the dot, and, as it were, composed of dots, a third towards the hinder margin, then a common very indistinct row of dusky round spots, and on the margin itsclf a row of triangular black dots. Not rare. Norfolk, Kent, and Deronshire.

the Large lace Bornun ( $P$. limbounbatet, Sternens) said to be British, on doubtful authority.

The Tooth Stmepd Wave ( $P$. contizuarin, Stupnens). Wings one inch onc-twelfth, whitish, slightly powdered with a central black dot, and about four common waved dusky streaks, the hinder margin dotted with black. Most probably a variety of $P$. incanata. Scarce. Norfolk and Kent.

Tuk Luscer Cream wave ( $P$. immutata, Stephens) apjears the end of June and beginning of July. Wings five-sixths of an inch to eleven-twejfths, cream-coloured, or whitish, with a cental black dot, and about tive common ncarly equi-distant yellowish streaks, the fringes often dotted with black. Scaree. Norfolk.

Tue Punple Ren Wars ( $P$.rubricata, Stephens), Wings eleven-twelfths of an inch, purplish-red, with three purplish brown streaks, fringes yellowish red. Rare. Yorkshire and Kent.

\section{ACIDALIA ('TrEitscher).}

Tue Dwarf Cream Wave ( $\lambda$. osseata, Stepntens) appears the end of June, on heliges. Wings three-fourths of an inch to fivesixths, whitish yellow, flossy, obscurely waved with a central tot, and a row of minute black dots on the hiuder margin. Comsmon. Kent and Surrey.

Tur Dotted Maroin (A. marginepunctatr, Stepuens). Wings five-sixths of an inch, buff coloured, with obscure waved streaks, a eentral dusky dot, and a row of black dots on the hinder margin. Perhajk a variety of $\nu$. osseuta. Local. Nlants.

The Sual, Dusty Wave (A. virgularia, Stephrens) appears in July, on hedges, woods, \&ec. Wings one-half of an inch to fre-sixths, longish, thickly powdered with ash-colour, the hinder nargin of all dusky, with small whitish clouds and minute black dots; the first pair with a slightly angular streak before the midrile, and a second, which is common, behind, Common. Durham, near London, Kent, and Devonshire.

Tak Satiny Wave (A. subsericenta, Stripiens) Rppears in Foody places, in June. Wings eleven-twelfths of an inch, of a silken white, witlı a greenish tinge, with five darker equi distant waved streaks, and without the ordiaary central spot. Scarce.
kent.

Tue Plain Wave ( $A$, inornata, Sternens) nppears in woody 
places, the cnd of June and begioning of July. Wings one inch one-sixth, pale grey-brown; lirst pair with three equai-distant darker evanescent streaks, the last of which is shightly waved towaris the upper edge, the fringes spotless. Not rare. Kent.

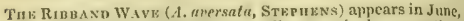
July, and beginnisg of september. Wings one inch one-sixtls to one-fourth, ash-coloured, witlı remote dasky dots, and a dark cen. tral dot, beyond which is a broad dusky slightly waved band, an interrupted pale waved marcinal streak, and at the base of the fringes some black spots; the first pair also with a faint streak towards the base. Common. Cheshire, Essex, and near London.

Tie Vamiate Rrabann Wave (A, remutatn, Staphens) appears in woods; in Junc and Scptember. Wings one inch one. sixth to thrce-fourths, ashy, with a central black dot; first peir with three equi-distant slightly waved dusky streaks, of which the two last, and another at the base of the fringes, composed of black dots, are common to the sccond pair. Common. Edinburgh, Durham, Cheshire, and Essex.

TrE DrNgy WAvE (A. fuliginate, StePrs sa) appears in June. Wings one inch one-half to one-sixth, of a smoky-browr, with an indistinct dark streak behind the middle of the first pair. Hare. Near London.

Tuғ Sмоку WAv: (A, fumnta. DazE?) appears in June, Wines one inch oue-twelfth to one-sixth, ashy, very thickly sprinkled with dusky dots, with three or four very indistinct dusky streaks, and the hinder margin sputless. Scarce. Scotlaud, Cumberiand, Westmorcland, and Devonshire.

TuE PAin CrвAM WAvE (A. lactata, Sternens, ) appears the end of May and middle of June. Wings one inch one-tweltih to one-sixth, whitish, with a streak near the base of the first pair, $\mathrm{n}$ waved onc in the middle, and a third towards the hinder mas. gin, common to all the wings; the margin itself sometimes with a jow of very minute black spots. Common. Lssex, and near London.

Tue Creas Why (A. fosluctata, Strpinens). Wings one inch to one inch one-twelfth, cream white, sprinkled with minute dusky dots, with four dark waved streaks, disposed in pairs, the two first before the middle, and the other two behind. Contmon. Durham, and near London.

\section{PCFCILOPHASIA (StBPHBNS).}

Trл Clounio Bunbea ( $\boldsymbol{P}$. marginata, StepHens) appears in Mry, July, and August. Wings one inch to ore inch one. twelfth, white; the upper edre of the first pair black, interrupted in the midrle with white; in the centre of the wings a common interrupted black band; on the hinder margin a broad waved black border' the fringes black. Common. North of England, Yorkshire, Norfolk, Essex, and near London. 
TIMANDRA (DUPONCREL).

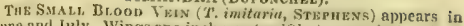
June and July. Wings one inch une.twelfth, to one-sixth, with a curved dusky streak before the middle of the first pair, and two behind, common to all the wings; the fringes reddish. Common. Cheshire, Essex, Kent, Surrey, and Hants.

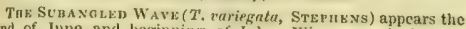
end of June and beginniog of July. Wiugs one inch onetwelfth to onc-sixth, whitish, sprinkled with ash-colour; the first pair with a very indistinct streak towards the base: then, common to all the wings, an oblique dusky band behind the middle, and an indented streak, and near the hinder margin, and on the margin itself, a very sleader and somewhat interrupted line. Rare. Kent.

THE New Fonkst Wave ( $T$, emutoriu, Steptens) appears in July. Wings one inch, pale yellowish red, with an obscure central band, a black dot on the disc, and a row of black dots on the margin, liare. New Forest, IIants,

Tur Rosy IVAve ( $T$. subroseafa, Strpirans) appears the end of July. Wings one inch, rosy-white, with numerous very minute dusky dots, with an oblique dusky rather short streak, passing from the tip to the middle of the inner margin of the first pair, to the inner eclge of the second pair; behind this on the first pair are about five minute black dets; the second pair with ope or more streaks towards the margin. Rare. Norfolk, llants.

\section{MaCARIA (Curtis).}

Tine PEAcock (M. Notuta, CyuTs) appears the end of May and beginning of Jume. Wings one inclione-twelfth to one fourth, whitish, sprinkled with dusky, with three dusky streaks; the first pair with three or four reddish spots on the upper edge; the notch of the hinder margin with a red-brown creseent; second pair acately angied, with a black central dot. Caterpillar, green, with the sides brownish-ycllow; feeds on the willow, oak, \&ce. Scarce. Cumberland, Kient, and Surrey.

The Sinzp Anglem Pbacock (MI. alternata, Stronges) appears in June, Wings one inch onc-twelfth to one-sixth, ashcoloured, sprinkled with dusky, with ashy streaks ; first pair with four black spots on the upper edge, and a black crescent at the tip; second pair somewhat tailed, with a conspicuous central dot. Rare, Kent, and Surrey.

The Slender Stripla Rupous ( $M$. subrufata, Staphens). Wings one inch one-fourtb, reddish, with slender darker streaks. Very rare. Locality unknown.

Tne Tawney Barnen Anele (, H. liturata, Curtes) appears in Junc and August. Wiugs one inch one-fourth to tive-twelfths, ashy, with three common dusky streaks at the base, arising from spots on the upper edge, behind which is a common yellowish band. Common. Cumberland, Kent, and IIampshire. 
TuF DINgy ANeurd (M. prantomata, Curtis). Wings one inch une-fourth, whitish, thickly covered with dusky dots, with three very indistinet streaks, the border darker. Ilare. Locality unknown.

TuF Wurt Srot (M. unijunctata, StepHexs). Wings one inch one third, reddish, indented, with three indistinct streaks, and a white spot towards the tip. Rare. Locality unknown.

\section{ANIA (STEPHBNS).}

The Bonderp Cnequer (A. limbata, Stapinexs). Wings one incli one-twelfth, pale red, waved with rust-brown, with a broad rusty-brown border. Rare. Scotland.

The Sual. Scos.lop (A. emarginata, Certis) appears the end of July. Wings five-sixtlis to eleven-twelfths, ycllowish, with a centrat black dot, and three dusky lines. Caterpillar, dull yellow, with a brown line on the back; feeds on the bind weed, Common. Essex, and near London.

\section{ENNOMOS (TrEITSCHR}

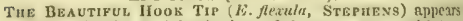
the middle of July, and beginoing of $\Lambda$ ugust, grey, witli two pale aneular streaks, bordcred with dusky, and two interjacent spots. Cuterpillar, greenish, with the ncek, protuberance on the back, tail, head, and legs reddish; feeds on lichens. Scarce. Essex and Sturey.

\section{PLATYPTERICIDIE.}

\section{PLATYPTERYX (LABPEYRES).}

Tue Scalzop Ilook Tip ( $\boldsymbol{P}$. lacertula, STHP HeNs) appears in May. Wings one incls one-fourth to one thirel, grey and wary, as if croded, with two rusty streaks, and a point between them: second pair white, with a yellow border; Caterpillar fceds on the birch in September. Near London.

THE Linkless Hook TiP, ( $P$. cultraria, Stephens), Very stmilar to the preceding, but the wings without any cross-lines. Near London.

\section{DREPANA (LASPEYRES).}

THe PeEble IIOOK IIP ( $D$. fateutaria, Lencur) appears in June. Wings one inch one-third, glaucous grecu, with nume. rous iron-grey wavings; first pair hooked with a band, grey wavings, and a dusky point. Rare. Yorkshire, and ner

London.
THE OAK IIoOK TIP (D. hamula, SrepHFNs) appears in onk

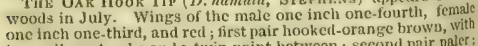
two yellow streaks and a twin point between; second prir paler; in the female all the wings paler. Cateryillar feeds on the oak. Rather scarce. Kent, and near London. 
TuE Bnown Hook Tip (Dr. unfula, Strpiens). Near London.

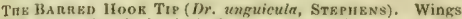
one inch one-fourth, hooked, dlusky yellow, with two curved streaks, rather thicker towards the edge, and between these the colour of a deeper tiat. Near London.

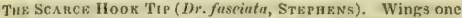
iuch five-twelfths, liooked, dusky yellowish, with two slanting dukky streaks, curved, and thicker towards the edge; second pair with a smalk streak, Ikare. Locality unknown.

\section{CILIX (LEACH).}

Tri Goost Ego (C. compressa, Licacm) appears in hedges in May and August. Wings of the male eleven-twelftis of an inch; female one inch one-twelfth; snow whitc, with a shortish oval brown band, in whicls is a sleader silvery letter-like mark; the second pair white, with a dusky margin and paler fringe. (' $u$ terpillur duskv, with four syines before and two behind, and a sharp tail. Pupa brown before, blue behind. Common. Near London.

\section{PYRALIDA (LRACH).}

IIYPENA (SCHRANE).

THR SNout ( $H$. probosridulis, OchsexuEIMER) "appears the fid of June and beginning of August; common airout hedges. Wings two inches; first pair with an incurved strenk before the mildle, then a narrow obligue band in the centre, but often an. teriorly indeterminate, between this and the binder markin a re. janded strenk, which does not reach the upper edge. but is often externally directed towards it by from three to six whitish dots, lastly, an oblique dusky liue at the tip; second pair dusky, all the fringes ashy-grey."

Tuk Pinion Snout (II. obesalis, Ocusanhumir), "Very similar to, but distinct from, the fureguing, for it is smaller with loner palpi. Wings one inch one-sixth, acute, slightly retuse, ashy frey ; first pair with a black spot from the base to the middie, but becoming thin towards the base. Very unfrequent."

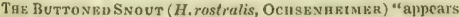
the end of June, on hedges. Wings one inch one-sixth, acute, sonzewhat retuse, pale grey; first pair from the base to the nitklle of a darker hue, with spots, and a line usually raised in the niddle ; sccond pair dusk $y$. Not common."

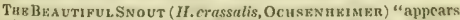
the beginning of June, amongst woods, in Kent. Wings one jnel one-fourth, acute, slightly retuse, white; first pair with a large pitch-black hatchet-shaped patch, extending from the lase $($ ) nearly the juner margin, between this and the hinder margin a slightly bent streak, composed of black dots, and a broad black line at the tip; second pair dusky. Very uncommon." 


\section{POLYPOGON (SCHRANE).}

Thв CUllender ( $P$. cribrulis, Stepuwns).

Tut Common FAN-Font (I'. barbulis, STrptens) "appears the middle of May and beginning of July on hedges. Wings one inch one-fourth; first pair more or less ashy. frey, with a streak unangulated on its outer edge before, and a very similar one behind the middle, between the latter and the hincler margin a third oblique, all of a darker tint; second pair behind the middse and towards the upper edge palcr, with two indistinct darker streaks beyond the midile, and a very slender dark and common one on the hinder margin."

Tre Chay Fan-goot ( $P$. derinalis, Strpukns). "Wings one inch one-sixth, all reddish, a darker streak on the first pair, slightly incurved before, and another much incurved and com. mon bchind the middle; in all the wings $a$ darker crescent in the middle, and a very slender streak on the hinder margin ; antenno bristle-shaped. Uncommon. Kent."

TIE FA. HOOT ( $P$.tarsicrinalis, STEPIXNS) "frequents wondy places. Wings one inch one-sixth to one-fourth, dill reddish, the two anterior strcaks of the first pair as in the preceding, but the second more waved, the third streak more rightly oblique towards the hinder margin; the second pair palc dusky, with a darker posterior streak, whitish on the outer cdge; the male differs greatly from the female, in having the fore legs singularly and thickly banded."

TuE SuAtL FAN-Foot ( $\boldsymbol{P}$. nemoralis, Strphens). "Very similar to the foregoing, but rather smaller. Wings one inch onetwelfth to one-sixth, with three streaks and a crescent brown, the posterior streak rather beat, and drawn to the tip. In wondy places not common."

The Oleve Crescent (P. pmortualis, Steruens), "Wings one inch, dusky yellow, with two streaks and a crescent in the midde yellowish; in figure, size, and colour, it resembles the Clay. Fan-foot $(\boldsymbol{P}$. derivalis $)$."

MADOPA (STRPRENS).

Tue Lesser Bell(M. Salicalis, StrpueNs) "appears the midtdle of June, and frequents plantations of birch. Wings one inch rleven-twelfths, ashy-lead, with three oblique equally distributed streaks, the third waved and reaching to the tip, the second in a right direction, and not waved; the crescent is absent. Fery unfrequent."

\section{CLEDEOBIA (STRRHRNS).}

Tire Sual. Snour (C. angystalis, Strerens) "appents the mildle of July. Wings one inch, dark tawny, with an oblique line at the tip of the first pair, with the upper edge prettily sprinkled through the hand with numerous white dots turned outwardly, and disposed in pairs, a darker band in the middle 
oftentimes unsolid towards the upper edpe, with a common dusky spot; second pair dusky, fringes red, all the fringes darker. Coombe Wood."

Tuz WHite line SNout ( $C$, ulbistrigalis, StepmeNs), "Wings five-sixths of an inch, rather dusky, with a broad band having i dusky spot, and indistinctly termianted with white. Very uncommon."

Taz Rib-straped Snout ( $C$. cosla-strigalis, Stepinens).

The WAVED (C. undulalis, Stephens).

THE DOUBLE-STRIYED (C. bistrigalis, STEPHENS).

\section{AGLOSSA (LATREILLE)}

THE TABBY (Ag.pinguisulis, LATriIJLE) "appears the end of July. Wings one inch one-half, rather longish, ashy-grey, with an oily flossimess, with a spot at the base, and two contiguous wavy, brown streaks a little beforc the midule, and between these a paler colour; between these streaks and the hinder margir a third streak wavy, brown, terminated by \& paler colour, and rather double (duplex) in a certain position, and between the second and third in the middle of the wing, with the colour in some joints of view darker, and a common brown spot towards the sccond streak and the upper edge; second pair pale dusky, indistinctly clouded, doubly streaked belind the middle; the fringes of all the wings brown. Not common." Near London.

THe SMale TABву (Ag. capreolatus, Stepuens) "appears the end of July. Wings five-sixths of an Inch to one inch eleven. twelfths; first pair rather narrow, blunt, dark purplish, but paler in some positions towards the hinder marpin, a wavy strenk before the middle, and another repanded near the hinder margin, pale and indistinct; second pair duskyish or whitish." Near London.

The Tва TAвnq ( $A g$. dimidiatus, Sternens). Supposed to be British on doubtful authority.

\section{PYRALIS (STRPHENS).}

The Mral Motí (Py. furinulis, II U BNm R) "appears the end of August. Wings one inch to one inch one-sixth, dusk $y$ brown, with a very broad wavy sea green band in the middle, margined on both sides with white; second pair with two wavy white streaks in the middle, having a dark ir-coloured space between them; on the hinder margin ottentimes an incomplete row of black spots, larger towards the posterior angle." Near London.

The Scarch Mral Moth (Py. marginatus, Steruexs). "Wings brownish, with two brown bands bordered with white, the first towards the bese, and the posterior marginal."

THE Double Stripkd ( $P$. glaucinalis, Stephens) "appcars the begioning of August. Wings one inch, the streaks of the frst pair yellowish and thicker towards the upper edge, the first L 2 
situated before, and the second behind the middle; between the streaks many yellowish small dots on the upper edge; the second pair with a somewhat incurved streak before, and another waved behiad the middle, both white; on hediges. Not common." Near London.

\section{AGROTERA (SCRRANK ?).}

The Goln Fringe ( $A$. custalis, Stramens) "pupcars the beginning of July on hedges, but not common. Wings two-thirets of an inch to three-fourths, all purplish ; first pair with a larke patch on the upper edke before, and another bchind the nill. dle, trapeziform, and gold-coloured, from which, in certain positions, run two yellowish imperfect streaks, evanescent and very indistnet; second pair with two rery similar but more conspicuous strcaks, the fringes very ample." Near London.

\section{ASOPIA (TREITSCnKE.)}

TuE Rosy Flounced (1. flemenlis, STrumens) "appears the end of June, freguent in Coombe wood. Wings three-fourths of an inch, all purplish-erey, with two anterior streaks; second pair whitish, with a band in the midlle." Near London.

\section{SIMAËTHIS (LEACg).}

THE NeTtLE TAP (S. Fubriciann, STEPHENs) "frequents banks and hedpes. Wings half an inch; forst pair blackish, with a pair of whitish distinct spots, budy small." Ncar London.

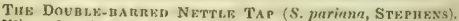
"Wings five lines to five and a half, dusky, with two decp black streaks and a brown margin. Found in gardens." Near Lon. don.

Tun Early Neftle Tap (S. Iutosu, Strfuens) "appears the befinning of March. Wiugs five-twelfths of an inch: first pait clull hrick red, or rather ycllowish, without spots, with a small number of black and white dots on the upper edge; seeond pair pitch-coloured. Perhaps a mere spring or autumn varicty of the preceding." Near London.

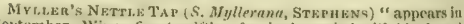
Scptember. Wings five-twolfths of an inch, varied with black and ashy-grey, and dotted with silvery, with an ashy-brown narginal streak towards the hinder margin. Found on nettles, but not common." Near London.

Tir Narrow Shever Dotred (S. menctuosa, Stmpiess). "Wings tive-sixths of an inch; first pnir rather dusky and some. what wedge-shaped, obliquely cut at the tip, with some few very minute silvery dots. Perhays a varicty of the foregoing, for its wings are narrower, with far fewer silvery spots. Very rare."

ENNYCIIA (TREITSCHEE),

THE Wute Sror (E. oetomucululu, SterHexs) "appears the 
end of May in woody places, and again in August. Wings five. sixths of an inch, all black on both surfaces, with a larre romit white patch before, and another behind the miclde; and afterwards between these spots in the first pair a white dot, fringes black, but white at the tip towards the pusterior angle. Not common." Near London.

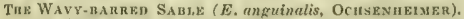
"Occurs about woods in chalky districts. Wings half an inch to seven-twelfths, all deep black, with a common wavy very white and distinct streak rather behind the middle. Uncommon." Near London.

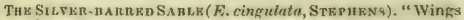
two-thirds of an inch, all black, with a very white, somewhat common but oblique streak, and situated rather behind the middle; second pair brownish. Not frenuent."

THE Frouvero (E. fascialis, Sterstens). "Wings two-thiris of an inch, ashy-red, with an oblique band at the base, a spot on the upper edre in the middle, and near the hinder margin a wared or fillet-like band, red; sccond pair reddish white, with a dull red border. Very rare." Near London.

\section{PYRAUSTA (SCIRANK).}

Tun Criason AND Golg (P.purpuralis, Curtss) "appears the end of May, in woody places. Wings five-sixtlis of an inch, purple-red at the base, with two rhomboidal golden-red spots at the base, about the middle a waved oblique band composed of irregular somewhat contiuent golden red spots, then towards the hinder margin a common regular order of golden red spots, which does not adjoin the nargin; second pair with a small line nearly to the middle, a very short band on the upper edge in the middle, and with an arehed one behind the middle, golcten white." Near London.

Tur Purpla and Gotd (P. muicealis, Curts) " appears the end of May and beginning of August, in woody places. Wings two-thirds of an inch to five-sixths, bright purple, or somewhat dusky, with two anterior spots, and a spotted band in the midtle golden red. Pcrhaps a merc varicty of the preceding." Near London.

The Scarce Perpee and Golo ( $P$. ostrinalis, Cumte). "Wings seven-twelfths of an incli; first pair ashy at the base, with an oblinue waved band in the middle of small irregular spots ; second pir lialf black, with a very minute spot near the bise, and a band rather behind the middle white, and behind this band a purple termimal one, which touches neither the inner margin nor the upper edige. Surrey," and ncar London.

TuE Ponrurry ( $P$. Pophyrintis, Stepmens) "appears the end of May, in woody places. Wings half an incli to three. fourths, purplish, with a large golden red or white spot among 
many very minute ones ; second pair blackish, with a band in the middle recldish gold or white. Found with the preceding, but unfrequent." Near London.

Tue Straw Barren ( $\boldsymbol{P}$, cespilalis, Curtis), "Wings seven. twelfths of an inch; first pair blackish, with two spots in the middle beneath the upper edge, one under the other, the last square-shaped, beneath these and the hinder margin a continu. ous white slightly waved band, which is rather thick at the upper edge; second pair black, with a band in the centre, and eommonly a streak on the hinder margin whitish; all the fringes brown. "Not frequent,"

The Deney Straw Bar ( $P$. sordidulis, Curtis), "Wings two. thirds of an inch, ashy-brown; second pair with a band belind the middle, and a very slender streak towards the hinder markiu whitisli, A variety of the preceding, but without the whitish spots and bands on the first pair. Not common." Near London.

\section{HYDROCAMPA (LATREXELE).}

Tue Lettered Chuna-Mark (II. literalis, Stwpmens), "Wings three-fourths of an inch; first pair brown, with a letter before the middle, a second angular and more conspicuous in the middle, and a posterior streak white : before the streak, and towards the upper edre a small white line; second pair ashy-white at the base, with a white curved band in the middle, another repanded towards the hinder margin, which almost reaches the inner margin; all the fringes alternately brown and white. Very rare." Near London.

Tuk Garden China-Mark (II. Sambucata, Stephens) "вppears the end of June, on shrubs and in gardens. Wings cleven. tweliths of an inch, all brown, very much spotted with white; before a common repanded streak of white spots; first pair with the tip ashy. Common." Near London, and in the county of Cork.

Tin Laran Citina-mark ( $\boldsymbol{I}$. Potamogatit, Strphens) "appears the end of July, about pools and ditches. Wings one incli one-twelfth to one-sixth, all variously clouded with white, with dusky uniting repanded bands ; fringes ash-coloured." Commou. Near London.

TuE Beautruul Cinna-marg (IT. Nympheata, Streinevs) "appears in July, in the neighbourhood of lakes. Wings five. sixths of an inch to one inch; all the wings and fringes very white, with various repanded unsolid somewhat dusky uniting bands. More uncommon than the former." Surrey and Rent.

Tur Siala Crina-dark (II. Lemmatu, Strpings) "appears the middle of June, about ditches. Wings of the male two-thirds of an inch, female two.thirds of an incli to one inch; first pair in the male generally pure white, with a black spot in place of a stigma, hinder margin ash-coloured; second pair snow white, clouded with black dots, with a short band in the middle of the 
linder margin, in which is a row of very bright silvery spots. The female differs from the male, is much larger, wings narrower and longer; first pair redish ash, with a very indistinct black spot; second pair more clouded, with more sumerous silvery spots. Very abundaut." Near London.

TuE Rinoen China-mark ( 1 . Strafiotulu, Stepuens) "appears the beginning of July, near lakes. Wings five-sixths of an inch to eleven-twelftis, redilish-ash, with two repanded brown streaks, having an interjacent white bind eyelet, with a brown iris; second pair with a very strong waved streak, and part of another in the middle," Near London.

\section{NYMPIUULA (SCHRANK).}

Tue Rusu Venekr ( $N$, hylutidalis, ScunANK) "appears in July. Wings one inch to one inch one-sixth, narrow, greyish brown, with two black trapeziform patches in the middle, one behind the other; second pair very ample brown, spotless, with white fringes. Coombe Wood, Chelsea, Wisbeach,"' and near London.

\section{DIAPIHANIA (STEPIENS).}

Tite Transranent China-hark ( $D$. lucernalis, StepHens). "Wings five-sixths of an inch, translucent pearly white, with the upper edge of the first pair and all the hinder margin broadly blackish; head and corselct black; aldomen very white or silvery, with the posterior barb for the most part black. Very rare." Near London.

\section{BOTYS (LATREILLE).}

The Garden Prbile ( $\boldsymbol{B}$. forficulis, LAtratle. "appears the end of May and end of July, in gardens. Wings one inch onetwelith to one-sixtlı; first pair with a streak drawn from the inner margin to the twin spot, which is in the place of the hinder stigmn, and about four streaks from the inner margin, confluent in the tip; second pair whitish, with a strong, rather incurved, brown streak behind the middle, and a second very slender and black on the inner margin. Abundant." Near London.

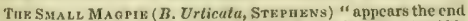
of June, on nettles and in gardens. Wings one inch one twelfti to one-sixth, long, white, with the upper edge at the base and the hinder margir ashy black, and a wary dusky band towards the hinder margin, beyond which is a strong white common btreak pectinated on the outer edge; second pair white at the base; body black; corselets, crown, margins of the scgments, and posterior beard yellow. Abundant." Near London.

MARGARITIA (STEPHENS).

THE VARieoated Pbanl (M. diversulis, Stepiens). Very rare. 
THE LoNG.WINOBD PEARL (M. Iongalis, SterneNs) " appears in Jume, on banks. Wings one inch one-forrth, longish, all asly. coloured, with a common wavy duskyish dilated streak, behind an indistinct and paler area in each wing." Near London.

Tue Motukn op Peare (ar, revticalis) Strpurns) " appears in Jaly, on nettles. Wings one inch one-third to one-half, all ple straw yellow, with three wavy dusks streaks. Abundant." Near London.

The Surpfur Pearl (at. palealis, Strpinens), "Wings one inch one-twelith to one-sixth, somewhat acute; first pairgreenish sulphur-yellow; sccond pair white, all the wing ribs dusky. Very rare in England."

TH: Center-gtrupe ( $M$, centrostrigalis, StepHeNs).

The Lasser PEATl. (M. limbalis, Stepitens) "appears in July, about inclosures. Wings one inch one-sixth; first pair yellow, indistinctly clouded with whitish, with two darker hincler streaks : second pair whitish, with two dusky streaks. Rather scarce." Near London.

Tue Srarce PeArL (M. hyalinalis, Steptras). "Wings straw. yellow; first pair with an incurved streak heforc, and a second larker, loroad and wavy behind the middle, common to all the wings, with the ordinary darker interjaceut stignata. Very rare. Keat, near Darenth Wood."

The Dingy Pexrl (M. glabralis, Stepuens). "Not very un. equal in size to the Lesser Pearl. Wings dull reddish-ash, with a common waved indented darker streak towards the himes margin, behind the large whitish spot in the first pair."

Tú Narrow-wingad Pearl ( $M$. angustalis, Srarnins). "Wings one inch one twelfth ; first pair narrow, but broader and shorter than in $M$. Longulis, and of a purer straw-colour, without asliy-krey, with two ordinary indintinct spots before a darker common repanded streak; second pair white, with the hinder margin straw-culoured. Very uncomanon. Kent, near Fevers. ham."

Tue Bondered Prarl (M, terminalis, Strphens). "Wings eleven to twelve lines, pale straw-coloured, indistinetly streaked, with a, common dusky border. Very uncommon. Kent, ncar Feversham."

The Decicate Prarl ( $\boldsymbol{M}$, pallidulis, Stephens). "Wings with a common streak bofore, and a second common behind the midifle, with a brown interjacent ringlet, with a dusky cross-line on the upper edge behinit the eccund streak, and a third shorter between the last and the hinder margin." "Rare.

THe Straw China-Matrk (M. Thapsalis, StbPuENs) "frequents woody places, but not in abundance. Wings tive-sixths of an inch, straw-coloured, with a streak before, and a second repanded 
behind the middle, with two brown interjacent dots; second pair whitish, with a central dot, before an indistloct repanded dunkyIsh streak." Near London,

The Suat, Straw China-mark (1T. ochrealis, Stepueve). "Very similar to the foregoing, but smaller. Wimgs three-fourths of au inch, usually without spots; first pair straw-coloured; seconel pair whitish, except in eertain positions the streaks are very indistinct or wanting. Kent, near leversham."

Tuв Lona-Legs ( $M$. longipedalis, Stépuens).

Thr Rusty China-Mank (M. Verbascalis, Steruess). "Wings five-sixths of an inch, all somewhat ncute, rusty-ash, with four streaks equally distributed, repander, common, and dusky, the linder one more indistinct. Very uneommon," Near Jontion.

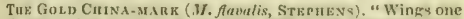
inch, somewhat acute, Fold-coloured, with three duaky stigmatr, the margins of which are alone conspicuous between two dark reanded streaks; sccond pair duskyish, with a hrown streak in the middle, and afterwards a second, composed of evanescent dusky spots. Unfrequent. Near London."

TuE Rusty Dor (H. ferrugulis, Stepuens) "appears in woody places, in August ( $?$ ). Wings three-fourths of an inch, rusty-red, with two dusky dots in the middle, the anterior stimma round and point-like, the hinder indistinct and kitncy-shaped; second Inir with a darker sput in the midlle. Very uncommon." Near Londion.

Tue Dustr Pearr. (M. puiveralis, Stephess). Near London.

ThF. Cinereous Prater. (M. cineralis, Strphevs) "appears in June, in woody places. Wings one inch, all dull ashy-red, with a brown cresccint before the common streak, which is repanded, darker, and exteriorly paler." Near London.

Tar Mahgined Pearr, (M. fimlrialis, Strpufans), Near L.ondon.

The Clay Pearl (M. uliginosnlis, Stepnens). Very rare.

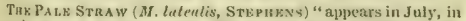
meadows and about hedges. Wings one inch, whitisl, indistinetly strenked, and having stirmata, whose margins are alone apparent and yellowish; the posterior angle of the second pair smoke-coloured. Abundant. Near Wisbeach."

THE DIA soxd SPOT ( $M$. tetrusountis, STEPUIENS) "appears in Augnst. Wings flossy, bomewhat dusk $y$, with a quadrangmar patch, and a bioad streak towards the hinder margin white; second pair clusky, with nu indistinct stroak darker, behimel the middle. Very uncommon. Near Coombe Wood."

The Cuated (M. cilialis, Stepukns). Very rare.

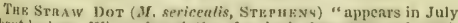
ahout hedges. Wings tive-sixths of an inch, deepstraw-colnured, with the kidney-shaped stigma of a burnt colour; the hinder 
margin more or less of a smoky tint, and a row of very minite white spots; second pair duskyish, but paler towards the bave," Near London.

Tub Pharl Straw (M, margaritalis, Steruens). Rare.

TuE CHeceueren Straw (M.elutnlis, STErurss) "appears ín

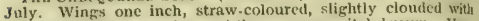
pitehy, with four streaks, and the nervures piteh-brown. Yiny scarce. Near London, but more frequent in Norfolk."

\section{SCOPULA (SCHRANR).}

THe Plum (S. Irunulis, OchsenheimkR). Rarc.

TuR Dusky BRinduen (S, nelulalis, STErikns) "appears the end of June, ou hedges. Wings one inch, all dusky; tirst pair with the stigmata and an arched strcak towards the hinder margin darker; second pair gencrally dusky, with a common streak of black dots on the hinder margin." Near London.

ThE WHITE BrINDLED (S, niupalis, STEPHKNa) "appears the end of June, about hedges. Wings one inch, clouded with white and whitish; second pair white, with a cresceat, spot, and border brown or dusky. Abundant." Near London.

THR PIED-CoAt (S. sticticalis, Stepriens). Supposed to be British on doubtrul authority.

Tix Staray Bundizd ( $L$. dentalis, Stephens), "Wing; eleventh-twelfths of an inch; first pair with the upper edre pale, having a dusky spot towarcls the tip, with a band just betore the middle, indistinct, pale, and on the outer edge deeply and slarply indented; between this and the hinder margin some palish clouds ; second pair dusky-ash. Very uncommon."

\section{NOLA (LEACH).}

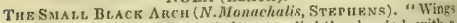
five-sixths of an inch; first pair hoary, sliphtly clouded, with s repanded and indented streak before, and a sccond more repauded and denticulated behind the middle; and beyond these an indis. tinct streak of black lines; the fringes ashy-grey, and after. wards marked with a row of black spots; the second pair with the fringes dusky, and without spots. Very rare." Near Lolldon.

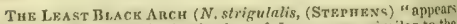
the end of May and the beginning of Junc, very similar to the foregoing, but smaller. Winps two-thirds of an inch; first pair whitish, posteriorly hoary, with two black dentieulated streaks; second jair white, rather ashy at the tip, with a small ordinary darker line or crescent in the centre, towards the upper edge, friuges whitish. Very unfrequent." Near London.

Tin Suort Czoakin, (N. cucullatella, Ster phens,) "apprars the beginniag of July near liedges. Wings two-thirds of au inch 
to three-fourths; furst pair being dusky at the hase, which colour terminates in a very strong black arched streak, then ashcoloured to the tip, but more frequently with $a$ wavy dusky very indistinct streak behind the middle, terminating in a blackish patch on the upper edge, and another contiguous very similar black streak, and behind these streaks an indistinct dusky bandlet, mather notched on the outer edge, near the hinder margin; second pair, and all the fringes dusky." Near London.

Thв Sноку Aвсн ( $N$, fuliginalis, StepheNs). Near London.

\section{TORTRICINA (RENIE).}

\section{TORTRICID K (STEPHENS).}

CHLOEPHORA (STEPTENB).

The GreEN Sicveu Lines ( $C$. Fighna, Steptekns) " appears in July in woods. Wings one inch three-fourths to fivc-sixths, green, with three very oblique and rather equally distributed streaks, the margins white, of the first pair with a reddish tint ; the male differs from the female in having the sccondary wings yellowish-green, with a thicker snow-white margin. Cruteryillar on oaks in May." Common.

The Scarce Shlyer LiNes (C.prasinana, Stkpiens) " appears the beginaing of June in woody places. Wings two inches, purest green, with two oblique streaks in the middle, the marpins and fringes whitish; the crown and corselet green, the antennx, palpi, and feet, red; the abdomen and under wings snowy-white. Cuterpillar occurs in September on oaks." Near Londor,

\section{TORTRIX (IIÜBNER).}

Tux Bondered GazkN (' $T$. plurann, llïBnR) "appears the beginning of Junc, about willows. Wings ten lincs one-half; first pair green, with the uprer edge white; second pair white or whitish, all the fringes for the most part whitish, but rather tinged with green," Near London.

The PeA Green (T. viridana, II worth) "appears in July", among oaks. Wings nine lines one-half; first pair green; second pair dusky; tringes generally white, but with a greenish tinge. Caterpiltar found about oaks. Very common."

THE Plain Ykh,ow ( $T$. flabant, IIAworth). "Wings nine lines one-half; first pair yellowish green; second pair dusky ; corselet and palpi grecuish yellow. Very rare in England." Near London.

THв Gumbder Rose (T, unitane, Hürnitr). Rare.

Tri Lrae Yellow ( $T$, Pillerant, Stepuens), Rare. 


\section{LOZOT ENIA (STEPHENS).}

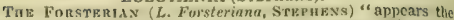
middle of June, about hedses and woody places. Wings one inch one-twelfth; first pair ashy-brown, with a brown spot in the middle of the tuper edge, a second between this and the hindter margin, and a third much larger in the middle of the inner edge, all these spots arranged in form of a triangle; sccond pair duskyish. Uncommon." Near London.

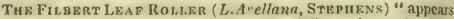
the berinning of July, but not commox. Wings eleven-twelfths of an inch; first pair obtuse, grey, with a yellowish tinge, with an oblique dusky band at the base, and a second behind the middle, which is often interrapted; and between this and the tip a dusky patch on the upper edge, triangularly disposed; sceond pair dusky, with yellowish fringe. Not common." Near London.

Tuв DArk Ontlouk Bar (L. Carpiniana, Stepunna) "appears about hedges. Wings eight to eleven-twelfths of an inch; first pait rctuse, brick-brown, with two darker bands, and a posterior patch on the upper edge. Common." Near London.

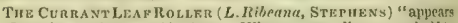
in June in gardens and hedges. Wings seven tines one-half to cleven lines, tawny, brick-red, with a basal and a ccntral band, and a posterior spot on the upper edge, darker and margined with brown." Too common.

THE Goosnarix LEap ROLhe ( $L$. Grossulurianu) Ste. PHENs). Near London.

Tue Chiray Jenp Rozida (L. Cerasana, Stwphens), "Wings nine to ten lines, retuse, brick-red, anteriorly slightly sprinkled with ashy, having two bands and a posterior pateh on the upper edge ashy-brick red, margined with dusky; second pair duskyish. Far from common." Near London.

Tue Smootu Onlque Bar ( $L$. lavigana, Stepness). Near London.

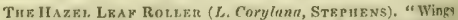
eleven lines one-half, retuse, brick red, very fincly checifuered with rust-red, with three unequi-distant rust-red streaks ; secund jair duskyish, yellowish at the tip, with numerous cross-brown lineg. Not common." Near London.

TuE Ros's Leap Roiller (L.Rosuna, Stephens) "appears the midlle of June, in gardens ahout rose.trees. Wings seven lines one-half toeight lines one-half, breal, retuse, somewhat hrick-red, with a streak at the base slightly arched, an oblique club shaped hand in the middle, and darker cross lines."

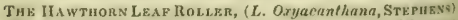
"Wings two thirds to three-fourtbs of an inch, duskyish, very sliglitly streaked with dusky; second pair dusky with a golden tip. Perhaps a mere varicty. Occurs about hodges." Near London. 
THz Vinurnian ( $\boldsymbol{L}$. Viburmuna, Strpitens). "Wings eight lines one-half; first yair dusky, sonewhat rotuse, shining, spotl'rs; second pair duskyish. Very rarc." Near Lotudon.

Tit: EYelet ( L. suboerllana, Stzpukns).

TIE Gafat Brows ( $\boldsymbol{L}$. fusrnna, STEPUKNs) "appears in woody places. Wings eleven-twelftis of an inch, all tusky, without spots; the frst pair retuse. Perhaps a mere large variety of the Rose. Caterpillar, suftused with dusky. Not abundaut." Near London.

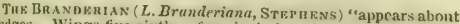
bedges. Wings five-sixths of an inch, broad, rotuse, dull-brick red; second pair dusky, oranpe-gold esloured at the tip. $\Lambda$ mere variety of the Rose Leaf Roller. Uncommon." Near London.

TH: Great Hook Tip (L. opnruna, StEpuevs) "appears the niddle of June, on herges. Wings one incl, somewhat tailed, tile-red, clouded with rust-red, and reticulated; second pair kolden-orange, but anteriorly dusky." Near London.

The Pyon sthan ( L. fulmana, Steprass). "Wingsfive-sixths of an inch ; first pair with an ustulated patch at the base of the imer margin, and an oblique central band; then a burnt-brown bandlet towards the hinder margin, which does not reach the inner margin on the upper edge; the tip itself longish and nstulated ; second pair of a rich orange-gold colour at the tip." Near London.

Thв Foпқвп Rri-rar (L.Xylostenat, Strpmens) "apjears in July, among oaks. Wimgs three-fourths of an incls to five-sixths, retuse, pale brick-red, with o patch at the base, an oblique slightly waved band in the centre, dividing into two brancies at the upper edge, and a small one towards the hinder margin, all brown, Frequent." Near Londion.

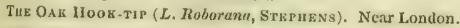

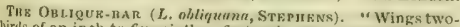
thirds of an inch to five-sixtlis; first pair retuse, ycllowish-ash, with a straightish band at the base, an oblique one in the midule, and a patch on the upper edpe towards the hinder margin, all indistinct and tawny, Uhe tip itself with an ustulated spot; second pair with the tip and thicker margin coppery-yellow." Near
London.

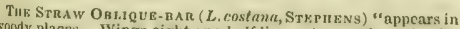
woody places. Wings cight one-half lines, straw-coloured, with a rery oblinue dusky-grey band in the middle, on the upper edge near the tip; a large conspicuous black match near the hinder margin from two to five black dots; sccond pair whitish. Not abundant." Near London. Tu: Douzhe Scorcueo (L. biustulana, Stzpuens), Ncat
Loadon.

Tue Monferian (L. Modemianh, Stefrens) "appears in summer among liedges in Kent, but uot common. Wings three 
fourths of an inch; first pair retuse, yellow, with an oblique inter. rupted central band, the upper edge and the tip inclining to ashy; second pair white, but gencrally half-ycllowish towards thie inner edge. Near London."

The Maplk (L. Acerana, Strphens) "frequents hedges; fist pair of wings oblong, blunt, dusky, with a somewhat arehed streak at the basc, an oblique club-shaped band in the middle, and a posterior pateh on the upper edge, indistinct, and of darket tint." Near London.

THE Afternoon (L. trifasciana, Strpmens). "Wings tro. thirds of an inch ; firt pair with an incurved streak towards the base, an oblique club-shaped baud in the midtle, and a patch on the upper cdike between the band and the tip brown, from the pateh proceeds a row of very close indistinct black spots; secend pair brown, all the fringes whitish. Not common." Near Lon. don.

Tuk Grotian (L.grotinna, Stephens). "Wings seven to cight lines; first pair obtuse, dull brick-red, scattered over with smatl cross reddish lines, with a thick forked band extending a littie beyond the middle, nearly to the tip of the upper edge; second pair brown." Near London.

THE SAHFR ON (L.eroreana, STErIIRNs). "Wings five lines one. haif to nine lines one-half; first pair narrow, blunt, brick-red, with a very obliqque band in the middle, and an anterior patch in the inner margin indistinct and darker." Nenr London.

TaF Ren Cross (S. cruciana, Streruns) "appears in woods, Wings six lines one-lialf to seven lines; first pair ash-coloured, dusky at the base, and having a large terminal band-like form, which is marked with a red cross; sccond pair dusky. Uncom. mon." Near London.

THe Grgy Red Cross (L. cinerana, Stephens). Accortine to Jaworth, a variety of $L$. cruciana. "The anterior wings ane ashy, and have a larke terminal spot, which is strongly arched, somewhat interrupted, indistinct, and generally clusky."

THE Honman (L.Holmiana, StFrnens) "appears the end of August, in chalky districts. Wings six lines one-halt to sered lines, rush-red, yellow, slightly ustulated, with an angular snow. white spot in tlie middle of the upper edge towards the tip, sprinkled with lead-colour; second pair dusky." Near Lonton.

Tuв Sспи в grey, with a white triangular spot on the nargin. Near London.

AMPHISA, (CURTI8).

THe Pectinated ( $A$. Gerningiunt, StepHens.)

Tue Walemrian (A. Walkeri, Curtis).

DITULA (STEPHENS).

TUE NARROW-WINGBD RED-BAR (D, ungustiorana, STEPUINS) 
"frequents shrublby places. Wings six to eight lines, narrow, oblung. blunt, smoky brick-red, with a patch at the base, and two oblique darker bands; second pair black." Near London.

THF ROUND-TIP, (D.rotundan/, STE PUENS\}. "Wings six lines, very bluntly rounded, smoke-coloured, with a patch at the base, and an oblique band in the middle brown; the first pair have also an oblique band towards the hinder margin, which is not brown, but clusky-burnt coloured; second pair deep black. Very uncommon," Near London.

The Bhigit Obrigue Dart (D. porphyriana, Stepuens). "Wings three-fourths of an inch; glaucous-nsh, glossy, witi three oblique dusky-brown bands, the upperedge variously spotted rith dusk $y$-brown; the second pair pitch-black. Uncommon." Near London.

Tak Clouded Iron (D. mebulana, StepHens) "appers in July, in woods. A mere variety of the preceding, but of dissimilar colour. Wings thrce-fourths of an inch, slightly iron-grey, with three indistinct oblique darker bands. Not very common. Kent," and near London.

THe RED Bцотси-RAC (D. syluana, Steraras). "Wings twothirds of an inch, brick-red, with indistinct streaks and bands, a common snow-white blotel in the centre; the second pair duskyred. Very unfrequent." Near London.

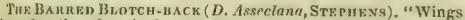
thire-fourths of an incl, dull grey, having three oblique darker streaks, fund as shortish one, with a common square snow-white patch in the middle of the inner margin; second pair dusky. Uncommon." Near London.

ThE ETHopran (D). Tethiopiana, Strpmens). "Wings three-fourths of an inch, black; first pair with a few spots on the upper edge towards the hinder markin, and a short streak ef patch on the posterior angle, the hinder margin itself and fringes pale red; second pair dusky. Very uncomnon." Near London.

The Short-Barred White (D. scriptana, Strinens). "Wings eipht lines one-loalf to nine lines, whitish, somewhat clouded, with a short black band in the middle of the upper edire, and the inmer edge ash-coloured, Uncommon." Near London.

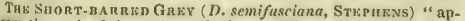
pears the end of August, on hedres. Wings elght lines onelalf, ash-coloured, and clouded with black; the first pair baving usually a short and somewhat dusky band at the base of the ujper edge, and a second one very similar and broader in the middle of the apper edge, which do not reach the dise; second pair dusky. Very uncommon," Kent.

ANTITIHESIA (STEPHRNS).

Tuk Marbled Lono-cloAK (A. corticana, Stepmens) "appears 
the ead of May :-September, in woody places. Wings five. sixths of an inch; first pair anteriorly varicet with white and black, and clouded, black in the middle, and posteriorly white; second pair dusky. Very unfrequent." Near London.

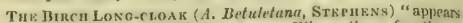
the inidalle of August, on bireh-trces. Wings three-fourthis to five-sixths of an inch, black, with deep clouds, and posteriorly white. Not abundant. Near Coombe Wood."

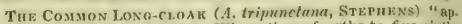
pears in summer, on liedges. Wings three-fourtlis to five sixths of an inch, black, with decp clouds, and indistinct brown patches; postcriorly white, slightly clouded with ashy. Very common." Near London.

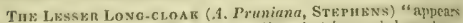
in Junc' and occurs with the precerling, but is much lessabun. dant. Wing seren lines one-half, black, indistinctly cluued with deep black, ashy, aral pitch-coloured, with a broad inter. rupted white band at the hinder marnin, this basd in the fire pair is interrupted in the middle by a black patch, and at the upper edre with three conspicuous black spots; seeond pair, dusky." Near London.

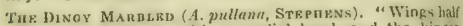
an inch, smoke-black, with o medial band, a d the hinact margin black; second pair pitch-black. Very scarec."

Tuh Borderey Long-cloak (A. marginanu, Strpazel, "Wings six lines two-thirds; first pair anterioriy obscure ath. coloured, towards the hinder markin with a pale yellow band, which has in the midile an asliy-grey patch, composed of from five to cight very close and minute black spots; the second pair whitrly, with a dusky margin. Very uneommon." Near I.ondon.

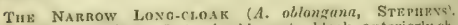
"Wings seven lines; first pair oblongate, black, anteriorly nb. scure ash.coloured. with a white band towards the posterior margin. Very uneommon." Near London.

Tue Gentias (A. Gentianeana, Steplins). "Wings two. thirds of an inch, somewhat dusky, spotter with piteh-colotir and black, posteriorly pale yellow dotted with black, with the hinder margin smoky; second pair jale dusky yellow. Uncom. mon." Near London.

The Wuite Backen (A. Salicella, Stephens) " ajpears tlie middte of August, and frequents willows, where the caterpillat is found. Wings five-sixtis of an inch, shut, half white on the hack, with the upper edge black and cloueled with decyer shades asud pale sky-bluc; second pair black, or nearly jet-black." Near London.

SPILONOTA (STEPHEN8).

Tuz Caudr Wute (S, nubiferana, Srephess) "appears thic 
middle of June, on hedges. Wings cight lines and a half; first jair bone white, somewhat clouded with asliy-grey, having a brond black fitlet reaching from the base to the middle; second pair dusky. Very unfrequent. Near London.

TH及 BLAck CroakвD (S. Cynosbalella, StzpizNs) "occurs in gardens. Wings nine lines and a half; first pair bone white, with the base and hinder margin black; sccond pair dusky. Near London."

THE Brown CloAkED (S. aquena, Stepinks) "found in gardens. Wings nine lines and a half; first pair ashy-white, with a band at the base, a posterior patch on the inner edge, and the tip dusky; second pair dusky." Not common. Near Londion.

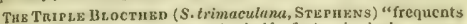
bedges. Wings seven lines and a half, first pair dusky, somewhat clouded with black, with two common whitish blotches, and a smaller interjacent one on the upper edge; second pair dusky." Near London.

Тн: Wнгтьроот ( $S$. fanella, StepheNs), "Wings nine lines to thirteen lines, dusky brown, posteriorly ash-coloured, with a large medial hook-shaped white band. Very uncommon. Near Wisbeach, Kent, and Norfolk."

THE TAWNy Blotch-BACk (S. rustienna, STEPHENS) "appears the end of August, on hedges. Wings two-thirds of an inch, tawny-asli, clouded, with a common rhomboidal white spot in the middle, the upper edge with minute black linelets, and three or four very minute black spots, disposed transversely in the middle of the hinder border; sccond pair dusky, with whitish fringes. Not abundant." Near London.

The Prevglan (S. Pfugianu, Strphlans). "Wings ten lines and 8 half, dusky, clouded, with two white half bands, which are partly contluent in the inner margin ; second pair dusky and shining. Very rare." Near London.

THE Stramian (S. Stromitna, Strritriss). "Wings cight lines, dusky brick-red, with two whitish half bands, sometimes tinged with yellow on the inner margin; sccond pair dusky and shining," Near London.

Tue Thromminiv (S. trigeminuna, Stephins). Near Lon. don.

THE Brown BцотсH-uACк (S. slicticuna, StEPHens) "appears in August, (?) on hedges. Wings seven lincs and a half to nine lines and a haif, dusky, clotded, with a white angular patch in the middle, and a second one terminal, ash-coloured on the inner margin, and with four or six white twin spots on the upper edge towards the hinder margin. Near London.

The Lesser Bцотси-васк (S. costipunctana, Stвpurss). "Wings half an inch, varied with dusky and ash-colour, with the upper edge pesteriorly white, with seven very close black spots, and a white patch in the middle of the inner margin. Very un. common. Norfolk.", 


\section{TuE Squane Blotch-back (S, tetragonane, Stepirens), Near London.}

The Black-enord Marale (S. nigricostuna, Stepuens). "Wings half an inch ; first pair obtuse, usually smoke black, with a large whitish-ash patch in the middle of the back; second pair black, with dusky fringes. Very rare." Near London.

Tuk Scorched Buent-wina(S.ustulanu, Strpnens). "Wings five lines and a half, smoky, with a band, and the hinder margin burnt black, with two tawny spots on the upper edge; secord pair and all the fringes decp black." Norfolk and near London.

Tue Cream Short Cloak (S. comitana, Stuphens), "Wings scven lines, banded with whitish and black, with from three to five close deep black minute lines towards the hinder margin. Common on bedges," Near London.

TUE BROWN-RORDERED (-, dorsana, STEPHENs) "appears the beginning of spring, (March i) on oaks. Wings seven lines; first pair dusky, slightly clouded with ash-colour, with a com. mon very indistinct ashy central crescent, in which is an obscure llusky strcak, the upper edge with numerous whitish spots, fringes ashy; second pair whitish, with a dusky border, and the finges very white. Very uncommon." Near London.

\section{PSEUDOTOMIA (STEPHENS).}

The Obscure Shyer Bar (P. obscurana, Stephens). Near London.

The Gray Sulver Bar ( $\boldsymbol{P}$ '. fraternanu, Strphens) "appears in April, (1) on hedges. Wings half an inch; first pair rather long and grey, with an indistinct silvery ashy band before, and a second oblique bchind the middle." Near London.

THE BrAck BondFR (P. atromargana, STRPheng) "appears the beginning of June, (?) on oaks. Wings five lines to six lines and a half, ash-coloured, clouded with dusky, with a common white patch, and indistinct somewhat silvery streaks, Not nbundant," Near London.

Tue Lignt Silver Stmpk ( $P$. Strobilella, Strenens) "appears the beginning of May. Wings four lines to five lines; first pair with an indistinct broad silvery streak towards the anterior margin, a second more conspicuous in the middle, and a third interrupted towards the hinder maryin; in the middle of the laet streak is a spot, or cross black line, then two or three very minute marginal black spots towards the posterior angle." Near Londion.

Tue Sirven Beotcu Bace (P. sequana, Stzphens) "appears the beginning of May, (i) on hedges. Wings four lincs and a half; first pair with very short white streaks posteriorly on the upper edge, and other angular cross silvery and yellow strcaks, three very minute black sjots also arranged crosswise on the 
binder margin towards the posterior angle, and a large common silvery patcl in the middle of the inner margin; second pair pitch black. Very rare." Near London.

Tuk Prtivian (P.Petiverella, Stuputens), "Wings five lines and $\mathrm{a}$ half to six lincs, dark tawny, with a common jatch in the niddle of a pale golden hue, and strongly crescent-shaped; the upper edge posteriorly streaked with lead-colour and golden : the fringes lead-coloured and shining. Not very common." Near London.

The Tramar ( $P$. concinnana. Ste

The Phain Silper Fringe ( $P$, simpliciant, Strpunes), "Wings seven lines, blunt, pale dusky, with bhortish streaks on the upper edge towards the posterior margin, three very minute cross black marginal spots towards the posterior angle; second pair dusky; the fringes of all of a bright silvery tint in certain positions." Near London.

The Jacguinian ( $P$. Jarquiniana, Strpkrns). "Wings seven lines, tawny, with a common patch in the centre, of a deep gol. dea tint and crescent form; the upper edge with tawny streaks towards the hinder margin. Not abundant." Near London.

Tur l'Lain Gol.D-pringkn (P. striganz, Stepuens\}. "Wings six lines to six lines and a half, somewhat rotuse, tawny, with rery short rust-red and silvery streaks on the upper edge to. wards the hinder margin, and the fringes of a brilliant goldcolour in certain positions." Near London.

The PURPLE Black (P. alropuryurana, StepnnNs), "Wings fire lines and a half; first pair of a briglit purplish black, with the fringes white, and of a splendid silvery tint in a certain light; second pair dusky, with the upper edge snow white, hut towards the tip the snow white colour appears sensibly tarnished." Very rare. Near London.

Tug Black Strmpk Engs ( $P$. nigricana, Stepunns) appears the end of August, on hedges. Wings six lines and a half, glossy and pitch black; first pair with numerous obligue white and black strcaks prettily disposed on the upper edge, and particularly behind the middle; in the middle of the hinder border are two or three contiguous deep black small lines in a row, all of which at intervals reflect a golden tint in certain direction. of light; second pair rather darker; all the fringes palc, shining, and usually silvery when vicwed in particuar positions.

Tre Pale Brown Strieg Enol ( $\boldsymbol{l}$. proximana, Stephens). "Wings half an inch, all pale dusky or ash-coloured and flossy; first pair, tn some lights, rather indistinctly tiuged with gold, with the upper edge very fincly streaked with wlite tawnyish; sccond rather darker. Very rare." Near London,

The Spotred Edge (P puncticostana, Stá Puens. Near Lon-
don.

Tug Taaunian (P.Trauniuna, Streriens). "Wings six lines M 2 
and a half, all deep black; first pair with a common spheroidal patch in the middle, and with six oblique yellow-white streaks on the upper edge towards the hinder margin. Very uncom. mon." Near London.

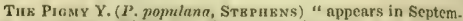
ber, on nettles. Wings four lines to six lines, all deeply black, with the upper edge posteriorly dotted with golden, deep-black, and very pure white; with a white Greek Lambda $(\lambda)$ in the midule of the inner edge. Far from common." Near Londc?.

The TrkanghK ( $\boldsymbol{P}$, trigonana, Stepirans). Near London.

Tiz Ledian ( $\boldsymbol{P}$. Lediana, Str fiens). "Wings four lines one. half to five lizes one-half, very obtuse, purplish black, and indistinctly clouded with dusky. Not common." Near London.

Thв Conpanion ( ${ }^{3}$, comitana, Strpizns). Near London,

Tuв Gundian ( $P$ Gundiana, Stwpmens), "Wings three. fourths of an inch, pitch-black, with streaks on the upper eige towards the hinder margin, and a common triple-striped patch in the middle, all silvery ; second pair deep black," Mr. Haworth doubts that this is a mere sexual difference of $\boldsymbol{P}$. compositella, trom which it differs only in the colour of the sccond pair of wings.

Thy Triple Stripe Buotch-васк ( $P$. composilella, St8. PrisNs) "appears the end of May (l) on oaks. Wings three lines and a half to four lines and a half, black, with three pretty dusky streaks on the upper edge towards the Jinder margin, and a silvery triple-striped patch in the middle; second pair snowy. white, posteriorly black. Not common." Near London.

THF Singla-STripe Blotch-BACK ( $P$. dorsana, Strphrxs). "Wings one-third of an inch; first pair pitch-black, with oblique black and silvery streaks on the upper edge towaris the hinder margin; a silvery spot on the margin itself; in the middle of the inner edge a somewhat oblique square oblong silvery patch in which is a prettyish black stripe; second pair white, posteri. orly dusky. Very uncommon." Near London.

The Double Oranee SPot, (P,aurana, Steruens) "frequents flowers. Wings five lines and a half, all black; first pair with a common obtuse crescent in the middle, and a large round patel in the middle of the hinder margin, golden orange. Uncom. mon." Near London.

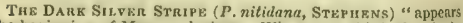
the beginning of May, on lsedges. Wings one-third of an inch, all black ; first pair with a central silvery-ashy bandlet, in wliclt is a very slender dusky stripe, and with very short black and silvery lines on the upper cdge towards the hinder margin; second pair deep black. Not common." Near London.

STEGANOPTYCHA (STEPHENS).

The Square-Barred Single Dot (S. tetraquetrana, Sts. 
PHENS) " appears in spring amongst furze. Wings seven-twelfths of an inch, Frey, with a rhomboldal band at the base, and postefor spot towards the inner margin, dusky; secund pair pale dusky, darker at the tip." Near Londion.

Tue Marnien Single Dot (S. mipunctanf, Stepinns) "found with the foregoing. Wings six lines to scven and a half lines, ashy-grey, clouded, with a rhomboidal band at the base, and $\mathrm{a}$ posterior dot towards the upper edge dusky; second pair dusky," NearLondon.

TuE ANGl b+barred Singlf Dot (S. triquetrana, Strpitex "has haunts similar to the preceding. Wings seven-twelfths of an inch, grey, with a triangular dusky-ashy band at the bose, and a rusky posterior clot towards the inner edge: second pair brown or dusky." Near London.

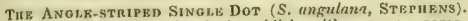
"Wings seven-tweliths of an inch, reddish, with numerous somewhat rectangular darker evanescent streaks behind the middle, a slightly waved, obscure, brovn-clouded band at the base, and a brown dot towards the posterior angle; second pair yale dusky. Not common." Near London.

THE Beberian (S, Beberana, Steptifns). "Wings seventwelfths of an inch, ash-coloured, with a large common spear. shaped black streak, reaching from the base to behind the mid. die. Not common." Near London.

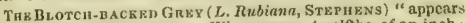
in August in woody places. Wings seven-twelnths of an inch; fint pair ash-coloured, minutely clouded with black, with the upper edge striped with black and white; the tip with a round ustulated spot; in the middle a common red somewhat ovalshaped patch, with a black borker; second pair dusky. Not common." Near London.

THE Pointed BAR (S. cuspiduna, STEPukNs). "Wings onc-half of an inch; first pair red in the middle, with a large and rather indistinct spear-like band at the base, which is black at the point, the hinder margin with a brond ash.black border." Supposed bj Haworth to be a mere varicty. Near London.

Tre Spotrup Rkd (S. stictana, Steprens). "Wings half an inch; first pair red, with small scattered black clouds or blotches; sceond pair dusky. Probably a mere varicty. Not common." Near London.

Thk Squark Bar. (S. rhombifasnizna, Stepmins), Closely allied to the foregoing, with which it is found. "Wings seven. twelfths of an inch, ash-coloured, clouded posteriorly with black, with a black trapcziform band at the base, and a reddish spot in the middle of the inner edige, as in $S$, Rubiana; sccond pair dasky." Near London.

Thв Motтlad Gaв (S, cinerana, Stepukns). "Very similar to the precedinf, but scarcely a varicty. Appears the end of August, in woody places. Wings seven-twelfths of an inch; first 
pair ashy, marbled with brown, towards the hinder margin an indistinctly blind and somewhat silver cyelet, having a brown iris; second pair dusky. Very rare." Near London.

\section{ANCHYLOPERA (STRPIENS).}

THe Variable ReD (A, retusunt, StrpueNs). "Wings six lines and a half, retuse, red, with a common ash-coloured spot in the middle, the upper edge obliquely streaked with white. Com. mon in woody places." Near London.

Tux R Rע Ilook-тup (A. subuncana, Stapuzns). "Wings six lines and a half, somewhat tailed, red, with a darker straight half. band at the base of the inner edge, and margined posteriorly with white. Frequents woody places." Near London.

THe BLent-Winero Brotch-Back (A. oblusana, SteramX). "Wings five lines and a half, obtuse, red, witl an irregular ashy band, bordered with white running wavingly from the back to the posterior angle ; the upjer edge of tise first pair numerousily striated with white and red, witis a red spot edged with white and red, with a red spot edged with white at the tip. In woods." Near London.

THк Иоок-тір Вцотен-ВАск ( $A$, uneulana, STEPHeNs), "Wings seven lines and a half, tailed, ash-coloured, with a large comnon burnt-red patch at the base, and another red posteriorly on the upper edge, slightly girdled with white. Woods." Near London.

Tuz Lundian (A, Lunduna, Sturuens). "Wings seven lines, tailed, pale, posteriorly tawny, with a rectangular golden streak towards the anal anglc, behind which are various, very short, oblique, somcwhat silvery streaks on the upper edge, with a very large common somewhat burnt-coloured ehestnut brown patch towards the middle of the base ; second pair dusky. In woods." Not common. Near London,

The Bnozen-aAR (A. fructifascianr, Stephens), "Wings yellowish, with two interrupted dusky-brown hands, and a row of brownish spots towards the linder margin. Uncommon." Near London.

THE Hook-TIPPED Streak ( $A$, siculana, StepHKNS). Wings seven lines and a half, having hook-shaped tails, ashy-red; the first pair with a white streak at the base, nearly to the tjp, and another in the middle, dusky, interrupted, to the tip, edked with numerous oblique dark lines; second pair pale dusky. Uncommon." Near London.

Tux Festoon Promy (A. diminutana, Stepurns), "Wings half an inch; first pair somewhat tailed, red, with a brosd waved ashy fillet through all the inner margin, which fillet is separnted from the red part by a distinct waved whitish streak; second pair asby-brown. Uncommon." Near London.

The Toncilet (A. finulana, Stephins). Very rare. Ncar london. 


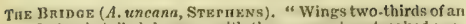
inch; first pair tailed, brown, with the upper edrse streaked posteriorly with white, and the tip longish, acute, and rather recurved; in the middle of the thinner margin, an arch, or large hemispherical patch, ash-coloured, and a second at the posterior angle almost contluent with the former; second pair pale dusky. Uncommon." Near London.

Th木 Double Areu (A. biarcuana, Stephens). Very rare.

\section{PHOXOPTERIS (TREITSCHKE).}

The Hookgd Manble ( 1 h, harpana, CurTs). "Wings twothirds of an inch, somewhat acutely tailed, white, slightly clouded with black, with the back half black and half ash-colourcd. Uncommon in hedges." Near London.

Tú Ben utryul Marale (Ph.nigromaculana, Cuntrs). "Wings half an inch; frst pair snow.white, ashy at the tips, with various minute black dots on the upper edge, a small black patch before, and another behind the middle; two large black patches on the innex margin, the first angular before the middle, and, as it were, two-fold, the other larger and almost at the posterior angle acutely conical; sccond pair decp brown. Very uncommon." Near London.

THe SNow Short-cloak (Ph, novana, Curts). Near London.

Tis Whiтb \$hort-cloAk (Ph, sociana, Curtis), "Wings: seven-twelfths of an inch, with white and black bands, the tip itself brown, with a round spot, the forehead and tips of the palpi snowy-white. Prequents sbrubberies. Unfrequent." Near London.

The Manelen Shout.choak (Ph. incurmana, Curtis) " appears in September, on heaths. Wings five lines one-half, varie. gated with white, black, and ashy, with a distinct black spot towards the hinder margin, before a small waved ashy bloteh."

Tus Paymulian (Ph. Paykulliana, Curtss) "appears the end of March. Wings half an inch, hoary-white, clouded with ash-eolour, black at the base, with a very slender black cross line or blotch on the hinder part of the wings towards the tip. Rare. Darenth Wood."

The Dounk, Croscent ( $\boldsymbol{P}$, sesquilununa, Cuntrs). "Wings half an inch; white, clouded, and with black lines, with at brown spot at the tip, common black crescent, and another brown; second pair dusky. Common on bcech," Near London.

Thi Retusk Marale ( $P h$. subocellana, Curts) "appears the beginning of July, about hedges. Wings five inches and a hajf; retuse, whitish, ashy at the basc, posteriorly with a lead-coloured patch, girdled with black, in an ashy band, the upper edge blark, obliquely lineated, tip with a brown spot edged with black; second pair dusky, with the fringes silky whitisin." Near London. 
Tun Овтusk Marble (Ph. Assecluna, Curtrs), "Wings Are lines and a half, obtuse, whitish, posteriorly brown, with a some. what silvery eye-like patch; all the markin ash-coloured, the tip with a round pitchy spot. Unfrequent." Near London.

TIIE MitternaciIAN (Ph. Nifterbacheriana) "appears in summer, on hedges. Wings six lines and a half to seven lines, brick-red, clouded, with whitish streaks on the upper edge, and a rectangular band. Very abundant." Near Loudon.

\section{SEMASIA (STEPIENS).}

Tirk Codurno ( $L$. Pomonella, Stephins) "appears the middle of Junc, common in gardens. Wings three-fourths of an inch; first pair browmish ash, with dark and very indistinct streaks, and a large somewhat blind eyclet towards the hinder margia, nearly at the anal angie, having a brighter iris, and being of a golden-red; second pair black, darkcr at the tip." Near London.

The Splendid Codina (S. Splendana, Sternens). Near London.

THe SMoky Marder (S. grossana, Strphens), "Wings cieht lines and a half, smoky-ash, with an oblique ashy-white band in the midale, before the black obscure blotch at the posterior angle; second pair with brown fringes. Very uncommon." Near London.

THE WoBerian (S. Waberiana, Steputsa) "appears in summex, about hedges and gardens. Wings six lines one-half to cirbt lines; first pair very beautiful, obliquely streaked with Golden, silvery, and tawny, with a somewhat eye-like patch at the posterior angle, indistinctly bordered with polden, and marked with lines instead of a pupil, with the frinfes gold. coloured in certain positions; second pair pitch-black. Common." Near London.

The RикеDian (S, Rheediella, Stepuens). "Wings half an inch; first pair from the base behind the middle semi-brown, posteriorly with four different gold-coloured streaks; second pair dusky, posteriorly yellowish. Far from common." Near London.

Thв Liout Striped Edoe (S.Innecolana, Steph BNs) "appears in spring. Wings one half to seven-twelfths of an inch, pale ash-coloured, with the upper edge streaked with white and yellow, with a somewhat eye-like silvery patch towards the hinder margin. Common." Near London.

The Yellow Stripen Edge (S. Hypericana, Stephins). "Wings laalf an inch, tawny-ycllow, with darker and paler streaks on the upper edgc, and a somewhat eye-like patch towards the posterior angle; second pair darker. Very wofrequent." Near London.

Tue Brautipul Canscent (S, perlepidana, Strpiens) "appears in spring, on hedges. Wings five lines one-half ; first pair varied with yehow and brown, the upper edge prettily streaked 
with brown and silvery, a somewhat silvery cresecnt on the back (of the wings), including between its horns a brown patch, fringes in certain lights very glossy and gold-coloured; second pair dusky." Very rare. Near London.

The Wonuwoon Everet ( $S$, pupillana, Stefiens). "Wings seven lines one-half; first pair whitish, ashy at the base, with an oblique band before, and a second behind the middle, and towards the posterior angle an indistinct eye-like patch, and from one to three spots on the tip of a somewhat olive colour, second pair dusky; all the fringes white."

THe Fulvova-Sfalen (S. fulmana, Stephens), "Wings five" sixths of an inch; first pair slightly tawny, with numerous oblique short, whitish, and tawny streaks on the upper edge, the tip acute, near the posterior angle an cye-like patch, having an interrujted silvery iris, with about three interrupted black lines in the place of pupils; second pair darker. Occurs in meadows. Very uncommon." Near London.

The Hoary Seajen (S. eana, Strfukns) "appenrs in summer, is very similar to the preceding, but differs in colours; wiags three-fourths of an inch, hoary, slightly clouded with tawny, the spots on the upper edge are more silvery, the eyelike patch towards the posterior angle more silvery and uninterrupted, with three less interrupted pupillary lines; second pair dusky, Found in meadows, and more abundant," Near London.

THe Scopolyan (S. Scopoliana, Steptiens), "Wings sevenmelfths to two-thirds of an inch, brownish-red, with a common ashy patch in the middle, and another more obscure at the posterior angle. Near London.

Tuk Rurous Arcu (S. rufanu, SrepheNs).

\section{CARPOCAPSA (TREITSCח Bв)。}

The A Rснеd ( $C$, areuna, Curts). "Wings seven-twelfths of an inch, yellow, with three arched bands, a biack three-cornered patel, and two small lines silvery. Uncommon." Near London.

\section{APHELIA (STBPHENS),}

Tuk Dusty Drab (A.egenana, STEPans). "Wings seven lines and a half ; first pair dull reddish, posteriorly, with very few mi. nute brown dots; second pair duskyish-white. Very unfrequent." Near London.

Tue Spotтеu Dra a (A. pauperana, StrouBNs). "Wings seven inches and a-half; first pair obliquely abrupt, dullish-red, with brown dots. Occurs amongst bulrushes." Near London.

The Lesser Dra (A. egpatena, Stephens). "Found with the preceding, to which it has great rescmblance, but its antenna are shorter and more slender; wings seven-twelfths of an 
inch; first pair reddish, obliquely abrupt, without spots, and the hinder margin blackish ; second peir dusky, with reddish-white frintses. The difference between this and the preceding is per. haps only sexual." Near London.

The Broan-strkaken Dra h ( $A$, plagara, Sterizns) "Wings seven lines and a-half ; first pair red, somewhat obliquely abrupt, with a very broad complete blackish patch, which nearly occu. pies a third part of the wing; second pair dusky, with paler streaks. Pulpi large, and very hairy." Near London.

Tut Pale Dвав (A. expullidana, Sтврines). "Wings half an inch, pale, lucent, with a tinge of yellow towards the upper edge of the first pair. l'ulyi more curved downwards. Very uncommon." Near London.

\section{CNEPHASKA (CURTIS).}

The Dotren DraB (C. quadripunctana, CurTis). "Wines, five sixths of an inch, rather lonp, dull yellowisls, glossy, with four brown remote sjots disposed in a square, and some brown dots posteriorly, the fringes silky white; second pair dull lead. colour, shining with larger white silken fringes. Norfolk."

The Lent (C. Cantiana, Curtis).

Thz Penzian (C. bellana, Curtss)。

'Tin Eigit-Dotтев (C. octomaculana, Curtis).

The LoNo-wingen (C. longana, Curris) "frequents meadows. Wings three fourths to fve-sixths of an inch; first pair rather long, roundish at the tip, ashy-white, with about thrce irregularly conthent cross brown patches before the middle, and other three towards the hinder margin, near the tip chequered with dusky; second pair whitish. Not common." Near London.

THE YLLzow DRAn (C. ictericana, STEPuENs), "Wings twothirds of an inch, duls yellowish, without spots. Occurs in meadows," Near London.

Tine Wayy Dra b (C. sinuana, Strpiexs). Near London.

TuE InDistinct Drab ( $C$, obsoletina, Stepiens), Near London.

The Laran Grey Era (C. assinuna, Curtis). "Wings fivesixths of an incli, whitish-ash, with brown bands, and a part of a band. Rare." Near London.

Tue Lesser Grav ElM ( $C$, interjectuna, Curtis). "Wints three-fourths of an inch; first pair whitish, with numerous black somewhat confluent dots, an oblique umangulated brown band at the base, and another complete, reaching from the middle of the upper ectge to nearly the postcrior angle; stcond pair pale brownish. More scarce than the preceding." Near London,

The Logian (C. Logiana, Curtrs). "Very common about elms. Wings one-half to two-thirds of an inch; first pair ashy, with three wavy brown black dotted bands." Near London. 
Tirz Straiontobarren Eral (C. rectifascinna, Curts). "Found with the former, but not so abundant. Wings one-half to seven-twcifths of an inch, white, clouded with ashy-grey, with three straight bands of an ashy-brick ret colour, and very much dotted with black," Near London.

THE Gold Banden (C. aurifasciuna, Stepnens), Near London.

Tuk Resinian (C. Resinella, Stkphens). Near London.

\section{ORTHOTENIA (STEPIENS).}

The Suoky Grey (Or. nubilana, Curtis). "Frequent in summer, on hedges. Wings seven-twelfths of an inch, obtuse, asliyblack, with a band and streaks of a deeper tint." Near London.

The Deн Prown (Or, nerfuscana, Hawortu?). Similar to the preceding in size, or larger and distinct; the palpilonger; antennae reddish and more slender; abdomen dusky. Wings seven-twelfths of an inch; first pair of a uniform black, and without spots ; second pair brownish. Very uncommon." Near London.

Tae Blotcrizn Drab (Or. quadrimaculana, StepheNs). "Wings nine lines and a half; first pair abrupt, reddish, or pale, with a tinge of red, with various dusky spots, disposed lengthways in the middle, the upper edge indistinctly dotted with rlusky ; second pair pale red. Kent. Not common." Near London.

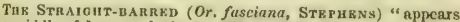
the middle of June on hedges. Wings seven lines and a half to nine lines and a half, red brown, somewhat clouded, with a straight darker band in the middie." Near London.

Thx Barred Netrle (Or. Urticana, Stepukns) "frequently accurs on nettles. Wings three-fourths of an inch; first pair ashy, with a straiglit brown or brownish-red band at the base, 8 second in the middle, straight, large, and broader at the inner margin, a third small, paler, and evanescent near the hinder margin, and not reaching to the upper edge, brown dots and lines posteriorly on the upper edge; second pair brown." Near London.

Tuk Silver Dotren (Or. micana, Stkpnens), "Wings seven lines and a-half, very similar to the foregoing, from which it stems to difier only, in having some very minute scattered clots of a silvery tint in certain positions, and having a streak of sillery dots behind the second band; second pair darker than in the last." Near London.

The Silver Striped (Or, qudulama, Stephens). "Wings seven-twelfths of an inch, very similar to the preceding, but smaller; first pair of redder hue, with a second band, broken on the outer edge towards the inner margin, a third, duskybrown band, not evanescent, all the bands in particular situations, more or Jess margined with silvery; sccond pair brown. Uncommon." Near London. 
Tile Marbied Doo's Tootu (Or, marmoruna, StePHens). "Wings seven lines and a-half; first pair ashy, with a broad unan. gulated band at the base, a second very short in the middle of the upper cdge, and a third rather short, and nearly opposite, but situated more posteriorly at the inner margin, dusky-brown, the tip brown, with an oblique white streak passing through the upper edge; sccond pair pale dusky. Very uncommon." Near London.

THE INDEviNith (Or, olsoletana, StepHens). Near London.

The Twin Streak (Or. bistrigana, Stephens). Near London.

Tue Sicver Marat,Fd (Or, Pinetuna, Stephens) "appears in July. Wings two-thirds of an inch, first pair varied with sil. very and yellow, having a broad stralght band at the hase, a larger one in the middle, and a third at the hinder vorder, all the bands marbled with silvery, yellow, and brown; sccond pair brown. Very uncommon." Norfolk.

The ReD BazRed Grey (Or. politann, Stephens). "Wings six lines and a-half; first pair shining, somewhat glaucous, with a broad oblique stripe of brown at the base, an oblique wary brown band in the middle, and a second, behind and broken, extending in an oblique direction from the upper edge to the posterior angle; second pair brownish. Very uncommon." Near London.

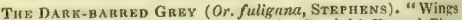
six lines one half. Very similar to the Straight Barred Elm, having the bands black without dots, and the second oblique and perfect, behind which are dusky clouds, and three conspicuous black dots, rather margined with whitish on the upper edge ; second pair brownish. Very uncommon." Near London.

Tuв Beaurirte Grey (Or. pulchellana, Strphens). Wings half an inch; first pair obtuse, hoary, with a large oblique unangulated brown band at the base, second strong, wasy, drawn from the middle of the upper edpe nearly to the posterior angle, in which, in the middle of the wing, is a tawny spot, the third band is composed of a semi-oval patch on the upper edge, and another opposite, pear-shaped, which almost reaches the inner margin, fringes brown, or black towards the tip of the wing; second pair lead-coloured, with snow-white fringes. Ex. ceedingly rare." Near London.

The Double-barren Oranoe (Or, bifilsciana, Strphens), Wings fve lines and a half; first pair yellowish, or yellow, mi. nutely striped with tawny, with a broad anterior, and rather oblique brown band, and a second pear-shaped on the hinder mergin, and dilating towards the upper edge; sceond pair brown, the upper cige ash-coloured at the base near the first band. Very rare," Near London.

TuL Gond Barred (Or. aurofasciuna, STKPhens) closely te. sembling the preceding. Wings fivo linesand a half, asby-browt, 
with two straight bnnds in the middle, and two posterior cross spots, obscurcly tinged with golden; second pair brownish. very rare." Near London.

THE MotTlin BRAN.(Or. purfurana, StepneNs), "Wings seven-twelfths of an inch, dull reddish-grey, clouded, wlth irregular dusky-brown patches. Very unfrequent." Kent.

The Faint Silvir Stripho (Or.subsequana, Stephens) "appears in April (?) Wings long, grey, lucent, with a brown spot at the tip, and three very slender, contiguous, black lines or stripes at the hinder margin and near the posterior angle; second pair whitish, silvery, with a broad spread of brown at the tip, fringes large; fringes of the first pair large, ashy, and very shining." Near London.

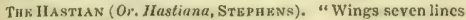
and a half ; first pair greyish-black, with asnow-white band in the midille, rather oblique internally, and on its outer edge bearing an obtuse prominent notch.

Tus Cock's IIsAD (- communana, Strpufns). "Occurs on trunks of trees. Wings seven lines to seven and a-half, variegated with black, brown, ashy, white or grecnish, with a patch in the middle of the inner margin resembling a cock's head. Very uncommon." Near London.

\section{POECILOCIIROMA (STEPIENS),}

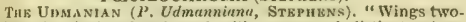
thirds of an inch, ash.colourcd, with numerous indistinct stripes, a small, common, somewhat oval, chestnut-brown pateh, bordered with white towards the hinder margin; sccond pair pale brownish." Not common. Near London.

Tie Sparmanian ( $P$. Spammaniana, Stepuens), "Wings nine lines and a-lialf to ten lines; first pair with the Greek capital Innbda $(\lambda)$ in the middie, broadly marked, slightly interrupted towards the upper edge, and of a rust-red brown, behind the latter a spot of the same colour towards the tip; second pair brown, Very uncommon. Near London.

Tuk Solandmian ( $\boldsymbol{P}$. Solandrina, StEputins) "appears in August, in woody places. Wings eight lines and a half to nine lines, pale, with a large common patch of a rust-red colour. Not common." Near London.

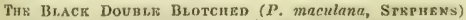
"appears the end of September, on shrubs. Wings five-sixths of an inch, decp brown, with black clouds, an obscure blackishbrown patch before the middte of the imncr margin, and a second near the posterior angle; second pair brown and shining. Very incommon." Near London.

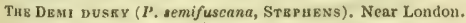
The Sarnino Prten (P. piceana, Stephens) "appears in Sep. 
temher, on heaths. Wings nine lines and a half, all bright; first pair pitch-black and without spots; second pair pale and dusky."
Near London.

The Graat Double Bar ( $P$. maurana, Stephens). "Wing's eleven lines one-twelfth; first pair pale brownish, or ash-coloured, with the upper edge indistinctly dotted with brown, a large brown band at the base, rather waved on its outer edge, and a second behind the middle, waved on both edges; second pair brown, all the fringes pale. Very rare." Near London.

\section{PTYCHOLOMA (STERHENS).}

Tá Lecrean ( $\boldsymbol{P}$. Lecheana, Strpiens) appears the end of June, in woody places. Wings seven-twelfths of an inch to three-fourths; first pair olire-brown, with the characters $3 \mathrm{~L}$ inscribed in silver colour." Near London.

EUCHROMLA, (STRPHENS).

The PUnPle (E. purpurana, STErHzNs). "Wings two-thirds of an inch; first pair bright purple, fringes of the same colour, with the upper edge pale and thickly sprinkled with purpisis dots; second pair with the fringes brown. Very uncommon." Near London.

TuE TAWNX-Dotreb (E. fulvipunctana, StzpHens). "Wings: two-thirds of an inch; first pair obtuse, of a doll reddiah-brown, and posteriorly marked with indistinct tawny-red duts; second pair brown, with whitish fringes. Perhaps a variety of the pre. ceding. Very rare." Norfolk.

\section{LOPHODERUS (STEPIINS).}

THE Yellow-BARRED IRON ( $L$. ministrunus, STfPIENS? occurs in woods. Wings threc-fourths of an inch; first pair rust-brown, with the upper cdge from the base to the tip, and 8 band towards the hinder margin, yellowish, the hinder margin and fringes rust-brown; second pair brown, with pale fringes.
Not common." Near London.

THe BaNued Iron (L. subfasciara, StreneNs).

\section{SARROTIIRIPUS (CvRTIS.)}

The Laros Marbled ( $S$. degewertanus, Curtis) "appears in July and in December, in woods. Wings one inch; first pair shining, whitish, clouded, with indistinct waved brown stripes, and elevated spots, a large tawny spot in the place of the anterior stigma, as in Noctuce." Sulposed by many, Mr. Ilaworth observes, to be a varicty of the LAnos HolLy (S. Ilicantes). Very uncommon. Near London.

Tug Lange Brown (S. dilutanus, Curtis). "Wings eleven. twclfths of an inch; first pair pafe ashy, with a red patch at the 
base of the upper edge, and another, triple as large, and longer in the midale of the thicker margin, at the bottom of the last an indistinct red spot, occupying the place of the anterior stigma as in Noctua, and in the forcgoing; between this spot and the hinder margin an indistinct waved streak of black dints, and on the margin itself another streak of very minute black dots. Perhaps a mere variety of the LARoE IHoLLY (S. Ilicanus). Norfolk. Near London.

Tú Apzelian (S. Afrelianus, Curtis) "appears the end of May, and perhaps a sceond time in autumn, or during the winter. Wings eleven-twelfths of an inch, brown, with a band at the base, and a thrce-cornered patch in the midale of the upper edge, with a fow elevated black spots. Found in groves. Perhaps a mere variety of the LARGB HoLLY (S. Nicanus). Very rare." Near London.

The Latianian (S, Zathamianus, Cerris). "Ilead and palpi above, snow-white. Wings ten lines and a-half; first pair pale brick-red, with the base and tip black with raised spots, a central bandlet with scales, and of a rust-brown hue, $\Lambda$ mere variety of the LARGW IOLLY, (S. Heanus)." Near London.

Thk Laron Holly (S. Ilicanus, Curtrs) "appears the beginning of August, in groves. Wings one inch; first pair broad, gshy brown, generally wavy, before the middle two approximating brown spots, then a solitary, central, deep black dot, towards the binder margin two or three approximating brown spots, a streak of brown dots on the margin itself; sccond pair ashcoloured," Not common. Near London.

TuF Brancied Hothy (S. ramosanus, Curtis). N'ear London.

The Stovanian (S. Stonanus, Cuntis). Very rare.

\section{PERONEA (CuRTIS).}

The RUsty Butron ( $P$. profanana, Curtis) " appears in Octo. ber, in woods. Wings nine lines and \&-half; first pair ashy-grey, with the upper edge somewhat hollow, the thicker border at the base, middle, and tip, ustulated, just before the middle an elevated and very singular handlet of ustulated dart-shaped spots, besides some minute dirty contiguous dots, and some of a larger size towards the hinder nargin; sccond pair brown." Very rare. Near London.

The Bnown Butron ( $P$, striana, Cuntis). "Wings five-sixths of an inch; first pair deep brown, with two small snowy-white dots on the hinder part of the upper edge, a large elevated spot in the middle, and minute cross dots near the posterior angle, brown, a broad ashy streak on the inner margin; second pair pale brownisl. Very unfrequent." Near London.

The Sub Brown Button ( $P$. substriant, StEphens). Near London.

Thk Plain Baown Butron (P, Urunueana, Steruens), Ncar
London. 
The Fillet Brown Button (P. viltana, Stepizens). Near London.

THz BAy-shoulnered Butron ( $\boldsymbol{P}$ spadiceana, Curtis) " ajpears in January, and perhaps in nitumn and during the winter, Wings tluree-fourths of an inch; first pair dusky-brown, scarlet red from the base behind the middle, with a large clevated black spot in the middle. Very rare." Coombe Wood.

The Conshmedr ( $\boldsymbol{P}$, consimilana, Strpinens). Near London.

The Desrontanian (P. Desfontainian, Strphens). "Winzs five-sixths of an inch; furst pair somewhat brown, the upper edge with a dusky border, very much rounded at the base, and rather hollow in the middle, a broad stripe or fillet, reaching from the base to the middle, of a golden-orange colour, and ter. minating in another very slender streak, which runs to the posterior angle; sccond pair whitish. Occurs in woods. Ficry unfrequent." Near London.

Tue Tawny Chest ( $P$, fulvocristant, Stephens).

THR WIITE Fulet ( $\boldsymbol{P}$. albovittana, STEPIENS).

Tu TAVNY Fillet ( $P$. fulwovittana, STEPHENS).

Tu Caystaling ( $\boldsymbol{P}$. crystalana, Curts). "Wings ; first pair yellow-brown with dark shades, a broad irregular white mark and a turt on the centre, with a short white streak at the tip; second pair brown; head and corselet white; abdomen brownish. Near London."

THe Sub-Fulet ( $P$. subvittana, Strfuens).

THE WHTE Butron ( $P$. cristant, Strpnens). "Wings eight lines and a hatf; frst pair brown, with an elevated spot in the middic, and a broad streak at the inner margin snow-white, near the hinder margin, especially towards the posterior angle, some elevated cross snow-white dots; second pair pale brownish; head, palpi, and corselet, snowy-white." Uncommon.

Tis White Dot ( $P$. albipunctana, Hawonti).

The Daq К Sтrkakвn Butron ( $I$ ', umbrana, Cuktis), "Wing, two-thiris of an inch, greyish rust-brown, with a fillet from the base to the tip, and an elevated black spot in the middle, burntbrown ; second pair brownish. lrequents woods. Very rare." Near London.

TuE Drvision Burton ( $\boldsymbol{P}$. divisana, Curtis). Near kondon.

Tie Streaked Butron ( $P$. strigana, Stepnans), Very rare.

Tuk Buff-Engen ( $P$. radiana, Curts), "Wings nine lines and a-half; first pair pale, with numerous confluent burnt-brown strcaks at the base, the thicker margin very much marked with pale; second pair pale brownish. Very rare." Near London.

Tuz Centre Fillet (P. centrovittana). Near London.

The Brancaid Streak ( $P$, ramostriana, Stapuens). 
Tue Combustan ( $P$. combustann, Curtis).

Tuk Grhy-strenk ( $P$.albistriunn, Cunts), "Wings five-sixths of an inch, trown, with a very faint tinge of purplish, the upper edge with dull borders, one ashy-grey streak at the inner margin, sone few dingy looking dots; second pair pale brownish. Very rare." Near London.

Tuв Autuanan ( $P$. autumnana, Cuntis).

TaE Subcrksten (P. suberistanu, StEPHENs).

Tuz Marblen Chestrut ( $P$. coromana, Stepuens)" appears in October. Wings five-sixths of an inch; first pair brown, with a contortuous or folded bloteh at the base, and another at the posterior angle snow-white; the upper edge of a dull colour, and rounded at the base, the second pair whitish. This is a very beautiful and remarkable species. Very rare." Near London.

THe Brninozrian ( $P$. Byringerann, Cuntrs). Near London.

Тни Indistinct Streakid ( $P$. obsoletenu, Sterugns). Near London.

Trk Ash-colouard ( $P$. favillaceana, StepuENs), "Wing five sixths of an inch; first pair variable, pale ash-grey, with dull coloured dots, and an irregular three cornered short band in the midtle of the upper cdge, of a dark colour; second pair alway's somewhat brownish, or pale dusky. Occurs in woods, but is not frequent." Near London.

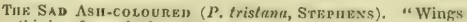
two-thirds of an fnch; first pair pale yellowish, with very indistinct dull-coloured dots, and a short irregular three cornered brown band in the middle of the upper edre. Perhaps a variety of the preceding. Very uncommon." Near London.

The Checounke Grey ( $P$. reticulana, Strpinss), "Wings nine lines one-half; first pair pale ash-coloured, checquered with brown; the upper edge with irregular indistinct, brownish dots; second pair pale brownish or whitish. Similar to the preeeding, but sufficiently distinct. Very rare." Near London.

The Rustr Sidws ( $P$, ruficostuma, Curtis.)

Tur Double Bay Streak ( $P$. bistriann, Curtis), "Wings: five-sixths of an inch; first pair rounded at the base, pale, and very slightly sprinkled with dots; the upper edge paler; ajretty scarlet-red streak, drawn obliquely from the base to the tip, and a second very similar, but slightly waved at the thinner margin, ruming fiocr and more strongly marked with red through the hinder margin to the tip; second pair pale and without spots. Very rare," Nearlondon.

Tue White Sides ( $P$. albicostana, Stepuens).

Tнв Simlanian ( $P$. similana, Stephens).

Tue Broad-Barró ( $P$. latifusciana, Curtrs) "appcats in 
September about hedges. Wings two-thirds of an inch; first pair ash-coloured, or hoary white, with an abrupt or three-cor. rered band at the base, and a very broad one rather behind the middle, of a darker brown; the latter extends to the hinder margin, the hinder margin is ashy-white; second pair pale brownish." Near London.

Tиe Lnad Cozourkd (P. plumbosanu, Curtis). "Wings two. thirds to three-fourths of an inch; first pair of a reddish lead colour, with the upper edge darker at the base, with elevated punctules; some minute, rather darker, scattered dots on the disc ; and in certain positions three dots, standing near to each other, and disposed in form of a triangle, in the middle of the thicker margin : second pair sometimes whitish, sometimes prle brownish. Not common." Near London.

TIE Boscan (P. Boscana, Curtis). "Wings two-thirds of an inch; first pair retuse, whitish, with some brownish-red scattered dots; a patch at the base of the upper edge, and another smaller and opposite on the inner margin; three other some. what confluent patches rather behind the middle of the thicker margin, and disposed in form of a triaugle; second pair pale brownish, with all the fringes brownish. "Very uncommon." Near London.

The Trioonian ( $\boldsymbol{P}$. Trigonana, Stapiens). Near I.ondon.

Tuz Schaldertan (P. Schalleriana, StrPtkNs) "appears the end of August in wonds. Wings seven-twelf hs to three-fourths of an inch, all whitish, with a blunt three cornered red patch in the middle of the upper edge of the first pair.

Tule Red Trianoli ( $P$. rufuna, Stephens) "appears the end of August on hedges. Wings seven-twelfths to two-thirds of an inch, rust-red, with a black triangular patch in the middle of the outer margin. Differs from the preceding in colour only. Very uncommon."

Thl Stde Spot Triangly ( $P$. costimaculanu, Stephens).

THE Logian ( $l$ '. Logiuna, Stgphens). Very rare, Near London.

Tue Wuite Sioutnnkn (P. asperana, StepunNs) "appears the beginning of August. Wings seven-twelfths to two-thirds of an incli; first pair anteriorly white, and posteriorly black. Common on hedges." Near London.

Tuz Coman Roven Wino ( $\boldsymbol{P}$ ', variegana, Strmerens) "appears the end of july. Wings seven-twelfths of an inch to two-thirds; first pair half ash-coloured, and posteriorly varied with black and red, with a dark cluster of elevated dark-shaped spots in the middle," Near London.

Tus Crested Buff ( $P$. borana, Strpuress) "appears the end of July, on hedges. Very simllar to the precedins, of which it is, perhaps, merely a variety. Wings seven-twelfths of a jine to two-thirds; first pair pale yellow, with a black high-crested 
patch before the middle of the inner margin, which extends almost to the base, a patch three times as large behind the middle of the upper edge, running nearly to the tip, and somewhat irregularly lobed; second pair pale brown. Very unfreguent." Near London.

PARAMESIA (STEPHBNS).

THE SUn-tripte Srot ( $P$. subtripunctulum, Stensns). Near Loudon.

Tнв Drax (P.gnomona, STrplleNs) "appears in September and October, in woody places. Wings seven-twelfths of an inch te two-thirds, somewhat retuse, iron-red, with three very indistinct spots, triangularly arranged in the middle of the upper edge. Common," Near London.

Thв Fon Strex ( $P$. lifidana, Stephens) " appears in September and October, but is more uncommon than the foregoing. Wings two-thirds of an inch; first pair somewhat retuse and nisty red, with an oblique brown band before the middle; then a perfect somewhat wavy band in the mildile, a brown streak to the posterior angle, and becoming inelegantly forked at the upper edge; second pair whitish." Near London.

THE Rustr Triple Srot ( $P$. tripunctuluna, StwpInNs) " appears in September. Wings seven-twelfths of an inch to two-thirds, somewhat retuse, rusty red, with three large brown spots, triangularly disposed in the middle of the thicker margin. Common in woods," Near Londion.

Tuk White Tripla Spot (P. cerusann, Stephisns) "appears the ead of July, about elms. Wings seven lines and a half, snow-white, with seattered ash-colourch dots, oftentimes clerated, and three black spots in triangular order on the upper edge, Very uncommon." Near London.

\section{LEPTOGRAMMA (CURTIS).}

THE BLACK SPRigöD GREsN ( $L$. literana, STEPHiNs) "appears the end of August, and the end of September. Wings threefurths of an inch; first pair scaly, very green, with various short straight streaks, and posteriorly black dots on the upper edige; some minute scattered black characters on the disc; $\mathrm{se}^{2}$ cond pair brownish. Occurs on oaks. Very uncommon." Near London.

The Green Tupt (L. squamana, Cuntis) "appears the end of Angust, on oaks. Wings aine lines and a half, scaly, greenishash, with the upper edge minutely dotted and sprinkled with brown; second pair brown. Very unfrequent." Near Lonton.

The Tr1-colourfo Green (E. tricolorana, Sternens) "appears the end of September, on oaks, very closely resembling the preceding. Wings nine lines and a haif; tirst pair ash-coloured, with a tinge of green, and black scattered dots; the upper edge anteriorly with cross waved black lines, and posteriorly with 
mumerous black spots; the disc also with black characters and conspicuous black clouds; a red stripe extends from the brse through the hinder margin to the middle of the upper edge, and seuds off a small branch towards the base; second pair brownish. Vcry rare." Near London.

Thi Srainkind ( $P$. irporana, Staphins). Near London.

Tue Mixed TAwny (P. fulvomistana, Stepuens), Near London.

Tue Gigy Rough-Wine (P. scabrana, Strphens). "Wings two thirds of an inch, ash-coloured, rather scabrous; the thicker margin of the first pair slightly hollowed, very much rounded, and iringed at the base, in the middle with three rough darker spots set in form of a triangle, and conspicuous in certain posi. tions ; second pair brownish. Frequents woods. Not common." Near London.

\section{GLYPHISIA (STEPHENB).}

The Chequered Notch-WiNo (G. emargana, Stepiens) " appears in autumn, in woods. Wings five-sixths of an inch; first pair from the base to the middle, and on the hinder nargin, brick-red, and chequered with brown; the upper edge from the middle to the tip much hollowed, or notched; a dusky .brown band extends from the border of the upper etge to the thinner margin, which is more or less tinged with red; second pair pale lrownish, and slightly lineated across, with brown towards the itpper edige. Uncommon." Near London.

THE IroN Notch-WiNo (G. excrvanu, StEpHkNs). "Wings nine lines and a half, deeply ferruginous; first pair with a band, as in the foregoing, but narrower, less ustulated, and not quite reaching the thinner margin; second pair as in the last, of which perhaps it is a varicty, but more scarce." Near London.

Tив Common Noteh-Wivo (G.effactana, Stвтнеns) " appears in autumn ; frequents woods, and differs from the preceding in colour only. Wings three-fourths of an inch to five-sixths, freyish-brown; the band is only conspicuous in particular positions, and is generally very indistinct." Near London.

Tuk SIAllow Noter -Wing (G. caudana, Sterukns). "Wings iwo-thiris of an inch to three-fourths, somewhat tailed, and nsliy-brey. Very similar to the last, from which it is distingruished at first view by the border of the first pair of wings, which is not so remarkable, or deep,-thence its English name; the thinner margin is red; second pair pale brown. Very scarce. Near London."

TuE Berv Notch-Wino (G, ochacea, Strpilins), Very rare, Near London.

DICTYOPTERYX (STRPHKNS).

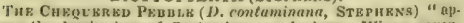
pears the beginning of September, on hedges. Wings seren- 
twelfths of an inch to two-thirds, acute, straw-yellow, very prettily chequered with red; the upper edpe at the base, and the band in the middle of the first pair, which is broad, wavy, and forked, are burnt-brown." Near London.

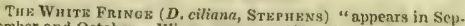
tember and October. Wings seven-twelfths of an inch to tireefourths, acute, rust-red, chequered with brown and red, with a central, short, oblique, darker band on the upper edge, which is not complete at the thinner margin. Found with the former." Near Lonclon.

Tuk Dare Cheoura (D. rhombana, Sterress) " appears in September and October. Wings seven-twelths of an inch to three-fourths; first pair acute, rust-red, somewhat reticulated, with a complete wavy, blackish, medial band. Found with the preceding. Common." Near London.

Tur Clounen Straw (D. plumbana, Steprisns) "frequent" woody places. Wings two-thirds of an inch; first pair straw. yellow in the middle, with two cloud-shaped patches or bands of a tull red colour, somewhat confluent, and slightiy forked at the thicker margin; second pair pale lead-coloured. Not common." Near London.

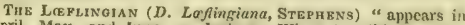
April, May, and June, on hedres. Wings two-thirds of an inch; first pair straw-yellow, with very numerous reddish and minute clnuds on the disc, and the double character $\mathrm{X}$, of $\mathrm{a}$ simi. lar colour, impressed on the midule of the upper eclge." Near London.

ThE Fongralian (D. A. Forstialeana, Sterums) "appears the end of August, on hedges. Wings half an inch, brick-red, very prettily chequered with red, with a short, broad, oblique bani on the thinner cdge. Variable." Near London.

TERAS (TREITSCIKR).

The TaIted Bupy (T. caudana, Curtis); Near London,

\section{CIIEIMATOPIILA (STEPHENS).}

Tuk Dotted Cuestaut (C. easluneant, Stepinas) "appears during winter. Wings seven lines one-half to eiglit lines, chest. nut-brown, shining, with very minute dots or atoms; second pair dusky. Uncommon." Near London.

\section{ARGYROTOZA (STEFIENS).}

Tur Bergmannian (A. Bergmanniana, Stephens) "appears in August, in gardens. Wings half an inch; first pair $y c l$ low, more or less suffused and chequered with red, with four somewhat arched, and equally distributed streaks of silver dots, the first at the base, and the last at the hinder margin; sccond pair brown, with all the fringes yellow. Common." Nenr Loudion, 
Tuk Conwayian (A. Contunyana, Staphens) "appears the midale of June, in groves. Wings fve-twelfths of an inch to one-haif; first pair tawny, slightly clouded with brown, with a yellow spot in the middle of the upper edge, and another opposite on the thinner margin: with about five irregular streaks composed of silver spots; second pair brown or black. Not common."

The Pale Orange (4. subaurantiana, Steribns), Near london.

The IOFfmansegotan (A. Hofmansegginna, StzpHExs). "Wings five-twelfths of an inch; first pair tawny brown, with five interrupted silver dot-streaks, the sccond terminating bey ond the middle in a common yellow line in the thinner margin; scond pair black. Perhaps a mere variety of $A$. Conwayana, but without the yellow spots on the margin. Not common." Near London.

TIв ORANer AND Black (A.permixtana, Strpiens). "Wings one-third of an inch to five-twelfths; first pair golden-red, with a cross paler patch before the middle of the upper edge, which terminates in a common black threc-cornered patch on the thinner margin ; belind the middle a broad greyish-black band; second pair snow-white, posteriorly black. Not common." Near London.

TuE DAldorfian (A. Daldorfiana, Steprens) "appears in spring. Wings one-third of an inch, blackish-brown, glossy, posteriorly red, etreaked with golden; second pair black, with red fringes, Not common." Near London.

\section{ARGYROLEPIA (STRPRENS).}

Tur Silven Spotted (A. Lathoniana, Stwphens). "Tirst pair of wisgs yellow, spotted with silvery. Very rare."

The Bentegyan (A. Benlleyana, Haworti). "Wings brown rust-red, with numerous strcaks and dots of a silvery yellow colour. "Very rare."

Tub Oranoz Spotrab (A. Turionana, StвpnENS) "frequents kardens. Wings one-half of an inch to five-sixths; first pair rather long, blunt, and all the fringes whitish, with numerous, somewhat obscure, patches and dots, of a tawny-red, orangegold, or golden lustre, and contluent on the hinder part of the wings ; secoud pair black. Scarce." Kensington.

Tú Geamed (A. gemmana, Stephens). Near London.

The Silvary Broad Bar (A. aneana, Strpiens), "Wings half an inch; first pair of a pure yellow, with a strong, straightish, black band in the middle, and a similar one on the hiniler margin, both dotted with silvery; second pair black. Very rare." "Near London.

Tuz Tesgellated (A, tesserana, Steprens). "Wings half an inch to seven-twelfths, tawny, chequered with five very white or gold-coloured patches; second pair brown. Very uncommon." Near London. 
The Dechanium ( $A$. decimana, Stepabns). Near London.

THE BAUmanian (A. Baumanniuna, Haworti) "appears in May, (?) in groves. Wings five lines one-half to ten lines onehali, first pair of an ashy. colour, with two angular, approximating, interrupted or uniting bands, edged with silvery ; second pair brown. Variable. Uncommon." Near London.

\section{EUPGCILIA (STEPHENS).}

THE SNALL BLACK-SPOTTED (E. maculosant, StrPHens). "Wings five lines one-half to six lines; first pair white, ashy at the base, with a rather wavy-brown, black-dotted band before the middle, which scarcely reaches the upper edge, behind this and as far as the tip, irregular brown patches; second pair brown, with white fringes. Not common," Near London.

Tire Barred Marele (É, angustana, Stkrmkns). "Head and corselet pale-yellow. Wings five lines one-half to six lines; first pair pale yellow, with a straight brown band in the middle, and the hinder margin of the same colour, but very faintly towards the thinner margin; second pair whitish, with a dusky margin, and white fringes." "Near London.

The Dinoy Dwarp ( $E$. pygmeana, Stermens). "Wings one. third of an inch; first pair variously clouded with black, and sprinkled with ash-colour, but particularly in the middle, and at the tip of the thicker margin; second pair black, with brown fringes. Very uncommon." Near London.

TKE BARRED DWARP (E. nana, StepHeNs) "appears in July, and frequents heathy districts. Wings five lines one-half; first pair pale ycllow, ashy-grey at the base and upper edge as far as the middle, with a broad brown baud in the midale, in which are one or two yellowish dots; the thinner margin and posterior streak or bandlet brown; behind this the wings and frimges are altogether pale yellow, and without spots; second pair brownish, with whitish fringes. Very uncommon," Near London.

The Yellow Dwarf (E. luteolana, Stephens). Near London.

The Doubtrul Difanf ( $\boldsymbol{E}$. dubitana, Stepinss). Near London.

The Brindlew Marale ( $E$. Sodaliana, Strprens). "Wings fve lines one-half; first pair varied with snow-white and ashgrey, with black patches and spots on the upper edge, a black patch interrapted in the middle rather behind the centre, and another somewhat incurved, waved, and brows, near the hinder margin; sccond pair brownish. Very rare." Near London.

Tue Hoary Dounle Crescint ( "frequents ash-trees. Wings half an inch, white, clouded with ash-grey, with two common crescents on the back, one deep black and the other ash-coloured; sccond pair whitish, Not variable. Very uncommon." Near London. 
The Ligit Marblap (E. albana, Steptens). "Wings six lines one-half; first pair snowy-white, slightly clouded with ashgrey, ashy -brown at the tip, with a common ashy patch before the middle, composed of three approximating black distinct streaks, but interrupted with white, and another common, hinder, acutely conic, black patch; second pair whitish, darker at the tip. Uncommon," Near London.

\section{COCHYLIS (TREITSCIKE).}

Tule Rosy (C. rosernu, Curtis) "frequents marshes, Wings half an inch ; first pair rose-coloured, with an oblique perfect loand in the middle, touching with its outer edge a pale indistinct patcls in the thinner margin, the fringes rose-colource, with burnt-brown tips, the upper elge posterioriy, with three inclis. tinct darker spots; second pair dusky, with the fringes paler. Not abundant." Near London.

Trk Dixoy Rosy (C. subroseuna, Curts.) "Wings fire. twelfths to half an inch; fir:t pair rosy-grey, with a short brown oblique band in the middle of the thinner margin: poste. riorly ashy.brown. Not common." Near I.ondon.

THE lRen Frinof (C. ruficiliana, Curtis) "appears the end of May. Very similar to the preceding. Wings half an inch; first pair lead.coloured, with a very oblique short band in the middle of the thinner margin, and red fringes: also a second brown band in the hinder margin." Near London.

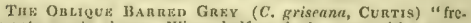
guents woorly places. Wings half an inch, exey, with a some. what waved band in the middle, and part of another on the anterior part of the wing, brown; second pair brown. Uncom. mon," Near London.

Tue Makginian (C. marginuna, Strpriens)? Near London,

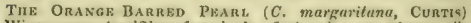
"Wings seven-twelfths of an inch; first pair very glossy, sil. very-pearl, with the base, a spot at the base of the upper edge, then two oblique interrupted bands, of an orange-fold colour ; a third band, more complete, at the hinder margin, situated behind an orange-gold spot on the upper edge; sccond pair decp-brown. Very rare."

Tue SMeathannian (C. Smeathmanniana, Curgis) "appears the end of July. Wings one-half to two-thirds of an inch; first pair straw-colourcd grey, with a brown patch at the base of the upper edge; then an oblique tawny-brown band in the middle, somewhat angular, and broken about if s centre; betwen this and the hinder margin another short, broken, band, but more con. spicuns at the upper edge; sccond pair black. Not common." Battersea.

\section{PHTHEOCIIROA (STRPIRNS),}

Tul Rovon Wino ( $P$. ragosuna, Stuphexs) "appears the 
Jeginning of June on hedges, Wings cight lines onc-half; first pair whitish ash, rough, with white patches, lines, and streaks on the upper edige; second pair asli-grey. Not common." Near London,

\section{LOZOPERA (STEPIENB),}

\section{TiE Stephessian (L. ulternana, StipubNs).}

Tae Shont BARren Straw (L. struminea, Strpukns) "ap. pears the end of June, in meadlows. Wings two-thirds of an inch; first pair pale straw yellow, with a short olfigue tawny bundlet rather before the middle of the inner margin, and reaching towards the upper edge; second pair whitisl, with very large silky-white friages, Very uncommon." Near London.

Tre Farrician (L. Fubriciana, Strpmens). "Wings seven. twelfths of an inch, slender; first pair pale straw-yellow, with a band, as in the last, opposite to the patch on the ujper cdige; and behind this band, another very similar band also, opposite the pateh on the upper edge; the bands are oblique, interrupted, and brown ; second pair pale brownish. Not common." Near London.

Tuk Francri.onian (L. Francillana, StepuENs), " wings half an inch, of a deep straw-colour, with two oblique complete brown bands. Very uncommon." Near London.

\section{XANTHOSETLA (STEPRENS).}

T'UE Z Z GIAN (X. Zagana, STEPUKNS) "appears the beginning of August on grasses. Wings three-fourths of an inch; first pair yellow, with the upper edge at the base, and a spot in the middle near the thinner margin, rust-red; the hinder margin also rustbrown, with a rather large, hemispherical, yellow patch." Near London.

The Clouded Iron ( $\boldsymbol{X}$. ferrugana, Staphans). "Wings twothirds of an inch; first pair iron-brown, posteriorly brown, with an iron red patch. Very similar to the last, from which it only differs in the colours of the first pair of wings. Norfolk," and near London.

TuN Hook-MARKED Straw (X. hamana, StePXeNs) " appears the beginning of Aupust on grasses. Ifead, antennse, palpi, and vent-tuft, yellow; abdomen brown. Wings threc-fourthis of an inch; first pair yellow, with a minute and very indistinet dot in the middle towards the thinner margin; and an oblique hookshaped bloteli towards the hinder margin iron-coloured; the bloteh runs from the posterior angle towards the middle of the wing, where it becomes twavy on its outer edge; second pair dusky, with whitish fringes." Near London.

The Crossmo Srraw (X. diversuna, Strpiens) "appears the heginning of August on grasses. Very similar to the foregoing. Wings three-fuurths of an inch; first pair ycllow, with the upper cdpe at the base, a patch in the middle, and a common posterior arch iron-coloured; a streak arched on its outer cdge often insues from the patch in the centre of the upper edge to the 
thinner margin. In the hinder part near the posterior angle is a blotch, which, when the wings are shut, has the appcarance of an iron.coloured cross, and extends to the arch on the upper edge." Near London.

TUK Phatn Dran ( $\boldsymbol{X}$, inopiana, Stephens). "Wings three. fourths of an inch; first pair shining, reddish, or pale yellow, rounded at the tip, and without spots; second pair dusky red, and shining, as if smeared over with oil. Very rare." Near London.

\section{PHiBALOCERA (StrPaENS).}

THR LONG-HORNED ( $P$. Quercunu, STRPHENs) " appears the beginning of August in woods and gardens. Wings two-thirds of an inch; first pair reddish yellow, with two patches on the upper edge, and the fringes primrose yeliow; second pair and fringes white, but the latter are yellowish at the posterior angle. Common." Near London.

HYPERCALLIA (STEPHENS).

Tue Curistikrnian (H. Christiernana, Sterikns) "applears in June and July about hedges in chalky districts. Wings two. thirds of an inch; first pair and fringes deep primrose yellow, very prettily chequered with blood-red; second pair dusky with yellowish fringes. A beautiful species. Very uncommon." Near London.

ORTHOTELIA (STEPHENB).

The Vernous ( $O$. venosa, Stкphens). Near London.

Tuz Silky (O. sericea, Curtis).

\section{XPONOHEUTIDIE (STEPMENS).}

DEPRESSARIA (HAWORTH).

Tив Cow Parsnap (D. Herucleana, Stepuens). "Wings one inch, depressed and grey; first pair with approximating black lines on the disc. Caterpillar green, dotted with black, with threc indistinct lines on the back; it is first found in the umbels of umbelliferous plants, penetrating through the stems of the leaves of flowers, that are contortuous and bend town. wards," Near London.

THg Large-strRaked (D. Umbellann, Stepuens). "Wings eleven-twelfths of an incl, smooth, with streaks, and of a grey colour, with approximating black patches on the margin of the disc. Caterpillar green, with the head, neck, and two rows of dots on the segments, black. Norfolk." Near London.

Tue Brown-vinen (D, putridella, Stephens). "Wings ctpht lines one-half; first pair pale, with a very short black streak near the base of the thinner margin; in the middle, but 
near the upper edge, four spots, disposed in form of a square, of which the two anterior are minute and black, the third rather large, roundish and brown, the fourth minute, and somewhat eje-like, with a black and white pupil; the hinder margin with \& row of black spots; second pair whitish, with the fringes large, straw-yellow and silky. Very uncommon," Near London.

Tuz Wayscot Flat Body (D. Yenosa, IIAwortu), "Wings firc-sixths of an inch; first pair somewhat abrupt, blunt, red, with all the wing ribs slightly whitish, and a large brownish patch towards the hinder margin: second pair white. Far from common." Near London.

The Brindeen Flat Bony (D. apicella, Strpuens). "Wings cight inches onc-half; frrst pair ashy-grey, clouded with dusky, with a minute snow-white dot cxactly in the middle, having a dusky cincture, also with scattered brown lines; second pair paic." Near London?

THE CoAnse WAINscot (D. nervosa, IIAworru). "Wiogs three-fourths of an inch; first pair red, with the wing ribs posteriorly, the hinder margin, and the fringes much darker; nearly in the middle, and in the place of the anterior stigma, are two very minute, almost connected, white dots, bordered with red; sccond pair whitish, with a very faint tioge of reddish. Un. common. Near London."

TIR BRown Brindefe ( $D$, badiella, STEPIrkNs). "Wings two-thirds of an inch, brown, with numerous, scattered, darker lines. Not common." Norfolk.

TBe LesSER Fuat BODY ( $D$, characterosa, HA worth). "Wings two-thirds of an inch, grey, somewhat clouded, witi the upper edge rosy, marked with a (?) and interrupted in the middle with black. Unfrequent." Near London.

Tue PURpie Flat Body (D, liturelia, Strphiss). "Wings two-thirus of an inch; first pair of a dull or ashy purple, with a pele, straight, and slender band in the middle near the base; socond pair pale brown. Very rare." Near London.

\section{Bunnt's Flat Bodv (D. Bluntii, Curtis).}

Tвк Common Flat Bont (D. applana, IAwontu) "appcars the end of August, and frequents gardens and hedges. Wings three-fourths to five-sixths of an Inch, depressed and brown, with three white spots in the centre. Variable." Near London.

Tue Curve Dotrin (D. curvipunclosa, Stephens) "appears the beginning of March. Very similar to the preceding, but smaller. Wings seven-twelfths to two-thirds of an inch, grey, somewhat sprinkled with brown dots, with a minute black line, curred in the middie, and interrupted. In good specimens the head, corselet, and base of the first pair of wings are whitish or pale. Irequents hedges. Far from common." Near London.

Tue Rufous Banden (D, albipanctella, Strphens). "Wings three-fourths of an inch, red, very slightly clouded, with a con. 
spicuous large white spot in the midtle, beneati a large, roundish, conspicuous black one. Uncommon." Near London.

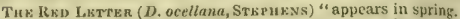
Wings mine lines one-half; first pair ashy-coloured, with a een. Iral, oblong, blood-red bloteh, in the hinder part of which is a small white dot, the hinder margin dotted with black; second pair whitish. Very rare. Near Chelsea."

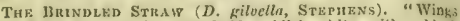
nine lines to nine lines one-half, reddish-white, with a black patch, and spots in the middle of the same colour. Variable," Near London.

The Divey Straw (D, costana, Haworth. "Wings two. thirdy of an inch, red, with a large, oblong, brown yatch in the centre, reaching to the upper edge, with the fringes rosy. En. frequent. Near London."3

Tue Sprinkled Straw (D. irrorella, Steprens). Near Londion,

THE THstaz Strav (D. carduelle, Steptens).

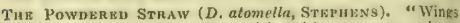
cight lines one-half; first pair reddish, with numerous minute black abd rosy scattered dots; second pair white. Uncommon. Near London."

Tum Sparmannian Srraw (D. Sparmantiana, Strinens) "frequents meadows; body pale. Wings nine lines one-half, flat and all pale; first pair rather darker, with two small distinct unapproximating black fots on the dise; the hinder margin dotted with black; second pair without spots." Near London.

Sia Spothess Straw (D. immaculana, Stephens).

Yeatws's Straw (D. Yatesana, Steprens). "Wings eight lines one-half, first pair grcy, with a black central patch, and two black dots, obliquely placed, and approximating; four or fire black spots on the Jinder margin; body ash-grey; antenne black. Uncommon. Near London."

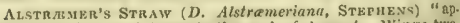
pears in spring, and towards the end of August. Wings twothirds of an inch, whitish; first pair in the middle, towards the side margin, with a brown patch iron brown on the inner edge; at the hinder margin witl black furrow-like streaks, and the margin itself dotted with black; second pair ashy-white; beneath dull whitish. Common about hedges. Near London."

The Lassir Purpen (1), purptrea, Curtis) "appents in spring. Wings half an fnch, first pair purplish-red, with the upper edse brownish, thickly sprinkled with rose-red, and having a large brown patch in the midale, indistinctly marhled on both sides with pale; second pair brown. Not common. Near London."

ANACAMPSIS (CURTIS).

THE JUNiper (A. Juniperella, Sternens) "frequents poplars. 
Wings seren-twelfths of an inch; tirst pair asb-grey, with four black spots, disposed without order, posteriorly with a white waved streak; the hinder margin with black dots; second pair whitish. Common." Near London.

TuE Porlar (A. Populella, Sthphins). "Found with the vreceding, to which it has greatresemblance, but is smalter. The antennie short. Wings seven-twelfths of an inch to two-thirds, firt pair ashy, clouded with dusky and black; second pair leadcoloured; the hinder shanks of the legs yellowish. More scarce than the preceding." Near Jondon.

THE DArk Brown (A, musticella, Strpugns). "Wings seven lioes one-half to eibht lines, narrow, deep brown, without spots, and roundish at the tip. Frequents gardens. More scarce than the forcgoing." Near London.

Curtis's Long IIon ( $A$. longieornis, Curts).

LISTER's (A. Listerella, STriskns), "Wings seven-twelfths of an inch, first pair pale-brown, with three or four rather darker evanescent scattered dots in the middle, and an evanes. cent streak of somewhat dusky dots on the margin; the fore legs and antenna ringed with white; frequents gardens." Near London.

Tite Dotrid Brown (A. nebuter, Curts) occurs in gardens. Very similar to the foregoing, of which it is probably a mere variety. Wings seven-twelfths of an inch; first pair clotted and clouded with brown, with some indistinct dots on the upper duge, which are wanting in the preceding.

TथE Brren (A. Betulea, Curtrs). Wings seven lines one-haif, very similar to the last; the first pair slightly clouded with brown, and between the brown clouds oftentimes other clouds of a whitisl appearnnce, minute, and longritudinally disposed lengtliwise in the middle of the wing, as an indistinct and very much interrupted streak.

THE BLAeк Spzcklad Grzy (A. rhombella, StepHeNs). Wings seveu-twelfths of an inch; first pair ashy, clouded with black, witi a deep btack line on the base of the upper edge, and a brown one, but smaller, behind the middle of the upper edge; some black lines or dots on the dise, and longitudinally disposed in the form of a line. Uneommon. Near London.

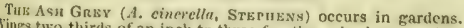
Wings two-thirds of an inch to three-fourths, eshy-brown, without marks, and rather glossy; all the body aslyy-grey, the palpi club-shaped, recurvate, and horned with bristly tips. Cambridgeshire, and near London.

The Sunctinerkous ( $A$, subcinerea, Curtis). Very similar to the last, but smaller and paler. Wings seven-twelfths of an inch, asliy-brown, and without marks; the first pair narrower, aud rounder at the tip. Oecurs in gardens, Near London.

Tne Char-colouren (A. lutarea, Cunts). Wings seven. 
twelfths of an incli to two-thirds; first pair pale reddish, with very few ash-grey dots, and in the middle two or three darker evanescent indistinct contiguous dusky dots.

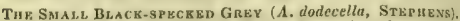
Wings five lines one-half to six lines; first pair pale reddish, with small dots disposed along the dise in pairs; then the upper, edge and the hinder margin finely dotted, or, as it were, splinklet with brown.

Tнв Rovar (A. aspera, Curtis) frequents hedges, Wings half an inch; first pair of a dull lead-colour, and almost smoke-black, with some scattered dots bcfore the middle, and an imperfect bandlet towards the hinder margin, black and some. what elevated, the margins more or less sprinkled or dotted with black.

THE Dotren GREY (A. Dfouffettella, StepIikNS) occurs in gardens. Wings six lines one.half to eight lines, with hoary lines or black dots. Variable. Very uncommon. Near Londus.

Tre Dusten Black (A. nigra, Curtis) frequents fardens, Wings nine lines to nine lines one-half ; first pair narrow, longivh, blunt, deep black, and slightly powdered with ash-grey or whitish; second pair black, with browuish fringes. Uncommon. Near London.

The WHite SHouldered WOOLLEN (4, sarcitella, Steprans). Wings one-half to three-fourths of an inch, ashy-grey, clouded with black; the head, corselet, abdomen, legs, and all the lower part whitish, and glittering in the sunshine like metal; antennx shorter; eyes black. Caterpillar found in garments, and makes rollers, in which it laps itself up in concealment.

Thе MLвv (A. Iacteell $t$, StERnENs). Near London.

HüBNER's (A. Hulmeri, Curtss). Wings five lines one.half; frst pair white or hoary, anteriorly clouded with black, with black clouds on the hinder part of the wing, which are more or less conflucnt. Not common. Near London.

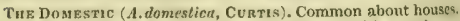
Wings five-twelfths of an inch to one-half, grey, with very large, longitudinal, deep black spots. Probably a peculiar species. Near London.

ThE BRINnled Brown (A, affinis, CuRtis). Very similar to the last. Wings five lines; first pair brown, with decp black dots, or four lines disposed in longitudinal rows; towards the hinder margin a narrow whitish bank. Probably a peculiar specieg. Near London.

Tuk Grfater Brinderd Brown (A. diffinis, Curtis). Resembling the last, but larger and darker; the wings six lines one. half; the first pair blackish, and slightly powdered with ash. grey. Very uncommon. Near London.

Tue Lrght Brinden Brown (A. contigun, Curtis). Wings half an inch; first pair ashy-black, whitish towarks the base, and with a white sleader band across, near the hinder marg in Near London. 
TIE BRINDLED BRown (A. sequar, Cuntis). Very closely resembling the preceding. Wings half an inch; more strongly clouded with black, witli two whitish bands, the anterior obligue,
and the posterior straight. Near London,

The Brautinul Baindede Baown (A. proxima, Cutitis). This and the two preceding are perhaps mere varieties, but possessing very different characters. Wings fve-twelfths of an inch; first pair grey, with a large deep black, angular, or waved, band-shaped patch in the middle, reaching from the upper edge neariy to the thinner margin, and behind this, some deep black clouds. Near London.

THe Tricozouren (A, tricolorella, Stephens). Wings half an inch, varied with black and red, with three white spots. The head black. Near London.

Tuz SAd (A. luctuella, Striprens). Near London.

TH: NEAT (A. decorella, Stepuens). Wings half an inch; first pair snow-white, with the upper edge interrupted, and a common streak; head snowy-white. Near London.

The Little B Lossom (A. subroser, Curtis). Wings five lines to five lines and a half. first pair deep black, with a large anterior somewhat rosy blotch touching the upper edgc in two places, and with an evanescent posterior purplish-white band, broken in the middle; second pair lead-black, shining, with brown fringes. About hedges. Not common. Ncar London.

Tue Beautiful Marmik (A. marmorea, Curtis). Wings talf an inch; first pair longish, or narrow at the upper edge, half black, but with an interrupted, white, oblique band towards the hinder margin; behind the middle two irregular red patches.
Norfolk, and near London.

TAв WHite-Dottrin Brack (A. guttifera, Curtrs), Wings five lines to five lines and a-half; first pair black, with two smatl white spots opposite to each other before, and two others behind, the middlc. Norfolk, and near London.

The little Blace ( $A$, atra, CuRtis) occurs on hedges. Wings five-twelfths to half an inch; first pair deep black; second pair black; head white. Variable.

The Short-Barred Wuth ( $A$. maculella, Strphens). Wings half an inch; first pair whitish, stightly sprinkled with dusky, mith a short, anterior, oblique, deep black band, that runs from the upper edge towards the thinner margin, but inclining forwards. Frequents hedges. Rather rare. Nenr Londow.

THв Iorsk-guok (A. Tremella, Stepuins). Wings fivefwelftlis to half an inch ; first pair snowy-white, or sometimes whitish, with a large black patch from the base to the middle, which, when the wings are shut, rescmbles a horse-shoe. In chalky districts. Kent, and near London.

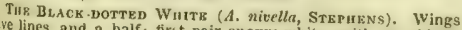
five lines and a half; tirst pair snowy-white, witl an oblong 
marginal at the base, black patch; in the middle an oblinue and black band, and towards the tip a small marjinal black spot; second pair ash grey. In hedges. Not abundart.

The Black Chouded ( $A$, aleela, Sthpuens), Wings five. twelfths to half an inch; first pair white, strongly clouded with black. Occurs about hedges. Variable. Near London.

The Brown Striak (A, intpronptella, Stepizns). Wings five-twelfths of an inch; first pair pale, or rather asliy, with s broat brown band, reaching from the base to the tip. Very rare. Near Iondon.

Tus TAwNy (A. fulvescens, Curtis). Wings five-twelfth of an inch; first pair somewhat tawny, or pale yellowish, sprinkled with very minute brown dots or clouds; second pair dark lead. colour and glossy.

Tire Fint-potted Brown (A. fusceseens, Curtis). Wing; four lines and a half; first pair brownjsh-prey, darker at the base and posteriorly, with about three indistinct brown dots in the middle.

THE Bhack Spotten Wuth (A. alternella, StepneNs). Wings six lines one-half ; first pair snowy-white, witl one or two black sjoty at the base, then a rather obligue hand, then a spot on the upper edge rather before the middle; then two oppo. site spots, one on the apper edre, the other on the thinner mar. gin, with auotherspot near the hinder margin before various deep black dots; second pair dusky, lend-coloured, and shining, with paler fringes. Very unfrequent. Near London.

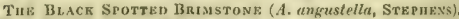
Wings five lines one-half to six lines; furst pair of a bright sulphur ycllow, spotted with deep black, and the upper edge faintly with deep black; the form of the spots variable. Rathel rare near London.

Tuk Whiтв-spotren Brack (A. albimaculea, StepuEx,i. Wings five lines one-half; first pair decp black, with an anterior white band, which does not quite reach the upper edge; a second band in the middle, which is slightly interrupted, and two somewhat opposite posterior white spots, one on the upper edre, and the other on the thinner margin. Perhaps a varicty of the precediug. Very uncommon. Near London.

Tul Four-spotreb (A. quedripuncta, StepinNs). Wings half an inch; first pair narrow deep black, with an indistinct yellowish spot near the bate, another conspicuous and wary across in the middle, and two opposite dots towards the hinder margin, one of which is on the upper edge, and the other near the thinner edge; sceond pair whitish, with the fringes darker. Very uncommon. Near J-ondon.

LOPHONOTUS (STEPHEN3).

TIa Minute Bunde ( $L$, fasciculellus, StEPHENS). 
Dovovan's : - emugrinellu, STEPHENS).

CHELARIA (MAWORTII).

THE LOBster-CLAWE') (C. rhomboidella, Stepnexs). WVings seren lines to seven lines and a half, all somowhat lance-shaped; first pair ash-coloured, with small black spots, and a large threecornered central one on the upper edge, with a black line nearly raching to the hinder margin; sceond pair brownish, glossy, vithout spots, and with broad fringes. Uncommon. Near London.

\section{RECURVARIA (HAWORTH).}

Tife Dincy Straw ( $R$. Silacello, Strpmsns?). Wings seven. twelfths of an inch to thrce-fourths, ycliowish-ash, with two very minute dusky lots. Uncommon. Near London.

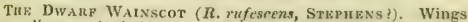
seven lines and a half; first pair shorter than in the preceding, and more blunt, of a uniform reddish colour, and without spots; sccond pair of a brownish white, with the fringes yellowish. Very rare. Near London. dion.

The Clouded Straw ( $R$. nelulellu, Steruens?). Near Lon-

Tue Bupf Straw ( $R$. ochroleucellt, StepukN'), Ncar Lon. don.

T'uk Lucu Straw (R, lucidellu, Steprens ?). Near London.

ТнЕ Ноок-тирев ( $R$. fulciformis, IIAwontu.) Wings halt an inch; first pair hook-tipped, ashy or greyish, with irregular, dusky, contluent lines or stripes on the disc, the fringes burntbrown; second pair of a dull lead-colour, and shining. Very uncommon. Near London.

\section{THE TINTEd (一, tinctella, StepHens). Near London.}

Tue Tinted Grey (- cinerella, Stephens). Near London.

Tur Brown=ooln (- unitella, Stephens). Occurs on hedgey. Wings five lines and a half to six lines, shining, snuff-brown, and without spots; second pair black; the head of a waxy yellow; palpi awl-sliaped, and recurved. Not uncommon. Near London.

\section{MACROCHILA (STEPHENS).}

TrE Long-winued ( $\boldsymbol{M}$. fusciellt, STHintins). Wings fivesixtlis of an inch; tirst pair red, with two darker indistinct bands, having an interjacent brown spot, the first nearly in the middle, and the second almost rectangular on the outer edge, and lying towards the lincler margin; second pair forked; an. tenne longer than the body; paipi of the male very large, and those of the female smaller. Very uncommon. Near London.

The Parintugsts (M, parenthesella, StBpuzNs). Winga 
twa-thirds of an inch, convolute around the hoty, narrow, brickred, each with a white longitudinal line running from the base to the middle; second pair dusky; legs all the length of its body, and palpi white. Found in grardens, Near London.

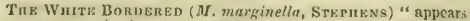
in summer, on juniper trees. Wings seven-twelfths of an inch; tirst pair brown, shining, with the inner and outer margin snow. white; second pair of a whitish colour, and without spots; yalpi clumsy, forked, internally snow-white, and externally brown." Near London.

Tux Licut Srrkak (M. birostelln, Stupnens) appears in summer, on clialky hills. Paipi Inng and brown; antenne shorter than the length of half the berly. Wings nine lines and a half, whitish, with a rather broad, longitudinal, dusky line at the outer margin, the margit parallel to the line snowy-white, two or three very minute black dots near the brown line on the disc. Near London.

Tut IWNed (M. aristella, Stipuexs), Doubtful as Mritish.

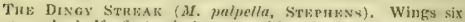
lines and a half; first pair brown, with a tinge of golden, with very minute golel-coloured specks, an indistinct black twin-spot before, and a second rather latger behind, the middle; second pair with their fringes deep black; two palpi large, hairy, conpressed, and club-shaped. Very rare. Near London.

\section{ENICOSTOMA (STEPHENS).}

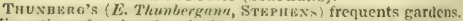
Wings three-fourths of an incli, wbseure, ahh-grcy, flossy in a very slight degree, with four deep black spots apprnximating in pairs, and banderl ; all the body brown, spotless. Not common. Near London.

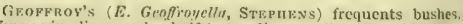
Wingrs nine lines and a half to ten lines, yellowish, with silver strcaks, ant two markinal sulphur-ycllow spots; antenne slender, flowny, and of the mirlde size; palpi very large, with the first joint longish, hairy, thick, and the last brown, recurved, white, Common. Near London.

\section{DASYCERA.}

Or.tvier's (D). Oliriellu, STrPHENi), Wings seven twelfths of an inch to two-thirls; firnt prair decp) black, sprinkled with very numerous gold-coloured dots, and having a large yellow patch at the base, and a broad central band of the same tint, be. hind the pateh and band is an indistinct silvery streak; second pair deep black, with the upper elke whitish nt the base; antemate black, white before the tip; bead deep black, and sitvery bripht ; palji large, recurved, y'ellow ; corselet deep black, with yellow. Common on hedges, near Joncion.

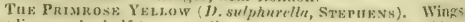
sis lines and a half to seven lines and a half, brownish goldell, 
with the base, and a larfe patch on the upjer edge, primrose-ycl. low, the tip of the wing whitish; palpi reflesed and horn. shaped; head and corselet primrose-yellow, and without spots. About hedges. Near London.

\section{ADELA (LATREILI,E).}

Lhtrent.e's Long Horn (A, Latreillella, Stepuexa). Near London.

Suitz's Love IlonN (A. Sulzella, Latrithin) appcars in Junc, about tuashes. Wings five-twelfths of an inch, bronzecoloured, with a polden band; antennae of the male thickicned as far as the middle; of the female very long. Very uncommon. Near London.

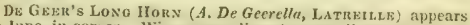
in June, in copses. Wings seven lines to seven lines and a halt; first pair blackish, streaked with golden-yellow, with a band crossing the middle, and edged on both sides with silvery black; antenna blackish, longer than the body, and so tenacious, that it is easily laid loold of by them. Near London.

The Coppen Japan (A. faseiella, Strphess). Wings sio lines and a half; first pair of a gold colour, shining, with a broad brown band in the middle; second pair golden-brown; antconte very long; lead and corselet black; and antennse of a midclle ize, with the head rust-brown; corselet golden. Very uncommon. Near London.

THe Scadious Long-norn ( $A$. ceprella, StFpnexs) apueass turing sunshine, among the flowers of the scabious. Wings six lines to eight lines and a-half, all, together with the frincres, of a luright somewhat copper-gold colour; second pair blackish-purple; head red. In woody places. Kent, and near London.

THE Grzen Lona-monn (A. rividella, STEPHeNs) apperes in May, in woody places. Wings six lines to six lines and a half: tirst pair shorter, more vivid, and glossy, of a greeniah-gold (w)lour; sceond parr brownish-purple, with a golden-green streak on the margin itself; all the fringes Eolden-green. Conmon. Near London.

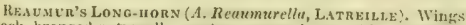
black, bronzed outwarkly; antenmse very long. white, black at the base, Near London.

I'w: Friscuian (A. Frischelln, StepHENs) apucars amonget fowers. Wings three lines and a laif to four lines, bruwnish. marple, and golden, with an indistinct contral spot : seecind pair tark purple, with a slight tinge of golden in certain peritions ; borly black, or deep-black; antemna longer than the budy, black, white at the tip, and becoming thicker dowuwards. Kint.

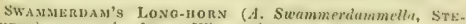
PHENs) appears in June. Wings nine lines to nine lines and a lakf, all hvid-ycilowish, without spots; antennre very long am whitish. Woody places, Near London. 
PdNzkn's Lono-norn (A. Panzerella, Steprens) appears the beginning of June, amongst woods, in chalky districts. Wings seven lines and a half, pale, very finely chequered with dasky, with streaks, scarcely observable by the naked eye; second pair ashy-grey; head tawny; antenne white, and very long. Searcer than the foregoing. Kent, and near London.

The Pale Brown Lone-Horn (A. Robertella, Stepuexs) ap. pears the beginning of Junc, about hedges, in chalky distriots. Wings two-thirds of an inch, lusky, spotless; antenux very long, and yellowish at the base. Merely a variety of the last. Very rare. Cottingham, and near London.

Tite Clouden Lead (-. Tortricell $\alpha$, Stephens) appears the end of February, near oaks. Wings three-fourths to five-sixths of an inch ; first pair lead-coloured, with brown bands and clouts, besides a band in the middle of the wings; which is inwardly oblique, when the wisgs are shut; second pair dusky. Aenr London.

The Crouded Brown (- nubilca, Stepirns) appears the cnd of February, about oak trees. Wings five.sixths of an inch; first pair hoary-white, with a narrow brown band near the hase, a second much broader behind the middie, and rather oblinte outwardly, bchind this the wings are ash.coloured, more or less clouded with dusky; second pair pale-dusky. Common. Near London.

\section{CAPILLARIA (HAพORT).}

Tre pale Cirecuered Brown ( $C$. Tesserella, Hawortu). Wings two-thirds of an inch; first pair brownish, chequered with palc, especially on the hincler part of the wings, with three pale spots on the upper edge towards the tip; antenna of middle size, and hairy. Very raxe. Near London.

THE PALE DOWNV.MORNED (C. pubicornis, HAworTH) appears ut July; wings seven lines anct a half; first pair pale and spot. less; sccond pair pele brown; antennx downy, and of moderate lcngth; head yellow. Uncommon. Near London.

Ture Rosy DAy (-. Salicella, Strpurns) "appears the end of fobruary. Wings cight lines and a half; first pair brownish, rosy zowards the upper edge from the base to beyond the niddle, with the upper edge entirely of that colour, a deep-black very straight band before, and a similar one bchind the middle, which almost touches the thinner margin; second pair brown, with the fringes brown; palpi short, turnished with long rosy hairs. Uncommon." Near London.

Tue Autumat. Dagger (-, gellatela, Strpuens). "Wings freyish-brown; the primary ones with a white fillet. This species is found in fruit gardens in October; the female has obly very minute wings." 
Tan DRA Day (-. Phryganella, Stepuens) "appears in November. Wings five-sixths to cleven-twelfths of an inch; first pair rather long, iron-brown, in good specimens a palish interrupted, and very indistinct streak from the base behind the middle; second pair deeper brown, with the fringes rather paler. Coombe Wnod,"

DIURNIEA (HAWORTH).

Tü MARen Dagorin (D. Fagella, IIAworth) "appears is Miarch, on the trunks of birch trees. IVings of the male one incl nue-twelfth, fomale seven-twelfths of an inch: in the male grey, with an anterior and posterior streak, and central brown duts; in the fomale, first pair lance-shaped, darker, and sprinkled with brown. Common." Near London.

ThF Novbarer Daggkr (J). Novembris, Stefiriens) "appeats in November. Wings of the female seven-tweifths to two-thirds of an incli; all the wings acutely spcar-shaped; first pair hoary, with a deep black interrupted streak from the base to behind the middle, then a band anteriorly oblique when the wings are shut, decp black, and connected with the streak; before the band the wings whiter, with two contiguous, deep-black, loneitudinally disposed dots; second pair whitish, with the tips rather darker. Very uncommon." Near London.

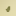

\section{EPIGRAPIIA (STgPHENS).}

\section{Tuz Finkirt ( $E$. Avellanella, Stepuens). Near London.}

STwNKFLNkr's ( $E$. Steinkclneranu, STEPHENs) "appears the eni of March. Wings five-sixths of an inch; first pair anteriorly ash-culoured, with a broad wary deep-black line in the middic of the dise. $\Lambda$ bout hedges. Not common." Near Loudon.

\section{MELANOLEUCA (STKPHENS).}

THE Twin SPot Enank (M. Echielle, STEHIENS).

Thi Growwell (M, pusiella, Stremens). Near London,

The Scarce Frmine ( $M$, dolecera, Strpilzns). "Wings seven lines and a laalf; first pair lead-coloured, witl about twelve rather large and somewhat regular black dots. Very rare." Near London.

TuE Funbrral ( $M$. funerella, Sternens). "First pair of wings pure white, with two large, contiguous, posterior black patches, two black spots towards the base, and two patches on the upper edge at the base. Very rare." Ncar London.

\section{YPONOMEUTA (FARRICIUS).}

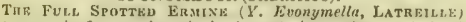
"appears in June and again in Aurust, in gardens and about herlges. Wings ten lines and a half; first pair white, with four or five deep black dots disposed lengthwise; beneath, and the 
sceond pair on both surfaces, lead-coloured; head and corselet sprinkled with black dots; belly underneath white, above black; antenna bristle-shaped ; legs with spines. Cuterpillar tregari. nus, yellowish, with dots on the sides, Not common." Near I. ondon.

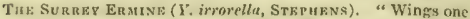
inch ; first pair dull white, posteriorly with a large rust-brown patch, and numerous irregular decp black dots. Not common." Surrey.

TIf: FEW-Spotted Erjine ( $I$, rovella, Stepeens). "Wing, three-fourths of an inch, snowy-white, with about twenty black dots, generally arranged in regular rows. Norfolk."

Tur Common Ermine, (Y'. pradella, Latreiner) "appears during summer about hetges and pardens, Wings tive-sixths of an inch to one inch; first pair with aloout thirty black spots; second pair always of a lead colour, with thick fringes. Very common." Ayrshire, and near London.

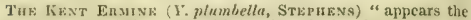
cod of dugust. Wings two-thirds of an inch; first pair leadcoloureti, with a large distinet spot in the middlo, numerous dots, and the tip brown. About hedges," Kent.

Curth's Eratoe (V. Curtisclla, Strphens). "Wings two. thirdy of an inch ; first pair snow.white, sprinkled with dusky nt the ha $\approx c$, with the upper edge black from the base to the middle, the black dilated into a short three-cornered band in the middle of the upper edge; the hinder margin snow-white, with black confiucnt spots; second pair and all the fringes brownish leadcoloured. Not common." Near London.

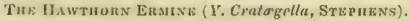

TuE Smat., Brown Bak ( $Y^{\prime}$, ambiguella, Sternens). "Wings six lines and a half; first pair yellowish, with a lroad, perfeet band in the midtlle, indistinctly dotted with brown, and dilated towarks the upjer edge; second pair dim white, fringes silky, and yellowish. Very rare." Near London.

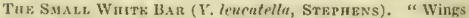
six lines to six lines and a half; first pair black, the anterior band whitish ant semicircular, anteriorly transverse, and posteriorly roundish, the hinder bard narrow and white, but spotted ; lical quite white; palpi retlexed; antenna black, and ringed with white. Occurs on hedges, Rather uncommon." Near Iondon.

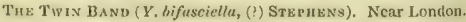

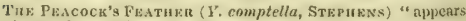
dutiug spring. Wings six lines and a half; first pair narrow, arh-coloured, witls a copper-red terminal spot, somewhat eyelike, and having a brown iris; fringes burnt-brown, but toward the posterior angle pale brownish; second pair pale brown. Common." Near London.

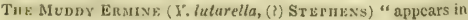


spring, about hedges. Wings five twelfths of an inch to seven. twelfths; first pair yellowi-h-n4h, with mumerous clarker, inclistinct dots; near the tip of the upper edge a small slender white line, the fringes, in yarticular positions, of a copyer-colour; sccond pair pale brown." Near London.

Tuz Sma l. Banmen ( $Y$. subfasciella, StemutkNs). Near Lon. don.

Tue Purpez-ndeen ( $Y$, Carsicllu, Stepraxs). "Wings five lines to tive lines and a half: first pair ashy-brown, with larker dots, the fringes and hinder margin purple; sccond pair whitish, pasteriorly brown. Not common." Coombe IVoud, and sinrey.

Tuk Long-wavern Wmite Back ( $l^{2}$. semifusen, Strantens). "Wings half an inch; first pair narrow, brown, witl a tinge of purple, a common broad white streak, intersected it the middle by a short and straight brown basd, the upper cdipe with white dots, fringes very deep. Very unfrequent. Noar London."

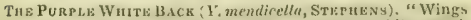
five lines and a half, ashy-brown, with a common white streak intersected in the iniddle by a short straight brown squarc band, the npher edge thickly dotted with wlite. IIedges." Near London.

Tuk PURpln Wark-4truak ( $Y$, ubistriu, Stermpxs). "Fre quents woody places. Wings four lines and a half, tawny-purple, with a common snow-white autcrior streak. Variable." Near London.

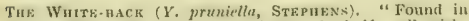
gardens. Wings five lines to five lines and a half; jellowishgrey, with a common broart white streak, eut in the midkle by an oblique purplisls band; the upper cdfe of the first pair of wings dotted with white, Common." Near London.

Tuz Four-footer, ( $Y$. ictrapodella, Strepis eNs). Near London.

The Evilet $(Y$, oceller, Stramins). Near London.

The Litri.e Exelet (Y. suborellea, Sterinens). Near London.

Tre Creas-colouren ( $\boldsymbol{Y}$. osser, Steptens). "Winge tivetwelftlis of an inch; first pair spcar-shaped, whitish, milk wi bune white, and of a silvery hue, with a short ycllowish strige at the base, and a very slewter onc, (in good specinens) in the middle of the thinner matpin, fringes burnt-brown ; second pair, spearshaped, dusky, lead-eoloured, very flossy, with very broal fringes, and of one colour; the hinder margin of the first pair, iu certain positions, is snowy. white. Very uncommon." Near Lendon.

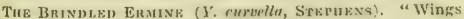
five-twelfths of an inch; first pair pure white, slightly sprinkled witl dusky, with a common arch aud hinder margin of the same colour; second pair alway's sjear-shaped, dull lead-coloured, and very glossy, with deep fringes. It frequents osicrs." Near London. 
TuE Banren Wuts ( $Y$. Clematella, Strpukns), Wings half an inch; first pair snowy-swlsite, with a brifht, black, marginal line at the base, in the middle an oblicue and angniar black band, the ip with one or two black spots; second pair ashy, spotless; head brown; corsclet snowy-white. It frequents hedges. Not common, Near London.

\section{ARGYROSETIA (STEPHENS).}

GonarT's (A. Guedartella, STEPIIBNS) nppears in July, on the white beech. Wings five lines to five lines and a half, silvery. gold, with the characters I V T gold-coloured, band-like, and equi distant. Abundant. Near London.

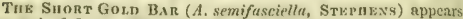
the end of June. Wings half an inch ; first pair silvery-golden, with three short, pale, gold-coloured hands in the thinner margin. Very uncommon. Coombe Wood. Surrey.

TIE Goun I W (A.I W-ella, Strvrivs) appears in Juty, Wings five lines to five lines three-fourths; first pair silvery, with a golden band near the base, and thicker towards the upper edge, behind this, from the middle to the hinder margin, thick connected bands, representing the letter $W$, and a silvery spot in the tip; sccond pair lead-coloured, with the fringes dull. frolden; head and corselet snowy-white. Occurs on the white beceh. Abundant. Coombe Wood, and Suricy.

Tuv Gom I V (A. I V.ella, Strmens). Wings five lines and a half, of a silvery huc, with the characters $I V$, of a gold. colour, band-like and connected. Very rare. lient.

THn Grikn-I.kTtren Goun (A. literella, Stwpuns) appears in July, among beech trees, Wings five lines thec-fourth, silvery ; the first pair with a tinge of golden, with three short, equidistant golden bands, the first near the base, representing the Greek Iota, the second in the middle, \& Upsilon, and the third at the posterior angle, a large Omera. Very rare. Darenth Wood, Kent.

TuE Goldon Rinnavis ( $A$, murivitella, Stephens). Wings five-twelfths of a line; first pair very shiniug, silvery, with a larpe, very much waved, folden-red fllet from the base to the erlye, occupying all the wing, with a silvery spot at the tip: sceond pair dusky lead-coloured. Very rare. Near London.

The Gotakn Band) (A. aurifusriella, Stupuens?. Near Londion.

\section{ARGXHOMIGES (CURTIS).}

HIANCARD'; (A. Bumcardella, CuRTIs) appears the chil of May, on hedges. Winges three lines and a half to four lines; first pair golden, glassy, the base with a longitutinal silver line, which joins the edge to the corselet, four spots at the thicker margin, three silvery at the thinner maigh, all behind the 
middle; second pair very hairy, sllvery, and without spots; antennat above brown, bencath silvery; corsclet gold coloured, with a silver border. Uneommon. Near London.

S'HREнав's ( $d$, Sehreberelli, Curris) frequents hedges, Wings one-fourth of an inch; first pair gold-coloured at the base, with two silvery bands in the middle, and two opposite spots at the tip, of the same hue; second pair ashy.grey; the legs glitter with sllvery shades; body small, but very brilliant. Rather scarce. Near London.

The Brioht Specklen Gord (A. Cydoniella, Curtst) freyuents hedges. Wings one-fourth of an inch, first pair of a golden colour, with \& pure white line at the base, and cight spots ou the maryin, disposed in pairs, and of pure whiteness. Varjable. Uncommon, Near Chelsea.

KI.EMAN's (A. Klemanella, CurTis) appears the end of Mry, ahout hedres, Wings three lines and $\mathrm{a}$ half, of a gold colour, glossy, with two perfect anterior silvery streaks, and two posterior, interrupted in the middle, and gencrally uniting, a deep black terminal spot. Not common. Coombe Wood.

Tun Sizvan Srotrin Goln (A. Mespilella, Cunts) appears the end of May, about hedges. Wings one-third of an inch; first pair golden tawny, with a very slender silvery line in the middle of the base, and seven comma-shaped silvery marginal dots, the thinner margin sprinkled with silvery as far as the centre. Common. Near London.

R.uv's (A. Rayelli, Curtis) appears the end of May, about hedges. Wings one-fourth of an inch; first pair dusky-gokden, spotted on both sides with three white and three silvery spots. perhaps a variety of the last, but much smaller, and the wings nearly without the tawny or golden colours. Common.

TuF TranhE Gold Strup (A. tristrigella, Stepunss) appears the end of May. Wings three lines and a half; first pair tawny-brown, with a straight silvery-golden band before, and a second in the niddIc, and those behind the middle all equidistant; sccond pair dull lead colour, with elevated fringes. Very uncommon. Near London.

TIE TAWNY TIEBLE BAR (A.trifascidla, CuRTIS) apperts the pnd of May, on hedges. Wings three lines three-fourths; first pair dull tawny, with three somewhat straight, equi-distant, brown bands, whitish-golden on the outer edges, the first before, and the second in the middle, the third behind the middle and forked at the yosterior angle, the tip with a brown, oblong, band-like patch; second pair dull lead-coloured, with very long fringes; the head tawny, with a snowy-white forchead. Rare. Coombe Wood, and Surrey.

Myluen's (A. Myllerellu, Sterness). Supposed to be British on doubtful authority.

Harris's (A. Harisella, Curts) appears in May ant June. Wings three lines three fourths to four lines three-fourths, 
varied with golden and silvery, blunt at the tip), the tip itself of a brownish burnt colour, with a reep-black eyelike spot, Com. mon about bushes. Near London.

Craser's (.1. Cramerallo, STHPHENs) feppars the beginning of May and June, Wings three lines three-fourths, silvery, rather glossy behind the micklle, with three opposite obligue lines on both sldes, and a decp black eye-like spot in the tip. Common. Near London.

Tiz: Poncenarx (A, hortella, STwPHENs) appears the end of May, nowut bushes. Wings one-third of an inch; first pair snow.white and glossy, with three yellow bands, the third inter. rupted; the tip is terminated by a black line; head small aud snow-white. Near London.

THa Dark Porrelain (A. sylurlli, II a worti) appears the ent of May, in woody places. Wings three lines three. fourths; first pair pure white, with a band at the base, comwosed of two or three hrown streaks, scattered over with ashy. feTcy, a band nearly in the midclle, rectangular, asliy-grey, and fistinctly margined with bown, then with a josterior asiy. frey crosis from the base to the thinder maryin, indistinctly bordered with brown, also at the tip a minute asliy frey cyelet, with a brown iris, and deep-black, oblong, longitudinal pupil; second pair ashy-white. Uncommon. Near Loudon.

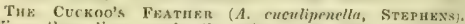
Wings turee lines one-fourth to four lines; first pair hoarywhite, with three or four obligue and somewhat equi-distant brown spots on the upper edge, and two or three others at the thinner margin, the tip with a small black stripe; second pair ashy-white. Uncommon. Coombe Wood and Sturrey.

THE IIAzEL RED (A. Corylifolipllo, CuRT19) appears the end of May and June, Wings one-third of an inch; first pair reddinh, with a very slender yellowish line from the bave to the middle: then two opposite marginal ones in the middle, obliquely confluent, and forming the Greek letter $y$, and bchind this letter one or two nifute and palc lines; second pair brown. About hedges. Common. Near London.

Tuz Aluer Lenp (A. Alwifoliella, Stepukns). Near London.

Tне Sомпте (A. olacsurella, StвpHzNs). Near London.

Tuk Run AxD Wutr B.x (A. rufipunctella, STEPmExe) appears the end of May. Wings thrce lines and three-fourths; first pair ashy-grey, with abnut three equi-clistant bandlets, the first anterior and very indistinct, the second in the middle. composed of a white spot, a black one, and another red, more or less connected together, the third is towards the hinder margin, and very similar to the second; second pair dult lead-coloured. Very rare. Kent.

HERIBEIA (\$TEPHENS).

II.tworth's (II. Haw'orthellu, (STIPIENS). 
The Groundet ' $H$. humerell, Sceprexs). Near Loniton.

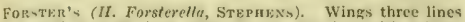
and a lialf to threc lines three fourths, flat, browni-h-golden, potless at the base, with a common arch in the middle of the back, aud behind this five marginal silvery streaks, the tip with a deep-black patch containing a silvery sjuot. Very uncommon, Kent.

THF Simprez (H. simpliciella, StepuENs) Ncar London.

TH Coonsti ( $H$, cognatella, Stepinss).

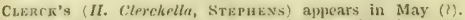
Wiuts one fourth of an inch; first pair silvery, golden-brown at the tip, somewhat streaked, and tailed with a (teep-black round eyclet. Near London.

the Cukrty Lhip, ( $\boldsymbol{H}$. nivella, Sternens). Near London.

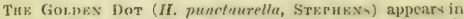
June (?). Wings three lines three-fourths, all silvery; fir t yair with seven obligue, brown, posterior lines, radiatiug ennjunetively in the tip; of these the first four are syrinkled with goldcotour : at the posterior angle a convex gold-coloured dot, which, in some situations, scems half black. Common. Coombe Woud, Surrey.

THE: Single Dot (II. unipunclella, Stepisena). Near Lon. don.

Tut: MALLow LeAp ( $I$. Semiuurellu, Stepuexs.) Neat london.

\section{MICROSETIA (STEPUENS).}

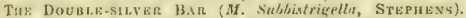
Wing, tive lines ene-fourth; first pair black, with a linear but before, and a sccond interruptesl behind the middle, both straight, snowy-white, or rather silvery ; second pair black, with lonk, thick, brown fringes. Very rare. Near London.

THE INDistact ( $M$. obsoletelli, Stetursa). Near London.

Tus Mrnute (M. exignella, Sripnevs). Near London.

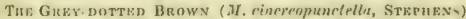
appears the end of hay, on bushes. Wings three lines threefourths, all black; first pair with an indistinct ashy banellet, extending from the upper edye nearly to the thiuncr cetge, and an indistinct a-hy. $\mathrm{Fr}^{2} \mathrm{y}^{\prime}$ s jot at the posterior farmle, and another at the tip. Kent.

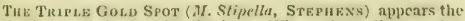
end of August in woody districts. Wings tluree line's and a latif; tarst peir brown, with three large brillinut gold-coloured dots disposed triangularly, one in the midelle of the thinner margin, the otlier on the upper edge. Very rare. Kent.

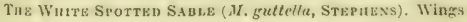


one third of an inch; flrst pair shining, black, or, in certain positions, pitch-black, with four opposite marginal suow-white spots, the two anterior are confluent in a band before the mid. dle, the other two are behind, andmore remote; second pair. and all the fringes, black; head ycllow; tail ashy-grey. Found with the preceding.

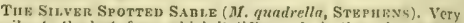
similar to the last, from which it differs only in the colours of it, head and spots; the head is white insterd of jollow, and the spots silvery and more distinct, instead of snow-white. Uncom mon. Kent.

THE Sulver-Blotched ( $M$. sequella, Stermins). Wingsthree lines one-fourth; first pair deep black, with a broal band hefore the middle, on minute spot in the middle of the inner marrin, and a large spot towards the hnder part on the upper eclge, and posterior tots, all pure white or silvery; second plair brown. ish. Occurs on hedges. Near London.

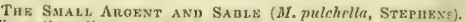
Wings three lires one-fourth; first pair very deep black, with a broat white streak at the base of the thinncr margin, with a splendid silvery straight band in the middle, and joined to the streak, and with two obliguely opposite and silvery dots, one on the thinner margin, and the other on the hinder part of the upper edge; sccond pair whitish, or rather pale-coloured; head and vent beard white; body deej, black. Very uncommon. Kent.

The Small Doubiz Siugr Bar (M. nimrella, Strphnss) frequents bushes. Wings three lines and a half; first pair black, with a sllvery band before, and another slightly interrujted be. hind the middle; sccond pair shining, and clull lead-coloured. Uncommon, Near London.

Tue Cream-spotted Sable (M. trimaculella, Stepnens) appears the beginning of July, frequents poplar trees. Wings two lines three-fourths; first pair deep black, with a very broad tip notched yellowish streak from the base almost to the middle, and with two posterior, opposite marginal, nearly confluent, yel. lowish spots. Very raxc. Near London.

The Twin-spot SABLe ( $M$. subbimaculella, Streprens) occurs about hedges. Wings two lines anti a half; first pair deep black, whitish at the base, with two obliquely opposite, ncarly contlu. ent, silvery spots, onc of them is in the middle of the thimner margin, and the other in the anterior part of the upper elge; second pair lead-black. Near London. don.

The Buack lirinae (M. nigrociliella, Strphras), Nert Lon-

Thr Sirven-namred Brown ( $\boldsymbol{M}$, unifasciella, Sternevi). Wings three lines and a half; first pair pale dusky, witi a straight silvery lrand just behind the middle; second pair brown, with the fringes on both sides very deep and pale brown. Very rare. Near London. 
The Central Suyer Ban (M. medinfusciella, Sterinens). Hings two libes and a half, very similar to the last, but smaller; the first pair of wings deep black, with the band in the middie of a more silvery huc, and, in some situations, very slightly inter. rupted; second pair broader than in the foregoing, darker or lead-black. Very rare. Near London.

TIE Dramond-Baraed Pyemy (M. aurella, StepHens) appears in summer. Wings one line one-third to two lines onefourth, of a very brilliant gold-colour, posteriorly decj black, with a silvery hand; second pair deep black, with a very bright silvery streak; head white, with the forchead rust-brown; antenna short and black. Chelsea.

The Pygmy Sulver Bar (M. posticella, Strphens). Wines two lines and a half; first pair of a brown-silvery silky hue, with a straight posterior silvery-gold band from the upper edge nearly to the vent angle, and behind this, in some positions, brownish, with a purplish tinge, second pair very pale brownish. Very rare. Near Londox.

THE Violet Pygsi ( $M$, violnceella, Strpans). Wings onefourth of an inch; first pair deep black, with a tinge of violet; head rust-biown; antemine very remarkable, strong, short, somewhat neeklace-formed, covered at the base of the head with a plate of white. Very rare. Near Londou.

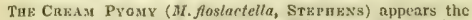
end of May, about woods and hedges. Wings one-fourth of an inch; first pair very pale-yellowish, with a larke, irregular, band-like, deep black patch in the middle, and another terminal, roundish, deep black tinged with violet, extending from the apper edre to the thinner markin, fringes yellowish-white; second pair lead-brown, silky, with very deep lead-coloured fringes on both sides. Near London, and Surrey.

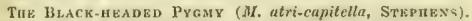
Wings two lines three-fourths; first pair of a gold-colour, with the hinder margin strongly tinted with purplish, the upjer edge, in some situations, reflecting a purplish liue; the liead is very deep black, and markerl witi a plate of white at the base of the antennze. Uncommon. Near London.

TuE Ren-maden Pramy ( $M$. reficapitellu, Stemens). Wings two lines three-fourths; first pair of a gold-colour, with the linder margin purplish; the lread reddish. Near Loudon.

THE Lrsst Prowy (M. phgmaellu, STrpunss) frequents hedges, the smallest of all the Lepidoptera. Wings one line three-fourths to two lines and a half, anteriorly of a jule-gol. den tint, and the hinder margin indistinetly tinged with purplish; the head reddish. Not common. Chelsea.

THE SATIN PYomy (M. sericiella, Ste PHFNg) appeas the cad of May. Wings three lines oue-fourth to three lines and a half, all of silken glossiness, and browaish-silvery hue ; first pair, in some positions, with two small spots or dots, which are three- 
cornered, paler, or whitish; one before the middle, and the other in the midule of the thinner margin. About liedges, Common. Coombe Wood, and Surrey.

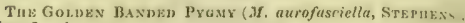
Near London.

Grzicut's (M. Gleichella, SrEmunes) occurs on bushes. Wings three lines threc-fourths; first pair flat and decp black, glossy, with a broal silvery band in the middle, and two oppo. site spots of the same colour towards the tip ; second pair ashcoloured. Uncommon. Near London.

T1E Foun-spotten Gon) ( $M$. quadriguttella, StrphiNs) appears the end of May, about helges. Wings four lines onefourth; first pair of a golden-copper colour, with two rather large, obliquely opposite, and beautifully brilliant golelen spots, which are often joincd to an anterior somewhat arched band, two other very similar spots, but distinct, larger, three-cornerce, obliquely opposite behind the middle, one at the upper edge, and the other at the thinner nargin; second pair brownish. Verr uncommon. Near London.

\section{OECOPHORA (LATREILLE).}

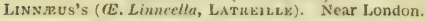

RaseL's (E). Resella, LATREILLF). Wings fire-tweifths of an inch; first pair ytllow, with an oblong black patch at the hase, and a black band across, nine silvery spots near the margins, the outer and inner margins black: the black in these wines, in some positions, is changed into a very glossy silvery; boty black, Very uncommon. Near London.

Son.tEFER's ( gardens. Wings four lines one-fourth, black, ycllow on the dine, with a streak, and two longitudinal lines, and three spots sil. very; bouly bright silvery. Near London.

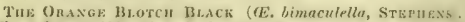
Wings five-twelfths of an inch, narrow, and jet-black ; first pair with two large, oblong, somewhat oval gold coloured spets on the dise, longitudinally disposed, the anterior extending from the base to the thituer marain, and the pesterior more distinet on the margin; second prir deeply fringed. Very rare. Near London.

Tue Noxparil. ( $(E$, mimin, Strpuess), A most betutifu! species. Wings five-twelfth of an inch; first pair excectingly Iniliant, with a broad variable band at the base, which is some. times golden, sometime's deep-black, and strongly terminated with black, then in the middle a threc-cormeicel wider band at the upper edge, of a (lecp golden hue, very solict, margineal (su hoth sides witli a -lenkler devpl-black streak, and with a change. able bandlet, which is sometimes of a rich guld colour, or coupery, coppery-red, or violct, lehind these the wings are jet-black, with a very bright variable streak from the thimner margin to 
the tip, sonetimes silvery-blue, volet, or volet tinged with $\left.f^{e}\right)$ ld, the fringes deep and black; sceond pair brown, olossy, with very decp brown fringes. Very rare. Near London. On hedges.

The Mistalic (E. metullello, Stepuevs), Near Lonton.

\section{PANCALIA (STEPHENS).}

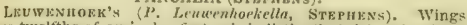
five-twelfths of an inch; first pair indistinctly brick-red, with a black band towards the base, another in the middle, a cross black patch at the posterior angle, an oblique line before the tip, the black changes into a silver colour, the wiags have very large fringes. Very rare. Near London.

Tuk Brown Brassy ( $P$. fuscoanea, Sturuwxs), Wings seven-tweliths of an inch; first pair brassy-brown, shining, with a coppery tiuge; sccond pair dcep-black and shining. Near london.

TuF Brown-coprer ( $P$. fusco-cuprca, Stapirwas). Very similar to the last, but smaller. Wings five lines and a half; first pair brown-copper colour, spotless; sccond pair brown, and shining. Very uncommon. Near London.

Mkriav's ( $P$. Meriunellu, STExusws). Wings half an inch, black; the thinner marfin terminated with hairs; thrce cross vilvery lines, with a large black interjacent spot; the midele line is forked towards both extremities. Yery rare. Near London,

TnF Wutте-spotrud Brown (- gutter, Stephevq) frequents woody places. Wings five lines and a lalf; first pair black, with three or four equi-distant white spots on the upper edre, and two alternating in the middle of the thinncr markin head tawny; abdomen brown, yellowish at the vent Larb. Very uncommon, Near London.

Fukiву's (-. Fyestella, StrpuEns) appears in summer. Wings five lines and a half; first pair of an indistinct fold colour, posteriorly with five silvery streaks, of which the last three are short, and do not reach the thinner margin; at the vent angle a cross-cleep black patel, with three very lively silvery dots, and at the tip of the wing another deep black spotless pateh; second pair ashy-grey, spotless. Not common. Near London.

The Brown Coppla (- Nrrlebella, Strphens). Wings five lines and a lialf; first pair of a dull-browis copper colour, spotless, but with the hinder margin, in particular positions, duskypurplish; second pair black; the fringes in all the wings brows. Very rare, Near London.

Tнқ Brown Grene (-, fusco-viridella, Steruens). Wings fre lines and a lialf to sis lines; tirt pair shining, of a dull. brown green, or brown-golden, without spots or dots. Common Near London.

THE SILVER-barRLD SABle: (- cinctellu, Stertens) aphears 
in summer. Wings five lines three-fourths to six lines; first jair oblong, deep black, in the middle a snow-white band; second pair bristle-shaped, fringed; antenne waved with white. Frequents hedges. Uncommon. Near London.

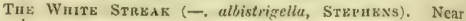
London.

The Griat Raven Frather (-. grandipennis, Stepunvi). Wings cight lines and a half, shining, black or blackish; antent. nze of the same colour. Very rare. Near London.

Tug Pye-zentuer (-, Pica-pennis, Stuphens). Wings five lines and a half, all decp black, and sluining; first pair with an uncqual, strons, interrupted white band in the middle. Norfolk. Near London.

THE Bupp-B Lotcued (- cylindrella, Stepnens). Wings seren-twelfths of an inch; first pair longish, linear, incumbent, brown, with three large, oblong, yellow spots; wings under. neath yellow; legs yellow, tinged with brown; body longish; head yellowish, with the antenna "whitish; corselet brown, with the back yellowish. Frequents gardens. Near London.

The Crow Feather (-. serratella, Steptens). Wings paler than in the Small Raven Feather ( - . Coracipennella.)

Tuz Small Raven Feather (- Corucipennella, Stephexs) found in grassy places. Wings half an incli, all black and shin. ing; the antennae ringed with white. Near London.

The Brown Featier (- obsezrelln, STEPHeNs) found in Frassy places. Wings half an inch, all brown, shining, and spotless; fringes brown; antennac ringed with white, but decper and more perfect than in the preceding, of which it is perhaps merely an otd and faded specimen. Near London.

THE Vultura Featurr (-Gryphipennelle, Strphens) found amongst grass. Wings five lines and a half to six lines, glossy; first pair dull-red, with the upper edge, in some positions, of a deeper red; sccond jair brown. Near London.

The Shining Ciay (-, lutarea, Stephavs). Frequents bushes. Wings five lines and a half, yellowish, golden, shining, spotless. Near London.

THE Bupp-FeAthei (-, ochroleucelli, Stempnens). Near London. don.

The Buach FaAtier ( - , nigricella, StepunNs). Ncar Lon-

THE YErLOW-frLAdED BuACK (- favienput, StePHEvs) appears in July, about hedges. Wings half an inch, all deep black, shining, spotless; head reddish yellow; tips of the palpi yellow. Near London.

Tuk OnLono Golb-riean (- scissella, Strpilnvs). Wings five lines one fourth; first pair oblong, dull faint gold-coloured, 
with the upper edge, a streak in the midd $e$, from the base to the end, and another very similar towards the thimner margin, brown or black; in the middlle of the first streak a black dot or dash, confluent at the upper edge; second pair spcar, shaped and brown, with brown fringes. Coombe Wood, Surrey.

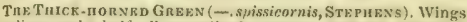
five lines and a hall, all exceedingly narrow, spotiess, and shining; first pair golden-green; seeond pair brown; antennse, in botli sexes, but more remarkably in the male, thicker at the bot. tom part; the hairs are strong and closely pressed. Near London.

The Trevon, Gren (-. Trifolii, Stepnens). Near London.

\section{PORRRCTARIA (HAWORTH).}

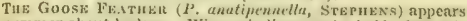
in sumner about liedges Wings six lises aud a half; first jair pure white, with the tuper edge slightly, and the hinder margin lroadly, tinged with black; second pair taint brownish, head pure white; antenna white, dinged on the upjer parts with black. Near London.

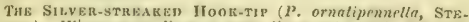
p!Invs). Wings seven lines to seven lines and a half; first pair hooked at the tip, yellow, very narrow, with various silvery lnes, and some black; second pair linear, spear-shaped, with very loug dusky fringes. Very uncommon. Near London.

THE SILVER-STrk, KED ( $P$, ochrea, Srepuens). Wings nine lues and a half, narrow, somewhat tailed, ycllowish.brown; frst pair with two very indistinct stripes consyicuous in certain positions, silvery, and excecdingly slender; the first obliquely drawn trom the base to the posterior angle, and the second at the thinner markin shorter than the first; second pair brown, shining, linear, spear-sliaped, with the fringes very long ant brownish. Very rare, Near London,

THE Cock's Festria ( $P$. gallipennella, StвpHens). Tound on grass. Wings six liues and a halt to seven liues; first pair redtish, with the upper edge and thinner margin whitish. Variable, Near London.

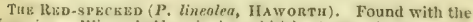
foregoing. Wings lialf an inch; whitish straw-coloured, with the wing ribs interrupted, reddish. Near London.

THE WHITE-EDGED ( $P$. allicostre, H + worTII) appears the beginning of July. Wings five lines and a half, acute, red, with the بpper edge and two periect, contiguous, very slender, stripes, white; sceond pair brown. Near Croydon, surrey.

The LEsD-Colouisn ( $P$, leucrpennclla, STEpirens). Wings four lines and a half to five lines and a haif, very acute, whitish lead-coloured, with theupper edgeslightly whitısh. Near London.

Tue Aromprive ( $\boldsymbol{P}$. argentula, Sterinens). Near London. 
Tiz Aurotixe (- auritella, Stephens). Near London.

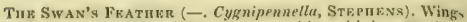
four lines and a half, and fringes pure white, shining, spotless. Very rare. Near London.

The Dвm wate (-, semialbella, Stephens). Near London.

Thв Treale Atos (-, triatomea, Strinuns). Wings threo lines and a half; first pair snow-white, with three josterior black dots, disposed in a triangle, two longitudinal on the dise, and the third alternating at the posterior anele. Very rare.

THE Creat.coloumen (- floslactis, Strpuf:Ns). Wings one. third of an inch; first pair and fringes faint yellowish; scernd pair brown. Very rare. Near london.

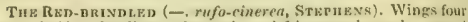
and a half to five lines; first pair and fringes ashy red; secoud ajrentirely brown. Near London.

Tun Lucidine (- Iucidella, (Srepinens). Near London.

The Sand. Suinino Brown (- Oleela, Strpuras). Wings three lines and a half to four lines, all entirely browmish, shining, spotless. Perhaps an aged variety of the Red-brinelled. Near London.

THк REv Fratrer (- rufipennellu, Stornans). Wings onethird of an inch; first pair red, duller towards the tip; secont pair brown. Ilead red. Occurs in grassy places. Near London.

The Fulvescentink (- fulvesens, Stephens), Near Lon. don.

THE Bordered STRAW (-, margined, Steptrens). Wing, three lines and a half to four lines; first pair deep straw-co. lotured, spotless, posteriorly bordered with brown. Near London.

Tuh Tamny Crescent ( - Lambdella, Stepunns). Wings six lines to seven lines and a half; first pair briglit tawny, spotle - , except a strong, cominon, crescent-shajed, deep black spot just behind the middle. Unconmon. Near London.

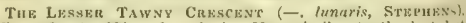
Wings five-twelftlis of an inch. Very similar to the last, but smaller, and with the crescent-shaped spot more inclistinct, 8 nd oblique, and the linder margin darker. About ledges, Cont. mon near Chelsea.

Tuz Lutanine (- latarella, Srmpuns). Near London.

The Saturatine (- saturatellu, Stapnfas). Near London.

THв PANzentne (-. Panzerellu, Strpinss). Near London.

THк YkL.ow I1кAл (一. flavi-frontella, ILworтu), The first pair of wings ashy-grey, spotless; the head tawny. 
TINETD N (STEPHENB).

GALLERIA, (FABRICIUS),

THE Honey (G, alveurin, FAntetus). Wings of the male two thirds of an inchi, female five sixths of an inch; all the body and wings ashy-grey, spotless; head hairy, tawny. Caterpillar feeds on the honcy of becs. Near IJondon.

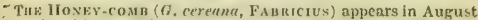
ahout bee-lives. Wings one inch one fourth to one-third of an inch, grey, with a common, depressen, brown back, the tip notched and brown; head ashy-grey, with the antenne threadshaped; the corselet asliy-grey, with an oblong, brown spot on the back. Near London.

\section{ILYTHIA (LATREILLE).}

Tize Green Shaben ( $I$, folonellit, Stremevg) appears in June in gardens. Wings one inch one-third, greyish green, with two wavy, toothed, paler streaks, having a black twin point between.

\section{MELIA (CvRtis).}

TIIR PAle SHourder (11. sorir, Cunris) appears the middle of July; the wings anteriorly pale, posteriorly ashy-grcy, witlt an indistinct dusky waved streak.

TurdVanscot Tontury (af. bipunctunu, CunTrs). Wings with two whitish points and black streak. Kare. Near I ondon.

Curtis's limane (M. flemmen, Curtis), Rare, Near Lonton.

Diku’s Sutky (M3 sericeq, Stbri Ens). Near London.

EUDOREA (CURTIS.

The Patz Grex (Ĺtu, pallida, Curtis).

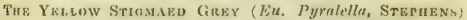
"appears in spring about nettles. Wings threc-fourths of an inch ; fir st pair asliy at the base, with a brown streak before the midile, from which arise, on the miter edine, two small yellowwh spots, bordered sliehtly with black ; in the place of a posterior stigrma, a somewhat kidney-shaped yellow spot, very slightly eliged with black; behind this stigma, a waved brown hand near tha hincler margin between two white waved streaks. Near Coombe Wood,"

THE TuRe Streaknd (Eu, tristrigella, Stephens). Near London.

The Hoary Grey ( $h u$, dubitalis, Strpunens). "Wings ten liues to ten lines and a half; first pair hoary or ashy, with a cross-waved, black streak before the middle, which externally sends off two blackish spots, the tirst of which is joined to the alyer edge ; then in the place of the posterior stigma, a distinct 
decp black Greek chi $(\chi)$ prostrate in the expanded wings; behind this a posterior, irrefrular, almost interrupted brown band between two waved whitish streaks; fringes ashy grey." Near London.

Tar Largr Grey (Eu, cembrella, STEPHéNs) "appears upon pine trees. Wings one inch; first pair gshy, with a paler, straight, indistinct streak bofore the middle, fund darker on its outer elge; a second posterior whitish, rather curved on the outer and brown on the inner edec; in the place of the hinder stigma, au indistinct brown (ircek chi, $(X)$ opposite a brown spot the upyer edge; sccond pair dull whitish. Common." Near Loudon.

TuE DRAB Grey (Fu. subusra, Sternens). "Fommi in woods. Wircs five-sixths of an inch to one inch, pale brown, with two indistinct paler streaks; second pair faint brownish." Near Jondon.

TuE Mutanine (Eu. muramu, Curtss).

The Line Gruy (Eu. lineola, Curtis). Near London.

Tü Restn GREv (Eu, Resiner, (STHphens). "Wings two. thirds of an inch, ashy, waved across with black, with silvery ashy bands,"

Tut Suaul, Gnev (Fu. Mermolln, Strpirka) "frequent: hedges. Wings two-thinds of an inch, somewhat ashy grey, with two remote brown streaks; a blackish spot scarcely con. spicuous in the middle of the wing; a black cyclet with a white pupil, or black mark, resembling 8 , at the outer margin of the wing towards the posteriors. Variable." Common. Near London.

Tue Narrow Grity (Eu. angustea, Curtis). Nicax London.

\section{PHYCITA (Cuntis).}

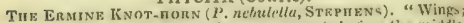
first pair whitish, with two or thee cross spots before the micldle, nud two other spots in the place of the linder stimm in Nortuide; behind these an obscure, rather broken, blackish strcak, and behind this, near the tip itself, a black spot on the upper edge; and frequently on the hinder margin a row of very minute indistinct brown dots; sccond pair whitish, shining, with white silky friuges, Very uncommon," Near Lomklon.

The Pownikro KNos-nore ( $\boldsymbol{P}$. dilutu, Haworti). "Wings three-fourths of an inch; first pair rather narrow and long, red. dish ash, amd very much asiny-frey towards the upper edge, with a narrow band red just before the middle, and white towards the thinner margin, and a second towarts the linder margin broader, waved on the outer edge, including a whits waved streak; in the place of the hibder stigma twyo conspicuons cross deep black spots, ast in the hinder margin, which is hoary white, a streak of deep black dots; secont pair brown. Very uncommon." Near London. 


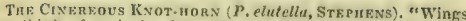
two.thirds of an incli; first pair pale brownish, or ashy-grey, with a straight fainter streak, darker on the edge, before the middle, and an oblique whitish one towards the hinder margin; second pair whitish. Rather rare." Near London.

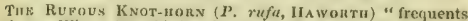
hedpes. Wings two-thirets of an inch; first puir narrow and entirely rufous, with two very indistinct streaks. Very similar to the preceling. Uneommon," Nenr London.

THE SMAL ERMine KNot-unR ( $\boldsymbol{P}$, angustella, Steruens). "Wings two-thirds of an inch; first lair narrow, whitish, with two yery slender, brown, cvanescent streaks before the middle, with a black spot in place of the anterior stigma, and four others, close together, disposed in form of a square, in place of the hinder stigma, behind these a decp black, and very wavy streak, and often a marginal row of black dots; second pair white, spotless. Very rare." Near London.

TIE RED-strkARED KNOT-IORN ( $l$. semi-rufa, StrpIENS). "Wintes two-thirds of an incla; first pair narrow, achy-grey, with two darker and very indistinet streaks, and a red stripe at the thinner nartain. Very uncommon." Near London.

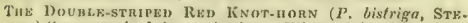
pusvs) " appears in July, on buslics. Wings cight lines and a half; first pair narrow, longish, rec, with a ncarly straight white streak before the middle, and another oblique, rather waved, near the hinder margin; and then on the margin itself a third, composed of minute brown dots: second pair brown. Near London, and Norfolk,"

TuE Tivin-harian KNot-horn ( $P$. gemina, Starfens). "Wings seven tines and a balf; first yair narrow, rufous, with a central, somewhat oblique, two-fold brown band, the hinder markin lroadly tinged with brownish-red; second pair faint browu. Exceclingly uncommon." Near London.

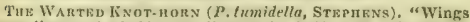
sever line's and a half to ten lines and a half; first pair reddish at the base, nearly in the middle at straight three-coloured band, which is nnteriorly white, then black, then broad red (and in the male ?) clevated, as if resembling a wart; behind this thrcecoloured band, two very black spots in place of the linder stigma; the hinder margin deeper reddish, hehind a brown, wavy, indistinct streale; then, in place of the hinder stigma, two cross brown clots: second pair deep brown." Near London.

THE Assocrate (P. consocielln, (iRrana). Near London.

TILE BROAD-BARRED KNOT-HOAN ( $P$. fuscin, STEPIKNS). "Wings three fourths of an inch; first pair ashy, with a very broad hand in the middle, occupying half the wing, reddishbrown-ash, and bordered on cach side with brown, in which is a pale space as far ns the upper edge, and in the place of the liuder stigrma, one or two cross, contiguous, black dots, Very uncommon," Near Loudon. 
tue Stranghr Knotmonn ( $P$. advenella, Grrmar). Near Londion.

THF MA EULED KNOT-HORN (J', marmorea, STErHENs). "Wings three-fourths of an inch; first pair ashy-gley, with a very strateht streak almost in the midalle, red, posteriorly white, nearly reaching the upper edge, aud hordered on the outer edife by a black band, which band is waved on the outer edge, and forked towards the upper clige; this lami is also tcrminated by a white waved streak, and anotlict narrow waved red hand near the hin. cler margin; tringes deep lead-colour, and very shining; in the place of the hinder stiptna a cross, curyed, or obscure, snohe. black creseent; second pair brownish, with darker fringev. Very rare." Near London.

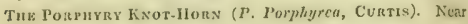
London.

Tuk Dovk colouren KNot-Horn ( $P$. Rhenelli, GEMAR). "Wines nine lines one-fourtlı; first patix glaucous ash, with a band before the middle, smoke-hlack, broncler at the nuper edge, and including a white bloteh at the thinner margia; hirder mar. gin dullish-red, with a pale waved indistinct streak; in the place of the hinder stigma in Nortua, two criss brown dots; sceond pair whitish, with the hinder margin itself brown." Ncar hondon.

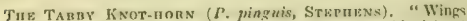
ten lines and a tralf; first par pale grey, with a deep-black band almost on the base, and a second much narrower, contiguour, and a third wavy and streak-shaped towards the hinder margin, and a fourti belind the third: sccond pair white, shinimg, woth the hinder margin slizhtly daker; fringes silky white. Very uncommon." Near London.

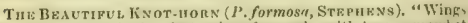
five-sixths of an inch; first pair rufous-ash, with two somewhat double streaks, and fur interjacent character, resemblims the letter 1, black; sceond pair brown. Very rare." Near Lonton.

Tuz Blunt-winged KNot-uore ( $P$. obtusa, Stephans). "Wings right lines and a lialf; first pair obtuse, brownish-red, with a brown band on the base, bordered on the outer edge by some imperfect rufous streaks; second pair brownish. Very rare." Near London.

TuE SpECKLED KNOT-Horn ( $P$. ornatelln, GrRMAn), "Wings ten lines and $n$ half; first pair pale brownish, clouded with white and black, with a white posterior streak, and another composed of black and white dots on the margin; sceond pair brownist. Very rare." Near London.

'un Pine Knot-nonv ( $\boldsymbol{P}$. Abiefella, Geraratt). Near London.

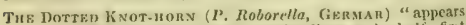
in June (l). Wings twelve lines to twelve lines and a hali; first 
pair varied, red and ashy. grey, with two brown wayy streaks, and three or four black dots close tugether, in place of the hiuder stipma, Uncommon." Near London.

Tuk Perpisu Kмот-иorn ( $\boldsymbol{T}$, cristelle, Germar), "Wings one inch, rufous purple, somewhat sjotted with grey, witl two brownish streaks, edged with whitish; sccond pair as in the foregoing, Very rare," Near London.

The Plane KNothorn ( $P$. legutelli, Glanar). " Wings twelve lines and a half; first pair ashy-grey, with grey and brown, a darker streak in the middle, and a wary one between it and the linder margin; between the streaks and in the place of the hinder stigma, dots, or blotehes, often occur." Near Lon. don.

THE Brown KNot-nore ( $P$. fuscr, StEPIENS). "Wings ten lines and a half, pitch-brown, with two streaks and a spot brown. Similar to the preceding in every respect except colour; but distinct." Near London.

Th: Mnat KNot Honn ( $P$, palumbellu, Genman) "appears in June. Wings one inch; first pair asley-grey, with two wary black streahs, bordered broaully on the outer edge with rosy, second pair whitislt, with the margin darker. Uncommon," Near London.

\section{ONOCERA (STEPUENS),}

TuE Turath Enane (O. Cardui, Sieruens) "appears in May and middle of August, about thistles. Wings one inch onesixth to one fourth of an inch, pure white, with mumcrous deep black sjots; ell the fringes pure white, very shining, and almost silvery; secoud pair pure white, smoke-coloured, largely on the upper edge, and more or less on the hinder margin." Near London.

TuE Hosy Vunker (O. carnella, Sternens) "apperts in May. Winges one inch, first pair yellow, with the sides blood-red. Uncommon." Near London.

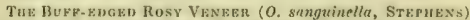
"found with the preceding. Wings one inch one-twelth; first pair blood-red, with the upper edge pale, and a broed yellow :tripe on the thiuner margin rather darker," Near Loodon.

The Ren Lead ( $O$ miniosmlla, Stepuens).

TuE Latine (O. Lotella i StepueNs).

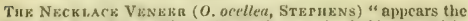
begmaing of spriag. Wings eleven lines and a half, brownisli, with a double yellowish streak in the midlle, and a sccond short and necklace-ilike at the posterior angle; second pair brown, with the wing ribs darker, abd fringes black, Very rare." Near London.

The Mouse Brown Veneer (O. ahenella, Eteriens.) 
"Wings ten and a half lines, spotless; first pair monsc-lrown; second pair dingy; the pulpi declined and curved. Very rare," Near London.

CRAMBUS (FABRTCIUS),

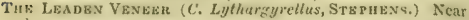
London.

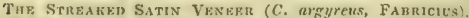
"Wings one inch, suotless, silken; first pair sulphur-silvery in certain positions, with the wing ribs posteriorly brown. Very. uncommon. Norfolk." Near London.

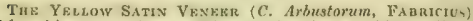
" found in grassy places. Wings twelve lines to thirtcen lines, spotless, silky; first pair sulphur-ycllow; second pair brown. Uncommon." "Near London.

Tuk WIITE SuTry VENFER (C. argentellus, STEPTENG) "found among prass. Wings one inch, spotless, silky; first vair silvery; second pair whitish. Perhaps a mere varicty of the last." Uncommon. Near London. don.

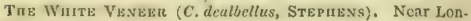

The Pfart-strah Vhierr (C, hamelles, Stapinss). "Wings eleven-tweliths of an inch; first pair greyish, tile-red, with a pure white, broad streak drawn from the base to the end, and inwardly with one indentation in the middle; near tlie hill. der margin a reetangular brownish streak; behind this the wings are ash-eolouret, but in the middle of the hinder matrin four cleep black cross spots; second pair brownish, with thic frinees pare white and shinning. Very rare. Norfolk." Near Londoll.

Tre Pontlavo Venent (C. Lentochlellus, Curtis), "Wings retuse, dull brick-red, with pure wbite simple and ramifying streaks; second pair brownish-ash, spotless, with snow-white fringes, Very rare." Near London.

Trua Infan Vinger (C. paseuclles, Steruzss) "appears in dugust in meadows. Winss five-sixths of an inch; first pair in the middle yellowish; with a broad white silvery line, spear. shaped, througl the length of the wing : an oblons pateh at the tip; two oblique white lines before the tip; second pair whitish; all brown underneath." Near London.

Tue Copse Vhneer (C, Dumetellus, Stephens), Near London.

Tue He八tu Venezil (C. ericellus, Stephen3). Near London.

THE Dark Inlatu Veneer ( $C$. pratellus, Stephins) "appears the middle of June and beginning of $\Lambda$ ugust, in meatows. iVings five-sixths of an inch; first pair whitish, with a silvery line lengthwise in the middle, shooting off on the binder part simple branches like streaks," Near London. 
Tne Nanrow Veneen (C. angustellus, Stephens), Near London.

Tuz Gisukn Venkne ( $C$. hortuellus, StEpmens), "Wings eleven-twelfths of an inch; first pair ashy-grey, with the streaks and wing ribs paler, and the fringes of a briliant golden hue; towards the hinder margin a kneed, somewhat silvery streak; second yair brown, with pale silky fringes. Common." Near London.

The Straw Yellow Veneen (C. cespitellus, Strenexs). "Wings eleven-twelfths of an inch; first pair struw-yellow, witi two kneed brown streaks; fringes of a brilliant golu-colour; second pair pale brownish, or whitish, with the fringes aslyygolden, Norfolk," Near London.

The Mountain Venefr (C. montanellus, Steriens).

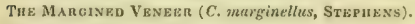

The Drvey Venuen (C. tristis, Steprens). "Wings eleven. twelitlis of an inch, spotless; first pair reddish brown, and conly in certain positions posteriorly streaked; sccond pair bruwn. Very rare; Norfolk." Near London.

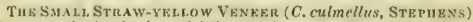
"appears the leginniug of Judy and August. Wings nine lines and a half; tirst pair yellowish, spotless, with a smple marginal silvery streak; sceond pair ashy-brown, with a silvery marginal streak. Common. Norfolk."

THe Dark Dwarz Vhxier (C. auriferellus, Stephens), "Wimgs balf an inch; first pair nitch-black, shining, in some positions goldeu-putch, with two evanescent, darker, very wavy streaks, conspicuous only in a certain light; with threc decp black spots on the hincler margin near the posterior angle; second pair and fringes brown. Very rare. Kent."

Thz Pyany Yenker (C. pygmaus, Steriens).

The Rayen Venegr (C. vadiellus, (Curts).

The PEarl Venter (C. margaritellus, Fabrerus).

The Brono-strear Venenr (C. tatistrius, Curtis). "Wings one inch; first pair brown, with a broad and pertect silvery streak in the midale; jalpi projecting forwards. Very rare." Near London.

Tuf Peanl Venkir (C. Pinctellus, Stepnens) "appears in June and August. Wings eleven-twelfths of an inch; first pair Jellow, with a silvery longtudinal patch, broken into two; the first of which is oblong; the posterior narrow at the basc, nlmost rhomboidal, with a dark brick-red margin; sccond pair whitish, underacath all brownish. Uncommon." Coombe ivuod.

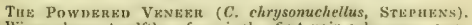
"Wings cleven-twelfths of an inch; first pair asliy-grey, very" thickly sprinkled with brown dots, with two brown streaks; 
fringes gold-coloured and shining; second pair brown or nshy, with the fringes silky white." Near London.

THE Dew Vheneg (C, rorelles, Stepuens). Near Yondon.

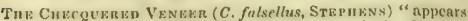
in August, in meadows. Wings three-fourths of an inch; first pair with short indistinct brown rend white streaks ; second pair any. frey, spotless; head and corselet anlly-frey, abdomen brown and shining. Uncommon," Near Londion.

THK Barmen Vrager (C. latecllus, Sthpuens) "appears the middle of June, in meadows. Wings five-sixths of all inch to cleven-twelfths of an inch, whitish, with various longitutinal brown lines, and two brown streaks. Common," Near London.

The Eanow-struped Veneer ( $C$. inqrinatellus, Steplevs; " appears in meadows. Wingrs ten lines to ten lines and a half, first pair asliy-grey, or pale brownish, with two unangulate or kneed streaks, brown, edged with whitish, the first in the mudills, the second towards the hinder margin; the frimges pale goluter, shining; sccond pair brownish-white, with whitish silky 1ringes. Cambridge,"

TuY Arij) Veneer ( $C$. aridellus, Cuntis), Near I,ondon.

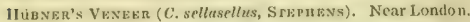

Tик De*кY VeNser C. fuscelinellus, Stupunss). Near London.

TuE Juent Vuxier (C. olblusellus, Stephisu). Near Lonton.

THE COMMON VENhen (C.pptrificellus, STERHExs) "appears in August in meatows. Wings one inch one-twelfth; first pair brownish-ash, with the upper edige brownish, and a pure white streak in the midelle branched posteriorly; second pair very large, brownish, spotless," Near London.

The Br.ack Strate Veneer (C. nigristriclles, StepheNo). Near London.

The Eaglet Veneer (C, aquilellus, Stepuens).

TUE Yellow Venfer (C. palmellus, STepHeNs) "appears in meadows. Wings one inch onc-twelfth; first pair pale yellow, with a short wlite strcak in tlie middle, bordered by two brown lines; second pair brown, spotless. Perliaps a varicty of the Common Venect (C. petrificellus)." Near London.

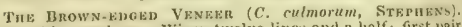
" Found in mealows. Wings twelve lines and a half; first pair avby brown, with a brown upper edge and a slender pure white streak in thic middle, slightly forked on the linder part; sccond pair brown. Common." Niar London.

CHILO (ZINCK. SOMMER).

TIE AQUatic VENEER (C. forfirellus, GiraAar and Z. S. 123) " appears in July, in marshy grounds; first pair red straw-jel. 
low, somewhat clouded with brown, with an oblique brown line at the tip hehind a black spot; all the wings have frequently a treak of brown dots on the hinder margin ; second pair whitish; anterna reddish," Near Lozdon.

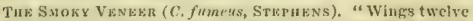
lines and a lialf; first pair obtuse, smoky, straw-yellow, with the upper edge darker; second pair white, with a strong smoke. coloured strcak near the hinder nuargin, composed of snall con. fluent dots. Very uncommon."

The Dot Benrer (C. puneligerellus, Stephens).

Tuk Wanseor Venexn (C, Phrugmitellus, Gyanan). "Wings onc inch one-sixtlı; first pair aljrupt, ratlier rlomberial, duil straw-yellow, with numerous darker streaks; on the himder margin a common row of minute black dots; second pair ample, whitish, Very rare,"

Tun Giganic Vanter (C. giganfellus). "Frequents marblics, frest pair of wings yellowislt-ash, spotiess; second pair white; palpi projecting forward, head asd corselet yellowish, abdomen ashy-grey. Very rare." Near London.

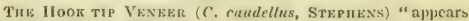
the end of June. Wings one inch one-fourth, somewhat tailed, brick-red, with a brown line towards the hinder nargin. Encommon." Near London.

\section{PLUTELLA (SchRANE).}

The Naritow-wiveni) Veskir ( $I^{2}$. Acinaridella, Stepin.s.s). "Win"s one inch onc-sixth ; first pair very narrow, longish, duli straw-ycllow, with a streak from the base to the midllle, which in sounc positions appears dakker; sccond pair whitish, shininfe, with the fringes yery thick, Jong, shir:ing, somewhat straw-yellow. Very uncomaon." Near London.

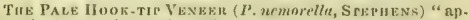
fears in August, in woods. Wings ten inches one-lualf ; first pair looked, straw-ycllow, with a dusky strcak from the base to the middie, and a brown spot in the midile rather within the streak; secoad pair whitish, with the tips rather brownish. Uncomnon." Near London.

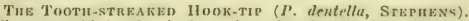
Wings two-thirds of an inch to three-fourths of an inch, brown, hooked at the tip, with a common white fillet on the back, with one indentation; lieal and corselet snow-wlute, with rustbrown sides. C'aterpillar sluining, green, with a purple line on the back. l'upa ycllow ; inliabits a spindle-shaped cast, which is open at both ends. Near London.

THE Waix\&cot Hook-тij) ( $P^{\prime}$. scabrella, StrenEN4). Wings nine lines and a half; first pair hooked, black, towards the upper edge longitudinally half-pale streaked with indistinct 
brown, black towards tlec thinner margin, with imperfect indistinct pale streaks; sccond pair pale brownish. Very rare. Near London.

THE HeDok BuL ( $P$, sulfuleatella, Sterniss).

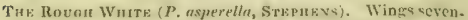
tweliths of an incls, hooked, white, with an obscure band, and a large thee-conered brown puteh in the thinner margin. Very scarce.

\section{YPSOLOPHUS (FABRICIUS).}

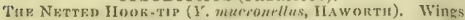
eight lines to eight lines and a half; first pair retuse, yellowish, with numerous darker nettings, and the tip sharp-pointed: sceond pair pale brownish; antenna ringed with white, Un. common. Coombe Wood, and near London.

The Dnuma Barned (Y. Persicellus, IIAivorti) appears in Scptenber, in woody places. Wings cight lines and a half; first pair bright golden-red, shining with two oblique brewn bands in the middle. Near London.

Túk White Sunvmeren (Y. rostellus, Ihworth) aplears the beginning of September, about naks, Wings seven lines and a half to eight lines; first pair shining, golden-red at the hase, with a large, oblong, whites sot on the upper edge, in which are some hrowin dots, a white blotch nt the posterjor angle; second pair ashy-grey, spotless.

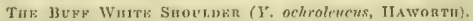
Wings two-thirels of an inch: first pair pale buff coloured, with an oblong whit ish patch at the base, under the upper edge. Very uncommon. Near London.

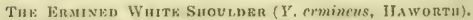
Wines two-thirds of an inch; first pair white, with numcrous small dots towards the upper edge, and another larger townds the hinder margin black, a yellow fillet or stroak from the bave behind the middle, terminating in small lorownish clouds towards the upper edge. Very uncommon. Near Jondon.

Tu: Strkaквр Whte Shoutakn ( Wings two-thirds of an inch: first pair whitish, with varions ashy-red streaks, and fringes burnt-horown, but yellow towards the posterior angle. Uncommon. Near London.

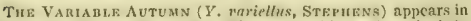
September, in woody places. Wings two-thirds of an inch to three-fourths; first pair more or less red or brown, often spotted, and witl a black line from the base of the inner margin. Near London.

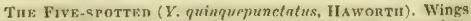
eight lines and a half; furst pair golden redulish, with a very deep 
black short line at the base of the inner margio, and brown spots on the disc. Uncommon. Near London.

TUE Dotren Dran (Y. lutosus, IA worTi) frequents wondy places. Wings eight lines to eight lines and a half; first pair palish or dull brownish-white, or pale-y cllow, dotted with brown, fud various dots seattered over the erlge, fringes yellow, Near London.

THE YeLlow-yrunged Wnitr ( $Y$. flariciliefus, H人wortu) frequents woody places. Wings three.fourths of an inch; first pair white, or whitish, with yellow postcrior sjeets on the upher edge, and yellow fringes. Near London.

ThE Rusty Mitak ( $\boldsymbol{Y}$. rufimitrellus, Stephens). Neas London.

The Broad Strask (Y. fissellus, Stepurns). Wings twothirds of nn inch, white, with a very straikht broak black streak from the base to the end; colour of the wings variable. Very uncommon. Near London.

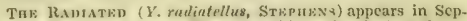
tember, in woody places. Wingx two-thirds of an inch to three. fourths; first pair golden red, redelinh, or brownish, with varions streaks. Very variable. Near London.

THE Moor ( 1 , mutellus, Stephens). Near London.

THF BLACK BAгK ( $\boldsymbol{r}$. Viltellus, HAWоптI) appeats in summer, on elm trees. Wines seven-twelfths of an inch to swothirds; first pair ashy-grey, with a common black longitudinal line on both sides, repanted; the hinder marpin with minute black dots, a blackish hollow line at the tip of the wing. Near London.

Tuz Suas.s, Ruxic (Y. sequellus, II wvonтu) appears in August, on heiges. Wings eight lines and $\mathrm{B}$ half; first pair snow white; a common deep-black longitudinat fillet, forked at the base, variously waved at the sides; spots on the sides, black, somewhat cross-wise, and of various form; antenna hlark, ringech with white; shanks of the first pair of legs brown; head, cor. selet, abdomen, aud thighs white. Very uscommon, lient.

The GRry Streak ( $\boldsymbol{Y}$. Mesperidellus, Strphens). In gardens. Wintes seven-twelftus of an ineh; first pair pale, with a terminal axlyy-black band, the upper edge with posterior black dots; second pair yale brownish. Very unconmon. Near London.

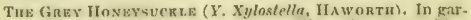
tens. Winges half an inch to seven-twelfths, ashy-grey, with a common white streak on the back, indented on both sides.

EUPLOCAMUS, (LATREILE).

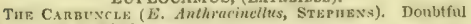
as a native of Britain.

The Tassez (E. tessellus, Sternens). Doubtful as lritish. 
Tut Mintan (E. mediellus, Stirinsa). Near London.

TINEA (IIAWORTH).

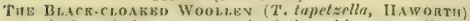
appear's in June, in houses; occurs in clothes, skins, or woullens; very abundant in the hides of animals, or feathers of birds, Wings eiglit lines to nine lines and a half; first pair black, but white from the middle to the tip, the whiteness soiled with indisfinct brown spots; second pair ashy.grey; body and limbs black; antenne bristle-sliaped; head white. But too common every where.

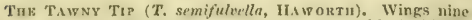
lines and a half; Arst pair pale, or tawny-grey, with the hinde: border breally, and the frimes deeply, tawny; second pair brownish lead coloured, shining; fringes of uniform colour. Norfolk, and near London.

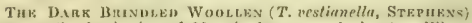
a)pears the beginning of May in houses and closets. Wines seven lines to nime lines and a half, kreyish-black, with thick rlarker clouds, and a paler spot in the maddle; head hairy, tawny. Common. Near London?

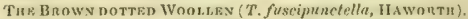
Found with the last. Wings half an inch to seven-twelftis, nsliy-grey, with about four black scattered spots on the dise. Near 1 ondon.

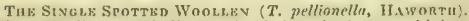
Wings five lines to six lines and a half, ashy-brown, shining, with a brown spot behind the midtile. Near London.

Tur Many Spottso Yerbow (T. migripunctella, HAwontu), Wing five lines to five lines and a half; first pair tawny, much spotted with black, the spots gencrally forming bands; head bairy, tawny. Very uncommon. Near Lontion.

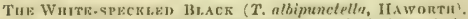
Wings five lincs and a half ; first pair almost black, irregularly clouted with minute white dots and lines; second pair black, shining, with large blackisl fringes. Very uncommon. Neak London.

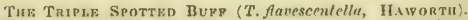
Wings seven-twelfths of an inch; first pair very pate yellow, with three indistinct brown dots; second pair whitish, with a tinge of yellow; head hairy, tawny; palpi pale-yellowish. Very rare.

TIV TRIPLE-spotTen Yelhow (T. Lappelli, Haworti) frequents noist grassy places. Wings haif an inch to sevenfivelfths; first pair yellowish, with two cross contimuous deepblack dots beforc, and one behind the middle; second pair yale hrown; head hniry; palpi black, ycllow at the tip. Very uncommon. Near London. 
TuE Sulpuun ( $T$. su/phurellu, II. wart appears in November, about onks, Wings the liues to five limes and a half; tirst pair narrow, somewlat hooked, solphur-yellow, rather syrinkled with brown, Very uncommon. Near Lundon.

Tuk Destroyer ( $T$. Destructor, StromeNs). The first pair of wiogs of a yellow-brick colour, without spots; the secnnil pair of an ashy-grey-briek colonr; all the fringes of a yellowhrick eolour; the forcheal tawny. Common, and very destrue. tive in Museums of Natural llistory.

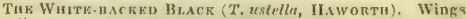
five lines and a half; tirst pair decp-black, shining, with a large yellowish spot in the middle, with a broad common yellowishwhite band or fillet from the base to the end; the edre of the upjer edge with srome yellowish dots; sceond pair black, in certain positions with a tiuge of purple. Near London.

THE Motrten Wool.ten ( $T$. cloucella, HAwontu) appears the midkle of March. Wings five-twelfths of an inch; first pair greyish-brown, with two brown spots on the upper edge; second pair black. Near London.

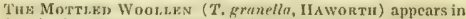
July? in houses and hedpes. Wings five lines and a half to seven lines; first pair livid, with deep-black and white spots; second pair lead.coloured, Freally fringed on the thinner mar. fin; eyes black; heact white. Near London.

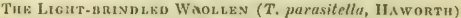
Wings seven limes and a half to eight lines and a half, cinereous, powdered with white, dotted, and somewhat cheruered with pitch-colour. Uncommon. Near London.

\section{LEPIDOCERA (STRPIRNS).}

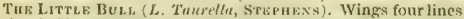
and a half; first pair brownish-ash, with the binder margin paler; second pair pale hrownish, with the margin and trioges in sone positions darker; head and palpi very hajry. Very rare. Near London.

Tue Berstuz (L+setelln, Stepuess). Near London.

The Munue-peatuezen ( $L$. mediopectinella, Stapuevs) appears in fietds. Wings five lines; first pair dull-yellowish, clouried with brown; second pair pale-brown; antenne black, strongly peetinated in the midclle with thickish remote rays; jalpi large, and thickly clothed with hair. Uneommon. Ncar London.

THe Miles ( $L$. Chenopodiellit, StrineNs).

\section{INCURVARIA (HAWORTH).}

TuF Fratekrpo Dsamond B.uk (I. musculellu, Stenuens) appears the beginning of May, on hedges, Wings half an inch 
to seven-twelfths; first pair pitch black, shining, with two coul. cal, three-cornered, snow-white spots on the thinner margin; the first before, and the second, smaller, behiud the middle; second pair broyn ; anteune of the male thickly pectinated, black, with remote hairs. Near London.

Tue Feathered Twin-srot ( 1 . pectinella, Haworti) ap. pears the beginning of May. Wings half an inch; first pair of a yellowish-brown, with a whitish, indistinct, somewhat twin spot before the middle of the thinner margin, and another single towards the hinder margin; antenne of the male as in the last. Far more rare than the foregoing. Near London.

OzHr.Man's Twin Srot (I. Oellmannielta, STupHeNa), Wings half an inch to seven-tweltths; first pair purplish-black, with two common three-cornered pure-white or silvery spots, one before, the other behind the midille, a snow-white spot on the upper edge, near the tip, and almost opposite the second spot on the thinner margin; second pair black, shining, with all the fringes black. Uncommon. Near London.

THE SNOW WhIte Spot (I. spuria, IIAwortu). Wings seventwelfths of an inch; first pair paler, of a less purple hue than the preceding; two marginal snow. white spots, and a rery minute opposite snow white dot on the upper edge, and more renote from the tip than in the last, in otlier respects similiu. Very rare. Near London.

Тне TRввһ about oaks. Wings six lines to six lines and a half, very brown, with three white spots disposed in form of a triangle, rather behind the middle of the first pair, two spots on the upper edge, and a third, somewhat opposite on the thinner margia. Uncommon. Near London.

The TWo-spotted BrowN (- oppositelln, IIAWoRth) appears in June on hedges. Wings five and a half lines to six lines, smootl, incumbent, obscure brown, with two equal yellow spots, one at the thinuer margin, the other opposite on the thicker margin; second pair brown, spotless, hcad and corselet of onc colour. Not common. Near London.

The Dovale-spotten Brown (- 4- munctella, Ilawortii). Wings half an inch; first pair brown, with two approximating white spots in the middle, another at the thinner margin larger, across. More scarce then the last. Ncar London.

THE Dounle Golv-spottra (-, minutella, Haworth). Wings four and a half lines; first pair brown, with two yellow marginal spots; one in the middle of the thinner margin, the other behind the middle, and nearly reaching the upper edge. Very uncommon. Norfolk.

THE Two Spotey Black (-, arelli, IIAworth). Wings five lines, nll narrow, deep black; the first pair with two some. what opposite marginal spots; the first is placed rather behind 
the middle of the upper edge; the other in the middle of the thimner margin; head brown; hinder lcgs black, somewhat spiny, with whitish geniculations. Very rare.

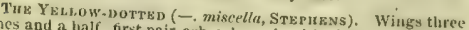
lines and a half, first pair ash-coloured, with about four minute yellow sprots in the middle, one of them is on the upper cdec, another on the thimner margin, a third near the upper edge, a rare. Near London.

KNock's ( - Knockella, HAworth) appears in spring. Wings one-third of an inch; first pair golden brown, with a posterior spot on the upper edge, and a common broad streak from the

base to the posterior angle, whitish or very pale yellowish white.
Very rare. Near London.

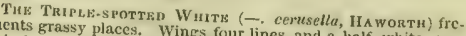
quents grassy places. Wings four lines and a half, white, poslarly disposed; second pair thee indistinct brown sjots trianguish fringes. from the beod specimens the first pair have a brown line the thinnerse to the middle, and a black spot near the base of Uneommon. Near London.

The Golv Stripky Sable (-formosella, Stwentes). Near

Ar.нIN's (-. Altinella, IHAwortu) appears in June (?) on hedges. Wings four lines and a half ; first pair brown, with a siogle oblique cross gold-coloured line, arched backwards, Un-
common. Near Chelsea.

MEGLRL'S (-. Afegerlellit, StePIENS).

\section{LAMPRONIA (STEPHENS).}

TIE Trupte-spotTen HLACK (L. capitella, StepHens) appears the beginning of May. Wing 3 six lines and a half to seven lines and a half; first pair deep black, three yellowish white spots in each, the first with the third or opposite one at the inner marrin, into a narrow band, the second at the outer margin, the hizder margin yellowish. Uncommon. Near London.

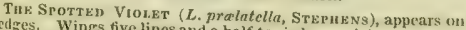
hedges. Wings five lines and a half to six lines, violet or purple, rather shining, with a medial streak, and two opposite spots tuwards the upper edge, white; head rust brown. Uncommon.
Near London.

TIR Fovi-mpotted BLACK ( $L$. rupella, Staphexs) appear, the beginning of June. Wings six lines and a half to seven lines; first pair golden-brown, with four large fold-coloured spots, two at the outer, and two at the inner margin. In Haworth's specimens, the first pair of wings are more of a black than golden brown colour, and the spots white rather than of a golden hue, Uncommon, Kent. 
Tha Four Srotrso Buown (L. Aavimuctella, Stronnes). Wings five lines to five lises and a half; first pair purpliall-pitch colour, with an obhique interrusted ychlowish band before the midale, and two marginal, obliquely opposite, yellowish spots behidu the middle; sceond pair deep black. Uncommon. Near London.

The Manarn Dorted (L, margine-penctella, Strpness). Near London.

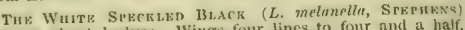
appears about hodges. Wings four lines to four and a half, first pair diep-black, with two margiual opmosite spots hefore, and two others ralber behind the mithle, white, or snowy, or golden, and three or four minute white dots on the hinder margin, fringes ashy-grey, or at the edge, deep black, with a row of white spots; second pair decp-black; head deep black. V'ery rare. Near Chelsea.

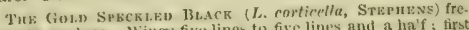
quento garlens. Wings five lines to fire lines and a ha'f ; first pait (lecel) black, with abont three gold-coloured spots in the middle of the upper edge, remote, equidistant, and two other Fold. colourcal somewhat opposite spots at the thinner marfin, nume. rons very minute spots senttered over the dise; scend jair (lecp) black; head hairy, rust-brown. Uncommon. Near Chelsea.

TuE Buack Under Wina (L. atrella, Stermexs). Near London.

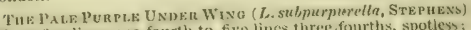
Wine five lines one-fourth to five lincs three fourthe, spotless; first pair gold-coloured; second pair purplish-brown. Coombe Wood.

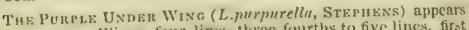
in Fehruary. Winte four lisu's three-fourths to five lines, first pair brisht purple, with minute seattored whi:ish spots posteri. urly, and a common whitish band.like spot towards the posterior ancle, second jair brown, with the tip, in certain situations, purplish brown-golden. Very rare. Niar London.

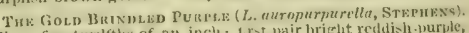
Wings five-twolftis of an inch; hrst pair bright redhish purple, thickly sprinkled with polden dots and spots; second pair brown, with the edpe towards the tip, in some positions, of a pur. plish folders tint. Very similar to the preceding. Very rare. Kent.

Thr RFD Goun (L. Fhro-aterlu, Strruess). Wing four tine, three-fourths ; first pair jed or purplish-fulden, a posterior

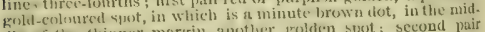
ale of the thimer markin tuother golden syot; sccoud pair purplish-golum, vaiable. Very rare. Neta Lumdon.

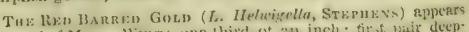

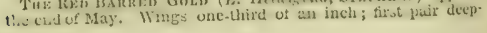


Fuld coloured, with four equidistant purplish-red bands, the firt at the base, the second shighty arched belore the middle, the thirit bethiud and forked at the tipper edse, the fuurth at the hinder border, united to the third near the thinner marein, fringes boww; second pair colyer-brown, especially behind the middle. Very uncommon, Kent.

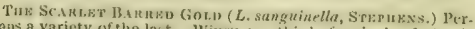
hajs a variety of the last. Wims one-third of an ineh; first pair pure yellow, or of a brizht golten hue, with four blood-redbands, the first ami second disposed as in the preceding, the third forked at the thiuncr marnin, aud entire at the upper edge ; fourth at the hinder border, distinct from the third; fringes gold coloured or brown; second pair withont the purple hue; hizder wings stronger, and much paler than in the last. Near London.

Sipr's fion (L. Seppelle, HAworru? Wings three lines one fourth; first pair golden, shining, witis two straight silvery streaks; sceond pair suming with golden; boly micute, biack; antenna short. liare. Near London.

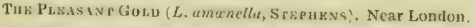

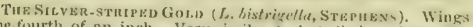
one-fourth of an inch. Very similar ts but dintinct from, the last. The tirst pair of wings not so grolcen, with the silvery streaks rather arched, the last behind the middle; second pait brown or dull lead-colvured, shining, wisthout the golden hait Very rare, Near London.

THe Drup Gosu (- auroguttella, StembNs). Near London.

GRACILLARIA (IA WORTH).

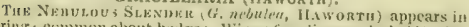
sprita ; common about hedges. Wings four lines and a lablf to five lines; rist pair asliy-krey, with larke black clouds, blark bands on the upper edge, and interrupted whitislistreaks. Near Londen.

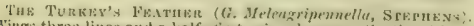
Wines three lines and a half; first pair ashy-grey, the tip with an eyclike deep black tot. Very uncommon. Near london.

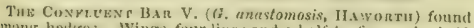
anoug hedec.3. Wings four lines and a half to tive and a half, pule, with fuur or five strong reduish bands. Variable. Coombe
Wood.

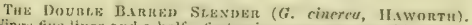
Wings five lines and a half; first pair very narrow, with two or three narrow, oblique, cquidistant brown bands, the lat rather behme the middle, more indistinct and slightly interrupted, Jeasins a round brown spot near the thinter matgin; second pair biuwn, or pitch-brown. Uneommon. Coumbe Waod.

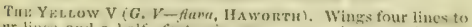
f.ar fincs and a lialf; first pair very narrow, bruwn, with the 
letter V-like mark yellow, and when the wings are expanded prostrate, and an incurved yellow band towards the hinder mar. fin; second pair tawny-brown; head yellow; corselet brilliant gold-coloured; hinder shanks very hairy. Very rare. Near l.ondon.

The Changeabe (G.versicolor, Hawortu). Wings one-thírd of an inch; furst pair linear, in some situations variable, with the edge tawny, golden, copper, and green, hinder shanks vers hairy. Perliaps a mere varicty of the preceding. Near London.

Тнх Onscuns:-struet ( $\boldsymbol{G}$. substrigu, In worti). Wings four lines and a half; first pair brownish-red, with about four some. what angular, indistinct, equidistant, whitish streaks, black on the inner edpe; second pair lead-brown, shining. Uncommon. Coombe Wood.

Tü SEMi-WHite BAR (G. semifascin, HAwortu). Wings five lines and a half, ashy-purple, with a slight anterior white pale bar on the upper edre, obligue inwardly, and white spots on the upper edge. Uncommon. Near hondon.

The Triangle-sharked Purple ( $G$. yurptrer, Hawortis). Wings seven-twelfths of an inch, all bright; first pair purple, with a three cornered central half band on the upjer edge, pos. teriorly white, and half another; second pair dull brown. Very uncommon. Near London.

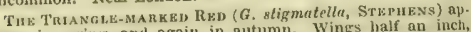
pears iu suring, and again in autumn. Wings half an inch, ashy-red, or reddish, with a three-corncred white half band on the upper edige, posteriorly notched. Near Chelsea.

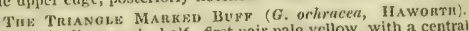
Wings six lincs and a half; first pair pale yellow, with a central three-cornered whitish band, posteriorly notched. Very rase. Near London.

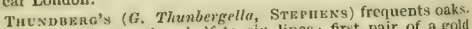
Wings five lines and a half to six lines; first pair of a gold colour, shining, with a purple blotch at the base, and a large purple spot towards the tip; second pair golden, spotless; body small, jellow, with the back of the abdomen black; antenua short, black. Not very uncommon. Near Londos.

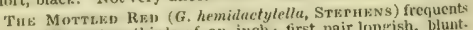
oaks. Wongs two-thirds of an inch; tirst pair longish, bluntred, with a large, oblique, darker band at the base, with a central spot, the tip, and numerous dots chestnut red on the upper teige; second pair lcad-coloured. Coombe Woot.

THe RUFors SLENDER (G, rufipennella, STEPHitss). Near Loudon.

Tна Prank Rwu (G. elongella, StrpukNs). Wings seven lines nnd a half ; first pair red, with two indistinct brownish dots in the midele, placed one behind the other; antemna whitish. Very similar to $G$. hemidactylella, of which it is, perhaps, a nere valuty, or difference of sex, but smaller. 
Tue Violdceoug Senvidir ( $G$. miolacea, HAworti). Wings five lines and a half; first pair purple-violet, clouded with deepblack purple. Closely resembling the last, but smaller, and strongly clouded. Very uncommon. Near London.

Tne Livid Si.ender (G. roscipennellu, StepHris. appears in woods. Wings half an inch; first pair pale livid, with an indistinct purplish tinge, two oblique cross dots before, and two likewise cross behind the middle, the edge with various scattered brown dots, the rim of the upper edge also thickly dotteal with brown; second pair as in the preceding; antenna brown. Near London.

THe White Slenden ( $G$. leucapennella, Stejrens).

The Poptan Shanden (G. praangusta, IIAwortu) appenrs in May, frtequents poplars, and occurs in pardens. Wings six lines and a half; first pair ashy-grey or ashy-hrown, with the upper edge paler at the base, in the middle of the wing deep black lines, then indistinct, and disposed in an interrupted streak; second pair brown, with very long fringes, Common.

\section{ALUCITIDA (LEACH).}

\section{PTEROPHORUS (GEORFROY).}

Tite Laroe Wute Plouk (P't. pentaductylus, Fabricius) "appears the middle of June, on banks, where nettles abound. Wings one inch one-twelfth, open, eleft, divided into five spaces, snow-white, with the fifth digit distinct. Abundant." Near London.

Marsualn's Plume (Pt. spiloductylus, Srkphens). Very rare.

TuE Gnev Woon Pluak (Pt. bipunctidactylus, Haworti). "Frequents woods. Wings cleven-twelfths of an inch; first pair forked, asliy frey, with an incisure one line and a half long, the segments parallel, above a pair of black dots, distinct from the tip of the wing, the intervals of one line and two thirds, and another smaller dot in the same place, remote from the base and other dots; second pair forked, rust-brown, shining; abdomen of one colour, with the second wings having two silvery lines on the back, two on the sides, but not reaching as far as the midkle, and two below these again; a black line on the sides near the abdomen. Very uncommon."

THi BRown Woon Plum (l't, fuscoductyius, Curts). "Oecurs in woods. Wingy five-sixths of an inch to cleventwelfths, brown, spotless; fhrst pair narrow at the base, forked as far as the third part; secund pair three-forked, with the third digit separate; abdomen longish, slender, ratlier thick in the middle; legs white, nearly silvery ; antenna halt the length of the body. In Ilaworth's specimens the first wings are brickbrown, with an indistinct darker spot at the incisture. Common." Near London. 


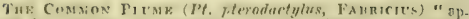
pears in octoler, fund frequents pardens, shrubs, and wondy. Wins: one incls cleven twelfths ; first pair forked, licary, or red; scennd pair divided into three, brown. Variable." Near Lendon.

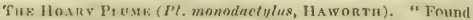
om hanks. Wing- bite lines and a half; first pair lociay, retune, with an indistinct fissure; second pair divided into thec, brown. Very rare." "Near London.

Curtas's Plume (Pt. tephraductylus, Cuntis). Near Iondon,

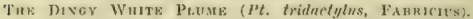
"Wings nine lines and a half, cleft; first pair forked, fund pure wlite; stcond pair threc-forked, brown. Very utucommon." Near London.

TuE SNow.whтt Plumk (I't. miveiductylus, SrepukNs). Near Londion.

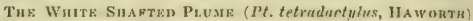
"frund on banks. Whngs nine lines and a lialf; first pair eleit. palc, with white lines; legs white. Very uncommon," Near I.ondon.

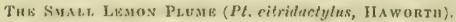

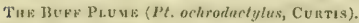

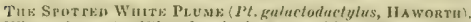
"Wings eleven-twelths of an inch, snow-white; first pair cleft, spotteil with brown. On hedges. Very uncommon." Near London.

Tин: Lenon Premk ( $P t$. leurodactylus, Cunte), "Wings nine lines and a half; first pair forked, pale sulphur-yellow; sc. cond pair divided into three, brown; fringes brown, Very rave." Near Iondon.

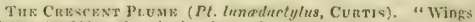
elesen-twelfth of an inch; first pair forked, dull brown, jmmaculate, with f ycllowish-white creacent-shayed, or slightly arched band near the fissure; second pair divided into threc, brows. Uncommon." Kent, and Darenth Wood.

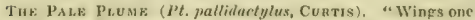
inch; first pair forked, pale-jellow, with clouds of a darker bite; second pair divided into three, jale yellow-brown." Near lon. iton.

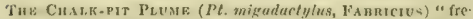
quents chalky dintricts. Winers one inch; first pair forked, whitish, spotted with brown : sccond pair divided into three, brown; legs white, spotted with brown ; body white. Very unconmon." Near London.

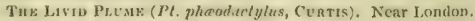

The Trianere Plesas (Pt, trizanodactylus, Curris) "ap)pears the end of Aurust, about bushes, in chalky places. Wings hive-sistlis of an inch; first pair forked, jale, with a tinge of 
bufi-colour, and a posterior three-cornered brown spot on the upper edge; second pir divided into three, pitch-brown." Near London.

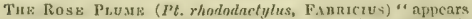
in kardens, alout roses. Wings five-sixths of an inch; first pair cleft, yellow, darker at the base, with two white streaks; secounl pair divjed into thee, with two anterior yellowish lobes, a third white, with a large rust-brown spot before the tip; berly rustbrown, with the sides of the corselet yellowish." Near Lowdon.

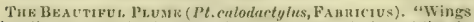
nine lines and $\mathrm{n}$ half; first pair ashy-brown, darker at th.e tij) with a large yellow sjot, inner margin indented, hinder margin cleft; second pair three-forked, black; legs ringed with white. Occurs about bushes, but very uncommon," Near London.

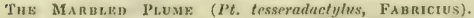
"Wings nine lines and a half; first pair forked, clouded with ashy-grey ; second pair clouked with brown. Very rare." Near London.

Tur Bntinlod Pluak (Pt. punetituctylus, Cuntis). "Wings nine lines and a balf; first pair forked, ashy-grecn, cloucled with whitish, with numerous dots on the upper edge, an indistinct posterior streak, white; second pair diviled into threc, deep black. Very rare." Near London.

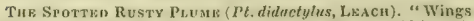
eight lines and a half, open; first pair rust brown, half-forked, shary, some white streaks or jatches, hinder margin white under the tip; second pair three-forked, spotted with white; legs ringed with white, Very uncommon." Norfolk.

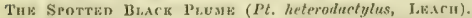
"Wings cight lines and a half, open, cleft, black, with white spots; first pair forked; second pair three-forked. Ver'y uncommon." Near London.

The Sarat. Pruve (P't, microdnetylus, Curtis). "Winge six lines to six lines and a haif, brown, open, with a streak and spots white; first pair forked; scond pair divided into three. Very rare," kent.

\section{ALUCITA (SCOPOLI).}

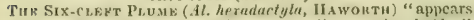
carly in spring, in houses. Wings seven lines and a htulf, all open, generally divided into six parts, with numcrous rays divided at the base; the fringes as if colierent, and waved with a white and ashy-colour. A very elegant and remarkable surecies." C'uterpillar feeds on the honcysuckle. "Common." Near London.

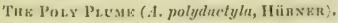

Hiworta's Puume (.t. pecitiduetyla, Stepukss). 



\section{N D E X.}

1

bbot's F. 7

Haxas, 124

Grossulariala, ib. pantaria, ib.

I'mata, ib. hastoLA, 92

Asclepiadis, ib.

illustris, 93

Iriplasia, 92

Urliog? ib.

(tнати, 74

piniperda, ib.

CIERONTIA, 24

Atropos, ib.

trias 74

froeor, ib.

(1) $11.14,14$

arersuta, 142

Mislactata, ib.

fuliginata, ib.

funata, ib.

inomata, 141

lectatu, 142

Marginepunclata, 141

osseata, ib.

remutata, 142

stobsericeala, 141

tirgularia, ib.

rowtis, 95 aprica, 96

Caloris, ib. luctuosa, 95 nigrirena, 96

Solaris, ib. Acosmetia, 97

arcuosa, 98 caliginosa, ib. lineola, ib. lutescens, 97 rufula, 98

Acnonycta, 78 Alni, ib.

auricoma, ib. cuspis, ib. Euphorbia, 80 Euphrasia, ib. ligustri, 78 megacephala, ib. Menyanthedis, 80 Psi, 79

Rumicis, 80 similis, ib. strigosa, 79 tridens, $b$.

ADELA, 195 cuprella, ib. De Geerella, ib. fasciella, ib. Frischella, ib. Latreillella, is. 
Panzerella, 196

Reaumerella, 195

Subzella, ib.

Swummerdammella, ib.

Robertella, 196 víridella, 195

Admirable, see Aliterman B, 9 Admiral, (P'et. Mus.) - see Alderman $\mathbf{B}, 10$

EGerra, 27

Asiliformis, ib.

Chrysidiformis, 28

Culiciformis, ib.

Cynipiformis, $i b$.

Ephemeraformis, 29

Formiciformis, ib.

Ichneumoniformis, 28

Mutillaformis, ib.

Spheciformis, 27

Stomo.vyformis, 28

Tipuliformis, ib.

AGERIID $A, 27$

Afternoon, 158

Afzelian, 175

Agate, 123

Aolath, 36

Tau, ib.

Aczossi, 147

capreolatus, ib.

dimidiatus, $i b$.

pinguinalis, ib.

Agrotena, 148

costalis, ib.

Acrotis, 50

a qua, 5]

annexa, $i b$.

aquilina, 52

corticea, 50

cinerea, 53

cuneigera, 52

dubia, 53

Exclamationis, ib.

fumosa, ib.

Hortorum, ib. lineolata, 52

lunigera, 50

nebulosa, 53

nigricans, ib.

obeliscala, ib.

ocellina, 52

pupillata, ib.

radia, 51

radiola, ib.

ruris, 53

sagillifera, 52

Segetum, 51

subgothica, 53

suffusa, 51

Tritici, 52

valligera, 51

venosa, 52

Albinella, 225

Albin's If ampstead Fye, see

Hampstead B, 10

Albin's, 225

Azcrs, 110

consobrinaria, 112

consortaria, 111

conversaria, ib.

destrigaria, ib.

fimbriaria, 112

muraria, 111

piperitaria, ib.

repandaria, 110

rhomboidaria, 111

roboraria, ib.

sericearia, ib.

Alchemist, 99

Alcon 13,18

Alder, 79, 105

Alder Leaf, 202

Alderman 13, 10

Alexis $\mathbf{3}, 18$

Alpine White B, 5

Almstraener's Straw, 188

dzuctra, 231

hexadactyla, ib. pacilodactyla, ib. 
polydactyla, $i b$.

KLUCITID $A, 229$

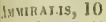
Alalanta, ib.

IUPHIP $\mathrm{RA}, 63$

pytamidea, ib.

hurms 158

Gerningiana, $i b$.

Walkeri, ib.

AsNaCAMPSIS, 188

affinis, 190

albimaculea, 192

aleell $a, i b$.

alternella, ib.

angustella, $i b$.

aspern, 190

atra, 191

Bctulea, 189

cinerella, ib.

contigua, 1.90

decorella, 191

diffinis, 190

dodecella, $i b$.

domestica, ib.

fulvescens, 192

fuscescens, ib.

guttifera, 191

IIübneri, 190

interruptella, 192

Juniperella, 188

lacteclla, 190

Listerella, 189

longicornis, ib.

Inctuella, 19]

lutarea, 18.9

maculella, 191

marmorea, ib.

Mouffettella, 190

nebulea, 189

nigra, 190

nivella, 191

Populella, 189

proxima, 191

quadripuncla, 192 rhombella, 189

rusticella, ib.

sarcitella, 190

sequax, 191

subcinerea, 189

subrosea, 191

Tremella, ib.

tricolorella, ib.

ANAItIs, 124

plagiata, ib.

Ananta, 95

cordigera, ib.

Ifeliaca, ib.

Afyrlilli, ib.

Anclioret, 31

A NchyLorin $\mathrm{A}, 166$

biarouana, 167

diminutana, 166

fractifasciana, $i b$.

funalana, ib.

Lundana, ib.

obtusana, ib.

retusan $a, i b$.

siculana, ib.

subuncana, ib.

uneana, 167

unculana, 166

ANGERONA, 107

Prunaria, ib.

Angle-barted Single Dot, 165

Angle Shades M, 89

Angle-stripe AI, or Angle-striped

Sallow, 84

Angle-striped Sincle Dot, 165

Angled Carpet, 119

Angled Oak, 106

Angled Thorn, 106

INIA, 144

emarginata, ib.

limbata, ib.

Axisoptary, 102

Escularia, ib.

leucophearia, $i b$.

A nomalous $\mathrm{M}, 98$ 
Ant-hawk, 29

Anturocena, 22

Filipendula, 23

II ippocrepidis, $i b$.

Loti, 22

Meliloti, ib.

Peucedani, 23

Scabiose, ib.

Trifolii, 22

Anticrea, 122

Berberata, ib.

derivata, 123

rubidata, 122

sinuata, ib.

Antique Muslin, 45

ANтітнеsia, 159

Betuletana, 160

corticana, 159

yentianceana, 160 marginana, ib.

oblongana, ib.

Pruniana, ib.

pullana, ib.

Salicella, $i \dot{b}$.

tripunctana, ib.

Antler, 50

ApaseA, 71

didyma, 72

fibrosa, 71

I-niger, 72

nictitans, 71

oculea, 72

ophiogramma, ib.

rave, ib.

secalina, ib.

unanimis, ib.

Apatura, 11

Iris, $\hat{\imath} b$.

APATELA, 78

Aceris, ib.

Bradyporina, ib.

J,eporina, it.

A PHeLIA, 169

egenana, ib. egestana, $i b$.

expallidana, 170

plagana, ib.

pauperana, 169

A plocera, 136

casiata, $i b$.

favicinctala, ib.

April, 75

April F. See Silver Spot F, 7

A pril Fritillary. See Silver Spot $\mathrm{F}, 7$

April F, with few spots. See Prince F, 7

Aquatic Veneer, 218

Arched, 169

Arched Wainscot, 87

Archer's Dart, 51

Arctia, 42

aulica, 43

Caja, 42

IIebe, 43

matronula, 42

purpurea, 43

villica, 42

ARCTIID AE, 39

erella, 224

Argent and Sable (Harr.) See Spear Beauty, 125

Argentine, 209

Argus Blue B, See Arion B, 18

ARGYNNIS, 7

Adippe, 8

Aglaia, ib.

Charlotta, ib.

Lathonia, 7

Niobe, ib.

I'aphia, 8

A noynolepia, 182

cneana, $i b$.

Barmanniana, 183

Bentleyana, 182

decimana, 183

yemmana, 182

Lathoniane, ib. 
INDEX.

lesserana, $i b$.

Turionana, ib. ARGY ROMIOES, "200

Alnifoliella, 202 Blancardella, 200

Corylifoliella, 202 Cramerella, ib. cuculipenell $a$, ib. Cydoniella, 201

Harrisella, ib. hortella, 202

Klemanella, 201

Mespilella, ib.

Myllerella, ib. obscurella, 202 Rayella, 201 rufipunctella, 202 Schreberella, 201 sylvella, 202 trifasciella, 201 tristrigella, ib. Argrrostria, 200 aurifasciella, ib. aurivittella, ib. Godartella, ib. I. V-ella, $i b$. I. I-ella, ib. literella, ib. semifasciella, ib. Aнey noтоzA, 181

Bergmanniana, $i b$. Conwayana, 182 Daldorfiana, ib. Hoffinanseggiana, ib. permixtana, ib. subaurantiana, ib. Arid Veneer, 218 Arion 13,18 Aran Brown B, 13 Arrow, 52 Asellus, 45 ish-coloured, 177 Ash-grey, 189 Ash Tree, 99
Asoria, 148 flamealis, ib. Aspen $\mathbf{F}, 7$ Aspilates, 116 citraria, $i b$. gilvaria, ib. purpuraria, ib. respersaria, ib. Associate, 213 Augur, 54 August Oak, 105 Aurelian's Plague. See Goosefoot, 117 auritella, 210 Aurotine, 209 Autumn Border, 130 Autumn Carpet, 126 Autumn Green Carpet. See Autumn Carpet, 126 Autumnal Dagger, 196 Autumnal Rustic, 50 Awned, 194

Azure Blue B, 17

\section{I3}

Handed Brown, 12, 13

Banded Iron, 174

Batsa, 136

bimaculata, ib. punctata, ib.

Barberry Carpet, 122

Barred Arches, 66

Barred Blotch-back, 159

Barred Chestnut, 55

Barred I)warf, 183

Barred Míarble, 183

Barred Minor, 73

Barred Nettle, 171

Barred 1ied, 108

Baned Rustic, 50

Barred Sallow, 85

Barred Straw, 123 
Harred Yellow, 119

Barred Umbre, 113

Barred Veneer, 218

Barred White, 200

Bath White B (Lew.) See Rocket B., 4

Baumannian, 183

Bay-shouldered Button, 176

Beautiful brindled Brown, 191

Beautiful Carpet (IIaw.) See Clifden Carpet, 125.

Beautiful China Mark, 150

Beautiful Crescent, 168

Beautiful Grey, 172

Beautiful Kook Tip, 144

Beautiful Knot-horn, 214

Beautiful Marble, 167, 191

Beautiful P'lume, 231

Beautiful I'ug, 132

Beautiful Snout, 145

Beautiful Switt, 29

Beautiful Underwing, 95

Bedford Blue B, 17

Bedstraw Carpet, 119

Bee Fly Hawk, 27

Bee Hawk, ib.

Beech, 33

Belle (Harr.) See Lead Belle,

116

Bentleyan, 182

Bergmannian, 181

Bilberry, 62

Birch, 149

Hirch Long-cloak, 160

Birch Morha, 114

Bird's Wing, 63

Bishop, 80

Bistox, 104

Betularius, ib.

hirlarius, ib.

Prodromarius, ib.

13lack Annulet, 129

Black Arches, 40

Black Back, 221
Hlack-border, 162

Black-bordered Blue. See Kent

Blue 13,18

Black C, 56

Black Chestnut, 63

Black Cloaked, 161

Black-cloaked Woollen, 22 ?

Black Clouded, 192

Black Crescent F, 6

Black Double-blotched, 173

Black-dotted White, 19I

Black-edged Marble, 162

Black Feather, 208

Black Fringe, 204

Black Hair Streak B, 15

Black-headed Pygmy, 205

Black Heath, 101

Black Kidney, 96

Black Lackey, 48

Black Mountain, 101

Black Neck, 98

Black Quaker, 53

Black Rustic, 50

Black Silk Pug, 132

Black-speckled Grey, 189

Black Spot Brown. See Brown A rgus B, 19

Black Spotted, 55

Black-spotted Brimstone, 19:2

Black-spotted White, $i b$.

Black-sprigged Green, 179 Black-streak Veneer, 218 Black-stripe Edge, 163

Black Thorn, 31

Black Thorn Hair Streak B, 15

Black Tussack, 40

Black Under-wiog, 226

Black V, 41

Black Van, 113

Black Veined, 124

Lilack-veined White B (IIari.)

See Hawthorn B, 5

Blackamoor, 73

13lancard's, 209 
lood Vein, 115

lossom Tip, 97

10s5om Under-wing, 58

lotel-Lacked Grey, 165

Iotched Drab, 171

lorched Limerald. See Maid of Honour M, 110

the $B$ (IIarr.) See Alexis $B, 18$

he Argus B (Wilkes). See Alexis B, 18

fue Border, 125

thu-bordered Carpet (Haw.)

See Blue-border, ib.

lue-speckt B. See Azure Blue B, 17

lue Speckt B, with black tips. See Azure Blue B, ib.

Juat Angled Carpet. Ste

Angled Carpet, 119

Hunt's Flat Body, 187

Hhat Veneer, 218

Elunt-winged Blotch-black, 166

Hunt-winged Knot-horn, 214

Dosนมsa, 112

Abietaria, ib.

consonaria, ib.

crepuscularia, ib.

extersaria, 113

punctularia, ib.

strigularia, ib.

tetreyonaria, 112

Boberian, 165

Figh's Heanty. SceOsier, 83

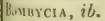

Viminalis, ib.

BOMB Y CID A, 36

Bordered Beauty, 115

Bordered Checquer, 144

bordered Fan-footed Wave, 140

Bordered Gireen, 155

Buidered Girey (Ifaw.). See Grey Heath, 102 Lordered Lime Speck, 135
Bordered Long-cloak, 160

Bordered Noveraber (IIaw.)

See Autumn Border, 130

Bordered Pearl, 152

Bordered Sallow, 95

Bordered Skipper 13, 21

Bordered Straw, 95, 210

Bordered White, 102

Boscan, 178

Borxs, 151

forficalis, ib.

Urticata, ib.

Bow, 32

BNADYะuETX, 115

amataria, ib.

Bramble M. See Dock MI, 80

Branched Holly, 175

Branched Streak, 176

Branderian, 157

Brass Pug, 132

Breeze Ilawk, 27

BREPHA, 100

notha, ib.

Parthenias, ib.

Puella, ib.

Brick, 59

Bride, 99

Bride Maid, 49

Bridge, 167

Bright Annulet, 129

Bright Oblique Dart, 159

13right-specked Gold, 201

Brimstone MI, 107

Brimstone Butterfly. See Primrose $\mathrm{B}, \mathrm{I}$

Brindle M (Wilkes.) See Winter Beauty, 103

Brindle-barred Yellow ( Iaw. $_{\text {. }}$ ) See Yellow-brindled Bar, 131

Brindled Beauty, 104

Brindled Brown, 190, 191

Brindled Ermine, 199

Briadled Flat Body, 187 
Brindled Green, 77

Brindled Grey, 112

Brindled Marble, 183

Brindled Plume, 231

Brindled Pug, 133

Briudled Straw, 188

Brindled Streak, 113

Brindled White Spot, ib.

Bristle, 223

33ristle-horn M, 86

Brixton Beauty, 96

Broad Bar, 32

Broad-barred, 177

Broad-barr'd Knot-horn, 213

Broad-bar, or Broad-barred White, 77

Broad Bordered Under-wing, 49

Broad Chiverned. See Chevron, 123

Broad Streak, 221

Broad-streaked Drab, 170

Broad-streak Veneer, 217

Broken Bar, 166

Broken Barred Carpet, 120

Broom, 69

Broom But-tip (Harr.) See Broom-tip, 130

Broom Egger, 37

Broom Ilip, 130

Bronze Bar, 97

Brown Annulet, 129

Brown Argus B, 19

Brown Argus 13. See Speckled

Wood 13, 12

Brown Blotch-back, 161

Brown-bordered, 162

Brown Brassy, 207

Brown Brighi Eye, 60

Brown Brindled, 187

Brown Button, 175

Brown Cloaked, 161

Brown Copper, 207

Brown-dotted Woollen, 222

Hrown-edged Veneer, 218
Brown Enfeld Eye, See Speakled

Wood B, 12

Brown Feather, 208

Brown Gold, 193

Brown Green, 207

Brown-grey Pug, 134

Brown Ilair Streak B, 14

Brown Heath, 101

Brown Knot-horn, 215

Brown Marbled Carpet, Sec Deep Carpet, 121

Brown Meadow Eye. See Mea. dow Brown B, 13

Brown Muslin, 44

Brown Pinioned Brocade, 67

Brown Rustic, 50

Browa Scollop, 127

Brown Silver Lines, 127

13rown Spot Pinion, 58

Brown Streak, 192

Brown Tail, 42

Brown Tunbridge Grayling. See

Grayling B, 12

Brown-veined, 186

Brown Wall B, 12

Brown Wood Plume, 229

Brunette, 55

Brush-foot, 98

Brussels Lace, 110

BRYOPHILA, 80

glandifera, ib.

perla, 81

Buck-bean, 80

Buff Arches, 81

Buff Argus, 115

Buff Argus (Don.) See Blood

Vein, 115

Buff-blotched, 208

Buff-edged, 176

Buff-edged Rosy Veneer, 215

Buff Feather, 208

Buff Lackey, 47

Buff Notch Wing, 180

Buff Plume, 230 
IN DEX .

Buff Pug, 133

Buff Straw, 193

Buft Tip, 30

Buff-white Shoulder, 220

Bulrush, 86

Bupalus, 102

Piniarius, ib.

Burnished Brass or Burnished M, 94

Buraished Brass Likeness. See scarce Burnished Brass, 94 Butterfly Fimerald, 108 Buttoned Snout, 145 Byringerian, 177

C

3bbage B, 3

abbage MI, 70

abbage Bright Line, 69

IABEMA, 113

exanthemata, 114

pusaria, 113

rotundaria, 114

ALLIMORYHA, 46

Jacobace, ib.

rosea, $i b$.

I.осAM РА 65

exoleta, ib.

vetusta, ib.

ILOPIIASIA, 91

Linarice, ib.

aloric, 96

ILOTFNIA, 93

viridis, ib.

ILYPTRA, 82

Libatrix, ib.

Imberwell Beauty B. See Wil. low B, 9

3MP $\bar{~} \mathrm{~B}, 108$

Margaritata, ib.

ampion, 68
Cамptogramsa, 128

Lilineata, $i b$.

Canary, 105

Canary-shouldered Thorn. See Alder, 105

Capilaria, 196 pubicornis, ib. Tesserella, $i b$.

Caradina, 60 Alsines, 61

ambigua, 60

cubicularis, 62

glareosa, $i b$.

implexa, $6 \mathrm{I}$

lavis, ib.

Morpheus, $i b$.

redacta, $i b$.

Sepit, $i b$.

sordida, ib. superstes, 62

Carpet M. See Cloaked Carpet, 120

Carbuncle, 221

Carmelite, 34

Carpocarsa, 169

arcuana, ib.

Carrot IIawk, 26

Catephia, 99

leucomelas, ib.

trifasciata, ib

Catocala, 99

conjuncta, 10

elocata, 99

Fraxini, ib.

Nupta, ib.

Pacta, ib.

promissa, 100

sponsa, 99

Cexiena, 73

IIibernica, 74

Lancea, 73

leucographa, 8 .

renigera, ib. 
Celara, 124 imbutata, is.

Central Silver Bar, 205

Centre-stripe, 152

Centre-bar MI, or Centre-barred Sallow, 85

Centre killet, 176

Cerioo, 49 lenta, ib.

Cетораси 4,82 diluta, ib. duplaris, ib. flavicornis, 83 flucluosa, 82 octogesima, ib. Or, ib. ridens, 83

Cenura, 31 arcuata, 32 bicuspis, 31 bifida, 32 erminea, 33 furcula, 32 fuscinula, ib. integra, ib. latifascia, ib. Vinula, ib.

Cerusella, 225

Chalk Carpet, (IIaw.) 125

Chalk Carpet, 117

Chalk-hill Blue 13, 18

Chalk-pit Plume, 230

Chamomile Shark, 91

Changeable, 228

Ciraonia, 35 Dodonea, ib. quernea, ib. lloboris, ib.

Cinrfas, 50 Athiops, ib. Cespilis, ib. confinis, ib. fusca, ib. Graminis, il.
Chartcrea, 92 Delphinit, ib.

Crunissa, 128 dilucidaria, 129 obscuraria, 128 operaria, 129 pullata, ib. serotinaria, ib. Chequered Grey, 177 Chequered Notch-wing, 180 Chequered I'ebble, ib. Chequered Skipper 13, 20 Chequered Straw, 154 Chequered Veneer, 218 Сiекматови, 131 rupicapraria, ib. vulgaris, $i b$.

Chimatophila, 181 castaneana, ib.

Cimlaria, 193 rhomboidella, ib.

Cherry Leaf, 203

Cherry Leat Roller, 156

Cuestas, 129 obliquaria, 130 Spartiata, 129

Chestnut, 58

Chevalier, 71

Chevron, 123

Chevron (Don.) See Broomtip, 130

Cniso, 218 caudellus, 219 forficellus, 218 fumeus, 219 gigantellus, ib. Phragmitellus, ib. punctigerellus, $i b$.

Chimney-Sweeper, 136

Chip-axe, 116 Chicinora, 155 Fagana, ib. prasinana, ib.

Chlorissa, 109 
cloraria, ib. putataria, ib. thymiaria, ib. viridata, ib. Chocolate I'ip 31 Chosen, 99 Christernian, 186 Chrystaline, 176 CIDAREIA, 117 costovata, 119 didymata, 117 ferrugaria, 118 fiuctuaia, 119 implicaria, 118 latentaria, ib. miaria, $i b$. munitata, 117 olivaria, 118 propugnata, 119 quadrifasciaria, 118 Salicaria, ib. unidentaria, ib. iliated, 153 Cux, 145 compressa, $i b$. imbex Hawk, 27 inctella, 207 inderella, 128 incrella, 193 increous Lackey, 47 inereous Knot-horn, 213 inereous l'earl, 153 innabar Moth, 46 lay-coloured, 189 lay Fan-foot, 146 lay Pearl, 153 lay Triple Lines. See Triple. line Mocha, 115 LEDEOBIA, 146 albistrigalis, 147 angustalis, 146 bisirigalis, 147 coste-strigalis, ib. undulalts, $b$.
Cleft, 32

Cleogene, 136 niveata, ib. tinclaria, ib. Creora, 110 bajularia, ib. cinctaria, ib. Lichenaria, ib. pictaria, ib. leneraria, ib. viduaria, $i b$.

Clerck's, 203

Clifden Beauty, (Harr. Ev.) Ste Chalk Carpet, 125

Cliefden Beauty, (Wilhes D.) See Chalk Carpet, $i b$.

Clitden Blue B, 18

Clifden Beauty, 125

Clifden Carpet, (IIarr. V...M.) ib. Clicfden Carpet, (Wilkes.) Set Phoenix, 122

Clifden Nonpareil. See Ash Tree, 99

Cusiocampa, 38 castrensis, $i b$. Neustria, 39

Cloaked Carpet, 120

Cloaked Mirror, 73

Clostera, 31

anachoreta, $i b$. anastomosis, $i b$. curtula, ib. reclusa, ib.

Clouded August Thorn. See Angled Oak, 106

Clouded Border, 142

Clouded Brindle, 66

Clouded Brown, 196

Clouded Buff, 42

Clouded Carpet, (IIarr.) S.ee Phœnix, 122

Clouded Drab, 57

Clouded Golden B, 2

Clouded Iron, 159, 185 
Clouded Lead, 196

Clouded Magpie, 124

Cloud Moth, 53

Clouded Saffron B, 2

Clouded Silver, 136

Clouded Skipper B, 21

Clouded Straw, 181, 193

Clouded Sulphur B, 2

Clouded Yellow B, ib.

Clouded Yellow (IIaw.) See Clouded Saffron, ib.

Clouded Yellow. See Barred Yellow, 119

Cloudy Hog. See Clouded Skipper $\mathrm{B}, 21$

Cloudy White, 160

Comphasia, 170

assinana, $i b$.

aurifasciana, 171

bellana, 170

Cantiana, íb.

ictericana, ib.

interjectana, ib.

Logiana, ib.

longana, ib.

obsoletana, ib.

octomaculana, ib.

quadripunetane, ib.

rectifasciana, 171

Resinella, ib. sinuana, 170

CNethocampa, 38

pitiocampa, ib.

processionea, ib.

Coarse Wainscot, 187

Cocuyls, 184

grisean $a, i b$.

margaritana, $i b$.

marginana, ib.

roseana, $i b$.

rubroseana, ib.

Smenthmanniana, ib.

ruficiliana, ib.

Cock's Feather, 209
Cock's Head, 173

Codling, 168

Cognate, $20 \mathrm{~s}$

Colewort 1 , 4

Couras, 2

Chrysotheme, ib.

Edusa, ib.

Ettprome, ib.

Helice, ib.

Hyale, ib.

Paleno, ib.

Cozocasia, 40

Coryli, ib.

Combustan, 177

Comma, 87

Comma B, 8

Сомма, 8

C. $A l b u m$, ib.

Comma Carpet, 121

Common Blue. See Alexis $\mathrm{B}, 18$

Common Carpet. See Sable Carpet, 120

Common Emerald, 109

Common Ermine, 198

Common Fan-foot, $\mathbf{1 4 6}$

Common Flat Body, 187

Common Heath. See Brown Heath, 101

Common Long-cloak, 160

Common Marbled Carpet. Sec Hornsey Beauty, 121

Common Natch-wing, 180

Common Plume, 230

Common Pug, 134

Common Rough-wing, 178

Common V. Motb (IIaw.) See

L Moth, 113

Common Vereer, 218

Common Wainscot. See Pate

Wainscat, 88

Common Wave. See Twin Stripe

Wave, 114

Common White Wave. See

White Wave, 113 
Communana, 173

C'ompanion, 164 Confuent Bar V, 227

Connecting Umbre. See Urabre Link, 103

Consimilar, 176

Conwayian, 182

Copper 13, 16

Copper Japan, 196

Copper Underwing, 63

Copse Egger, 37

Copse Veneer, 216

Coracipennella, 208

Corn Rustic, 51

Coronet, 78

Cosuin, 84

affinis, ib.

diffinis, ib.

fulvago, ib.

Pyralina, ib.

trapetzina, ib.

Cossus, 30

ligniperda, ib.

Courtier, 43

Cow Parsnip, 186

Coxcomb, 34

Crambus, 216

Angustellus, 217

aquilellus, 218

Arbustorum, 216

argentellus, $\$ b$.

argyreus, ib.

aridellus, 218

Auriferellus, 217

cespitellus, ib.

chrysonuchellus, ib.

culmellus, ib. culmorum, 218

dealbellus, 216

Dumetellus, ib.

ericellus, ib.

falsellus, 218

fascelinellus, ib.

hamellus, 216 hortuellus, 217

inquinatellus, 218

latistrius, 217

luteellus, 218

Lythargyrellus, 216

margaritellus, 217

marginellus, $i b$. montanellus, ib.

nigristriellus, 218

obtusellus, ib.

paleellus, ib.

pascuellus, 216

petrificellus, 218

Pinetellus, 217

pratellus, 216

pygmaus, 217

radiellus, ib.

rorellus, 218

selasellus, ib.

tentaculelius, 216

tristis, 217

Cramer's, 202

Cream-coloured, 199, 210

Cream-pot 'Tiger, 42

Cream Pygmy, :05

Cream Short-cloak, 162

Cream-spotted Sable, 201

Cream Wave, $\$ 42$

Crescent, 71

Crescent Pinion, 84

Crescent Plume, 230

Crescent Rustic, 50

Crescent Striped, 64

Crescent Underwing, 48

Crested Buff, 178

Crimson and Gold, 149

Crimson-ringed B, 15

Crimson Underwing (Willes.)

See Promised, 100

Crocarlis, 105 elinguaria, ib.

Cross-barred Housewife. Siee Light Emerald, 108

Crossed Straw, 18.5 
Cross WVing, 103

Crow Feather, 208

Crow-foot, 77

Croydon Pug, 135

Cuckoo's Feather, 202

Cucullia, 89

Absinthii, 91

Artemisice, ib.

Asteris, 90

Chamomille, 91

fissina, $i b$.

Gnaphalii, ib.

lactuca, 90

lucifuga, 9 ।

Scrophularia, 89

Tanaceti, 90

Thapsiphaga, ib.

Umbralica, ib.

Yerbasci, $i b$.

Cud-weed, 9]

Cumberland Rivulet, 138

Cupid Blue B, 19

Currant Hawk, 28

Currant Leaf Roller, 156

Currant M. See Magpie, 124.

Curtis's Emerald, 109

Curtis's Ermine, 198

Curtis's Flame, 211

Curtis's Long Horn, 189

Curtis's Plume, 230

Curve Dotted, 187

Cygnipennella, 210

Cумпторнora, 84

Oo, ib.

cylindrella, 208

CуNтhia, 10

Cardui, ib.

Ilampstediensis, ib.

Levana, ib.
Dahl's Square Spot, 56

Daldorfian, 182

Dale's Silky, 211

Dark Annulet, 128

Dark Arches, 65

Dark-barred Grey, 172

Dark-barred Twin-spot. See Four-band Carpet, 118

Dark Irindled Woollen, 222

Dark Brocade, 67

Dark Brown, 189

Dark Checquer, 181

Dark Chestuut, 63

Dark Coronet, Var. See Coronet, 78

Dark Crimson Underwing. See The Bride, 99

Dark Dagger, 79.

Dark Dwarf Veneer, 217

Dark Forest, 127

Dark Gothic, 64

Dark Green F, 8

Dark Ileart M, 84

Dark Inlaid Veneer, 216

Dark Mlarbled Carpet. See Wild Carpet, 121

Dark Oblique Bar, 156

Dark Porcelain, 202

Dark Prominent, 33

Dark Rustic, 53

Dark Silver Stripe, 164

Dark Spectacle M, 92

Dark Spinach (IIaw.) See July Spinach, 123

Dark-streaked Button, 176

Dark Sword Giass, 51

Dark Sycamore. See Sycamore

I'ussock M, 78

Dark Treble.lines, 60

Dark Umber, 127

Dark Underwinged Copper. See

Swift Copper B, 17

Dark Underwing F, (IIaw.)

See Morning Crescent F, 6 
Jay Fly Hawk, 29

Disreera, 194

Oliviella, ib. sulphurella, 195

DAsycirira, 40 fascelina, ib. pudibunda, $i b$.

Daudridge's Middling Black F. See Scabious F, 6

Drab Day, 197

Drab Grey, 212

Death's-head Hawk, 24

December Moth, 38

Decimanium, 183

De Geer's Long Horn, 195

Deep Brown, ]71

Deep Carpet, 121

Deilephila, 25

aryentata, 26

Celerio, ib.

Daucus, ib.

Elpenor, ib.

Euphorbia, 25

Galii, ib.

Livornicn, $i b$.

Porcellus, 26

Denopeta, 46 pulchella, $i b$.

Delicate Pearl, 152

Delight, 116

Demi-dusky, 173

Demi-white, 210

bemure Wainscoat, 89

Depressakia, 186

albipunctella, 187

Alsirameriana, 188

apicella, 187

applanu, ib.

atomella, 188

badiella, 187

Bluntii, ib.

Carduella, 188

characterosa, 187

costos $a, 188$ curvipunctose, 187

gilvella, 188

IIeracleana, 186

immaculana, 188

irrorella, $i b$.

liturella, 187

nervasa, ib.

ocellana, 188

purpurea, ib.

putvidella, 186

Sparmanniana, 188

Umbellana, 186

venosa, 187

$Y$ atesana, 188

Desfontafnian, 176

Destroyer, 223

Devon Beauty, 112

Dew Lackey, 48

Devon Lobe, 131

Dew Veneer, 218

Dial, 179

Diamond-barred Pigmy, 205

Diamond Spot, 153

Diamiania, 151

lucernalis (?), $i b$.

Diapiota, 44 mendica, ib.

DictyopteRYX, 180

ciliana, 181

contaminana, 180

Forsklaeana, 181

Lafingiana, ib.

plumbana, ib. rhombana, ib.

D Irula 158

Athiopiana, 159

angustiorana, 158

Asseclana, 159

nebulana, ib.

porphyriana, ib.

rotundana, ib.

seriptana, ib.

semifasciana, ib.

sylvana, ib. 
Dingy, 69

Jingy Angled, 144

Dingy Brocade, 67

Dingy Dwarf, 183

Dingy Marbled, 160

Dingy Mocha, 114

Dingy Pearl, 152

Dingy Rosy, 184

Dingy Rustic, 61

Dingy Shell, 139

Dingy Skipper B, 20

Dingy Straw, 188-193

Dingy Straw-barred, 150

Dingy Streak, 194

Dingy Veneer, 217

Dingy Wave, 142

Dingy White, 43

Dingy White Plume, 230

1) (PHTHкRA, 81 ladifica, $\mathrm{i} b$. Orion, $i b$. runica, $i b$.

DiURNEA, 197 Fagella, ib. Novembris, ib.

Dirision Button, 176

Dock M, 80

Dodonean, 35

Dog's 'J'ooth, 70

Domestic, 190

Jonstis, 5 Apollo, $i b$. Mnemosyne, $i b$.

Dorsana, 162 Dorylas 13,18

Dot Bearer, 219

Dot Moth, 70

Dotted Border, 87

Dotted-bordered Wainscot. See Dotted Border, 87

Dotted Brown, 189

Dotted Chestnut, 62, 181

Dotted Drab, 170, 221

Dotted Grey, 190
Dotted Knot-horn, 214

Dotted Margin, 141

Dotted Rustic, 60

Double $\Lambda$ rch, 167

Double Barred, 98, 220

Double-barred Nettle Tap, 148

Double-barred Orange, 172

Double-barred Rivulet, 139

Double-barred Slender, 227

Double Bay Streak, 177

Double Crescent, 167

Double-gold Spotted, 224

Double Kidney. See Gold Tongue, 83

Double Line, 59

Double-orange Spot, 164

Double Scorched, 157

Double-silver Bar, 203

Double-spotted Brown, 224

Double-spotted Pinion. Sce

Twin-spot Pinion, 84

Double Striped, 147

Double-striped Pug, 132

Double-striped Red Knot-hozn, 213

Doubtful Dwarf, 183

Dove-coloured Knot-horn, 214

Drab Looper, 136

DREPANA, 144

falcataria, ib.

fasciata, 145

hamula, 144

uncula, 145

unquicula, $i b$.

Drinker Moth, 39

Dromedary, 33

Drone Bee-hawk, 27

Drop Gold, 227

Drury's Hawk, 25

Duke F, 5

Duke of Burgundy F, ( 11 arr.)

See Duke F, 5

Dunbar, 84 
INDEX.

Dun Lackey, 47

Durhain Argus, 19

Dusky Brindled, 154

Dusky Sallow M, 92

Dusky Thorn, 106

Dusky Veneer, 218

Dusted Black, 190

Dusty Drab, 169

Uusty Pearl, 153

Dwarf Cream Wave, 141

Dwarf Lutestring, 82

Dwarf Marble, 97

Dwarf Mlinor, 73

Dwarf Quaker, 58

Dwarf llod, 98

Dwatf Wainscot, 193

DYPTERYOIA, 63

Pinastri, ib.
Bagle, 52

Englet Vencer, 218

sling's Glory. See Ilawthoin, 75

iarly, 131

arly Cabbage B, 3

aly Grey, 68

arly Nettle Tap, 148

arly 'Thorn, 106

arly Toothed Stripesl (IItuw.)

See Tooth-striped, 131

atly Turnip B, 3

Jged Brown Argus. See I Hown

Àrgus B, 19

ight-dotted, 170

llow-striped Veneer, 218

Wer, 108

dLCtAA, 123

archatinata, ib.

comitata, ib.

Populata, ib. pyraliata, $i b$.

Spinachiala, it.

testatr, ib.

Elephant IIawk, 26

Eltoria, 108

fasciaria, ib.

Elm B, 9

emaryinella, 193

Eimbroidered Yellow, 101

Emerald Volute, 109

Eamplesia, 137

affinitata, ib.

albulata, 138

bifascinta, ib.

blandiata, ib.

candidata, 139

decolorata, 137

ericetata, ib.

heparata, 139

luteata, ib.

purpurata, 138

rivulata, 137

rusticata, 138

sylvata, 139

teniata, 138

trigonata, ib.

turbaria, 137

unifasciata, 138

Eimperor 13, 11

Emperor Mloth, 36

Enfield Fye. see Speckled Wood B, 12

Engaged, 99

Finicostoma, 194

Geoffroyella, ib.

Thunbergana, it.

ENNomos, 144

fexula, ib.

EnNycila, 148

anguinalis, 149

cingulata, ib.

fascialis 2 ib.

octomaculata, 148

Entire, 32 
Ėíyna, 114

albicincta, 115

ocellaria, ib. omicronaria, 114

orbicularia, ib. pendularia, ib. porata, ib. punctaria, 115 trilinearia, ib.

Epignaphia, 197 Avellanella, ib. Steinkelnerana, $i b$.

Esione, 115 advenaria, $i b$. apiciaria, $i b$. delectaria, 116 vespertaria, 115

Erisema, 31 coruleocephala, ib.

Erastrua, 96 albidilinea, 97 apicosa, $i b$. Bankiana, 96 fuscula, 97 minuta, ib. ostrina, $i b$. sulphurea, ib. uncana, 96 venustula, 97

Eremobia, 92 ochroleuca, $i b$. Entogaster, 38 Lanestris, ib. Ériopos, 81 $\boldsymbol{P}^{2}$ teridis, $i b$. Ermine Knot-horn, 212 Ermine 1'uss, 33

Ermined White Shoulder, 220

Erxlebella, 207

Essex Broad Border. See Bordered Beauty, 115

Essex Y, 94

Ethiopian, 159

Euclidia, 100 glyphica, ib. Mi, 101

triguetra, 100

Euchromis, 174

fulvipunctana, $i b$. purpurana, ib.

Eucosma, 128 undulata, ib.

EodoreA, 211 angustea, 212 cembrella, $i b$. dubitalis, 211 lineola, 212 Mercurella, ib. murana, ib. pallida, 211 Pyralella, ib. Mesinea, 212 subfusca, $i b$. tristrigella, 211

Eunnomis, 36 versicolora, $i b$.

Eulrpia, 46 cribrum, $i b$. grammica, ib.

Euprasia, 96 elegans, ib. Eupitriecia, 132 abbreviata, 133 Absinthiata, 134 albipunctata, 133 angustata, 135 centaureata, ib. cognata, ib. consignata, $\dot{i b .}$ elongate, 134 Exiguata, 133 innotata, 134 Lavigata, 133 Linariata, 132 nebulata, 133 nigrosericeata, 132 notata, 134 ochreata, 133 
piperitala, 135 plumbeolata, 134 pulchellata, 132 pusillata, 1:34 rectangulata, 132 rufifusciata, 133 sericeata, 132 simpliciata, 134 singulariata, 133 Strobilaia, 132 suberata, ib. subfasciata, 134 subfulvala, 135 subfuseata, 134 subumbrata, 133 succenturiata, 135 variegata, $i b$. V. atra, 132 venosata, 136 vulgala, 134 EUPLEXIA, 71 lucipara, ib. Loplocamus, 221 Anthracinellus, ib. mediellus, 222 tessellus, 221 LUPCECILIA, 183 allana, 184 angustana, 183 bilunana, ib. dubitana, ib. luteolan $a, i b$. maculosana, ib. nana, $i b$.

pygmaana, $i b$. Sodaliana, ib. URYMENE, 116 dalabraria, ib. ".tualta, 126 impluviala, ib. miata, ib. Psiltacala, ib. OTHEMON_A, 42 Itussula, ib.
Evtricha, 39

Pini, $i b$.

Eye-bright, 80

Eyed llawk, 23

Eyed Mocha Stone, 115

Eyelet, 52, 157, 199

\section{F}

Fabrician, 185

Fabricius's Nettle Tap, 148

Faint-dotted Brown, 192

Faint-silver Striped, 173

False Mocha. See Mocha Stone, 114

Fan-foot, 146

February Carpet, 136

Fern, 81, 126

Festoon, 45

Festoon Pigmy, 166

Feathered-diamond Back, 223

Feathered Gothic, 69

Feathered Lackey, 46

Feathered Thorn, 104

Feathered Twin-spot, 224

Few-spotted Ermine, 198

Fidonia, 101 atomaria, ib. carbonaria, ib. ericelaria, 102 fuliginaria, 101

Figure 80,82

Filbert, 197

kilbert Leaf Roller, 156

Fillet Brown Button, 176

Five-spot Burnet, 22

Five-spotted, 220

Flame, 56, 65, 122

Flame Carpet, 119

Flat Lackey, 47

flavicaput, 208

flavifrontella, 210 
floslactis, 210

Flounced, 149

Flounced Minor, 73

Flounced Rustic, 86

Flounced Thorn, 106

formosella, 225

Fork-stripe, 179

Forked Red-bar, 157

Forskalian, 181

Forster's, 203

Forsterian, 156

Four Angles MI, 112

Four-band Carpet, 118

Four-footed, 199

Four-spot M, 95

Fourospot Lackey, 48

Four-spotted, 192

Four-spotted Black, 225

Four-spotted 13rown, 226

Four-spotted Gold, 206

Fox, 37

Fox Tail, 66

Francillonian, 185

Freckled August Thorn. See A ugust Thorn, 105

Freckled Broad Bar. See Barred

Umbre, 113

Fringe, 85

Frischian, 195

Fritillaries, 5

Frosted Orange. See Mottled

Orange, 86

Frosted Green, 83

Fuesly's, 207

Full-spotted Ermine, 197

fulvescens, 210

Fulvescentine, 210

Fulvous Sealed, 169

Eumea, 44

Bombycella, 45

muscella, ib.

nitida, 44

pectinea, 45

pulla, 44
Funereal, 197

fusco-viridella, 207

Furbelow M. See Herald M, 82

Fyeslella, 207

\section{G}

Gall Fly Ilawk, 28

Galium Carpet. . Sec Bedstraw Carpet, 119

Gazzen1s, 211 alvearia, $i b$. cereana, ib.

Gamma Mi, 93

Garden China-mark, 150

Garden Moth, 53

Garden Pebble, 151

Garden Rustic, 61

Garden Veneer, 217

Gastroracira, 39

Ilicifolia, ib.

Populifolia, ib.

Quercifolia, ib.

Gate-keeper B, 13

Gelatella, 196

Gemmed, 182

Gentian, 160

Geoffroy's, 194

Grometra, 105

Alniaria, ib.

angularia, 106

Canaria, 105

Carpiniaria, 106

delunaria, 107

erosaria, 105

fuscantaria, 106

illunaria, ib.

illustraria, 107

Juliaria, 106

lunaria, ib.

ochraria, 105

Quercaria, 106 
INDEX.

Quercinaria, 105

sublunaria, 107

GEOMETRIDLE, 101

GLOMLIRINA, ib.

Georgian Grizzle B, 20

Ghost Swift, 29

Gigantic Veneer, 219

Gipsey, 39

firdle, 110

firl, 100

GLEA, 62

polita, 63

rubiginea, 62

rubricosa, ib.

Satellitia, ib.

spadicea, 63

subnigra, ib.

Vaccinii, 62

Glanville F, 6

Glaucous, 55

ilaucous Sheers, 67

Gleiche's, 206

Glimmerer, 65

GLYPHISTA, 180

caudana, ib.

effractan $a$, ib.

emargana, ib.

excavana, ib.

ochracea, $i b$.

jNopirRIA, 48

rubricollis, ib.

inat IIawk, 28

joddess F, 7

icedart's, 200

jold-banded, 171

iold-brindled Purple, 226

iold-barred, 172

iold China-mark, 153

wolden Eye B, 14

jold Four-spot, 101

rold-fringe, 148

rold I V, 200

iold I WV, ib.

bold Spangle, 94
Gold Spot, 94

Gold-striped Sable, 225

Gold ' lail, 41

Gold Tongue, 83

Golden Band, 200

Golden-banded Pigmy, 206

Golden Carpet, 119

Golden Copper B, 16

Golden Dot, 203

Golden Ear, 71

Golden Green M, 94

Golden Hair Streak. Sce Brown

Hair Streak B, 14

Golden Heath Eye. See Golden Eye 13, 14

Golden Marbled I3, with black eyes. See Wall B, 12

Golden Meadow Eye. See Meadow Brown $B, 13$

Golden IRibband, 200

Golden Rod B, 17

Golden Sallow, 85

Golden Speckled-black, 226

Golden Swift, 29

Golden Y, 93

Golden $\gamma$ MI, (Wilkes.) See Gamma, 93

Goldilocks, 79

Gonepteryx, 1 Rhamni, $i b$.

Gontrna, 86 flavago, ib. luteago, ib. micacea, $i b$.

Gooseberry M. See Magpie, 124 Gooseberry M, (Wilkes.) See L. Moth, 113

Gooseberry-leaf Roller, 156

Goose Feather, 209

Goose Foot, 117

Goth Moth, 30

Gothic, 67

Gothic Brocade, 8 .

Gothic Dart, 53 
Gracillania, 227 anastomosis, $i b$. cinerea, ib. elongella, 228 hemidactylella, ib. leucapennella, 229 Meleagripennella, 227 nebulea, ib. ochrachea, 228 prceangusta, 229 purpurea, 228 roscipennella, 229 rufipennella, 228 semifascia, ib. stigmatella, ib. substriga, ib. Thunbergella, ib. versicolor, ib. V. flava, 227 violacea, 229

Gramaresia, 60 Uilinea, ib. trilinea, $i b$.

Grand Surprise, or Camberwell Beauty, (Harr.) See Willow B, 9

grandipennis, 208

Graphiphora, 54

albimacula, 56

augur, 54

baja, 55

brunnea, ib.

candelisequa, $i b$.

C. nigrum, 56

crassa, 54

depuncta, 55

erythrocephala, ib.

festiva, 56

latens, 54

lunulina, ib.

musiva, 56

plecta, 56

pyrophila, 54

punicea, 56 renigera, 54

rhomboidea, ib. triangulum, 55 tristigma, $i b$.

Grass E'gger, 37

Grass Lmerald, 109

Grass Emerald, (IIaw.) See Green Carpet, $i b$.

Grass livulet, 138

Grass Wave, 116

Gray Dagger, 79

Grayling 13, 12

Greasy F, (IIarr.) See Scabious $\mathrm{F}, 6$

Great Argus, See Wall B, 12

Great Brocade, 76

Great Brown, 157

Great Brown Bar. See Old Lady MI, 99

Great Carpet, 111

Great Double Bar, 174

Great Lrmine, 43

Great Fritillary B, (Wilkes.) See Silver Streak F, 8

Great Fritillary 13, with silver spots, (Wilkes.) See Darkgreen $\mathrm{F}$, ib.

Great Hook-tip, 157

Great Kidney, 99

Great or Large Magpie M. Sec Magpie, 124

Great Navew B, 4

Great Oak Beauty. See Oak Beauty, 111

Great Raven Feather, 208

Great Red Underwing. See WVife, 99

Great Silver-streaked Golden F, ( $P_{\text {et.Pap.) See Silver Streak }}$ F, 8

Great Silver-streaked Orange $F$, (Pet.Pap.) See Silver Streak F, ib.

Great Streak Skipper B, 21 
Great 'Tiger, 42 Great Tiger, 42
Great Tortoise-shell B. See
Elm B,9

Great White Butterfly, (Albin.) See Early Cabbage, 3 Great White Cabbage 13, (Pet. Pap.) See Cabbage B, $\boldsymbol{3} b$. Greater Brindled Brown, 190 tireater Silver-spotted F, ( Raii.) Sce High Brown F, 8 Greater Silver-streaked F, (Raii.) See silver Streak k, ib.

Greek-lettered Gold, 200

Green Arches M. See Jasper, 76

Green 13. See Green Hairstreak $\cdot B, 16$

Green Brindled Crescent. Sec Hawthorn, 75

Green Brindled Dot. See Olive Dot, 74

Green l3rown M. Sce Green Carpet, 109

Green Calodxnia, 93

Green Carpet, 109, 118

Green Chequered White 13, (Haw.) See Rocket B, 4 Green Forester, 22 Green Fly, or Bramble F. See Green Hair-streak B, 16 Green Hair-streak B, $i b$.

Green Long-horn, 195 Greenish-marbled Half-mourner, (Pet. Gaz.) See Rocket 13, 4 Green Pug, 132

Green-shaded, 211 .

Green Silver Lines, 155

Green Tuft, 179

Green-veined White B, (IIarr.) See Navew B, 3

Grey $A$ rches, 76

Grey Birch, 113

Grey Bright Eye, 59

HadenA, 66 adusta, 67 amica \&66 Capsincola, 68 contigua, 67 Cucubali, 68 Genista, 67 glauca, ib. leucostigma, 68 Lithoriza, ib. oblonga, 67 obscura, ib. ochracea, 68 
INDEX.

plebeia, 68

remissa, 67

Saponaria, 69

satura, 67

Thalassin $a, i b$.

Hair Streak. See Brown Hair Streak B, 14

Hairy-horn, 66

Hairy-horned Wainscot. See Bristle-Thorn M, 86

Halbert, 53

IIalf-mourner. See Dwarf Lutestring, 82

Half-mourner ( $R a y)$. See Marbled White $\mathbf{B}, 12$

HAT.IA, 113

Vauaria, ib.

Vau nigraria, ib.

HАMA, 71

basilinea, ib.

connexa, $i b$.

testacea, ib.

Hampstead B, 10

Handley's Small brown Fritillary. See Dingy Skipper B, 20

Hare, 78

Harmony, 72

Harpalyce, 119

biangulata, 120

Corylata, ib.

fulvata, 119

Galiala, ib.

ocellata, 120

quadriannulata, $\$ b$.

silaceata, ib.

subtristala, ib.

sylvaticata, ib.

tristata, ib.

unangulata, $i b$.

unilobata, 119

Ifarris's, 201

Hastian, 173

IIaworth's, 202

Haworth's Plume, 231

Haw thorn, 37, 75

IIawthorn 13,5

Hawthorn Ermize, 198

Hawthorn Leaf Roller, $\mathbf{1 5 6}$

Ilawthorn M (Wilkes). See Lunar Thorn, 106

Hazel, 100

Hazel Leaf-roller, 155

IIazel Red, 202

Heart and Club Rustic, 50

Heart-bearer, 95

Heath Fritillary $\mathbf{B}$ (Wilkes.) See Yellow Crescent F, 6

Ieath Rivulet, 137

Heath MI (Wilkes). See Brown Heath, 101

Heath Veneer, 216

Hebe, 43

Hebrew, 57

Hedge Bill, 220

Hedge-Eye with double specks, See Gate Keeper 13, 13

HецionнobUs, 69

leucophous, ib.

Popularis, ib.

Hectotris, 9.5

dipsacea, $i b$.

marginata, ib.

peltigera, ib.

HeMERoPUILA, 112

abruplaria, ib.

Нвм⿱т⿲丶丶㇒木

Cythisaria, ib.

smaragdaria, ib.

vernaria, $i b$.

IIEPIALID E, 29

Iiepiales, ib. carnus, ib.

hectus, ib.

II umuli, ib.

lupulinus, ib.

sylvinus, 30

Velleda, 29 
INDEX.

erald MI, 82

ER1BEIA, 202

Clerckella, 203

cognatella, ib.

Forsterella, ib.

Haworthella, 202

humerella, 203

nivella, ib.

punctaurella, ib.

semiaurella, ib.

simpliciella, ib.

unipunctella, ib.

IESPERIDAE, 20

ETERORENA, 45

Asellus, ib.

tBEnNIA, 103

capreolaria, ib.

connectaria, ib.

defoliaria, ib.

prosapiaria, ib.

bernian, 74

igh Brown F, 8

igh Brown $\mathbf{F}$ (IIarr) See

figh Browa $\mathrm{F}, \mathrm{B}$

IIMERA, 104

pennaria, ib.

IPРА Rсн1А, 12

Egeria, ib.

Aleyone, ib.

drcanius, 14

Blandina, 13

Cassiope, $i b$.

Davus, 14

Galathea, 12

Hero, 14

Hyperanthus, 13

Janira, ib.

Ligea, 13

Hera, 12

Megara, ib.

Mnestra, 13

Pamphilus, 14

Phodra, 12

Polydama, 14
Semele, 12

Tithonus, 13

IIIPParchus, 108

Papilionarius, ib.

Hispid Beauty, 104

Hoary Double Crescent, 183

Hoary Grey, 211

Iloary Plume, 230

Hoary Sealed, 169

Joffmanseggian, 182

Hook-tip Blotch-back, 166

Hook-tipped Streak, 166

Hooked Marble, 167

IIooked-marked Straw, 185

Hook-tipped, 193

Hook-tip Veneer, 219

IIolly 13. See Green Hair Streak

B, 16

Holmian, 158

Iloney, 211

Iloney Comb, $i b$.

Ioneysuckle 13, 11

Honeysuckle Lobe, 131

Hornet Hawk, 27

Hornsey Beauty, 121

Horse-chestnut, 129

Horse-shoe, 191

Howard's IV'hite B. See leally Turnip 13, 3

IIübner's, 190

Hübner's Veneer, 218

Humming Bird Hawk, 26

IYdnocAmpA, 150

Lemnata, $i b$.

literalis, ib.

Nymphacata, ib.

Polamogata, ib.

Sambucata, ib.

Stratiotata, 151

HYPENA, 145

crassalis, $i b$. obesalis, $i b$. proboscidalis, ib. rostralis, ib. 
HYPERCAMPA, 42

Dominula, ib.

IItrercallia, 186

Christiernana, ib.

11 чровтмх, 39

dispar, ib.

HҮRI, 391

auroraria, ib.

\section{I}

Ianthe, 49

Ichneumon Hawk, 28

Ilex leaf, 39

IzxтитA, 211 colonella, ib.

InCURVARIA, 223 musculella, ib.

Oehlmanniella, 224 pectinella, ib.

spuria, ib.

tripunclella, $i b$.

Indefinite, 172

Indistinet, 203

Indistinct Drab, 170

Indistinct Streaked, 177

Ingrailed (IIarr.) See Pine

\section{Gem, 112}

Inlaid Veneer, 216

Ivo, 22

Gtobularia, ib.

Statices, $i b$.

Inscription, 93

Intermediate, 57

Iron Brown B, 14

Iron Notehwing, 180

Island Carpet, 130

Italian Twin Spot, 75

\section{J}

Jacquinian, 163

Jagged-winged Comma.

Comma B, 8
Jasper, 76

Jot, 93

July Arrach M, (IVilkes.) Sel July Spinach, 123

July Chi, 77.

July Hightfyer, 126

July Ilighflyer Likeness. \$ May Highflyer, 126

July Lackey; 47

July Ringlet, 14

July Sallow M. See July Hight flyer, 126

July Spinach, 123

July Thorn, 106

Junction Carpet, 121

Juniper, 130, 188

Juniper Pug, 133

K

Kent, 170

Kent Blue B, 18

Kent Ermine, 198

Kent Thorn, 107

Kentish Glory, 36

Kidney, 54, 73

Kidney Silver Cloud, 65

Kitten, 32

Kittenet, $i b$.

Kleman's, 201

Knock's, 225

Kuockella, ib.

Knot-grass. See Dock II, 80

L

L. Moth, 113

Lace Border, 140

Lace-wing, 45

Laced Borber, (IIarr.) See Li? Border, 140 
INDEX.

ackey, 39

ICIA, 41

cenosa, $i b$.

ambdella, 210

АบPUONIA, 225

amanella, 227

alrella, 226

aus'opurpurella, ib.

uurogutiella, 227

bistrigella, ib.

capitella, 225

corticella, 226

Ravipunctella, ib.

Helwigella, ib.

narginepunctella, ib.

melanella, ib.

prelatella, 225

purpurella, 226

rubro-aurella, ib.

rupella, 225

sanguinella, 227

Seppella, ib.

subpurpurella, 226

IMPROPTERYX, 122

badiata, ib.

piceala, ib.

suffir $u$ mata, ib.

ince, 73

ppet, 39

IRENTAs, 117

Uipunctaria, ib.

cervinaria, ib.

Chenopodiala, ib.

multistrigaria, ib.

age Brown, 174

ige Blue. See Arion 13, 18 ryge Blue-bordered. See Clifden Carpet,(Harr.V.MI.) 125 age C'arpet. See Great Carpet, III

ste China-mark, 150

rge Copper B, 16

fre Dark Shark. See Night-
Large Einerald, (IIarr.) Sec Butterfly Emerald, 108

Large Four-spolted. See AI. chemist, 99

Large Garden White B, (I Iarr.)

See Cabbage B, 3

Large Grey, 212

Large Grey Elm, 170

Large Ileath (IIaw.) See Gatukeeper B, 13

Large Holly, 175

Large Lace Border, I41

Large Marbled, 174

Large Mocha. See Black Annulet, 129

Large Pale Shark. See Shark, 90

Large Ranunculus M. See Yellow Girdle, 77

Large Skipper, (Harr.) See Clouded Skipper B, 21

Large Streaked, 186

Litlye Tortoiseshell $\mathrm{B}$, (IVilhes.)

See EIm B, 9

Large Twin-spot. See I'rivet Twin-spot, 118

Large IVainscot, 87

Large White B, (ITaw.) See Cabbage 13, 3

Large White Garden B,

(Wilkes.) See Cabbage B, 3

Large White Plume, 229

Lasiocadipa, 37

Dumeti, ib.

Medicaginis, ib.

Quercus, ib.

Iloboris, ib.

Rubi, ib.

Trifolii, ib.

Lathamian, 175

Latreille's, 195

Latticed Ileath, 139

Lead Argus. Sec Lead Blue B, 19 
Lead Belle, 116

Lead 13lue B, 19

I.ead-coloured, 178, 209

Lead-coloured Lackey, 47

Lead-coloured Pug, 134

Leaden Drab, 57

Leaden Veneer, 216

Least Black Arch, 154

Least Carpet, 138

Least Pygmy, 205

Lechean, 174

Ledian, $\mathbf{J} 64$

Leioca м PA, 34

dictae $a$ ib.

dictcoides, ib.

Semon Plume, 230

Lemon Sallow, 85

Leridocena, 223

Chenopodiella, ib.

mediopectinella, ib.

setella, ib.

Taurella, $i b$.

Lеттоовамын, 179

futvomixtana, 180

irrorana, ib.

literana, 179

scabrana, 180

squamana, 179

tricolorana, $i b$.

Lesser Bell, 146

Lesser Blotchback, 161

Lesser Cream Wave, 141

Lesser Crimson Under-wing, (IIaw.) See United, 100

Lesser Dotted Rustic, 61

Lesser Drab, 169

Lesser Flat Body, 187

Lesser Grass Wave. See Grass

Wave, 116

Lesser Grey Elm, 170

Lesser Long-cloak, 160

Lesser Lutestring. See Dwarf

Lutestring, 82

Lesser Pearl, 152
Lesser Purple, 188

Lesser Satin Carpet. See Twin Point Carpet, 82

Lesser Silver spotted Fritillary,

( Ray.) See P'rincess F, 7

Lesser Silver-spotted or Riga F

(Pet. Pap.) See Princess F, ?

Lesser spotted Pinion. See

Twin-spot Pinion, 84

Lesser spotted IVhite Venned $B$

(Pet. Pap.) See Naven B, 3

Lesser Tawny Crescent, 210

Lesser Tortoise Shell B. Se Tortoise Shell B, 9

Lesser White Caubage $13,(P c h)$ Pap.) See 'Turnip B, 3

Lesser White Double-spotte.

B, (Pet. Pap.) See Turai B, 3

Lesser White Treble-spotted II

Var. q, (Pet. Pap.) St Early 'Turnip B, 3

Lesser White Unspotted B, Val

t. (Pet, Pap.) See Eorly

I'urnip B, 3

Letter $1 ., 72$

Lettered China Mark, 150

Lettuce Shark, 90

LEU COM $\AA, 41$

Salicis, ib.

Vau-nigra, ib.

LevCopHasia, 4

Loti, ib.

Leucania, 87

arcuala, ib.

comma, ib.

fluxa, 88

geminipuncta, $i b$.

impura, 87

littoralis, $i b$.

neurica, 88

obsoleta, 87 
ochracea, 88

pallens, $i b$. pallida, ib. pudorina, 89 punctina, 87 pygmina, 88 rufescens, ib. sutfusa, ib. unipuncta, 89 awenhoek's, 207 Att-brindled Brown, 190 litmbrindled Woollen, 223 ditCrimson Under-wing. Sce Promised, 100 tht Emerald, 108 ht Feathered Rustic, 53 hot Knot-grass, 80 hit Marbled, 184 fhi Mottled Beauty. See Hottled Carper, 111 hht Negro, 45

\section{Hat Orange Uuder-wing,}

(Haw.) See Hazel, 100

hit Silver-stripe, 162

ditt-streak, 194

Gift-striped Edge, 168

ht $W$ ainscot, 88

ac Beauty, 107

rucodes, 45

Testudo, $i b$.

pe Hawk, 24

me Moss M. See Brussels lace, 110

he Speck, 135

Yellow, 155

Dart, 52

Grey, 212

ei Buff, 98

eless Hook Tip, 144

\section{k, 71}

nowus's, 206

sorice Burnet, 23

er's, 189

THOSIID
Lithosis, 46 Aureola, ib. complana, 47 depressa, $i b$. fava, ib. Gilveola, ib. griseola, ib. IIelveola, ib. muscerda, ib. plumbeolata, $i b$. quadra, ib.

Little Black, 191

Little Blossom, $i b$. Little Blue Argus, See Alexis 13, 18

Little Bull, 223

Little Emerald, 109

Little Eyelet, 199

Little Greek 0, 114

Little Swallow, 34

Little Thorn, 115

Liver, 66

Livid Plume, 230

Livid Slender, 229

Livid Swift, 29

Lobster-clawed, 193

Lobophona, 131 costastrigata, ib. dentistrigata, $i b$. hexapterata, 132 polycommata, 131 sexalisata, 132 viretata, 131

Lœflingian, 181

Logian, 170, 178

London Eye, See Wall B, 12. London Lye, with a brown list. See Wall B, 12 Long-horned, 186 Long Legs, 153 Long-winged, 170, 193 Long-winged Pearl, 152 Long-winged Pug, 134 Long-winged White Back, 199 
$\begin{array}{rr}\text { Looping Chimney } & \text { Sweeper, } \\ \text { (IIaw.) } & \text { See Chimney }\end{array}$ Sweeper, 136

Lorrodenus, 174 ministranus, ib. subfasciana, ib.

Lornonotus, 192 fusciculellus, $i b$.

1.0PHOPTERY X, 34 camelina, ib. carmelita, $i b$. cuculla, ib.

I.OZOGRAMMa,-127 petraria, $i b$.

Lozorera, 185 alternana, $i b$. Fabriciana, ib. Francillana, ib. Siraminea, ib.

LOZOTENIA, 156 Acerana, 158 Avellani, 156 biustulana, 157

Branderiana, ib. Carpiniana, 156

Cerasana, ib. cinerana, 158 Corylana, 156 costana, 157 croceana, 158 cruciana, ib.

Forsteriana, 156 fulvana, 157

fuscana, ib.

Grossulariana, 156

Grotiana, 158

llolmiana, ib. lavigana, 156 Modeeriana, 157 obliquana, ib. oporana, ib. Oryacanthana, $i b$. Ribeana, 156 Roborana, 157
Rosana, 156 Schreberiana? 158 subocellana, 157 trifasciana, 158 Viburnana, 157 $X y l o s t e a n a, i b$.

Lucid Straw, 193 lucidella, 210

Lucidine, 210

Lunar Marbled, 35

Lunar-spotted Pinion. See Crescent Pinion, 84

Lunar Thorn, 106 Lunar Uunderwing, 48, 58 lunaris, 210 Lundian, 166 Lurker, 118 Lush Carpet; 121 lutarea, 208 lutarella, 210 Lutarine, ib. LYCENa, 16 Chryseis, ib. dispar, $i b$. Hippothes, 17 Phloeas, 16 Virgaurex, 17

LYCENID E, 114 Lychnis, 68 LYTЕ $A, 49$ Umbrosa, ib.

\section{M}

Macania, 143 alternata, ib. liturata, $i b$. notata, $i b$. proeatomata, 144 subrufata, 143 unipunctata, 144

Márochí^, 193 aristella, 194. 
bicostella, 194

fasciella, 193

inarginella, 194

palpella, ib.

parenthesella, 193

ficnoolossA, 26

Stellatarum, ib.

Idder Hawk, 25

DOPA, 146

Salicalis, ib

isin, 102

fevillacearius, $i$.

agpie, 124

hid of Honour MI, 110

biden's BIush. See Buff Argus, 115

shogany, 63

le Straw B. See Primrose 13, 1

dllow, 117

illow, 13, 20

Hlow Leaf, 203

incipiuas, 4

Cardamines, ib.

Daplidice, ib.

Iмrstri , 69

allidilinea, 70

albioolon, ib.

Aliena, ib.

Brassica, ib.

Chenopodii, ib.

hัง 69

nigricans, 70

deracea, 69

Persicaria, 70

Pisi, 69

splendens, ib.

uasa, 70

any Marked, 126

any Spotted Yellow, 222

iple, 34, 158

ubled Beauty, 81

irbled Carpet, 121

irbled Chestnut, 177

orbled Clover, 95
Marbled Coronet, 75

Marbled Dog's Tooth, 172

Marbled Green. See J3ishop, 80

Marbled J.ong-cloak, 159

Marbled Knot-horn, 214

Marbled Plume, 231

Marbled I'ug, 135

Marbled Short-cloak, 167

Marbled Single Dot, 165

Marbled White 13, 12

Marbled White Line, 97

Marbled White Spot, 97

March Dagger, 197

Margin Dotted, 226

M A IGARITIA, 151

angustalis, 152

centrostrigalis, ib.

cilialis, 153

cineralis, ib.

diversalis, 151

clutalis, 154

ferrugalis, 153

fimbrialis, ib.

flavalis, ib.

glabralis, 152

hyalinalis, ib.

limbalis, ib.

longalis, ib.

longipedalis, 153

lutealis, ib.

margaritalis, 154

ochrealis, 15 's

palealis, 152

pallidalis, $i b$.

pulveralis, 153

sericealis, $i b$.

terminalis, 152

tetragonalis, 153

Thapsalis, 152

uliginosalis, 153

Verbascalis, ib.

verticalis, 152

Marginea, 210

Margined Pearl, 153 
Margined Veneer, 217

Margivian, 184

Marmoress, (Ifarr.) See Marbled White B, 12

Marbled F, (Bing.) See Scabious $\mathrm{F}, 6$

Marsh Ringlet $\mathbf{B}, 14$

Marshall's Plume, 229

Mask, 101

May Fritillaıy, ( $($ ay. ) See Yellow Crescent $\mathrm{F}, 6$

May High-fiyer, 126

May Straw $\mathbf{F}$. See Black Crescent F, 6

Mazarine Blue B, 17

Meadow Brown B, 13

Meal Moth, 147

Mealy Knot-horn, 215

Median, 222

Medic Egger, 37

Me ferle's, 225

Megerella, $i b$.

Melanippe, 125

hastata, ib.

Met.anoleuca, 197

dodecea, ib.

Echiella, ib.

funerella: $i b$.

pusiell $\alpha, i b$.

MELIA, 211

bipunctana, ib.

flammea, ib.

sericea, ib.

socia, $i b$.

MIE.IтжA, 5

Artemis, 6

Athalia, ib.

Cinxia, ib.

Dia, 7

Euphrosyne, ib.

Maturna, ib.

Pyronia, 6

Selene, 7

tessellaia, 6
Merian's, 207

Metallic, $i b$.

Michositia, 203

atri-capitella, 203

aurella, ib.

aurofasciella, 206

cinercopunctella, 203

exiguella, $i b$.

flosluctella, 205

Gleichella, 206

guttella, 203

mediofasciella, 205

nigrella, 204

nigraciliella, ib.

obsoletella, 203

posticella, 205

pulchella, 204

pygmaella, 205

quadrella, 204

quadriguttella, 206

ruficapitella, 205

sequella, 204

sericiella, 205

stipella, 203

subbimaculella, 204

subbistrigella, 203

trimaculella, 204

unifasciella, ib.

violaceella, 205

Middle Feathered, 223

Middle Rivulet, 137

Mrana, 72

Ethiops, 73

fasciuncula, $i b$.

humeralis, ib.

latruncula, 72

literosa, $i b$.

minima, 73

rufuncula, ib.

strigilis, 72

terminalis, 73

Miles, 223

Miller, 78

Milkmaid, 109 
jiky, 190

woA, 136

Cherophyllala, ib.

Euphorbiata, ib.

inor Beauty, 72

inor Shoulder Knot. See

Osier, 83

int Beauty, 111

binute, 203

inutella, 224

inute Yellow Underwing. See Strawberry Tree, 95

iscella, 225

\section{HIELIA, 75}

albimacula, ib.

Aprilina, ib.

bimaculosa, ib.

compta, ib.

Oxyacantha, ib. titterbachian, 168

ixt Tawny, 180

ixt Argus. See Alexis B, 18 tocha. See Little Gireek $O$, 114

locha Stone, 114

odeerean, 157

\section{tor, 221}

fonmo, 99

мaura, $i b$.

orning Crescent F, 6

orpheus, 61

ist Common Small Blue B.

See $A$ lexis $\mathbf{B}, 18$

ther of Pearl, 152

sttled Beauty, 110

ttled Beauty, (Wilkes.) See

ispear Beauty, 125

ittled Bran, 173

ttled Carpet, 111

ttled Grey, 117, 165

ttled Orange, 86

ttled Pug, 133

ttled Red, 228

ttled Rustic, 61
Mottled Willow, 62

Mottled Woollen, 223

Mottled Yellow, 86

Mourning Carpet, 120

Mountain Iinglet B, 13

Mountain Veneer, 217

Mouse, 63

Mouse Brown Veneer, 215

Mouselet, 89

Muddy Ermine, 198

MI ugwort Shark, 91

Mulatto, 70

Mullein, 90

Mullein Wave, 140

Muranine, 212

Music, 65

Musive, 56

Muslin, 45

Myller's, 201

Myller's Nettle Tap, 148

Mчthima, 59

conigera, 60

grisea, 59

Lithargyria, 60

turca, 59

$\mathrm{N}$

N IENIA, 64

typica, ib.

Narrow-barred Carpet, 127

Narrow Grey, 212

Narrow Long-cloak, 160

Narrow Silver-dotted, 148

Narrow Veneer, 217

Narrow-winged Pearl, 152

Narrow-winged Pug, 135

Narrow-winged Red-bar, 158

Narrow-winged Veneer, 219

Navew B, 3

Neat, 191

Nebulous Slender, 227

Necklace Carper, 120 
Necklace Veneer, 215

Neglected Rustic, 60

Negro, 44

Negro Boy, 45

Nemromivs, 5

Lucina, ib.

Neseophila, 43

Plantaginis, ib.

Net Chestnut, 63

Net Wing B, 10

Netted Heath, (IIaw.) Latticed IIeath, 139

Netted llook-tip, 220

Netted 1'ug, 136

Nettle, 92

Nettle Tortoise Shell B. See Tortoise Shell 13, 9

Nerved Wainscot, 88

New Forest Wave, 143

Night Shade, 91

Nigricella, 208

NOCTUID $\bar{E}, 48$

NOCTUIN $\boldsymbol{A}, 46$

NoLA, 154

cucullatella, ib.

fuliginalis, 155

Monachalis, 154

strigulalis, ib.

Nonagria, 86

Canna, 87

crassicornis, ib.

pilicornis, 86

Typhe, ib.

Nonpareil, 206

Noted Pug, 134

Notudonta, 33

Dromedarius, $i b$.

perfusca, $i b$.

ziczac, $i b$.

NOTODONTIDAE, 30

November, (YIarr.). See Fea. thered Ihorn, 104

November, (IIaw.) See $\Lambda$ utumn Border, 130
November Dagger, 197

Nubilea, 196

Numarta, 45

Hemerobia, ib. munila, ib. senex, $i b$.

NumeniA, 113

pulveraria, ib.

Nun M, 96

Nutmeg, 70

See Nut-tree 'l'ussock, 40

$N Y M P I I A I D A, 5$

Nум户нци, 151

hybridalis, ib.

Nyssta, 104

hispidaria, ib.

0

Oak Beauly, 104, 111

Oak Carpet, 111

Oak Egger, 37

Oak Hook Tip, 144, 157

Oaken, 35

Obelisk, 130

Obelisk Dart, 53

Oblique-bar, 157

Oblique Barred Grey, 184

Oblique Carpet, 127

Oblique Stripe, 127

Oblong Gold-head, 208

Obscure Annulet, 129

Obscure Silver $\mathrm{Bar}, 162$

Obscure-striped, 228

Obscurella, 208

Obtuse Marble, 168

Ochre, 105

Ochre Wainscot, 88

Ochroleucella, 208

October MI, (Wilkes.) Se Feathered Thorn, 104

Oposists, 39

Potaloria, ib. 
INDEX.

ONTOPERA, 105

bidentata, ib. ICOPHORA, 206

limaculella, ib. arimia, ib.

Linneella, ib. metallella, 207

Rasella, 206

Schafferella, ib.

hlinan's Twin Spot, 224

1. Lady, 99

d Wainscot, 87

iella, 210

ive $\mathrm{MI}, 83$

ive $\mathbf{M},\left(\boldsymbol{H} \boldsymbol{I r}^{*} \mathrm{r}_{\mathrm{V}}\right)$ See Green Pug, 132

ive Carpet, 118

ve Crescent, 146

are Dot, 74

ivier's, 194

Nocen A, 215

henella, ib.

Cardui, ib.

arnella, ib.

Lotella, ib.

ainiosella, ib.

collea, ib.

anguinella, ib.

anusa, 98

rassiuscula, ib.

radirena, 99

udicra, 98

issoria, ib.

Dorabia, 130

'lilutata, ib. lositella, 224

hage M, (Wilkes.) See Plumb Orange, 107 tage and Black, 182 unge Barred Pearl, 184 Ginge Blotch Black, 206 hinge Lackey, 46 ange Sallow, 85 inge Spotted, 182
Orange Swift, 30

Orange Tip, or Lady of the Woods, (Wilkes.) Sec Wood Lady 13, 4

Orange T'ussock, 41

Orange Upperwing, 85

Orange Underwing, (Jilkcs.)

See Virgin, 100

Orange Underwing Companion. See Hazel, 100

Oroyes, 41

antiqua, il.

gonostigma, $i b$.

(Trion, 81

Orrach M, 74

Ontuosia, 67

cruda, 58

flavilinea, 59

gracilis, 57

instabilis, ib.

intermedia, ib.

litura, 58

Lota, 59

lunosa, 58

macilenta, 59

miniosa, 58

munda, 57

pallida, ib.

$\boldsymbol{P}_{\text {istacina, }} 58$

prsilla, $i b$.

sparsa, 57

stabilis, 58

Upsilon, 59

Ontrotelia, 186

sericea, ib.

venosa, ib.

OMthotenia, 171

aurofasciana, 172

bifasciana, ib.

bistrigana; ib.

fasciana, 171

fuligana, 172

furfirana, 173

II astiana, ib. 
marmorana, 172 micana, 171 nubilana, ib. obsoletana, 172 perfuscana, 171 Pinetana, 17\% politana, ib. pulchellana, ib. quadrimaculana, 171 subsequana, 173 undulana, 171 Urticana, $i b$.

Osier, 83

Our Blew Hair Streak. See Purple Ilair Streak B, 15

Our Ialf Mourner, (Pet. Mus.) See Marbled White B, 12 OURAPTERYX, 108

Sambucaria, ib.

Paciycnemia, 129

IIippocastanaria, $i b$.

Painted Lady, 10

Painter, 110

Pale Blue Argus. See Chalk Hill Jlue, 18

Pale 13lue. See Cupid Blue B, 19 Pale Brindled Beauty, (IIarr.) See Winter Beauty.

Pale Brown Hair Streak. See Blackthorn Hair Streak B, 15 Pale Brown Long-horn, 196

$1^{2}$ ale Brown Stripe Edge, 163 l'ale Checquered Brown, 196 Pale Clouded Y cllow B, (IIarr.) See Clouded Yellow 13, 2 Pale Comma, (P'ct. Pap.) See Comma 13, 3

Pale Cream IVave, 142

Pale Downy-horned, 196 Pale Drab, 170

Pale Grey, 21)

Pale Hook-tip Vencer, 219

Pale Leaden, 47

Pale Mocha Stone. See Birel Nocha, 114

Pale Oak Beauty, (IIarr.) Se Oak Carpet, 111

Pale Orange, 182

Pale Plume, 230

Pale Prominent, 35

Pale Purple Underwing, 226

Pale Quaker, 57

Pale Shining Brown. Set Shining Brown, 76

Pale Shoulder, 211

Pale Straw, 153

Pale Wainscot, 88

Pamplinla, 20

Bucephalus, 21

Comma, ib.

Linea, ib.

Paniscus, 20

Sylvanus, 21

Sylvius, ib.

Vitellius, ib.

Pancalia, 207

fusco-anea, ib.

fusco-cuprea, ib.

Leuwenhoekell $a, i b$.

Merianella, ib.

Panther, 124

P'anzer's Long J Jorn, 196

Panzerella, 210

Panzerine, ib.

Papllio, 1

Regina, ib.

Podalirius, ib.

I'APILIONIDA,

'атамesia, 179

bifiduna, ib.

cerusana, $i b$.

gnomana, ib.

subtripunctulana, ib.

tripunctulana, ib. 
renthesis, 193

\section{rrot Carpet, 126}

ykullian, 167

\section{Green, 155}

scock B, 9

ich Blossom, 81

acock, 143

acock's Eye. See Peacock 8,9

scock's Feather, 198

arl Border $F$, See Yellow Crescent F, 6

arl-bordered F, (IIarr.) Sce Prince $\mathrm{F}, 7$

irl-hordered Likeness,

(Harr.) See Yellow Crescent $\mathrm{F}, 6$

H Lackey, 47

arl Rustic, 62

arl Skipper B, 21

arl Straw, 154

arl-streak Veneer, 216

arl Underwing, 51

arl Veneer, 217

tas-blossom, 92

abble, 33

ctinated, 158

reble Hook-tip, 144

EXTHOPIERA, 44

migricans, ib.

Ruber, ib.

tazian, 170

ppered M. See Spotted Elm, 104

\section{FHicat.lia, 107}

Syringaria, ib.

ithus 4,36

serrata, ib.

IRONEA, 175

albicostana, 177

albipanctana, 176

albistriana, 177

albovittana, 176

esperana, 178 aulumnane, 177

bistriana, $i b$.

borana, 178

Boscana, ib.

brunneana, 175

Byringerana, 177

centrovittana, 176

combustana, 177

consimilana, 176

coronana, 177

costimaculana, 178

cristalana, 176

cristana, ib.

Desfontainiana, ib.

divisana, ib.

favillaceana, 177

fulvocristana, 176

fulvoviltana, ib.

latifasciana, 177

Logiana, 178

obsoletana, 177

plumbosana, 178

profanana, 175

radiana, 176

ramostriana, it.

reticulana, 177

rufana, 178

ruficostana, 177

Schalleriana, 178

similana, 177

spadiceana, 176

siriana, 175

strigand, 176

subcristana, 177

substriana, 175

subvittana, 176

trigonana, 178

tristana, 177

umbrana, 176

variegana, 179

vittana, 176

Pet, 64

Petasia, 35

Cassinea, ib. 
Petiverean, 163

I'Augian, 161

Puasiane, 116 plumbaria, ib.

Phibalsiteiy 126 angustata, 127 elutata, 126 lignata, 127 lineolata, ib. tersata, 126 vitalbata, ib.

Pниздоски, 186 Quercana, ib.

Phigalia, 103 pilosaria, ib.

Pilogorhona, 89 meticulosa, ib.

Phobe, 72

Phonix, 122

Phœnix Carpet, 120

Proxor'rnis, 167 Assectana, 168 harpana, 167 incarnana, ib. Milterbacheriana, 168 vevana, 167 nigromaculana, ib. Paykulliana, ib. Sesquilunana, ib. Sociana, ib. Subocellana, ib.

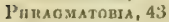
fuliginosa, ib. Phryganella, 197 Putmiociros, 184 rugosana,ib.

linveita, 212 Abietella, 214 advenella, ib. angustella, 213 bistriga, $i b$. consociella, ib. cristella, 215 diluta, 212

\author{
clutella, 213 \\ fascia, 213 \\ formosa, 214 \\ fusca, 215 \\ Gemina, 213 \\ legatella, 215 \\ marmorea, 214 \\ nebulella, 212 \\ obtusa, 214 \\ ornatella, ib. \\ palumbella, 215 \\ pinguis, 214 \\ Porphyrea, ib. \\ Rhenella, ib. \\ Roborella, ib. \\ rufa, 213 \\ semirufa, ib. \\ tumidella, ib. \\ Pnytometra, 97 \\ enea, ib.
}

Pica-pennis, 208

Pied-cuat, 154

Pieris, 5

Cratagi, ib.

Pig Hawk, 26

Pigmy $X, 164$

Pine, 74

Pine Gem; 112

Pine Hawk, 25

Pine Knot-horn, 214

Pine Lappet, 39

Pine Procession, 38

Pinion Snout, 145

Pinion-spotted Pug, 135

Pinion-spotted Yellow, 139

Pink-bar, or, I'ink-barrel Sat low, 85

Pitch Brown, 122

Plain August Thorn. See Au gust Oak, 105

Plain Brown Bution, $17 \mathrm{~b}$

Plain Drab, 186

Plain Gold Fringet, 163

Plain Knot-horn, 215 
INDEX.

ain Pug, 134

sin Red, 228

ain Silver Fringe, 163

ain Wave, 141

in Yellow, 155

antain Fritillasy B. See Glanville F, 6

LATYPTERICID.E, 144 LATYPTERYX, ib.

cultraria, ib.

Lacertula, ib.

ebeian Hawk, 25

rasant MI, 121

leasant Gold, 227

flum, 154

lumb Orange, 107

lumb IIair Streak 13, 15

lumber, 125

lumiferous, 35

uustu, 93

aurifera, 94

biloba, $i b$.

bimaculata, 93

bractea, 94

chrysitis, ib.

circumflexa, ib.

Festuca, ib.

Gamma, 93

interrogationis, ib.

lota, $i b$.

urichalcea, 94

Percontationis, 93

CTtLLLA, 219

Acinacidella, ib.

esperella, 220

denlella, 219

nemorella, ib.

scabrella, $i b$.

subfalcatella, 220

PILOCAMPA, 38

Populi, ib.

- CHucunosa, 173

traculana, ib.

saurana, 174 piceanu, 173

semifuscana, ib.

Solandriana, ib.

Sparmanniana, ib.

Udmanniaua, ib.

Peciloruasia, 142

marginata, ib.

Pointed Bar, 165

1’oxis, 76

Advena, ib.

bimaculosa, ib.

Chi, 77

dysodea, ib.

flavocincta, 86 .

ITerbida, 76

nitens, ib.

occulta, ib.

Polymita, 77

seladonia, ib.

serena, $i b$.

Templi, 76

tincta, $b$.

Poly Plume, 231

Pozyommatus, 17

Acis, 17

Adonis, 18

Agestis, 19

Aleon, 18

Alexis, ib.

Alsus, 17

Argiolus, ib.

Argus, 19

Arion, 18

Artaxeries, 19

Corydon, 18

Dorylas? ib.

Eros, 19

Icarius, 18

Salmacis, 19

Titus, ib.

PoLyirisia, 121

amanata, ib.

centum-notata, ib.

comma-notata, ib. 
concinnala, 121

immanata, $i b$.

marmorata, $i b$.

perfuscata, ib.

saturata, ib.

Pol.y pooon, 146

barbalis, ib.

cribralis, $i b$.

derivalis, ib.

emortualis, ib.

nemoralis, ib.

tarsicrinalis, ib.

Pontin, 2

Brassica, 3

Chariclea, 3

Metra, 3

Napaæ, 4

Napi, 3

Iape, 3

Sabellice, 4

Poplar, 189

Poplar 13. 11

Poplar Grey, 78

Poplar Hawk, 23

Poplar-leaf, 39

Poplar Lutestring, 82

Poplar Slender, 229

Porcelain, 202

Porphyry, 67, 74, 149

Porphyry Knot-horn, 214

Porrectaria, 209

albicosta, $i b$.

Anatipennella, ib.

argentula, ib.

Gallipennella, ib.

leucapennella, $i b$.

linenlea, ib.

achrea, ib.

ornatipennella, $i b$.

'ontunsta, 41

auriflua, 42

chrysorrhea, 41

Portland, M. See Pine, 74

Portland Veneer, 216
Powdered Knot-horn, 212

Powdered Quaker, 57

Powdered 1Rustic, 62

Powdered Straw, 188

Powdered Veneer, 217

Powdered Wainscot, 89

Pretty Brocade, 67

Pretty Crimson, 46

Pretty Fan-foot Wave, 140

Pretty Widow $\mathrm{OI},\left(\boldsymbol{D}_{\text {on. }}\right)$ So

Netted Pug, 136

Primrose, 56

Primrose B, 1

Primrose Yellow, 194

Prince $\mathrm{F}, 7$

Princess $\mathrm{F}$, ib.

Privet Hawk, 25

Privet 'Twin Spot, 118

Procession, $3 \mathrm{~b}$

l'romised, 100

Prominent M, (IIarr.) S Seraphim, 132

Prophetess 13, 11

Pseudotomia, 162

atromargana, ib.

atropurpurana, 163

aurana, 164

comilana, ib.

compositella, ib.

concinnans, 163

dorsana, 164

fraternana, 162

Gundiana, 164

Jacquiniana, 163

Lediana, 164

nigricana, 163

nitidana, 164

obseurana, 162

Petiverella, 163

I'opulana, 164

proximana, 163

puncticostan $a, i b$.

sequana, 162

simpliciana, 163 
strigana, ib.

Strobilella, 162

Trauniana, 163

trigonana, 164

EILURA, 40

Monacha, ib.

sodos, 101

alpinata, $i b$.

trepidaria, ib.

SYCuE, 44

fusca, ib.

Prrophonvs, 229

bipunctidactylus, ib.

calodactylus, 231

citridactylus, 230

didactylus, 231

fuscodactylus, 229

galactodactylus, 230

heterodactylus, 231

leucodactylus, 230

lunadactylus, ib.

microdactylus, 231

migadactylus, 230

monodactylus, ib.

niveidactylus, ib. ochrodactylus, ib.

pallidactylus, ib. pentadactylus, $2 \cdot 29$

phroodactylus, 230

pterodactylus, ib.

punctidactylus, 231

rhododactylus, ib.

spilodactylus, 229

tephradactylus, 230

tesseradactylus, 231

letradactylus, 230

tridactylus, $i b$.

trigonodactylus, ib.

тиловтома, 35

lalpina, ib.

THLPHORA, 35

tariegata, ib.

irenolosin, 174

Lecheana, ib.
РтуснотоDA, 140

decoraria, ib.

dilutaria, ib.

contiguaria, 141

fimbriolate, 140

immutata, 141

incanata; 140

limboundata, 141

lividata, 140

ornata, $i b$.

rubricata, 141

trigeminata, 140

Purple, 43, 174

Purple and Gold, 149

Purple-bar, 119

Purple-bar Rivulet, 138

Purple-barred Yellow. See

Yellow Purple Bar, 116

Purple Black, 163

Purple-bordered Gold, 139

Pupil Dart, 52

Purple-edged, 199

Purple-edged Copper, (IIaw.)

See Golden Copper 13, 16

Purple Emperor, (IIArr.) See

Eimperor 13, 11

Purple Flat Body, 187

Purple Hair Streak B, 15

Purple Iligh-0yer, or limperur

of the Woods. See Emperor

b, 11

l'urple Red Wave, 141

Purple Shades, 93

P'urple Thorn, 107

Purple Underwing, 226

Purple White Back, 199

Purple While Streak, ib.

Purplish Knot Iorn, 215

Puss, 32

P'vgenA, 30

bucephala, ib.

Pygmy silver Bar, 205

Pygmy Veneer, 217

$P Y \| A L I D A E, 145$ 
Pyinalis, 147

farinalis, $\mathfrak{a} b$. glaucinalis, ib. marginatus, $i b$.

Pyrastran, 157

Pyrausta, 149

cespitalis, 150

ostrinalis, 149

Porphyrialis, ib.

punicealis, ib.

purpuralis, $i b$.

sordidalis, 150

Руногнгі, 63

tetra, $\overrightarrow{i b}$.

Tragopogonis, ib.

Pyrophilous, 54

Quadri-punctella, 224

Queen B, I

(queen of England F. See Dark Green F, 8

Queen of Spain F. See Princess $F, 7$

R

Raddon's Skipper B, 21

Radiated, 221

Radiated Heath, (IIaw.) See

Latticed Heath, 139

Ranunculus M. See Crowfoot, 77

Ray's, 201

Ray's Blue Ifair Streak. See Purple IJair Streak 13, 15

Rayed Buff, 44

Rayed Veneer, 217

Reaumur's Long Horn, 195

Kecluse, 31

Recurvania, 193

falciformis, ib.

lucidella, 193

nebulella, ib.

ochroleucella, ib.

rufescens, $i b_{\text {. }}$

Silacella, $i b$,

Red and White Bar, 202

Red-barred Gold, 226

lied-barred Grey, 172

Red-barred Pug, 133

Red Belted 1lawk, 28

Red-brindled, 210

Red blotch-back, 159

Red or Reddish Buff, 97

Red Chestnut, 62

Red Cross, 158

Red Feather, 210

Red Fringe, 184

Red-gold, $226^{\circ}$

Red-headed Pygmy, 205

Hed Hook-tip, 166

Red-lead, 215

Red Lelter, 188

Red Line Quaker, 59

lied Moth, 44

Red-specked, 209

Red-streaked Knot-horn, 213

Red Triangle, 178

Red 'iwin-spot, 118

Red Underwing. See Wife, 99

Red Wainscot, 88

Reed, 87

Reed Wainscot, 88

Resin Grey, 212

Resinian, 171

Retuse Marble, 167

Reversed C, 94

Iheedian, 168

1 hornboid, 54

Ribbaad Wave, 142

Ribbed Carpet, 119

Rib-striped Snout, 147

Richmond Beauty. See Lilac

Beauty, 107

Ringed China Mark, 151 
Ringlet $\mathbf{3}, 13$ Rivulet, 137 Riveket 13,4 , Rasel's, 206 Rose-leaf Roller, 156 Rose Plume, 231 lose 11 ing, 46 Rosy, 184 liosy $D_{\text {ay }}, 196$ thosy Flounced, 148 iosy Marbled, 97 losy Minor, 72 iosy Rustic, 86 losy Veneer, 215 iosy Wave, 143 fough, 191

iough White, 220 fough Wing, 184 found-tip, i 59

hound Wing, or Round Winged Hiave, 114 ioyal Mantle, 122

liby Fly Hawk, 28 'uby 'Tirer, 43

ti-pennella, 290

fo-cinere'a, 211)

ufous Archi, 169 ufus Brindled, 187 ufous ('arpet, 117 iufous linot-horn, 213 dufous slender, 228 DMLA, 107

Cratagala, ib. 1.unic, 81 Wral Dart, 53 iush Veneer, 151 Usina, 50 ferruginea, ib. usset, 72 ust Brown, 122 Ust Tip, 31 Ustic Mlourner, 72 ustic Shoulder Knot, 71 Usty Button, 175
Rusty China Mark, 153

Rusty Dot, 153

Rusty Minor, 73

Rusty Mitre, 221

îusty Sides, 177

Rusty Triple Spot, 179

Rye Moth, 72

\section{S}

Sable Carpet, 120

Sad, 191

Sad Ash-coloured, 177

Saffron, 158

Saffron 1', (I'ct. Pap.) ises.

Clouded Saffrom, 2

Salicella, 196

Sullow M, (Wrilkes.) Sec

Orange Sallow, 85

Sandy Carpet, 137

Sarnotumisus, 174

Afzeliunus, 175

degeneranus, 174

dilutanus, ib.

Ilicanus, 175

Lathamianus, ib.

ramosanus, ib.

Stonanus, ib.

Satellite, 62

Satin, 41, 215

Satin Carpet, 82

Satin Pug, 132

Satin Pygmy, 205

Satiny Wave, 141

Saturatella, 210

Saturatine, ib.

SAтURNin, 36

Pavonia minor, ib.

Saxon, 66

Scabious F, 6

scabious Long-horn, 195

Scallop IIook Tip, 144

Scallop-winged ()ak MI. See

Dark Heart N], 84 
Searce Black Neck, 98

Scarce Buraished Brass, 94

Scarce Clouded Yellow B, 2

Scarce Copper. See Golden Jod 13, 17

Scarce Dagger. See Goldilock's, 79

Searce Ermine, 197

Scarce IIeath, (Harr.) See Latticed Heath, 139

Scarce Heath. See Marsh Itinglet $\mathbf{B}, 14$

Scarce Knot Grass. See Light Knol Grass, 80

Scarce Magpie. See Clouded Magpie, 124

Scarce Marvel du Jour. See Runic, 18

Scarce Meadow Brown 13. See

Silver Kinglet $\mathbf{B}, 14$

Scarce Meal Moth, 147

Scarce Pearl, 152

Scarce Pug, 134

Scarce P'urple and Gold, 149

Scarce Silver Lines, 155

Scarce Silver $\mathbf{Y}$ M. See Yorkshire $Y, 93$

Scarce Swallow-tail B, I

Sicarce T'issue, 128

Searce Umbre, 103

Scarlet M, 97

Scarlet-barred Gold, 227

Scarlet Jiger, 42

Schallerian, 178

Schaffer's, 206

Schreber's, 201

Schreberian, 158

Scissella, 208

Sicolloped Hazel, 105

Scolloped Oak, ib.

Scollop Shell, 128

scolloped Winged Broad 13ar. See. Scolloped Hazel, 105

Scolloped Winged M. See

Early Thorn, 106

Scopelopes, 98 inops, $i b$.

Scopolian, 169

Scorut. 154

dentalis, $i b$. nebulalis, ib. nivenlis, ib.

Prunalis, ib. sticticalis, ib.

Scorched Blunt-wing, 162

Scorched Carpet, See Clifuen Carpet (Harr. V. ME.), 125

Scorched Wing, See Chip-axe, 116

Scorra, 124.

dealbata, $i b$.

Scotch Argus 13, 19

Scotch Argus B. See Scotch

Ringlet 13, 13

Scotch Pug, 135

Scotch Ringlet $B, 13$

Scotopula, 74

porphyrea, ib.

Scotosta, 127

Rhamnata, ib.

Sparsaria, ib.

Velulata, ib.

Sculker, 54

Sea-Green, 67

Segrta, 60)

neglecta, $i b$.

ranthographa, ib.

Selvedged Blue Argus. See Alexis 13,18

Selvedged IIeath Eyc. See Golden Eye 13, 14

Szamasia, 168

cana, 169

fulvana, ib.

grossana, 168

IIypericana, ib.

lanceolana, ib.

perlepidana, ib.

Pomonella, ib. 
INDEX.

pupillana, 169

Rheediella, 168

rufana, 169

Scopoliana, ib.

splendana, 168

IVaberana, ib.

Somialbella, 210

izmopion, 57

gothica, $i b$.

emi-white Bar, 228

epp's Gold, 227

eptember 'Thorn, 105

erapiim, 132

eraphim, (IIarr). See Sir all

Seraphim, $i b$.

Serratella, 208

\section{SFIIA, 27}

Bombyliformis, ib.

Cimbiciformis, ib.

Fuciformis, $i b$.

SESIID $E, 26$

ETINA, 48

eborina, ib.

roscida, $i b$.

Setinairrorea, ib.

thaded Broad Bar. See Goosefoot, 117

thallow Notchwing; 180

Whark, 90

Mharp-angled Carpet. See

White-Stripe Carpet, 120 Sharp angled P'eacock, 143

Sharp=winged IIawk, 26

Sheers, 68

thepherd's club, 90, 100

Shining, 69

Shining J Jrown, 76

thining C'lay, 208

thining Negro, 44

Shining 1 'itch, 173

Shipton M. See Mask, 101

Shore, 87

Short-barred Carpet. See Ribbed Carpet, 119
Short-barred Grey, 159

Short-barred Straw, 185

Short-barred White, 159, 191

Short Cloak Carpet. See Cloaked

Carpet, 120

Short-cloaked, 154

short-gold $1 \mathrm{ar}, 200$

Short Pैug, 133

Shoulderstripe IVainscot. See

Coinma, 87

Shuttle, 51

Side Spot Triangle, 178

Sieve Lackey, 46

Silken Carpet, 111

Silky, 186

Silver-barred, 96

Silver-barred 13rown, 204

Silver-barred Sable, 149, 207

Silver-blotched, 204

Silver Blotch-back, 162

Silver-bordered TRinglet. (II ut".)

See Silver linglet $\mathrm{B}, 14$

Silver Cloud, 64

Silver Comma.

See Comma B, 8

Silver-dotted, 171

Silver-yround, 118

Silver-hook, 96

Silver Marbled, 172

Silver Ringlet, 14

Silver Spot $F, 7$

Silver-spotted, 182

Silver-spotted Gold, 201

Silver-spotted Sable, 204

Silver sireak F, 8

Silver-streaked, 209

Silver-streaked Hook-tip, 209

Silver-striped, 171

Silver-striped Gold, 227

Silver Studded Blue. See Lead Blue 13, 19

Silver-washed F.(IIarr.) See Silver Streak F, 8

Silver Y. See Gamra, 93 
Silvery Arches, 76

silvery Broad Bar, 182

Silvery IIawk, $20^{\circ}$

SIMAETIIS, 148

Fabriciana, ib.

iulosa, ib.

Myllerana, ib.

pariana, ib.

punctosa, $i b$.

Similanian, 177

Simple, 203

SIMYRA, 89

musculosa, ib.

nervosa, $i b$.

renosa, ib.

Single-barred Rivulet, 138

Single Dot, 203

Single Dotted Woollen, 222 .

Single Stripe Blotch Back, 164 Six-cleft Plume, 231

Six Spot Burnet, 23

Six-stripe Rustic, 49

Slender-bodied 13lack V. See

Black Vau, 113

Slender Gold Tongue, 83

Slender-striped Rufous, 143

Slender Treble Bar, 124

Slight Greenish Half Mourner

13. (Pet. Pap. Var. t.) See Rocket B, 4

Small Argent and Sable, 204

Small Banded, 199

Small Banded Pug, 134

Small Beautiful Pug, 132

Small Black Arch, 154

Small Black F. (Pet. Pap.)

See Scabious k, 6

Small Black Speckled Grey,

190

Small 13lack Spotted, 183

Small Blood Vein, 143

S'mall Blue Border, 138

Small Blue B. (Ilaw.)

Bedford Blue 13,17
Small Brindled Pug, 133

Small-bordered Underwing, 49

Small Brown Bar, 198

Small China Mark, 150

Small Clouded Yellow, See

Barred Yellow, 119

Small Comma. (Pet. Pap.)

See Comma B, 8

Small Dew Lackey, 48

Small Dot or Small Dotted

13uff, 98

Small I otted IVave, 140

Small Double Silver Bar, 204

Small Dusty Wave, 141

Small Egger, 38

Sinall Ermine Knot-horn, 213

Small Fan-foot, 146

Small Ean-footed Wave, 140

Small Fritillary B, (Wilkes.)

See Scabious $k, 6$

Small Garden White B, (IIarr.)

See Turaip B, 3

Small Grass Emerald. See

Grass Emerald, 109

Small Green IIousewife. See

Grass Emerald, $i b$.

Small Grey, 212

Small Grey P'ug, 134

Srnall Heath or Gate Keeper,

(IIarr.) See Golden eye B), 14

Small Ileath B, (Raii.) See Golden Eye 13, 14

Small Ingrailed, 112

Small Lead Argus. See Lead

Blue 13,19

Small Lemon Plume, 230

Small Magpie, 151

Small Mallow M, (IJaw.) See

Goose-foot, 117

Small Marble. See Dwarf Miaf

ble, 97

Small Matron, 42

Small Negro, 44 
INDEX. Small Pearl Border F. See
Silver Spot F,7

imall Plume, 231

imall purple-barred. See Bronze Bar.

Small Raven Feather, 208 small Ringlet, (IIaw.) See July Ringlet, 14

(mall Ringlet, (Ent. Trans.) See Mountain Ringlet B; 13 mall Rivulet, 137

mall Rufous. See Dwarf Red, 98

mall Runic, 221

mall Scollop, 144

mall Seraphim, 132

wall Shining Brown, 210

mall Shuttle, 51

mall Skipper, (IIarr. See Great Streak Skipper B, 21 nall Snout, 146

mall Spotted Brown Marsh Fritillary. See Grizzle B, 20 mall Straw China Mark, 1

mall Straw Yellow Veneer, 217 mail Tabby, 147

mall Tortoise Shell B,(IVilkes.) See Tortoise Shell B, 9 mall Tortoiseshell 13, ( $\mathrm{Pel}$. Mus.-Pet. Pap.) See Copper 3,16

mall IV ainscot. See Red IV ainscot, 88

mall IVaved Umber, 126;

nall White 13, ( Iaw). See

Turnip B, 3

mall White B, (Raii.) See

Wood White 3,4

vall White 13ar, 198

nall IV' hile Garden I3, (Wilkes.)

See Turnip $\mathrm{B}, 3$

malt White Wave, 1399

Nall IVhite Wood B, ( I'ct.I'rp.
Var. o.) : See Wood White 13,4

Small Ycllow Under-wing, (Wilkes.) See Strawberry 'Tree, 95

Small Yellow Under-wing, (IIaw.) See Beautiful, or Beautiful Yellow Under-wing: 95

Small Yellow Wave, 139

Smeathmannian, 184

Smfrintilus, 23

ocellatus, $i b$.

Populi, ib.

Tilice, 24

Smiler, 77

Smoky Arch, 155

Smoky-Grey, 171

Smoky Marble, 168

Smoky Veneer, 219

Sinoky Wainscot, 87

Smoky Wave, 142

Smooth, 110

Smooth Oblique Bar., 156

Snipe, 66

Snout, 145

Snow Short Cloak, 167

Snow White Plume, 230

Snow White Spot, 224

Soap-wott, 69

Solandrian, 173

Solar MI, 96

Sombre, 202

Sooty, 98

Sooty V, (IIaw.) See Black

Vau, I31

Sparmannian, 173

Sparmannian Straw, 188

Spear, 123

Spear Beauty, 125

Spear-point, 79

Speckled 13rown B, 12

Speckled Kinot-hora, 214 
Speckled Pug, 133

Speckled Wood B, 12

Speckled Yellow, 139

Speranza, 101

limbaria, ib. sylvaria, $i b$.

Spectacle, 92

Sphex Hawk, 27

SPHINGID AE, 23

SPHINGINA, 22

SPHINX, 24

Caralina, ib.

Convolvuli, ib.

Drurai, 25

Ligustri, ib.

Pinastri, ib.

plebeia, ib.

poecila, ib.

quinque maculatus, 24.

Sirilonota, 160

aquana, 161

comitana, 162

costipunctana, 16]

Cynosbatella, $i b$.

fonella, ib.

nigricostana

nubiferana, 160

Pfugiana, 161

rusticana, ib.

sticticana, ib.

Stramiana, ib.

tetragonana, 162

trigeminana, 161

trimaculana, ib. ustulana, 162

Sегоosoma, 43

lubricipeda, 44

Menthastri, 43

papyratia, ib.

vadiate, 44

Urtica, 43

Spinach, 123

Spissicornis, 209

Splendid Codling, 168
Sporter, 81

Spotless Brown B, 19

Spotless Hog. See Great

Streak Skjpper B, 21

Spotless Straw, 188

Spotless White, 136

Spotless Yellow, ib.

Spotted Black Plume, 231

Spotted Buff, 44

Spotted Drab, 169

Spotted Ldge, 163

Spotted Elm, 104

Spotted Muslin, 44

Spotted Red, 165

Spotted Rusty Plume, 231

Spotted Sulphur, 96

Spotted Violet, 225

Spotted White Plume, 230

Sprawler, 35

Spring Usher, 102

Sprinkled, 180

Sprinkled Straw, 188

Sprinkled Wainscot, 88

Spurge, 80

Spurge Hawk, 25

Square Bar, 165

Square-barred Single Dot, 164

Square Blotch-Back, 162

Square Spot IRustic, 60

Stained Agate, 124

Starry Brindled, 154

Starwort, 90

Stauropus, 33

Fagi, ib.

Steady Quaker, 58

Steo anolopila, 22

Prunata, $i b$.

STEganorTyCHA, 164

angulana, 165

Baberana, ib.

cinerana, ib.

cuspidana, $i b$. rhombifasciana, ib.

Rubiana, ib. 
stictana, ib.

tetraquetrana, 164

triquetraua, 165

unipunctana, ib.

ileinkelner's, 197

tephensian, 185

iтrLBIs, 98

anomalata, ib.

tomoxys Jlawk, 28

itonanian, 175

flone, 64

'́tout I)art, 54

Itræmian, 161

Straight-barred, 171

Straight-barred EIm, ib.

Stranger, 70

stranger Knot-11orn, 214

Straw-barred, 150

Straw Belle, 116

strawberry Tree, 95

Straw Chinn Mark, 152

Straw Dot, 153

Straw Lackey, 47

Straw May F.(Pet. Pap.) See

Black Crescent F. 6

Sitraw Oblique 13ar, 157

Straw Underwing, 49

Straw Yullow Veneer, 217

Streak, 129

Streaked, 79

Streaked Hutton, 176

Streaked Satin Veneer, 216

Streaked White Shoulder, 220

Streakt Cloudy Hog. See Clouded Skipper B, 21

itreakt Golden Hog. See Great Streak Skipper B, 2]

Streamer, 123

STRENIA, 139

clathrata, ib.

Striped Hawk, 25

Striped Rib, 131

Striped Twin Spot, 118

Sub-angled IVave, 143
Sub Brown Button, 175

Subcinereous, 189

Subcrested, 177

Sub-Fillet, 176

Sublunar Thorn, 107

Subterraneous Rustic, 51

Sub-Triple Spot, 179

Sulphur, 223

Sulphur Pearl, 152

Sulphur Wort Burnet, 231

Sultz's Long Horn, 195

Surrey Ermine, 198

Swallow, 34

Swallow-tail (Wilkes, IIarr.)

See the Queen, 1

Swammerdam's Long-Ilorn, 195

Swan's Feather, 210

Swift Copper B, 17

Swipts, 8

Sword Grass, 65

Sycamore Tussock M, 78

I.

Tabby, 147

T'abby Knot-horn, 214

'I'ailed Buff, 181

Tansy Shark, 90

Tassell, 221

'I'au Emperor, 36

'lawny, 192

Tawny, and Silver M. See

Tawny Silver M, 76

Tawny-barred Angle, 143

Tawny Beauty (Haw.) See

Devon Beauty, 112

lawny Blotch-back, 161

Tawny Crescent, 210

Tawny Crest, 176

Tawny. dotted, 174

Tawny Fillet, 176

Tawny Minor, 72 
INDEX.

Tawny Pinion, 64

Tawny Sheers, 68

Tawny Silver M, 76

'l'awny Speck, 135

lawny Tip, 222

Tawny Treble Bar, 201

Tawny Veined Wainscot. See

Veined Wainscot, 89

Tawny $\mathrm{X}, 71$

Tea Tabby, 147

Teazle. See Marbled Clover, 95

Temple, 76

Ter A, 181

caudana, ib.

'T'essellated, 182

'ETHEA, 83

gracilis, ib.

retusa, ib.

subtusa, ib.

''Heci $A, 14$

Betula, ib.

Pruni, 15

Quercus, ib.

Inubi, 16

Spini, 15

T. W. Album, ib.

TIIERA, 130

fulvata, ib.

Juniperata, $i b$.

simulata, ib.

variata, ib.

Thick-horned Green, 209

Thistle Ermine, 215

Thistle Straw, 188

'Three Corners, 100

'Three Spotted, 55

Three Streaked, 211

'Tiyatra, 81

batis, ib.

derasa, ib.

Tirmele, 20

alvcolus, ib.

malve, ib.

Oileus, il.

Tages, 20

Thusberg's, 194, 228

Timanna 113

emutaria, ib.

imitaria, ib

subroseata, ib.

variegata, ib.

Linctella, 193

TINEA, 222

albipunctella, ib.

cloacella, 223

Desiructor, ib.

flavescentella, 222

fuscipunctella, ib.

granella, 223

Lappella, 2:2

nigripunctella, ib.

parasitella, 223

pellionella, 222

semifulvella, $i b$.

sulphurella, 223

tapetrella, 222

vestianella? ib.

ustella, 223

TINEID E, 211

Tinted, 193

Tinted Grey, $i b$.

Tiny Quaker, 58

Tissue M, 128

Toad-flax, 9 l

Tobacco Ilawk, 24

Tooth-streaked Hook tip, 219

Tooth-striped, 131

Tooth-striped Wave, 141

Torchlet, 166

Tortoise Shell B, 9

Tortricella, 196

TORTRYCID $A, 155$

TORTRICINA, ib.

Tontas, ib.

clorana, ib.

Iavana, ib.

Pillerana, ib.

unitana, ib. 
viridana, ib. RACHEA, 74

Alriplicis, ib. ransparent China Mark, 151 ransparent Negro, 45 raunian, 163 ieble-atom, 210 reble Gold Stripe, 201 teble-spotted, 224 reble Twin Spot, 140 refoil 13urnet, 22 refoil Green, 209 rembler, 36 riangle, 55,164 iriangle Plume, 230

Triangle marked Purple, 228 Inangle marked Red, ib. riatomea, 210

l'Richivita, 37

Cratagi, ib. íricoloured, 191 iricoloured Green, 179 Iricomma, 55

Prifolii, 209

rigeminian, 161

drigonian, 178

lrimmer, 163

TRIPIANA, 48

Fimbria, 49

Interjecta, ib.

Innuba, ib.

Janthina, ib.

orbona, 48

Pronuba, 49

Subsequa, 48

Hromosa, 128

corvinata, ib.

cincreata, ib.

dubitata, ib.

lipple 13arisl, 99

friple Blotched, i6l

Iriple Gold Spot, 203

riple Line Mosha, 115
Triple Lines, 60

Triple Spot Burnet, 23

Triple-spotted Black, 225

Triple-spotted Buff, 222

Triple-spotted White, 225

Triple-spotted Yellow, 222

Triple Stripe Blotch-Back, 164

T'rocustrum, 27

Apiformis, $i b$.

Crabroniformis, ib.

True Lover's Knot. See Porpliyry, 74

Tunbridge Grayling. See Grayling 13, 12

T'urf Rustic, 50

Turkey's Feather, 227

'Turnip B, 3

Twin Band, 198

T'win-barred Knot-horn, 213

Twin Lobe, 72

I'win Point, 3 I

Twin Point Carpet, 82

Twin Shark, 91

Twin-spot Carpet, 117

I'win-spot 1) rab, 57

Twin-spot Ermine, 197

I'win-spot Pinion, 84

Twin-spot Sable, 204

$\left.\begin{array}{l}\text { Twin-spot } \\ \text { T'win-spotted }\end{array}\right\}$ Wainscot, 88

Twin Streak, 172

T'win-striped P'inion, (IIaw.)

See Striped Rib, 131

Twin-stripe, or ? Wave, 114

Twin-tailed Shark. See Twin. shark, 91

Two-spotted Black, 224

Two-spotted Brown, 224

U.

Udmanian, 173 
Umbre, 103

Umbre Link, 103

Unicorn Hawk, 24

United, 100

Unitella, 193

Upsilon, 59
V. Pug, 132

VALERIA, 74

oleagina, ib.

VANESSA, 8

Antiopa, 9

Io, ib.

Polychloros, ib.

Urice, ib.

Vapoures, 41

Variable Autumn, 220

Variegated Hawk, 25

Variegated Pearl, 151

Variatle Red, 166

Variable Ribband Wave, 142

Variable Swift, 29

Veined Dart, 52

Veined Waistcoat, 89

VENILIA, 139

macularia, ib.

quadrimaculata, ib.

Veinous, 186

Vernoun's Greenish Ilalf Mourner. (P'et. Pap, Var. ㅇ․) See Rocket 13, 4

Vernoun's Small Fritillary, ( $\boldsymbol{P}$ et.

Gaz.) See Duke F, 5

Vesper Beauty, 115

Viburnian, 157

Violaceous Slender, 229

Violet Pygmy, 205

Virgin, 49, 100

Vulture Feather, 208
IV.

IVainscrt M. See Smoky IVainscot, 87

Wainscot Flat Body, 187

Wainscot Hook-tip, 219

Wainscot T'ortrix, 211

Wainscot Veneer, 219

Wall 13,12

Wall carpet, 111

IVall Usher, 102

Walkerian, 158

Warted Knot-horn, 213

Water Betony, 89

Water Betony likeness. See Water Betony MI, 90

Water Betony Sword Grass, See Mullein M, 90

Water Carpet, 122

Water Ermine, 43

Waved, 147

Waved Black, 101

Waved Carpet, 139

Waved 1Rustic, 61

Waved Umbre, 112

Wared Wainscol, 88

Wavy-barred Sable, 149

Wavy Drab, 170

Wedge 13ar, 52

Wedge Pearl Border. See Silver Spot F, 7

Welted Beauty, 112

Wheat 1)art, 52

White Admirable, (IIarr.) See Honeysuckle $\mathbf{B}, 11$

White Admiral B, (Pet. Pap.) See Honeysuckle B, 11

White $\mathrm{B}$, with green veins,

(IVilkes). Sce Navew B, 3

White-back, 199

White-Backed, 160

White-backed Black, 22? 
Thite 13rindled, 154

l'hite Border, 138

Phite-bordered, 194

ilite Bordered B,

See Willow 13, 9

thite Butterfly with black veins

(Albin). See Hawthorn B, 5

ihite Button, 176

ihite Colon, 70

ihite Dot, 176

Ihite Dotted Black, 191

Thite Dullidge F. See Glanville $\mathrm{F}, 6$

Thitc-edged, 209

Phite Fillet, 176

Thite-foot, 161

Phite-fringe, 181

Phitc Girdle, 115

Thite Letter, 73

White line, 53

"hiie-line Black, 70

i'hite-line Snout, 147

White-lined Jlack. See IV'hite Girdle, 115

White Marbled B, (Raii.) See Wood Lady B, 4

White Marbled Female B, (Pet.

Pap. Var, o). See (Vood

Lady 13, 4

thite Marbled Male 13, (Pet. Pap. Var. §). See Wood Lady 13, 4

Vhite May F. (Pet.Pap.) Sce

Yellow Crescent F, 6

thite Pinion spotted, 136

Thite Satin Veneer, 216

thite-shafted Plume, 230

White Shouldered, 178, 220

Fhite Shouldered IVoollen, 190

White Sides, 177

White Slender, 229

thite small tipt B, (Pel. Pap. Var. $\delta)$. See Wood IVhite
White Speck, 89

Wh hite-speckled Black, 222, 226

White Short Cloak, 167

White Spot, 56, 144, 148

IV hite Spot Bright Eiye, 60

White Spot Brown. See Scotch Argus B, 19

White Spot Cornnel, 75

White Spot, or ? Pinion, 84

White Spotted

White Spot Sheers, 68

White Spotted Black, 192

White Spotted Brown, 207

White Spotted Sable, 203

White Streak, 208

White Stripe, (Wilkes.) See Sable Carpet, 120

White Stripe Carpet, 120

White 'Triple Spot, 179

White Wave, 113

White Waved Gothic, 69

Whittlesea Ermine, 41

IVidower, 110

IVife, 99

Wild Arrach M. See Orrach, 74

Wild Carpet, 121

IVillow 13, 9

Willow Beauty, 111

Willow Red Underwing. Šee IVife, 99

Winter, is4

Wiater Beauty, 103

Woeberian, 168

Wood Carpet, 120

Wood Lady 13, 4

Woodland, 101

Wood Leopard, 30

Wood Skipper B, 2 I

Wool 'Tiger, 43

Wood White 13,4

Wormwood M, 91

Wormwood Eyelet, 169

Vormwood 2'ug, 134 
$x$.

$\mathrm{X}_{\text {А }}$ тита, 85

aurago, ib. centrago, ib. citrago, ib. croceago, $i b$. fimbriago ib. flavago, ib. fulvago, ib. gilvago, ib. rufina, 86

Xanthoset1A, 185 diversana, ib. ferrugana, ib. hamana, ib. inopiana, ib. Zagana, ib.

XERENE, 125

adustata, ib. albicillata, ib. plumbala, ib. procellata, ib. rubiginata, ib.

XYบinA, 64 conspicillaris, $i b$. Lambda, ib. perspicillaris, 65 petrificata, 64 pulla, ib. putris, 65 semibrunnea, 64

Xylophasia, 65 combusta, 66 epomidion, ib. hirticornis, ib. lithoxylea, 65 polyodon, ib. rectilinea, 66 rurea, ib. Scolopacina, ib. sublustris, 65
$Y$.

Yeates's Straw, 188

Yellow, or Brimstone, (IIarr.) See Brimstone, 107

Yellow-barr'd lron, 174

Yellow Belle, 116

Yellow Border, 137

Yellow-brindled Bar, 131

Yellow Crescent F, 6

Yellow Dotled, 225

Yellow Drab, 170

Yellow Dwarf, 183

Yellow-fringed WVite, 221

Yellow Girdle, 77

Yellow Head, 210

Yellow-lseaded Black, 208

Yellow horned, 83

Yellow Line, 59

Yellow masbled Carpet. See Comma Carpet, 221

Y. Moth. See Gamma M, 93

Xellow Purple Bar, 116

Yellow Satin Veneer, 216

Yellow Shell, 128

Yellow Shoulder Stuipe. See Yellow Shell, 126

Yellow Spot Unicorn Irawk, 24

Yellow-stigmaed Grey, 211

Yellow-striped edge, 168

Yellow T'ussock, 40

Yellow V, 227

Yellow Veneer, 218

Yorkshire $Y, 93$

Yorkshire $Y_{,}($Don $)$. See Essex $Y, 94$

Y PONOBELTA, 197

albistria, 199

ambiguella, 198

bifasciella, ib. Ceriella, 199

Clematella, 200 comptella, 198

Cratagella, ib. 
Curtisella, ib. curvella, 199, Evonymella, 197 irvorella, 198 leucatella, ib. lutarella, ib. mendicella, 199 ocellea, ib. ossea, ib. padella, 198 plumbella, ib. Pruniella, 199 rorella, 198 semifusca, 199 subfasciella, ib. subocellea, ib. tetrapodella, ib. THONOMEUTIDAE, 186 insolopues, 220 costellus, ib. crmineus, ib. fissellus, 221 faviciliatus, ib.
IIesperidellus, 221 lutosus, ib. maurellus, ib. mueronellus, 220 ochroleucus, ib. Persicellus, ib. quinquepunctatus, ib. radialellus, 221 rufimilrellus, ib. sequellus, ib. variellus, 220 viliellus, 221 ustulatus, 220 Xylostella, 221

Z.

Zevzera, 30 Asculi, ib. Zogian, 185 $Z Y G A N I D A, 22$. 





